\title{
People's Perceptions of Community Participation in Conservation of Natural Resources in Rwanda - the Case of Nyungwe National Park
}

\author{
Inaugural-Dissertation \\ Faculty of Humanities \\ of the University of Bamberg
}

written by

Gloriose Umuziranenge

(born on 7.1.1984 in Rwamagana-Kigabiro-Rwanda)

Bamberg, 15 / 10 / 2020 
Dieses Werk ist als freie Onlineversion über das Forschungsinformationssystem (FIS; https://fis.uni-bamberg.de) der Universität Bamberg erreichbar. Das

Werk steht unter der CC-Lizenz CC-BY-NC-ND.

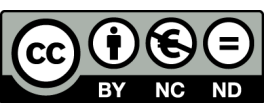

URN: urn:nbn:de:bvb:473-irb-499638

DOI: https://doi.org/10.20378/irb-49963

Day of the oral examination:

February, 15th 2021

Dean:

Prof. Dr. Markus Behmer

First supervisor:

Prof. Dr. Marc Redepenning

Second supervisor:

Prof. Dr. Annette Scheunpflug 


\section{Acknowledgement}

Since I was very young, it was my dream to have a PhD. In the process of getting a PhD degree, I produced 5 papers and a synopsis.

Deep thanks go to my awesome supervisors. I thank Professor Dr. Marc Redepenning for all his wisdom, advice, and tireless continuous support throughout my $\mathrm{PhD}$ research. His encouragement, guidance, and support from the initial level to the final level of this research enabled me to develop an understanding of the subject.

With plenty of joy I would like to extend my thanks to Prof. Dr. Annette Scheunpflug for guiding me up the stairs to join the academic community. She has assisted me at the very beginning stage of this journey by connecting me with my supervisor. During difficult moments, she never forgot to assist me, and she was always rejoicing with me through all of the moments of this achievement. I am deeply grateful for the professional input given to me throughout my $\mathrm{PhD}$ project, the time and effort to produce the second report as a second supervisor and for the pleasant moments shared in different PhD seminars.

I thank Dr. Sebastian Scholl for his encouragement and insightful comments throughout my PhD project.

I would like to acknowledge the optimistic ideas and interesting talks and discussions with my PhD learning community both at Bamberg University and at the Protestant University of Rwanda. I present my deep gratitude to Bread for the World via the Protestant University of Rwanda for sponsoring my doctoral studies through a bursary. I owe my deepest gratitude to Bread for the World scholarship desk and Protestant University of Rwanda for all kinds of support that was provided for the success of this project.

I am grateful to express my sincere appreciation to the Rwanda Development Board for the facilitation and permission to conduct this research in Nyungwe National Park. By this I thank my colleagues in Rwanda Development Board and Wildlife Conservation Society for their support.

Heartfelt thanks go to my husband Daton Eric and my lovely daughter Daton Alleja. They pushed me to work hard and supported me with their unfailing love and ideas which have made my days bright. I would like to thank my sisters Claire, Clarisse, Alexia, Donatha, Nadine who were always there, pushing me hard to go far. Last but not least, I thank my parents, Kagabo Alexis and Kayirere Odette for their determined efforts to get me educated during my childhood. I am deeply thankful to all of you.

Gloriose Umuziranenge

Otto-Friedrich University of Bamberg 


\section{DEDICATION}

I dedicate this PhD to my husband Daton Eric Ngilinshuti and our lovely daughter Daton Alleja Ngilinshuti. 


\section{TABLE OF CONTENTS}

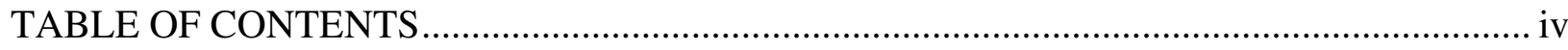

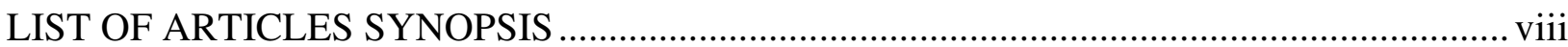

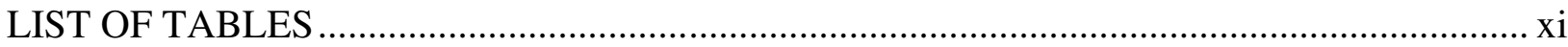

LIST OF FIGURES ......................................................................................................

LIST OF ACCRONYMS AND ABBREVIATIONS ..............................................................ii

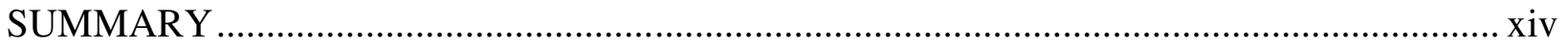

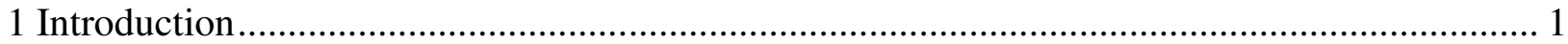

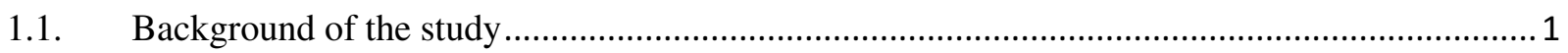

1.2. Problem statement ....................................................................................................

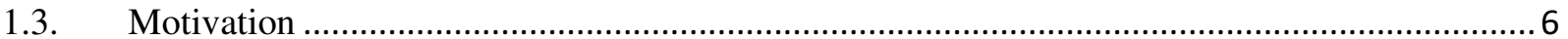

1.4. Description of the case study of Nyungwe National Park .......................................................

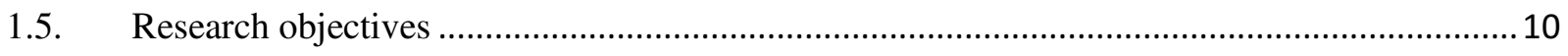

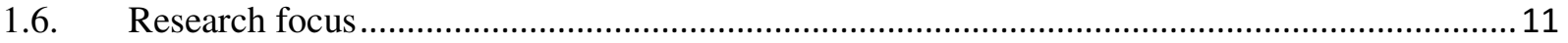

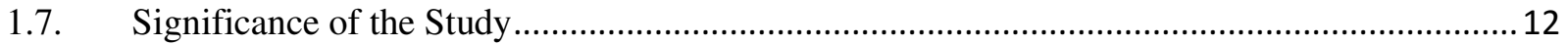

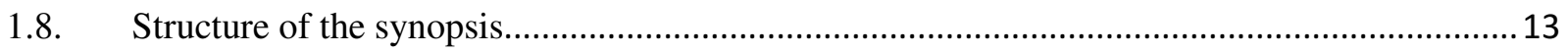

2. Literature Review and Conceptual Framework .............................................................. 14

2.1. Governance, Democracy and Community Participation ........................................................ 14

2.2. Social justice and community empowerment .......................................................................

2.3. Ecotourism and empowerment of local community around protected areas.............................2. 24

2.4. Human and wildlife conflicts around protected areas ..........................................................2 29

2.5. Conservation practices and challenges in Rwanda................................................................ 31

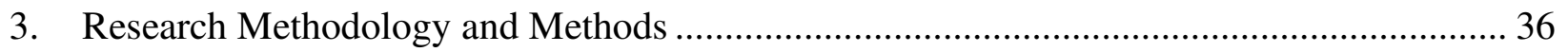

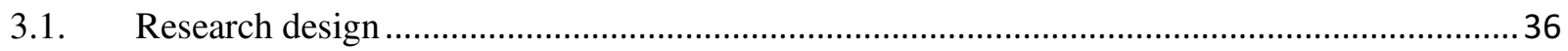

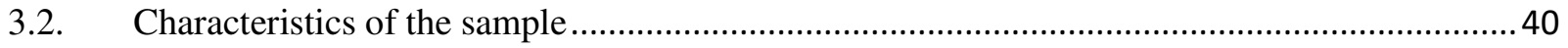

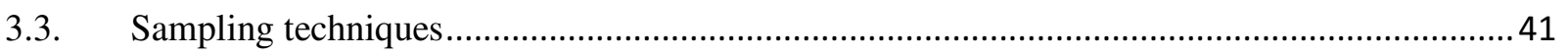

3.4. Data selection methods ……………………………….................................................... 43

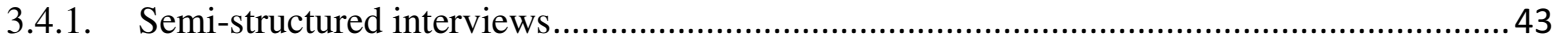

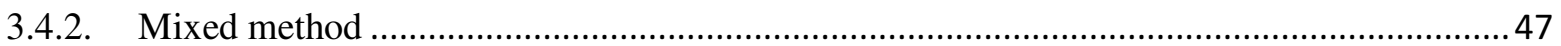

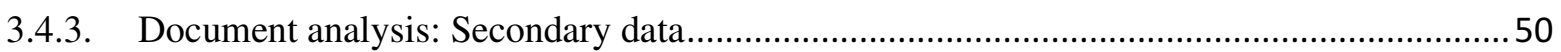

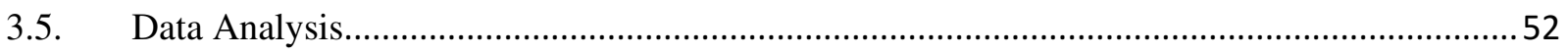

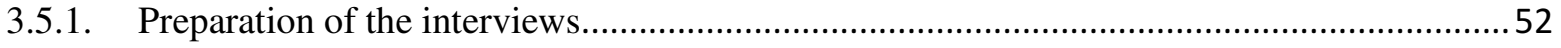


3.5.2. Data Analysis: Coding and Categorization

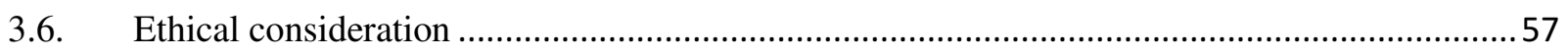

3.7. Ensuring the Quality in the Research Process …........................................................... 58

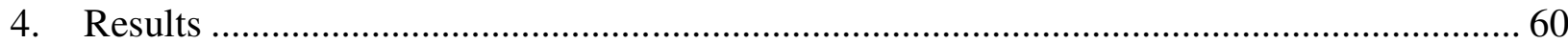

Paper 1: Parks' Governance and Management in Rwanda: Opportunities and Challenges of the Community Participation for a Sustainable Conservation ................................................................62

Paper 2: Environmental Justice and Women Empowerment ......................................................... 62

Paper 3: Ecotourism and its Impact on Community Development around Nyungwe National Park (NNP) 63

Paper 4: Community Perceptions of Human-wildlife Conflicts and the Compensation Scheme ...........64

Paper 5: Nature of conservation policies and practices in Africa .................................................... 65

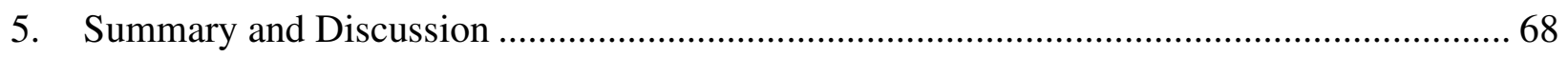

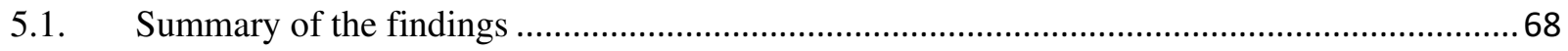

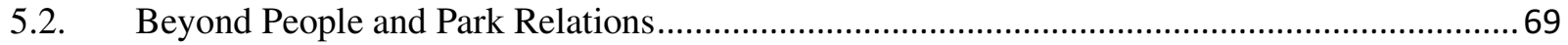

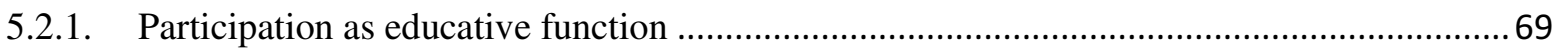

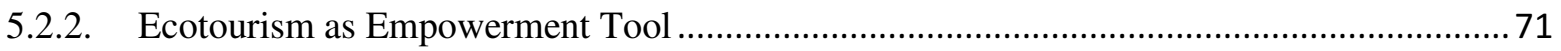

5.2.3. Participation as integrative function.............................................................................. 72

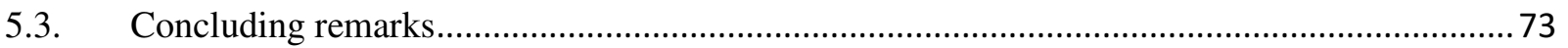

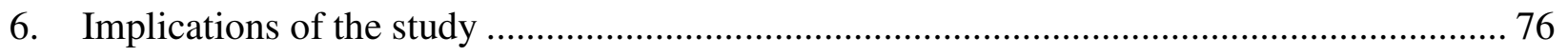

6.1. Implications of the study for the policy makers, NGOs, and local communities ..................... 76

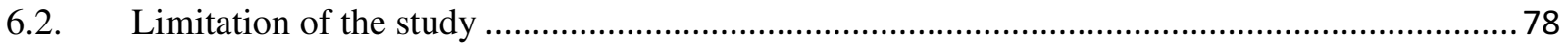

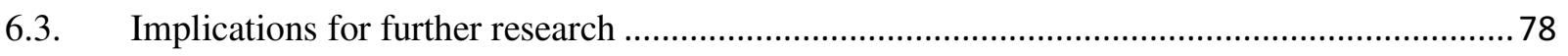

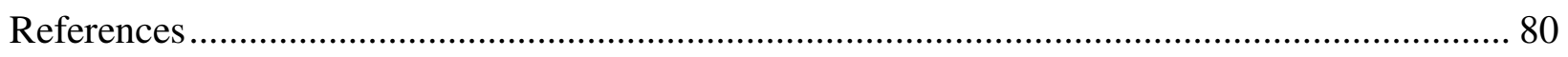

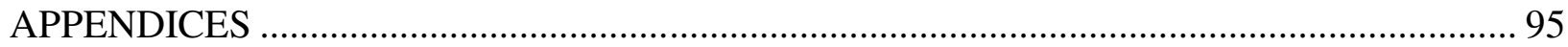

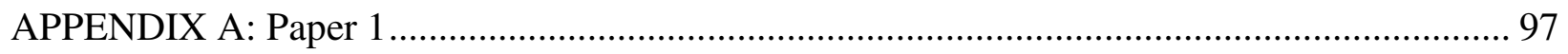

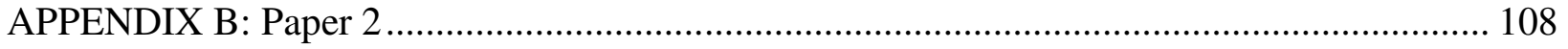

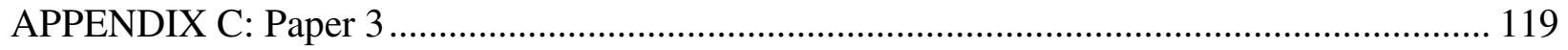

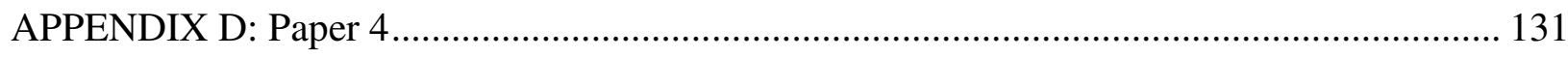

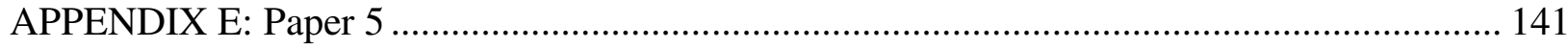

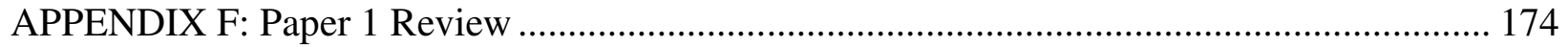

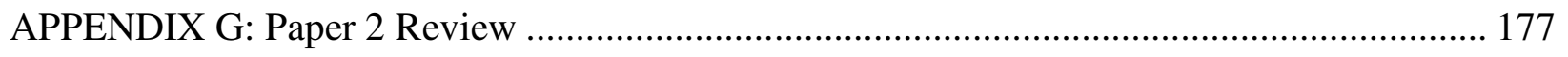

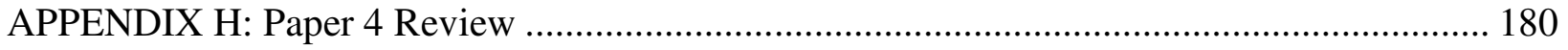

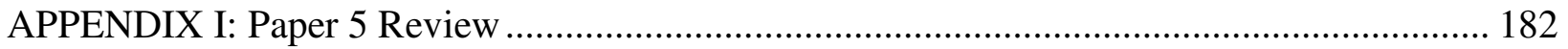


APPENDIX J: Conference Participation ....................................................................... 183

APPENDIX K: Research Permit .................................................................................... 186 


\section{LIST OF ARTICLES SYNOPSIS}

This synopsis is based on and reflects upon the following papers:

\section{Paper 1:}

Umuziranenge, G. (2019). Parks' Governance and Management in Rwanda: Opportunities and Challenges of the Community Participation for a Sustainable Conservation: Case Study of Nyungwe National Park. International Journal of Environmental Protection and Policy, 7(2), 6171; DOI: 10.11648/j.ijepp.20190702.13. Papers published in this journal are widely spread and indexed by lots of famous databases, such as WorldCat, CrossRef, DRJI and so on. Information regarding the indexing of this journal can be found on:

http://www.sciencepublishinggroup.com/journal/indexing?journalid=266 . As to the peer-review process, this journal uses double-blind peer review. Information about reviewers can be found on: http://sciencepg.com/journal/peerreviewers?journalid=266 . The review results of this paper are attached on appendix F.

\section{Paper 2:}

a) Umuziranenge, G. (2019). Environmental Justice and Women Empowerment in Nyungwe National Park (Rwanda): Case Study of Kitabi Women Handcrafts Cooperative. International Journal of Environment and Climate Change, 77-87; DOI: 10.9734/IJECC/2019/v9i230098. Information regarding the indexing of this journal can be found on: https://www.journalijecc.com/index.php/IJECC/abstracting-indexing (NAAS score: 5.29). As to the peer-review process, this journal uses an advanced open review system. Information about the review process can be found on: http://www.sdiarticle3.com/review-history/48394. The review results of this paper are attached on appendix G.

b) Umuziranenge, G. (2019). Environmental justice and women empowerment in the protected areas of Nyungwe National Park: Case of women handcrafts cooperative. ASC-TUFS Working Papers 2018 Development, Migration, and Resources in Africa, 143-160.

c) Umuziranenge, G. (2019). Community empowerment and Environmental Justice in Rwanda. Ethics for Life, 180-194.

\section{Paper 3:}

Umuziranenge, G., Muhirwa, F. (2017). Ecotourism as potential conservation incentive and its impact on community development around Nyungwe National Park. Imperial Journal of Interdisciplinary Research. Vol-3, Issue-10. 447-456; available at https://www.researchgate.net/publication/324780299. The review process was a blind review system. 


\section{Paper 4:}

Umuziranenge, G. (2019). Community Perceptions of Human-wildlife Conflicts and the Compensation Scheme around Nyungwe National Park (Rwanda). International Journal of Natural Resource Ecology and Management, 4(6); 185-217, DOI: 10.11648/j.ijnrem.20190406.15. Papers published in this journal are widely spread and indexed by lots of famous databases, such as WorldCat, CrossRef, DRJI and so on. Information regarding the indexing of this journal can be found on:

http://www.sciencepublishinggroup.com/journal/indexing?journalid=207. As to the peer-review process, this journal uses double-blind peer review. Information about reviewers can be found on: http://www.sciencepublishinggroup.com/journal/peerreviewers?journalid=207. The review results of this paper are attached on appendix $\mathrm{H}$.

\section{Paper 5:}

Umuziranenge, G., Ntiranyibagira, E., (2019): Nature conservation policies and practices in Africa: Critical analysis, ideological challenges, and strategic vision for protected areas sustainable management. Available at http://www.tufs.ac.jp/asc/185-217Umuziranenge.pdf ASC-TUFS Working Papers 2019 Challenges of Development and Natural Resources Governance in Africa: 185-217: ISBN 978-9910084-2-9. The review process was an open review and results are attached on appendix I. 


\section{Contribution}

\begin{tabular}{|l|l|l|l|l|l|}
\hline \% of my contribution & Paper 1 & Paper 2 & Paper 3 & Paper 4 & Paper 5 \\
\hline Concept and idea & $100 \%$ & $100 \%$ & $100 \%$ & $100 \%$ & $75 \%$ \\
\hline Study design and methods & $100 \%$ & $100 \%$ & $100 \%$ & $100 \%$ & $75 \%$ \\
\hline $\begin{array}{l}\text { Data gathering and } \\
\text { Interpretation }\end{array}$ & $100 \%$ & $100 \%$ & $65 \%$ & $100 \%$ & $75 \%$ \\
\hline Manuscript preparation & $100 \%$ & $100 \%$ & $100 \%$ & $100 \%$ & $100 \%$ \\
\hline
\end{tabular}

Table 1: Contribution 


\section{LIST OF TABLES}

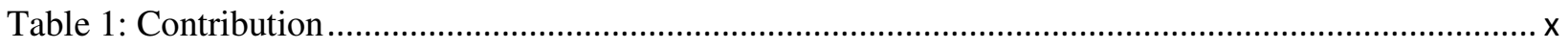

Table 2: Views on governance, democracy, and community participation ........................................... 17

Table 3: Summary of research methods according to the papers and category of respondents.................. 39

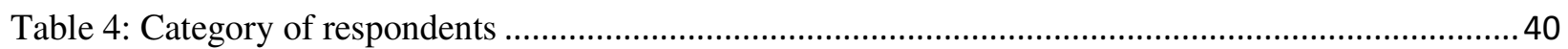

Table 5: Characteristics of respondents (data base, used for paper 1, 2 and 4) ..................................... 42

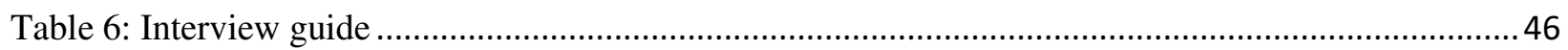

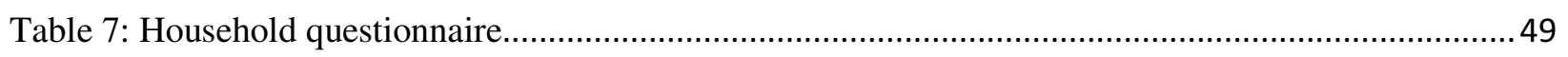

Table 8: Category and number of documents used for document analysis method in paper 5.................50

Table 9: Illustration of themes and memos for secondary data analysis................................................51

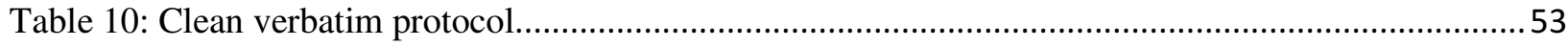

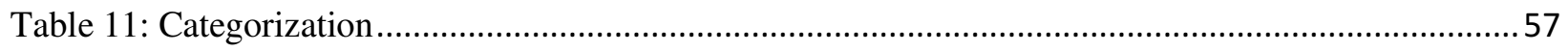

Table 12: Illustration of the papers, research questions and key findings ..............................................61 


\section{LIST OF FIGURES}

Figure 1: Map of Rwanda with 4 National Parks................................................................................ 7

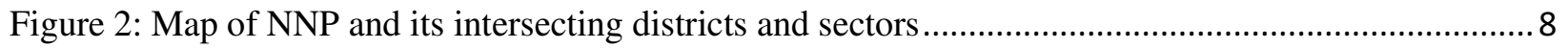

Figure 3: Research framework of this study ................................................................................ 11

Figure 4: Relationship between environment justice, community empowerment, and natural resources

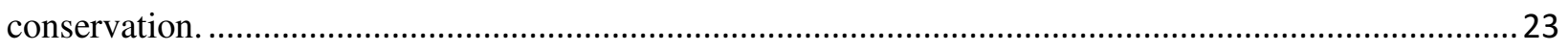

Figure 5: Link between Ecotourism and local community's empowerment ..........................................28

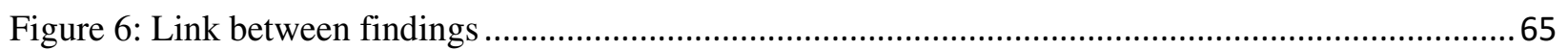




\section{LIST OF ACCRONYMS AND ABBREVIATIONS}

ASC-TUFS: African Studies Center- Tokyo University of Foreign Studies

EICV: Integrated Household Living Conditions Survey (Enquête Intégrale sur les Conditions de Vie des Ménages)

FAO: Food and Agriculture Organization

GDP: Gross Domestic Product

GoR: Government of Rwanda

HWC: Human Wildlife Conflicts

IJECC: International Journal of Environment and Climate Change

NISR: National Institutes Statistics of Rwanda

NNP: Nyungwe National Park

ORTPN: Rwanda Office of Tourism and National Park

PAs: Protected Areas

RDB: Rwanda Development Board

REMA: Rwanda Environmental Management Authority

RWF: Rwandan Franc

TRS: Tourism Revenue Sharing

WCS: Wildlife Conservation Society 


\section{SUMMARY}

Overall, there have been numerous activities to implement local community participation approaches in the protection of biological diversity and natural resources in general. Eco-centric or protectionism approach that is focusing on reducing human interactions on ecosystems is important for positive ecological outcomes of protected areas. However, it has indicated that conservation initiatives and programs that rely on rejection of local community' participation and strict enforcement are not achieving the expected outcomes and local community's expectations. It is against this background that the government of Rwanda in 2005 adopted a decentralized governance system in park's management through tourism revenue sharing (ORTPN, 2005). In this thesis I assess whether and how the local communities participate in the daily activities regarding the park's management through implementation of tourism revenue sharing and how it impacted local communities' participation in conservation of Nyungwe National Park as well as the promotion of their well-being. The main research question of my thesis is the following: How do people perceive local community participation in natural resources management?

This main research question is specified by the following sub question:

- How do local communities participate, and perceive their role in the conservation of the park?

- What are the benefits and opportunities do they get as neighbors of the Park through TRS?

- How do they participate in decision-making process?

- What are challenges do they face being neighbors of the park?

- What do local communities wish to minimize the challenges they face?

The thesis is organized as a paper-based thesis, being published in different scientific journals and in some cases additionally linked to presentations in international conferences. Included here are five papers that shed light on the research questions.

In Paper 1, I assess how local community participates in the conservation of the park, the benefits and opportunities that the local community gets as neighbors of the Park, how they participate in decision making process. I assess the challenges that the local community faces in the process of conservation of the park and I propose strategies for the future management of the park.

Paper 2 consists of three publications that focus on community participation and environmental justice. The first and the second publications under this paper specifically focused on women as 
important group in the community and in the conservation of natural resources. Therefore, I assess how women understand their role and participation in the conservation of the park. I describe how they benefit and which kinds of opportunities they get as women. I assess how women are empowered and I discuss challenges they face as women. The results were reviewed and published by IJECC and ASC-TUFS working papers under the project" Development, Migration and Resources in Africa." The third publication provide an extensive understanding of the link between community empowerment and environmental justice for the book chapter " Ethics for life of Bread for the World".

In Paper 3, I specifically assess how ecotourism plays a role in empowering the local community who live adjacent to the park. I discuss how and in which extend ecotourism serves as an incentive for the conservation of the park.

In Paper 4, I assess how the local community perceives human-wildlife conflicts especially crop raiding and how they perceive the compensation scheme initiated to alleviate tensions between them and the park management.

In Paper 5, I analyze existing practices and policies in the management of protected areas especially in Sub Saharan Africa.

In the process of the research process, I used different methodologies according to the aim of each paper. Therefore, in Paper 1, 2 and 4, I adopted a qualitative approach with semi-structured interviews while in Paper 3, I adopted a mixed approach based on a survey and interviews with key respondents. In Paper 5, I used secondary data (document analysis) from existing policies and practices for natural resources conservation, especially in Africa.

The findings show that the Park's management has improved the relationship between the local community and Park by accommodating local needs such as infrastructures (schools, health centers, communal water tanks) income generating activities, increased awareness in terms of park's protection through a tourism revenue sharing scheme that was introduced since 2005 ( refer to Paper 1, 2, and 3). The local communities living near the protected areas appreciate the idea of infrastructure development. However, the direct benefit to individual families remains a challenge due to the fact that the funding goes to support the projects planned by the districts including housing, education, and health infrastructures. 
This supports the district to perform well in imihigo ${ }^{1}$. Therefore, the local inhabitants judge this strategy as aiming at helping the local government (districts) to achieve their performances (imihigo) rather than supporting individual family neighboring the park (Paper 1 and 2). According to the perceptions of the respondents in this study the governance of the park is still dominated by a top-down approach through a distant representative democracy where the participation of the local community remains only passive (Paper 1, 2 and 3). The conservation policy and practice (Paper 1, 2, 3, and 4) clearly show the impact of protected areas on people's well-being and the role of the local community that reduce threats to the Park. Among the challenges that the local community faces, I can highlight the challenge related to the top down model that is perpetuated by the dominance of the Rwandan Development Board (RDB) in the definition and implementation of policies without participation of the representatives of the communities. Local authorities are informed of the budget allocated to the district and invited to present projects for funding, and then supervise the elaboration and implementation of the projects. The community members are almost absent in the monitoring and evaluation processes. In the annual management meeting, not only the population is not represented, even the district is not well informed who the RDB invites in the meeting and on which basis. Active participation was claimed by the local community (Paper 1, 2, 3, and 4).

Another challenge is related to human-wildlife conflicts (see Paper 4). The findings in Paper 4 indicate that, collective guiding systems, fair compensations and a fence of the park could be useful tools in minimizing tensions between the population and wild animals.

All papers suggest that more attention should be dedicated on participation as an integrative and learning process where the local community should be empowered. Through increased knowledge and skills these processes would contribute to enabling processes to become citizens who are able to influence and improve political decisions (Paper 1, 2, 3, 4, and 5).

Keywords: conservation, governance, local community participation, protected areas.

\footnotetext{
${ }^{1}$ Imihigo is a cultural practice in the ancient tradition of Rwanda which an individual set himself targets to be achieved within a specific period of time. The concept now is being used as a central aspect when analyzing the political economy of the country. Imihigo introduces a results orientation between two domestic entities, the national and sub-national government entity, in form of annual performance contracts between the President of the Republic and the district mayors.
} 


\section{Introduction $^{2}$}

This study concerns community participation in conservation of natural resources in Rwanda with the case of the Nyungwe National Park. Specifically, the focus is people's perceptions of community participation in natural resources management with the case of Nyungwe National Park. This chapter introduces the study in eight parts: First, the background of the study will be described (1.1), secondly an overview on the related problems will be given (1.2). Thirdly, I will mention my motivation to work on this case (1.3). I will describe the case of Nyungwe National Park (1.4.). By reflecting the lack of research in the field, the objectives of the study (1.5) and its research focus (1.6) will be elaborated. The significance of the study will be reflected (1.7) and an overview about the structure of this synopsis will be given (1.8).

\subsection{Background of the study}

Conservation approaches started with "fortress conservation" that exclude the local populations from the use of natural resources and does not share power with local communities or local institutions (Brockington, 2002; Doolittle, 2007; Peluso, 1992, 1993; Scherl et al., 2004; Siurua, 2006). As indicated by Adams and Infield (2003) protectionism approaches denied local communities to take an interest in conservation activities. The local population had no advantages and rights to use their own resources for their basic needs. For a long-lasting period, this approach was seen as the best way to accomplish conservation of natural resources. This approach considered humans as consumers and denied citizens' power over decisions that directly or indirectly affect their lives (Jones, 2006; Miller et al., 2011; Western, Wright \& Strum, 1994). With this approach protected areas were considered as the best areas for conservation. The protected area was delimited and placed under state control where human impact was monitored, and local people were excluded from the use of natural resources.

In Sub Saharan Africa (SSA) specifically, the creation of protected areas focused on natural areas of high tourist interest by targeting strategic hunting areas and endemic species. Wild animals had become things to think about for rich urban populations rather than things to eat for poor local people (Colchester, 2003; Huxley, 1961; Myers et al., 2000; Triplet, 2009).

\footnotetext{
${ }^{2}$ This chapter refers mainly to Paper 5 .
} 
In addition, protectionism approach considered local people as ignorant destructors against whom nature should be protected. This perception of the population became a source of conflicts and injustice in SSA where this concept of protected area has expanded quickly and local livelihood strategies like hunting and encroachment were declared as illegal activities (Adams \& Hutton, 2007; Mugisha, 2002; Pemunta, 2019; Robbins, 2004).

In the 1980's-1990's, that old conservation approach was replaced by a new conservation approaches known as "integrated conservation and development (ICD) that aims to link conservation outcomes with development impacts in response to the widespread failures of fortress conservation and the growing trends within development policy towards local participation and stakeholder involvement" (Blomley et al., 2010, p.1). With this approach the image of conservation in Africa has shifted from wildlife protection which denies local communities to a people-oriented conservation. This people-oriented conservation respected - at least in the conceptions - the needs of the population. By this, principles had been implemented that conservation should be community-based to achieve community development where protected areas represent multiple and important interests for different actors involved in the management of natural resources (Adams et al., 2004; Colchester, 2003; Giraut et al., 2004; Kaboré, 2010; Kasisi, 2012; Mahonge, 2010; Otto et al., 2013; Scholte, 2010).

As indicated by numerous studies, among integrated conservation and development approaches, sharing tourism benefits has consistently been considered as one of the different methodologies of community participation in natural resources conservation (Adams \& Hulme, 2001; Archabald \& Naughton-Treves, 2001; Cole, 2006; Li, 2004, 2005; Timothy, 1999; Tosun, 2000; Zacarias \& Loyola, 2017). Tourism revenue sharing (TRS) programs aims to promote tourism development and ensuring for local communities' tangible benefits while participating in wildlife conservation. This concept is considered as a way of reconciling conservation and development by ensuring that the interests and knowledge of local communities are considered. Community involvement in tourism development should not only lead to getting local communities' support in conservation initiatives but should also act as a crucial component to achieve sustainable development of the tourism industry. 


\subsection{Problem statement}

In the context of the scarcity of natural resources, the government of Rwanda attaches high importance on natural resources conservation by creating protected areas likely to increase the tourism revenue income.

Tourism has been among the top priorities in Rwandan political debates whereby it has become the first sector contributing to the GDP (RDB, 2017). For example, 12.7\% of the Rwandan GDP is generated from tourism (RDB, 2017). However, communities living adjacent to protected areas with the richest biodiversity are the poorest (Imanishimwe et al., 2018; Masozera, 2002; Plumptre et al., 2004; REMA, 2011).

The Nyungwe National Park (NNP) ranks among the most important regions of the world for the conservation of birds and thirteen types of primates which represent $1 / 5$ of Africa's primate species (Rutebuka, 2012). The NNP is one of Rwandan water towers, sheltering $60 \%$ of the national waters and as the source of Nile. NNP also hosts 39 plant species which are threatened with extinction and some of them are rare (ORTPN, 2004; Plumptre, 2012). Human dependence on the NNP is a multifaceted phenomenon since it provides a diverse stream of benefits to Humans.

Since 1998, Rwanda has adopted a decentralization policy to ensure democratic governance, accountability, and community participation in the decision-making process (Chemouni, 2014). In the same orientation, Rwanda adopted a new approach of reconciling environment and community needs through eco-tourism. The tourism revenue sharing has been adopted as a tool of empowering local communities surrounding protected areas including but not limited to national parks. In this regard, the rate of contribution from income generated in tourism activities has increased from five percent in 2005 to $10 \%$ in 2017 of the total gross revenue earned in each national park (GoR, 2018). RDB usually donates a portion of revenue from wildlife-based tourism to assist local communitiesbased projects living adjacent to national parks in socio-economic development. However, the current incentives package or budget allocated to the communities, mostly very poor people, surrounding national parks is seen as insufficient to cater to their needs (Imanishimwe et al., 2018; Plumptre, 2012). 
As indicated earlier, Rwanda has invested to improve the well-being of local communities living adjacent to protected areas through tourism revenue sharing and local community participation. During Gorillas naming ceremony happened in Rwanda in 2019, Belise Kariza, the chief tourism officer at Rwanda Development Board said, "Since 2005 when tourism revenue sharing was initiated, more than $\$ 5.8$ million was invested in 647 development projects around Virunga, Akagera and Nyungwe national parks". In fact, "Through tourism revenue sharing different project were financed and community cooperatives were supported where about 1,133,195,986 Rwf were invested in 152 different developmental projects of local communities in the districts adjacent to Nyungwe National Park from the year 2005 to 2017" (Imanishimwe et al., 2018, p. 4-5). Among these projects some are created for sustainable income like building schools in Nyamasheke district, health clinics in Rusizi district, water supply in Nyaruguru and local communities' projects like fodder project in Nyamagabe and Maracuja project in Nyamasheke. Not only that but also some cooperatives were supported like beekeeper's cooperative in Nyaruguru district (Imanishimwe et al., 2018).

However, the reality on the ground is quite far from the expected. According to EICV 5(2018) the local communities are still poor. Extreme poverty in communities surrounding Nyungwe park is the most cause of illegal activities and constitutes a big challenge of sustainable conservation of the park. Therefore, the implementation of the aforesaid strategies might be an issue of debate in scientific discourse especially in relation to make visible the voice of local communities. There might be underlying subjective theories that may hinder the successful implementation of the revenue sharing policy and local communities' participation in the management of the park. Basing on the fact that local communities' beliefs are likely to influence conservation practices, it is deemed necessary to conduct an empirical study on the topic to unveil local community' beliefs and perceptions about participation as basis for further conservation goals and activities.

The necessity of conducting an empirical research about local community participation in the context of Rwanda is framed in three dimensions. First, community participation is a worldwide concern aiming to achieve successful conservation programs. Second, in its vision 2050, the Government of Rwanda envisages to boost social and economic development by equipping its community with skills and knowledge as well as power to participate in and to influence decisions. Third, so far, many studies conducted around protected areas focused on the evaluation of the impacts of policies on socio-economic conditions of the surrounding communities. 
On the one hand, scholars have conducted scientific studies on the impact of revenue sharing on social and economic development of local communities (Imanishimwe et al., 2018; Kamuzinzi et al., 2015; Tusabe \& Habyalimana, 2010; Umuziranenge \& Muhirwa, 2017).

It is indicated that tourism revenues contribute to socio-economic development through construction of infrastructures like schools, health facilities, water supplies, and the population benefits from trainings related to environment protection, from receiving funds for food security as well as from other income generating activities (Kamuzinzi et al., 2015; Tusabe \& Habyalimana, 2010).

On the other hand, empirical studies indicate that community based projects are failing to achieve their goals due to insufficient management of revenues, top-down governance system, unfair political capital gains, lack of business skills, and conflicts between stakeholders ' interests (Archabald \& Naughton-Treves, 2001; Briedenhann \& Wickens, 2004; Dixey, 2008; Munanura et al. 2016, 2018; Reddy, 2002; Tosun 2002; Umuziranenge, 2019). In addition the relationship between parks and people have been reflected by focusing on examining the socio-economic status of people living around Rwandan national parks (Bush et al., 2010; Plumptre et al., 2004), the evaluation of community-based conservation around NNP (Rutebuka et al., 2012), examining perceptions of tourism revenue sharing impacts on Volcanoes National Park (Munanura et al., 2016), measuring effectiveness, efficiency and equity in payments for ecosystem services (Martin et al., 2014), and evaluating forest dependence and its implications for protected areas management (Masozera \& Alavalapati, 2004).

While the government of Rwanda considers tourism revenue sharing as a tool for local community empowerment and participation, little is known about the experience and local community perceptions towards their roles and involvement in the conservation of the park, the participation of the population in decision making processes and the benefit of the population and challenges they face (Imanishimwe et al., 2018; Kamuzinzi, Shukla \& Ndabaga, 2015; Tusabe \& Habyarimana, 2010). In addition, due to the global trend towards more decentralized and participatory modes of governance (Dearden et al., 2005), it is of relevance to assess the consequences of this shift for local people. Thus, this study assesses:

- Community perceptions about their role and participation in the conservation of the park (Paper 1, 2, and 3),

- How the local community benefits from conservation activities (Paper 1, 2, and 3), 
- How the local community participates and gets involved in decision making processes with regards to the conservation of the park (Paper 1, 2, and 3),

- The challenges that the local communities face as neighbors of the park (Paper 1, 2, 3, and 4),

- Strategies to overcome the challenges that the local community faces (all Papers).

\subsection{Motivation}

The interest to conduct this research rose when I was assigned to teach the course of community conservation at Protestant University of Rwanda. From that moment I became interested to know how the communities living adjacent to protected areas are involved in conservation activities and how they benefit from these activities.

More importantly, there have been and are still criticisms (in media, education forums, and political speeches) leveled against people living adjacent to national parks in particular, that they are not involved in the conservation of the park, that they are the poorest and they should benefit from being neighbors of the park (Adams\& Hutton, 2007). For the benefit of the society, it is of importance to reflect these discussions by research shedding light on the community' living experiences and habits (opportunities and benefits as well as the challenges) as well as experiences with participation practices and approaches.

Therefore, this study aims to contribute to the creation and rise of awareness about the importance of local community participation in natural resources management basing on the experience and living habits of the local people. The study aims as well to contribute to the effort made by the Government of Rwanda in terms of environment protection especially in the tourism sector. In addition, the idea of community participation in the management of natural resources is gaining attention in research I want to contribute to. 


\subsection{Description of the case study of Nyungwe National Park}

The NNP is one of the four national parks in Rwanda. It became a National Park in 2004 with a total area of 1019 square kilometers (GoR, 2017). The Akagera National Park located in eastern province was created in 1934 with an area of 1080 square kilometers. Virunga National Park located in Northern Province was created in 1925. It has a total area is 160 square kilometers. Gishwati \& Mukura Forest Reserve became a national park in 2015. It has a total area of 3,558 Ha and it is in western province. A map of Rwanda locating four national parks is provided in Figure 1.

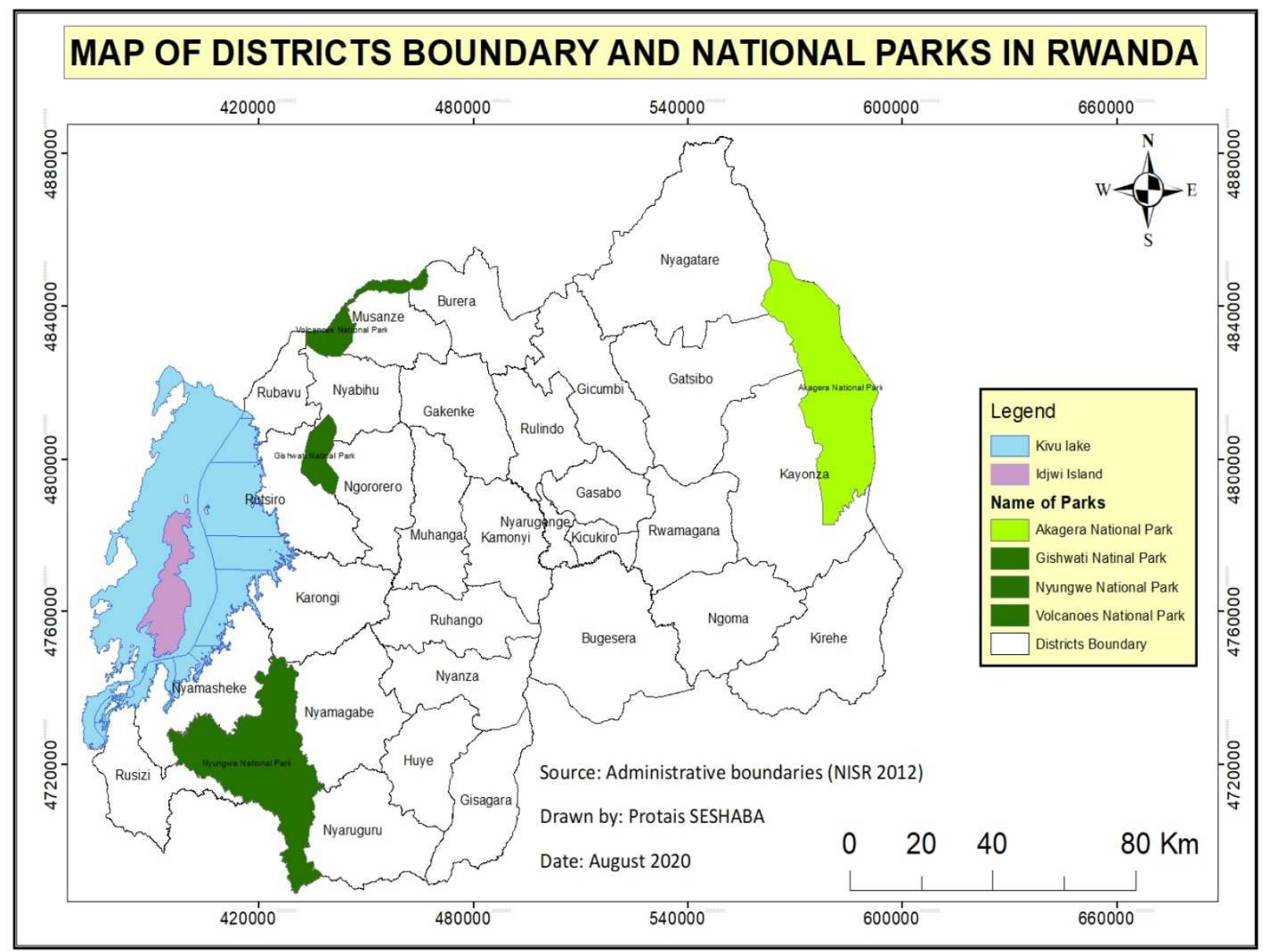

Figure 1: Map of Rwanda with 4 National Parks

Source: (NISR, 2012) 
The Nyungwe forest, South West of Rwanda, was designated as a national Park in 2005 under the law $n^{\circ}$ 22/2005 on November 21, 2005 and has been under protection since 1993, when it was first gazetted as a reserve (Gross-Camp, Martin, McGuire \& Kebede, 2015). A map of NNP is provided in figure 2 showing administrative districts and sectors intersecting the park (Karongi, Nyamagabe, Nyamasheke, Rusizi, Nyaruguru). Kitabi sector in Nyamagabe district, Rangiro, sector in Nyamasheke district, Bweyeye sector in Rusizi district and Kivu sector in Nyaruguru district were selected for data collection because many conservation activities are based there.

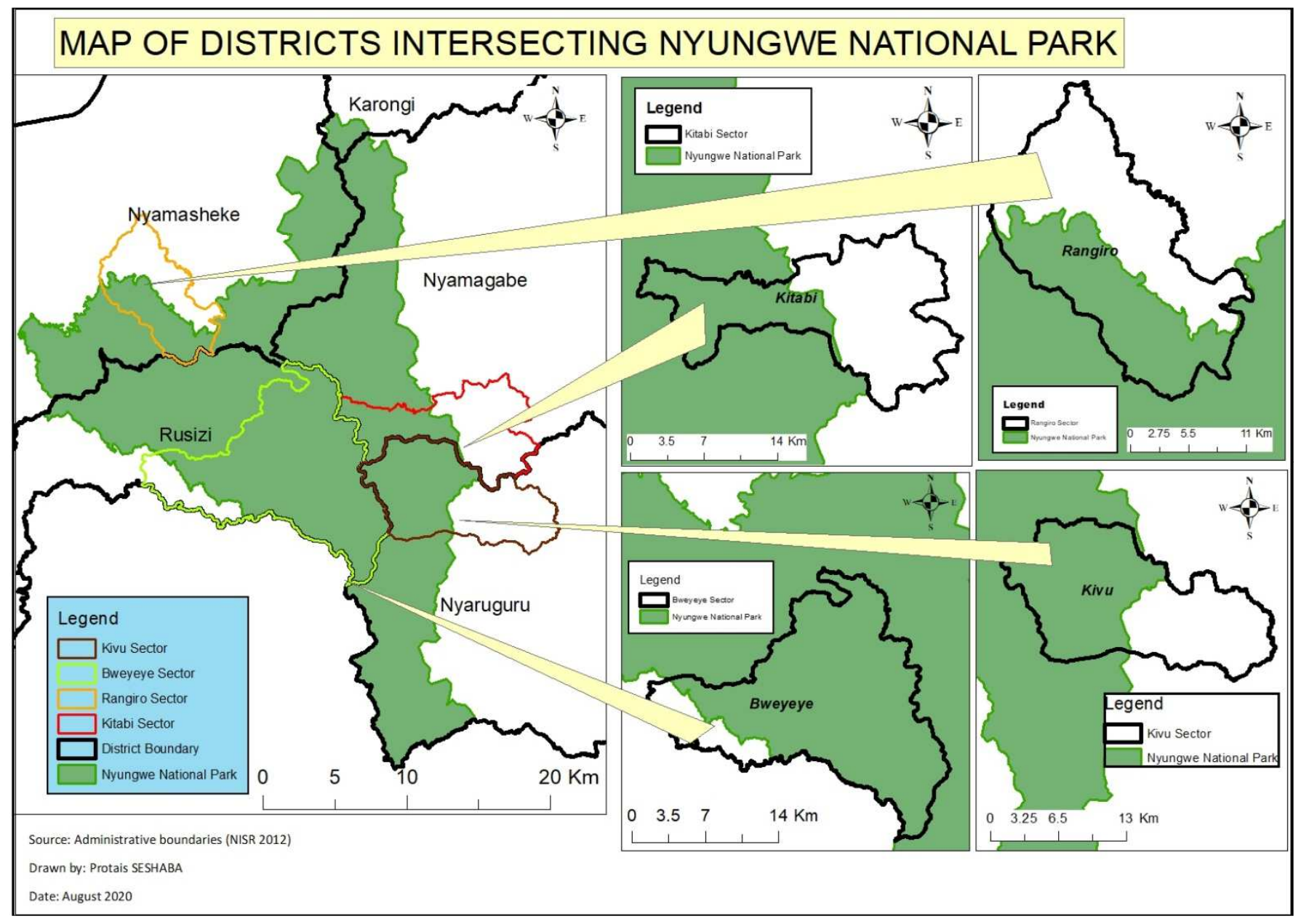

Figure 2: Map of NNP and its intersecting districts and sectors

Source: (NISR, 2012) 
NNP is the largest mountainous forest remaining in Africa and home to 20 percent of all African primates, including 13 primate species, as well as 280 bird species (including 25 endemic species), 43 species of reptiles, and 85 mammal species. There is also an extremely rich plant life with more than 240 species of orchids (Plumptre, 2012). Due to this potential, NNP was recognized as Rwanda's leading ecotourism and adventure destination that complements other tourism destinations while providing optimal economic benefits to neighboring communities (Kambogo, \& Bizimana, 2016; RDB, 2011).

The zones surrounding Nyungwe are populated with a more or less 300 inhabitants per square $\mathrm{km}$. More than $90 \%$ of these communities are subsistence farmers, with family cultivating of an average less than 1 ha per household, characterized by a lack of sustainable sources of income (Crawford, 2012; EICV5, pp. 27; GoR, 2009, 2014; Kambogo \& Bizimana, 2016; Masozera \& Alavalapati, 2004; NISR, 2018; Richmond et al., 2015). Apart from its importance for maintaining biodiversity, the NNP plays a big role in the surviving of the neighboring community. It provides biological services, by means of water catchments, and balances out soil disintegration and erosion for the surrounding community. From the time when Nyungwe was a Natural Reserve, the population entered the forest no matter how in different activities like mining, woodcutting, timber, herbs collection for medicine, honey collection, poaching of animals and searching lands for cultivating. These activities were not considered as illegal activities rather considered as source of economic and social living. The local community considered the forest as their own heritage where they could explore everything.

Since 2005 when Nyungwe forest was declared a national park and officially a protected area, policies, regulations, and institutional frameworks were carried out in order to help the Park's management. Since that time, the use of resources from NNP by the local community is restricted. This situation created tensions between the local community and decision makers (conservationists). 
Therefore conservation initiatives around NNP are still challenged by: (1) the increased population pressure, (2) a high rate of poverty of the surrounding populations, (3) a high reliance on natural resources, especially on agriculture for livelihoods, (4) important forest and bush fires, (5) hunting pressures on largest mammals, (6) artisanal and industrial mining and (7) deforestation for firewood, medicine, grass for cattle and construction materials (Crawford,2012; Grace, 2019; GoR, 2014; Imanishimwe et al., 2018; Masozera, 2002; Mulindahabi \& Kubwimana, 2010; Plumptre, 2012; REMA, 2015; RDB, 2012).

\subsection{Research objectives}

The present study aims to examine the community participation in natural resources management. It intends to investigate whether during the implementation of the tourism revenue sharing policy, the involvement of local community is genuinely and professionally done both to meet the expectations of the local community and conservation outcomes.

As specific goals, the study aims:

- To assess how local community, understand and participate in conservation of natural resources management with the case of Nyungwe National Park.

- To assess benefits and opportunities that local community gets as neighbors of the park through ecotourism.

- To understand how local community, participate in decision making process.

- To identify challenges that faces the local community and hinder them to participate fully and efficiently in the management of the park.

- To suggest ways to minimize the challenges that the local community faces as neighbor of the park.

Given its ecological importance as a mountainous rainforest and the great surrounding pressures and degradation, the Nyungwe National Park (NNP) was chosen to be the study area. 
The framework of this study is illustrated by Figure 3 below:

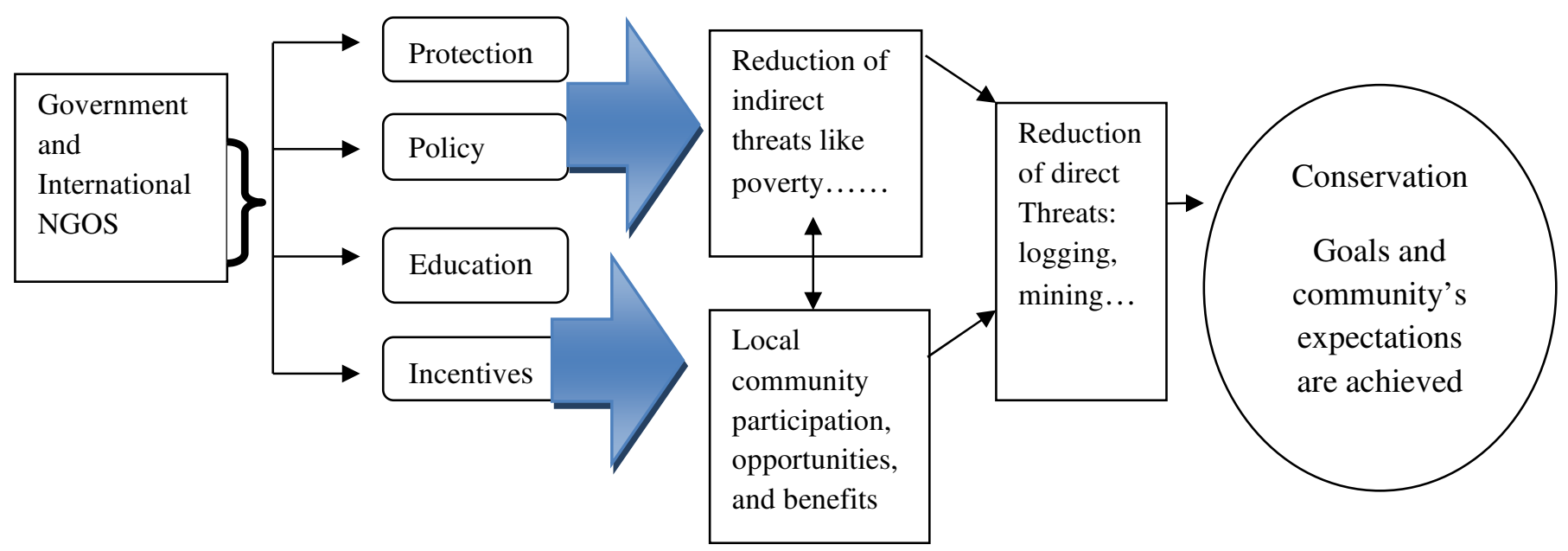

Figure 3: Research framework of this study

\subsection{Research focus}

This study intends to explore local community' thinking concerning community participation in the conservation of natural resources in Rwanda with the case of Nyungwe National Park. The focus of this research is on the local community as local community attitudes and perceptions influence conservation goals. People's livelihoods rely on the extraction of natural resources, local people resent imposed conservation ideas and tend to hold negative attitudes toward wildlife conservation and park management authorities (Nepal \& Weber, 1995; Spiteri \& Nepalz, 2006). Positive perception of benefits and opportunities from the parks expects people's attitude towards conservation (Moswete et al., 2020; Ormsby \& Kaplin, 2005). However, wildlife-human conflicts and lack of access to the park's natural resources are negative impacts on local communities neighboring the park (Karanth et al., 2013; Mc Guinness \& Taylor, 2014; Michalski et al., 2006; Naughton-Treves, 1998). Thus, the major research question under this study is, what perceptions do local community hold about community participation in natural resources management? The research seeks to answer the following specific research questions:

- How do local communities participate and perceive their role in the conservation of the park?

- What are the benefits and opportunities do they get as neighbors of the Park?

- How do they participate in decision-making process? 
- What are challenges do they face being neighbors of the park?

- What do local communities wish to minimize the challenges they face?

The answers to the previously mentioned questions will shed light about types of participation and the role of the local community in conservation of the Nyungwe National Park.

\subsection{Significance of the Study}

The success and effectiveness of protected areas management depends on involvement of local communities, and consideration of their needs as the primary users of natural resources (Allendorf et al., 2006; Andrade \& Rhodes, 2012). In the effort to gain community support and involvement in the conservation of natural resources, conservation decision makers in Rwanda integrate a component of local community well-being and needs into their conservation priorities. An understanding of the role of the local community and their expectations as well as their attitudes towards conservation can assist in the success of both conservation and community well-being goals. Thus, the focus of this study is on local community participation in park management.

Based on the predicted relationship between the impacts of the administration of parks and adjacent communities, their attitudes and behaviors (Ormsby \& Kaplin, 2005), the assessment of the understanding of the related groups can contribute to evaluate conservation efforts, and therefore support the protection of natural resources as well as the livelihood of local residents.

Furthermore, an understanding of the perceptions from the local community on the benefits they get as park neighbors, is very necessary in engaging themselves in protected areas management and wildlife conservation as well as be supportive to conservation initiatives (Anthony, 2007; Moswete et al., 2020; Ormsby \& Kaplin, 2005). It can reveal opportunities for improving relationships, and community conservation programs as well as informing policy makers and park managers. In this way, it can assist in achieving conservation goals as well as expectations of local community to maximize benefits as neighbors of protected areas. 


\subsection{Structure of the synopsis}

This synopsis considers five papers. In the next chapter (chapter 2) the literature review on governance, democracy and community participation, social justice and community empowerment, ecotourism and empowerment of local community around protected areas, human-wildlife conflicts and conservation practices and challenges in Rwanda are introduced to position the research and provide important information for interpreting the empirical data. The research approach and methods are elaborated including an overview of the study design and analysis in (chapter 3). The following chapter (chapter 4) contains a summary of the findings of the empirical research, published in the five papers on which this synopsis is based. A discussion of the findings and conclusion is elaborated in chapter 5. Implications of the study are elaborated in chapter 6. 


\section{Literature Review and Conceptual Framework}

This chapter presents the literature relevant to the findings of the study; the reviewed literature is about governance, democracy and community participation in developing societies (2.1), about social justice and community empowerment (2.2), eco-tourism and empowerment of local communities around protected areas (2.3), human-wildlife conflicts around protected areas (2.4) and the nature of conservation practices and challenges in Rwanda (2.5). The literature review refers on general discussions but tries to focus on research in SSA and Rwanda in particular. The literature review provides information depicted from community participation and involvement in natural resources management from various perspectives related to the study. The literature review shows the importance of social and cultural contexts in the human experience especially in resources management and highlights the relevance of the integration of social and economic components in conservation goals as well as the needs of enhancing local community participation and empowerment for better conservation outcomes.

\subsection{Governance, Democracy and Community Participation}

I have chosen to discuss about governance, democracy and community participation since these aspects are inter-linked with the process of conservation of protected areas.

According to Borrini-Feyerabend et al. (2013, p. 10), "Governance is a set of interactions among structures, processes and traditions that determine how power and responsibilities are exercised, how decisions are taken and how citizens and other stakeholders have their say".

Governance approach through decentralization and participation modes have been awarded more attention in natural resources management by ensuring the integration of processes, procedures, resources, institutions and factors that determine how decisions are made and implemented (Dearden et al., 2005; IUCN, 2004; Macura et al., 2015). 
Democracy is a form of governance that considers societal concerns and priorities. Its role is to allow equal right of participation in the political process (Michels, 2006; Redoano, 2004). In democracies, the governance system in decision making processes considers local communities as an important element by involving them in decisions in order to increase the complexity of decision making, to enhance appropriate measures, and to decrease tensions between the population and governmental bodies. By this, the conservation of natural resources, the fitting approach and the practice to nearby conditions, by empowering local community and promoting local community ownership, is considered as improving (Ban et al., 2014; Cetas \& Yasué, 2017; Reed, 2008; Ribot, 2002). Due to the global trend towards more decentralized and community participatory modes of governance, it is of necessary to assess the outcomes of this shift for local people, especially those living adjacent to parks. It is the question how the population is affected by this new approach of governance. With the papers of this study, governance issues are addressed as pertaining to different governance approaches such as top-down, bottom and partnership approaches. These are key factors that affect people's perceptions about participation and appreciation of the conservation initiatives (Bennett, 2016).

In paper 1, I assess how people perceive the governance approaches used in the conservation of NNP and how they participate in the conservation of the NNP, how they are empowered to be able to participate, and kinds of the challenges they face as neighbors of the Park. The above subquestions reflect mitigating threats to biodiversity and to the acceptance of conservation decisions by the local community. This paper draws on theory of effective community participation (adapted from Michels, 2006; Paudel, 2009; Pretty, 1995; Reed, 2008; Reddy, 2002).

Communities are heterogeneous entities, where people and institutions have diverging interests (Ojha et al. 2016). According to Alexander et al., (2016), it is therefore of relevance to identify the values and interests among actors in community-based conservation both to gain knowledge on how to devise conservation initiatives that resonate with people and also to assess the interests of influential actors to determine which policy options likely will be favored by the local community (Bennett, 2016; Newig \& Fritsch, 2009). This is the reason why paper 2 assesses in particular how women as an important group in the conservation of natural resources are empowered to be able to take part in the conservation of the park. The paper assesses what benefits do women get, how they are empowered to take decision, and the challenges, especially women face. 
Both papers seek to provide knowledge to fill gaps about the living experience of the local communities on how community participation policy affects their lives.

During the last decade, participation of surrounding communities has been a concern in the discourse of natural resources management. Scholars show different approaches of community participation that are likewise relevant for natural resources management. Among others, there are top-down, bottom-up and partnership approaches. The top down approach describes the situation where the government provides and decides for the community. This approach seems to be quick and less expensive; however, it does not consider contextual realities and needs of local communities likely to engender conflict between different stakeholders (Pretty, 1995; Reed, 2008). It is known as traditional approach in decision making and it is no longer satisfying citizens.

After having realized that the top-down approach is failing to meet community expectations and conservation goals, a concept of democratic decentralization emerged. It is any act in which a central government gives power to actors at lower levels in a political-administrative with evidence that those most affected by a decision should have a bigger role (Berkes, 2010; Reed, 2008; Ribot, 2002). The primary logic of decentralization is that democratic local institutions can better determine and are more likely to respond to local needs and aspirations because they have better access to information and knowledge due to their closeness and are more easily held accountable to local populations (Ribot, 2002).

The democratic decentralization approach includes cases where the government grants decision making power to local governing bodies (i.e., democratic decentralization), the local communities own or have usage rights in the conserved area (Agrawal \& Ribot, 1999; Hausner et al., 2012; Poteete \& Ostrom, 2004). It is characterized by a bottom-up process where decision making starts at the local level and involves interactions at multiple levels (Baral, 2012; Berkes, 2006). The needs of the local communities are the starting steps for policymaking in bottom-up approach. However, this approach is criticized because communities are not well equipped to critically analyze contextual realities as well as appropriate solutions. 
According to Redoano (2004), democratic decentralization has two types: representative democracy and direct democracy. On one hand representative democracy is decision making by elected and appointed officials. Within such an approach, the public mainly expresses values and interests by means of its voting power. In representative democracy the decision is made, and public is informed (induced participation). On the other hand, direct democracy is a decision-making characterized by active participation of citizens in decision making. The decision is made and shared together with the public. In direct democracy, participation is an education experience as well as a process for positive self-transformation. It is on learning experience within the participants acquire the skills for effective decision-making. In this case participation become a vital educational process where people are educated, informed, and involved to have a sense of control over their own lives and concerns for the entire community. In Table 1, the concept of governance, democracy and community participation is visualized.

\begin{tabular}{|c|c|}
\hline Participation plays a minor role & Participation is an essential feature \\
\hline$-\quad$ Representative democracy & - Participation democracy \\
$-\quad$ The focus is on political leaders & $-\quad$ Participation is active \\
$-\quad$ Participation is instrumental & $-\quad$ The focus is on citizens (empowerment) \\
$-\quad$ Participation has no educative or social & $-\quad$ Participation has both educative and social \\
functions & functions (learning and sharing of \\
$-\quad$ No relation between participation and good & information) \\
- governance & Participation is a way of ensuring good \\
$-\quad$ Top-down approach, coercive participation & $-\quad$ governance (participation in decision making) \\
$-\quad$ Induced participation & participation is desirable \\
& $-\quad$ Participation may be spontaneous \\
\hline
\end{tabular}

Table 2: Views on governance, democracy, and community participation

Source: Own design (inspired by Michels, 2006; Paudel, 2009; Pretty, 1995; Redoano, 2004; Reed, 2008; Reddy, 2002; Tosun, 1999, 2000; Umuziranenge paper 1, 2, 2019). 
A partnership approach of community participation involve local communities and policymakers to closely collaborate in order to meet their respective needs (Paudel, 2009, Reddy 2002). The book Empowering Communities through Participatory Methods by G. Narayana Reddy describes a partnership and bottom-up approach, where the government and the community work together in planning and decision making (Reddy, 2002).

By this, the community should be empowered to have greater knowledge, control, authority, and thereby promote equitable sharing of costs and benefits. However in some cases, higher level authorities are needed in order to re-distribute the costs of conservation, build institutions, provide funding, give recognition and support of conservation efforts, link rural and urban areas, and generate new income opportunities for rural communities, for coordination, and technical and scientific expertise (Eckerberg et al., 2015, 2020; Wijayaratna, 2004). The shift from traditional top-down model to community conservation approach is likely to be more successful. However, the success depends on how it considers the new power relations and inclusivity as Kapoor (2001) noted.

In natural resource governance, local community and decision makers interact and make decision decisions regarding the resource use. According to Borrini-Feyerabend et al. (2013), governance of protected areas is about who decides what to do, how those decisions are taken, who holds power, authority, and responsibility and who is accountable. By considering different stakeholders around protected areas with different interests, natural resource governance seems to be a difficult challenge as decisions that are undertaken have to fit all stakeholders and need to be understood by everyone in the process.

For long time, the community was considered as having more interests in resources and therefore exploit them for their own profit without any consideration. With this view decision making bodies advocate for restriction and remover of the community from resources use as a good approach for protecting natural resources (Adams \& Hutton, 2007; Adams et al., 2004; Brockington, 2002; Doolittle, 2007; Peluso, 1992, 1993; Siurua, 2006). 
Contrary since the early 1980s, economics, sociologists and cultural anthropologists have documented cases of sustainable natural resources management by local communities and proved that there were some communities who managed to conserve the resources from which they depend upon where local institutions and communities created their own rules, monitored its compliances in the community around and sanction those who broke rules (Baerlein et al., 2015; Berkes, 1986; Borrini, 2013; Ostrom, 1990). An example of such community's involvement are Van Panchayats of Uttarakhand in India, Kawawana, a community conserved area in Casamance (Senegal), and Kyrgyzstan in Central Asia, which have shown ownership in natural resources conservation and reflection of the importance of resources with regards to the well-being of the community. Those communities respond better in a self-governance setting in terms of rules compliance, distribution efficiency and equity. This also shows the relevance of a bottom-up approach in managing natural resources and formation of conservation policies which involve all stakeholders from the grassroots local government level to the agency level, where these stakeholders with diverse needs and values come together and develop a plan that fit and meets the needs of everyone.

In some countries decision-making in natural resources conservation become a serious issue due to the opposition between biocentric and anthropocentric views. People with biocentric views consider local community as enemies of protected areas and natural resources and restrict them from the management of natural resources, while people with anthropocentric viewpoint understand local community as important in management of natural resources and therefore respect people's right.

Reducing human pressures on ecosystems is necessary for favorable ecological outcomes of protected areas, but conservation initiatives that rely on strict enforcement without local involvement are vulnerable to a reduced political commitment, rule-violations and public protests (Lindenmayer et al., 2017; Stern, 2008). However, according to Irland (2008), natural resource governance policies are threatened with challenges like corruption, nepotism, inadequate and ambiguous policies, lack of improper policy implementation and unequal resource distribution and utilization. Some claim that community-based conservation initiatives have struggled because expectations have been too high and protected areas have failed to generate enough benefits for local communities to create incentives for conservation (McShane \& Newby, 2004). Another reason is that successful projects in terms of conservation outcomes failed to provide economic 
benefits, and attribute success to non-cash benefits like enhanced community confidence (Salafsky et al., 2001).

Engaging stakeholders can be expensive and time consuming, increasing the range of perspectives can increase conflict, participants may develop diverging views after considering the viewpoints of others, they may lack the knowledge and capacity to make quality decisions, a lack of commitment from the initiating agency can reduce support, and if dominant actors are awarded too much leverage this can reduce equity (Stern \& Dietz, 2008; Ward et al., 2018).

Paper 1, 2, 3 and 5 indicate that the Government of Rwanda initiated the policy of decentralization and community participation in the conservation and preservation of the parks. The new approach has brought new perspectives and hope for sustainable conservation. Many NGOS have moved to work along the population to empower them and accompany initiatives, entrepreneurship and projects that overturn their depending eternally on the natural resources of the parks.

Regarding the governance system of the park, the top down management model (governancecentered approach) is still dominant in the processes including the definition of the policies, the monitoring and evaluation of the revenue of tourism. The level of community involvement in decision making is not yet clear on the ground and local communities are informed about decisions that have already taken. In the processes of NNP governance and management, the following challenges are still to be addressed: (1) the persistence of centralized and coercive management methods, (2) the persistence of human-wildlife conflicts and the lack of effective and equitable economic compensation systems, (3) the limited socio-economic benefits of ecotourism and of activities of exploitation of resources.

To be more effective, natural resources governance and community participation processes must empower stakeholders through education, raising awareness through community mobilization and creating jobs so that they can increase knowledge and capabilities to influence political decisions. There should be a flow of information exchange from decision makers to stakeholders about projects that are to be developed. 
Local communities should be given the ground to identify their needs so that they are helped to formulate projects and be actively involved through a partnership approach"3.

\subsection{Social justice and community empowerment}

According to Schlosberg (2007) justice is identified with a person's abilities or substantive opportunities in being capable to acknowledge different functioning. The ability approach in this manner offers an understanding of distributive equity, capabilities, recognition, participation, and procedural justice. Therefore, social justice includes the designation of rights, goods and freedom in a general public, social and financial fairness, recognizing the role of everyone, promotion of capabilities for better functioning as well as inclusion in decision making process. One can ask if the communities around protected areas are benefiting from their resources and are treated equally. How do they participate and how are they involved in the decision-making process as an element of social and environmental justice? These questions are raised in paper 2 and answered in relation to the case of NNP in Rwanda.

In Nancy Fraser's (2008) three-dimensional account of justice, redistribution, recognition, and representation, are highlighted. According to Fraser's understanding, injustices in natural resources management and conflicts may arise when decision makers ignore voice of community members and reject their ability to participate. Therefore, conservation and development strategies require guaranteeing equity as equality of interest and consider social plans that allow all persons to take part as companions in social life. Thus, the increase of community participation and their involvement improves equity and empowerment of the community (Reed, 2008) while inequity in engagement processes lead to disputes and conflicts among different actors (Leciejewski \& Perkens, 2015). The implementation of different policies and initiatives relating to the conservation of protected areas should consider the voice and consultation of the local community otherwise social injustices at intersecting scales can occur and lead to the social exclusion of the global poor (Fraser, 2010).

\footnotetext{
${ }^{3}$ These Paragraphs refer to aspects being published in paper 1, 2 and 5 on governance approaches and community participation
} 
Environmental justice and community empowerment are closely interlinked. In this regard, it is worthy to describe how scholars conceptualize the previously mentioned terms before showing how they are related. Environmental justice is a concept which can be defined in different perspectives by different scholars. It can be seen as a process of dealing with all justice related issues in environmental management through distributive and procedural dimensions (Fraser, 2008; Ikeme, 2003).

On the one hand, the distributive dimension is concerned with equity as regard to dealing with people's outcomes in social exchanges (Brashear et al., 2002; Fraser, 2008). It concerns mainly by distribution of costs and benefits among communities living in the protected areas. Procedural justice is related to the procedures and processes (Fraser, 2008; Sheppard et al., 1992) on the other hand. This is concerned by the extent to which communities are involved in the process of decisionmaking (Svarstad et al., 2011). Regarding community participation, Pretty (1995) gives a model of participation indicating different forms of participation. They include manipulative (through unelected representatives), passive (receptive of information), consultation, material incentives, functional (by serving to achieve external project goals) and interactive participation. Though no form can fit all contexts, interactive participation might be important in regard of considering the needs of concerned people and organizations or systems (Reddy, 2002).

In the context of conservation, procedural environmental justice regards how people living in protected areas are empowered to make decisions regarding conservation policies as well as their own development projects. As indicated earlier, environmental justice is closely related to community empowerment. The relationship is described based on two dimensions of environmental justice. First, equity in cost and benefits from natural resource management is a mean of social and economic empowerment of the local community (Walpole \&Thoules, 2005). For example, tourism revenue sharing is a tool for not only engaging surrounding communities but also contribute to their socio-economic development (Imanishimwe et al., 2018; Kamuzinzi et al., 2015; Umuziranenge \& Muhirwa, 2017). 
Community participation is considered as a tool for empowerment, building beneficiary capacity, increasing effectiveness in the desire to share costs, and improving the efficiency and success of the projects. People should have the relevant assets and instrumental freedoms (representation and consultation) to achieve different needs, including human assets (health and education); natural assets (having access to resources); and physical assets by access to the infrastructure. Communities are not only empowered by providing incentives but also through involvement in decision-making process (Svarstad et al., 2011). With procedural environmental justice, people are empowerment to become agents of change. They are expected to be independent and make decision on their own by building trust in such a way that they can empower themselves (O'Neil \& Domingo, 2015, Willis, 1999). It is important to note that participation in decision-making is a crucial element to ensure sustainable development processes and create an influence on norms and value (Mensah \& Casadevall, 2019). The involvement of the locals including women, youth and other groups is a driver to the success of development initiatives to avoid social injustices at intersecting scales that can occur and lead to the social exclusion of the global poor (Fraser, 2010). Thus, environmental justice (distributive and procedural) is a mean through which population surrounding protected areas may be economically and socially empowered.

\begin{tabular}{|l|l|l|}
\hline $\begin{array}{l}\text { Eistributive Justice- } \\
\text { sharing cost and benefits }\end{array}$ & $\begin{array}{l}\text { Community } \\
\text { Empowerment } \\
\begin{array}{l}\text { Procedural Justice- } \\
\text { participation in decision- } \\
\text { making }\end{array}\end{array}$ & $\begin{array}{l}\text { Economic and social } \\
\text { empowerment }\end{array}$ \\
\hline
\end{tabular}

Figure 4: Relationship between environment justice, community empowerment, and natural resources conservation.

Source: Umuziranenge paper 2, 2019, p. 81 (inspired by Fraser, 2008; Pretty, 1995; Svarstad et al., 2010) 
Distributive justice leads to the empowerment of the local communities and the achievement of the conservation goals. In paper 2, sharing costs and benefits from the conservation of the park with local communities especially women improve their socio-economic conditions. This sort of empowerment leads to the satisfaction of women with regards to employment, health insurance, food security and environmental raising awareness. This corroborate the point of view whereby increasing women participation and empowering them, lead to better conservation outcomes as they have privileged knowledge and experience of working closely with the environment. Procedural justice leads to the empowerment of the local communities in decision making.

Paper 2 indicate that the level of women participation in decision making process is still low. To be effective, environmental justice must consider empowering local communities in a way that they should be able to influence political decisions, especially women. Their voices must be heard and be considered. Hence, the procedural justice as an element of social justice aspect needs to be reinforced in the process of conservation of $\mathrm{NNP}^{4 "}$.

\subsection{Ecotourism and empowerment of local community around protected areas}

Paper 1, 2, 3, and 5 explain the role of ecotourism in empowering the local communities who live adjacent to protected areas. Opportunities and Challenges are also discussed.

Authors indicate that various political and economic instruments that aim to combine environmental objectives with socio-economic development goals, have been implemented by states all over the world based on the idea that if conservation and development can be linked then, the interests of both can be served (Berkes, 2004; Saarinen, 2006). The major objective of ecotourism is to empower and provide benefits to local communities. Therefore, sharing revenues from tourism with the local communities promote community conservation outreach through projects that in line with ecotourism principles, thereby promote and enhance conservation relations and minimize negative impacts from both wildlife and local communities around national parks.

\footnotetext{
${ }^{4}$ These Paragraphs refer to aspects being published in paper 2 and 5 on environmental justice
} 
Ecotourism has been proposed as a viable economic activity that can minimize negative human impacts on wildlife habitats yet provide an incentive to preserve natural area. This approach also attempts to decrease local people's dependence on natural resources by substituting alternative livelihood activities where those mentioned natural resources are intrinsic to everyday livelihood as local people's willingness to participate in biodiversity conservation and landscape protection depends, to some extent, on whether their basic needs are satisfied since they rely on natural resources for their survival (Chirozva , 2015; Cobbinah, 2015; Fennell, 2015; Lin \& C-F L, 2013). It is a process of providing alternative ways of making a living (e.g., the provisioning of alternative fuel to prevent forest-degradation or economic compensation to outweigh the costs of changing to a less environmentally harmful behavior (Nilsson et al., 2016; Zacarias \& Loyola, 2017).

Ecotourism has been defined as an umbrella term to mean responsible travel to natural areas that conserves the environment and improves the well-being of local people by focusing on increased economic benefits, non-economic impacts, respect of different cultures, human right and policy processes (Zacarias \& Loyola, 2017). One of the principles in ecotourism scheme is that it provides financial benefits and empowerment for local people by providing to them incentives (Kipkeu et al., 2014). Among these economic benefits that increase business and employment opportunities, are of importance. The non-economic benefits include building capacity and the empowerment of poor people as well as the mitigation of the environmental and socio-cultural impacts of tourism on the local community. Finally, policy processes include building more supportive and planned frameworks that enhance participation of the local community in the decision-making process where tourism must be financially reasonable, environmentally delicate, and socially suitable (Zacarias \& Loyola, 2017). In addition, it is considered as a sustainable development tool that holds many potential economic benefits for host communities, including increased employment opportunities, improved socio-economic conditions and greater market stability than are provided by traditional commodity exports. It contributes to economic growth of countries as it generates income for the local community; the creation of new employment opportunities; improvements to the structure and balance of economic activities in the neighborhood communities and the encouragement of income generating activities (Ashley \& Garland, 1994). 
A case of how the local community has concentrated endeavors on amplifying profits by tourism activities around national parks can be found in Mpumalanga Province in eastern South Africa /Transvaal. There, towns contiguous to the Kruger National Park have begun to concentrate on offering extra tourism activities which initiated businesses and, in this manner, rise the effect of the park in the district (Saayman \& Saayman, 2006).

In Rwanda, since 2005 a tourism revenue sharing scheme was initiated which aims at sharing 5\% of tourism income between the nation and the community, encompassing the recreation center of neighborhood communities that bears the cost of its preservation and additionally advantage from it. The Rwanda Development Board invests $40 \%$ of total revenue-sharing funds to support local community' projects, with the remaining $60 \%$ funding the local infrastructure. This is to ensure that the local people consider the parks as their own. On the environment side, this is one of the ways that can increase awareness amongst local people with the hope that they will support conservation and contribute to natural resource protection. Defenders of tourism revenue sharing (TRS) philosophy including Archabald, argue that it promotes tourism development and ensures that local communities enjoy tangible benefits from the industry while participating in wildlife conservation (Archabald \& Naughton-Treves, 2001).

Sharing tourism benefits with local communities has always been a controversial issue, whatever approaches of community participation in tourism industry are involved as Tosun (2000) noted. Although there is no doubt that tourism can generate considerable benefits, another dimension of the problem has been raised about the inequitable distribution of costs, benefits and power among different actors on different scales, where there is insignificant economic impacts at local destinations and just couple of local people's advantage or is included in decision making (Blanco \& Razzaque, 2011; FAO, 2005; Rice, 2007).

Tosun (1999) suggests three forms of community participation, which are spontaneous, induced, and coercive community participations. Spontaneous community participation is voluntary with full responsibility and authority owned by the community. In the case of induced community participation, it is either the government who takes the decisions, but the communities are involved in implementation. Coercive participation is top-down approach like induced participation, where the community participates in implementation but not in benefits sharing. 
Estrella and Gaventa have observed that the community is often involved at a stage of implementation not in the whole process like project identification and preparation as well as monitoring and evaluation (Estrella \& Gaventa, 1998). This failure to engage the community at all levels of processes led Reeds et al., (2006) to suggest that engaging the community at early stage of the project cycle not only provide better decisions outcomes but also strengthen trust among the community and the conservationists. For Reed, Dougill and Talyor (2007), the combination of local knowledge and scientific knowledge should be considered while empowering the community to monitor and manage environment projects. Another constraint of ecotourism is that tourism development is associated to habitat degradation, increased water and energy use, increased littering, disruption of local social values, social imbalances, child labor and prostitution among other negative impacts (Zacarias \& Loyola, 2017). Ecotourism has been proposed as a tool of local community participation and empowerment through engaging them as members in the public and tourism related decision-making bodies (Umuziranenge \& Muhirwa, 2017; Zhao \& Ritchie, 2007).

Participation in the decision-making process is a crucial determinant to ensure that the benefits local communities get from tourism are partly guaranteed, and their lifestyles and values are respected. It is a way of enabling a social environment in which one can make decisions and make choices either individually or collectively for social transformation by strengthening the native ability to acquire skills, knowledge, power and experience (Chambers, 1994; Chok \& Macbeth, 2007; Li, 2005). Various studies including the one of (Tosun, 2006) has indicated that local community participation in tourism development can be achieved through involving a committee elected by local communities or through joint decision-making by both appointed and elected local government agencies or by consultation with the local community residents. However, this requires a commitment of the government to empower the local community in terms of building beneficiary capacity, increasing effectiveness in the desire to share costs, and improving the efficiency and success of the projects. The following figure 5 illustrates the links between ecotourism and local communities' empowerment. 


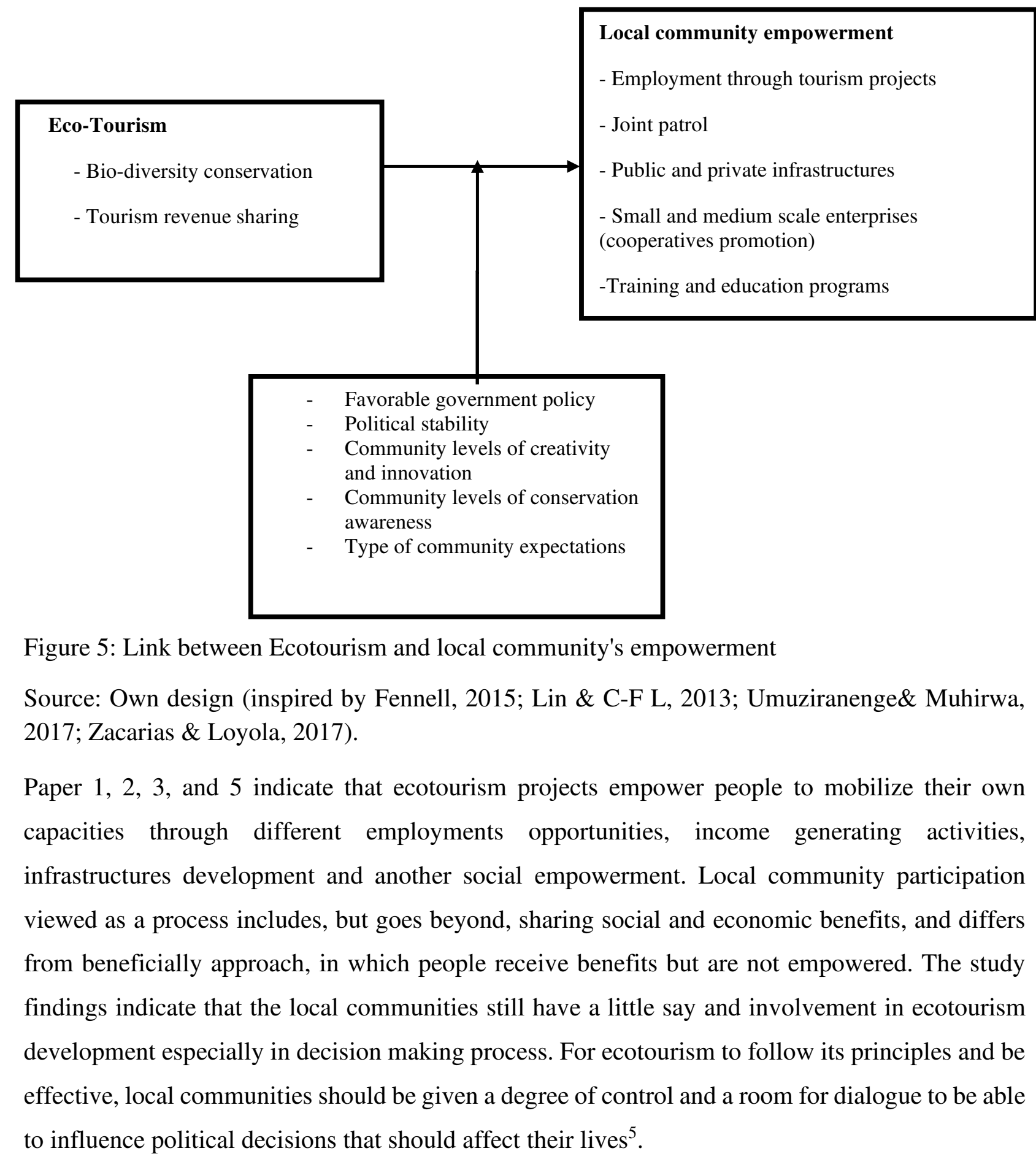

${ }^{5}$ These paragraphs refer to aspects being published in paper 1, 2, 3 and 5 on ecotourism, natural resources governance approaches and community participation 


\subsection{Human and wildlife conflicts around protected areas}

Protected areas are challenged by different forms of conflicts. In paper 4, I focus on crop raiding and compensation process among other forms of HWC. Understanding the local community perceptions regarding crop-raiding and how they are compensated is a crucial element is conservation process and the well-being of the local community.

Worldwide, human-wildlife conflicts are serious challenges for conservation initiatives by authorities and local communities around natural forests (Dickman, 2010; Hill, 2004 ). It has been recognized that it is impossible to conserve natural resources without taking into account the requirements of socio-economic development, particularly when local people live in close relationship with the natural environment on which they depend for their survival and well-being (Cantiani et al., 2016). There have always been tensions between conservationists and the community around national parks to encroach on the wild animal's habitat (Sitati et al., 2005) while the communities argue that wild animals damage their crops (Laudati, 2010). Much research has been conducted about human-wildlife conflicts. Among all form's human-wildlife conflict, cropraiding was identified as the type of human-wildlife conflict most problematic for farmers and agricultural societies as it causes substantial financial losses (FAO, 2005; Fungo, 2011; Harich et al., 2013).

In the process of minimizing tensions between park management and local communities who experience crop raiding, compensation programs were initiated. However, a universal inadequacy of all the compensation practices is that laws may not provide clear guidelines on how to estimate damage. Also, there are often no reliable methods to differentiate wildlife damage from other sources of damage including domesticated or feral animals. Since there are often no objective methods for damage assessment, the system depends upon individual judgments and therefore invites conflicts as well as corruption (Ogra \& Badola, 2008). It is also important to realize that both under-compensation and overcompensation can have harmful consequences for conservation. Under-compensation increases resentment and overcompensation can encourage human settlement and activities near the park (Bulte \& Rondeau, 2005). In addition, fears are expressed that inappropriate compensation can even worsen the problem. Therefore, a realistic assessment is extremely important in the long-term interest of conservation. 
For a compensation to be effective scholars like Bulte and Rondeau (2005) indicate that the compensation must be fair and should cover direct and indirect losses due to wildlife and it should not overcompensate for these damages. For this to happen there should be a realistic assessment of damages.

The package should encourage farmers' efforts in increasing agricultural productivity as well as in protecting it from damage using non-destructive means. The package benefits should be proportional to the efforts and alertness of the farmers. If lack of efforts or alertness get unduly rewarded, the farmer community is likely to become lazy and lose its productivity (Ogra \& Badola, 2008). In addition, the package should not leave any possible ways by which one individual can favor someone and gets bribed for it. The current need of validating damage claims is open to bribe driven favors. If the subjectivity in damage estimation is eliminated, and there are built in validation and cross-checking methods that do not depend upon a single person's judgment or certification, corruption can be identified. More on that, the package should require minimal policing, validation, and paperwork by the park management. If the entire system is based on and operated by the local community, there would be a minimum manpower demand on the park management.

In Paper 4, the findings reveal that most of the people living in the study area are victims of crop depredation and that there has not yet been effective strategy to minimize the frequency of crop raiding. Indeed, the compensation scheme and process seem not to work and is not effectively addressing human-wildlife conflicts due to the subjectivity and lack of fairness in assessing damages, expensive process on the side of the local communities. In fact, the study shows that the compensation scheme is still complicated and takes long to provide compensations in cases they are accepted. As a result, people affected by the phenomenon of crop raiding are complaining about socio-economic and livelihood losses that lead to the degradation of their relationship with park managers $^{6}$. In conclusion, mechanisms that promote fair compensation should be put in place to minimize human-wildlife conflicts.

\footnotetext{
${ }^{6}$ These paragraphs refer to aspects being published in paper 4 on crop raiding and compensation process
} 


\subsection{Conservation practices and challenges in Rwanda}

In Paper 1, 2, 3,4, and 5 conservation practices and challenges especially in Rwanda are discussed. Rwanda is a landlocked country, and its population is estimated at approximately 11,809,300 people according to the 2017 census (GoR, 2017; NISR, 2018). Rwanda's population density is the highest in Africa and it is estimated to be 467 people per square kilometer (GoR, 2017; NISR, 2012).

Most Rwandans in rural areas are engaged in subsistence agriculture and the natural resources such as forest, land, water, etc., stay vital to country individuals' occupations (NISR, 2012-EICV4, NISR, 2018-EICV-5). Many people in Rwanda who live in the adjacent protected areas with richest biodiversity are among the poorest; therefore, they rely on natural resources found in the area (Plumptre, 2012). Population and environment are linked together in such a way that the environment offer basic needs to the community and the extraction of resources at a high rate finally cause poverty $(\mathrm{GoR}, 2009)$. It is quite impossible to separate natural resources and the community.

Since 1998, Rwanda adopted a decentralization policy aiming at ensuring democratic governance, accountability and community participation in decision making. However, the level of participation of local communities is still low. Community participation is considered as one of the benefits of decentralization as local people play a big role in matters affecting them. However, participation remains only of policy kind and active participation through engaging local people in planning processes, community agenda prioritization and decision-making are all but missing (Imanishimwe et al., 2018; Munene Ndereba, 2017; Umuziranenge, 2019).

In Rwanda as in many countries in Africa, conservation approaches started with protectionism approach that ignored community knowledge and experiences in conservation and development process. With this approach local populations had no right to use their natural resources. This approach considered local people as ignorant destructors of natural resources. 
This old conservation approach was replaced by a new conservation approaches known as community-based conservation that includes local communities in the management of natural resources as a mean of reconciling conservation and development of people living around parks and other protected areas (Lele et al., 2010). However, in Rwanda this new conservation paradigm faced challenges related to the insufficient of natural resources base and rising population pressure.

Conservation challenges are not a new phenomenon in Rwanda. This is the reason why conservation goals constitute a cornerstone strategy for national economies and a guiding principle to comply with the county's vision for the achievement of sustainable development goals (Nibeza \& Tumusherure, 2015).

Another reason is that the conservation of natural habitats can create conflicts and negative relationships between conservation and human well-being including loss of access rights to natural resources and human-wildlife conflict (Dickman, 2010; Hill, 2004, Imanishimwe et al., 2018; Umuziranenge, 2019 [paper 4] ).

In order to reconcile the community needs and conservation of Rwanda forests and parks, the parliament voted an organic law $^{7}$ for the management and utilization of the parks and environmental resources. Article $20 \& 21$ of the organic law determining the management and utilization of forests and parks in Rwanda indicates that the responsibility to conserve and protect forests shall rest with any person who is in Rwanda. The population shall have the duty to conserve and protect forests and inform the nearest authorities of prohibited activities that may negatively affect proper forest management. In particular, those who live near the forest and who use it in accordance with the provisions of this law shall have the duty to conserve it and protect against anything that may damage it due to activities they carried out therein. In addition, public and private institutions as well as Non-Governmental Organizations shall collaborate in protecting forests against anything that may damage them. This organic law concerns particularly the three national parks specifically Volcanoes National Park in the north [host to the mountain gorillas], Akagera National Park [located in the eastern Province] and Nyungwe National Park in the south and west.

\footnotetext{
${ }^{7}$ Official Gazette $\mathrm{n}^{\mathrm{0}} 37$ of 16/09/2013: Procedures or a system of laws that form the basis of management and utilization of forests and parks in Rwanda
} 
The latter is the most recent, having been initiated in 2005 and around 360,000 population specifically fringe the recreation center.

As said above, this park has a substantial tract of mountain woodland and is rich in biodiversity. Guided strolls, chimpanzee following and recreational offices from Lake Kivu in this manner make this National Park to be special.

In the field of nature conservation, the organic law of 2005 for the management and utilization of protected areas and environmental resources involves local communities, local authorities, public and private institutions, and Non-Governmental Organizations. Given the great potential and the quick growth of eco-tourism industry in terms of revenues, many people including decision makers believe that the tourism sector can better help to achieve socio-economic development at local community level.

The new law and management scheme and related regulations were entrusted in Rwanda Development Board (RDB). The program assists local communities living adjacent to national parks in the construction of infrastructures like schools, dispensaries, water supply, food security and other income generating activities (Imanishimwe et al., 2018; Umuziranenge \& Muhirwa, 2017; Umuziranenge, 2019). Through the program, RDB supports projects that benefit development and welfare of local communities and involves them in conservation activities, including being park rangers and guides of the parks. The scheme is conducted through cooperatives starting from people who were involved in illegal activities from the past. From 2005 to 2018 , over US\$1.28 million has been spent on more than 158 community-based projects in three main national parks mentioned above.

Since 2005, the Office of Tourism and National Parks (ORTPN) current under the Rwanda Development Board with the support of the central government started a tourism income sharing plan, whereby $5 \%$ of the income earned in each park is gathered into a national pool and appropriated to the parks at various proportions. The distribution of that revenue is organized as follows: $40 \%$ to the Virunga National Park, 30\% to the Akagera National Park and 30\% to the NNP. 
To induce local population's ownership and benefit from those parks, RDB usually donates a portion of revenue from wildlife-based tourism to assist local communities living adjacent to national parks in the construction of infrastructures like schools, dispensaries, and water supply, food security and other income generating activities. It is the view of the authorities that, tourism revenue sharing brings good positive impact on community attitudes towards conservation of national parks. It may influence attitudes, values, and norms, and engender support for conservation of protected areas offset human wildlife conflict which impedes local support for national parks.

In Rwanda, the tourism revenue sharing approach was initiated for the following reasons: (1) the country has the highest population density in the region which is 467 people $/ \mathrm{km}^{2}$ (GoR, 2017; NISR, 2012), the majority of the population is engaged in subsistence agriculture, (3) natural resources such as forests, land and water are vital to country individuals' occupations (GoR, 2009) and (4) people living inside and around protected areas are among the poorest citizens and bring increased pressure and degradation (Imanishimwe et al., 2018; Masozera, 2002; Plumptre, 2012).

In Rwanda, the tourism income is administered towards traditional development activities like the construction of schools and health structures. Moreover, in Rwanda official statements on the socio-economic benefits of tourism only announce the turnover generated by ecotourism activities and the usual proportion of 5 to $10 \%$ which is often offered to local communities to finance common development activities. However, nothing is said about operating expenses, related tourism revenues, actual net profit, and the distribution of profits between stakeholders that is defined without the involvement of local communities. This obviously raises the problem of relevance of participation, transparency in management, equity in benefit sharing and environmental justice ${ }^{8}$. Therefore, there is a need of reshaping the policy in a way it involves all stakeholders in decision making process.

${ }^{8}$ This paragraph refers to aspects being published in paper 1,2,3 and 5 on tourism revenue sharing 


\section{Research Methodology and Methods}

This study aims to explore people's perceptions about community participation in natural resources management with the case study of Nyungwe National Park in Rwanda. In this part, I describe and explain the methodological processes and choices made regarding the empirical part of the study. I start by explaining the context of the study, the research design, and the related knowledge gap and, finally, the justification of the reason behind the adoption of qualitative approach in this study (3.1). In addition, I explain the sample (3.2) and sampling process (3.3), describe the data selection methods (3.4), methods of data analysis (3.5), ethical considerations (3.6) and quality control during the process (3.7).

\subsection{Research design}

The aim of the present study is to examine community participation in natural resources management in Rwanda by focusing on how the local community participate, how the local community is empowered to participate in natural resources conservation in the case of Nyungwe National Park in Rwanda. Specifically, the study aims to assess the community perceptions about types of activities in which the population is involved in the conservation of the park, the kinds of benefits they receive as neighbors of the park, how they are empowered economically and socially, how they are involved in the decision making process, and the kinds of challenges they face as neighbors of the Park and strategies they propose for a better conservation outcomes as key stakeholders. The above focus helps to understand key challenges that hinder community participation especially those living around protected areas and helps to understand the benefits that the local community receives as neighbors of protected areas in Rwanda. Different stakeholders have different views on these issues; thus, it is important to take into account various stakeholders, such as the local community living around protected areas of Nyungwe National Park, government Institution dealing with conservation activities (Rwanda Development Board RDB) and other stakeholders that are involved in conservation of natural resources around protected areas. 
So far, research conducted around protected areas in Rwanda are more quantitative. Lived experiences of local communities regarding their participation in the implementation of community conservation policies are missing in the context of scientific research in Rwanda (Imanishimwe et al., 2018; Kamuzinzi, Shukla \& Ndabaga, 2015; Tusabe \& Habyarimana, 2010). Much of the research conducted around protected areas in Rwanda focused on examining the socio-economic status of people living around Rwandan national parks (Plumptre et al., 2004; Bush et al., 2010), evaluating the community-based conservation around the Nyungwe National Park (NNP) (Rutebuka et al., 2012), examined perceptions of tourism revenue sharing impacts on Volcanoes National Park (Munanura et al., 2016), measured effectiveness, efficiency and equity in payments for ecosystem services (Martin et al., 2014), and evaluated forest dependence and its implications for protected area management (Masozera \& Alavalapati, 2004) (see as well chapter 2 of this synopsis).

For analyzing, how the social reality is shaped and maintained, or how people interpret their actions and experiences, qualitative approaches are appropriate (Blaikie, 2007; Khan, 2014; Rahman, 2017). Qualitative approach gives a voice to the population. In qualitative approaches a direct connection between researchers and the participants when collecting data, is possible (Ary et al., 2013). This reflection pushed me to choose a qualitative approach to assess local community perceptions regarding their participation and involvement in developmental projects regarding the protection of Nyungwe National Park.

Therefore, based on the nature of the topic and research questions (see chapter 1 as well) in this study, a qualitative approach was chosen (Savin-Baden \& Major, 2013, p.12-14; Silverman, 2014, p. 5). It focuses on understanding people's beliefs, perspectives, experiences, attitudes, opinions, perceptions about phenomena, situations, or issues (McMillan \& Schumacher, 2014). In addition, a qualitative approach is an appropriate method when exploring people's perceptions, attitudes and participation in conservation and park development (Claiborne, 2010). The main advantage with qualitative research is the ability to study and describe experiences and social phenomena (Silverman, 2006). 
For the reason that the study is mainly aiming to explain how people participate and understand their role and involvement in conservation of the park, a qualitative approach fits the purpose of the study as beliefs, experiences and perceptions can be effectively explored through open expression of participants in producing a broad description of participants' feelings, opinions, and experiences and interprets the meanings of their actions (Rahman, 2017). It seeks to understand and interpret more local meanings, recognizes data as gathered in a context and sometimes produces knowledge that contributes to more general understandings (Davidson \& Tolich, 2003).

It is concerned with meanings rather than reports and measures of behavior or internal cognitions, the use of inductive, theory-generating research (Silverman, 2006). In this regard, participants are given voices to express their own beliefs, their feelings, lived experiences and perceptions concerning their participation and role in the conservation of the Park. Thus, the knowledge is constructed from the context in which it was generated to discover the participants' inner experience, and to figure out how meanings are shaped through and in culture (Corbin \& Strauss, 2008; Rahman, 2017). This refers both to the context of data generation, such as an interview setting, and to the broader socio-cultural and political contexts of the research (Braun, \& Clarke 2013; Rahman, 2017; Roudgarmi, 2011).

According to Roudgarmi (2011) qualitative researchers study things in their natural settings, attempting to make sense or interpret phenomena in terms of the meanings people bring to them and produce hypotheses which can be checked using the quantitative methods. Furthermore, qualitative research design (interactive approach) has a flexible structure as the design can be constructed and reconstructed to a greater extent (Rahman, 2017; Maxwell, 2012). In paper 5, the methodology adopted relies on the interpretative and analytic synthesis of available literature on nature conservation. 
The local community is the social focus of this study, as they are placed as the change agents of the future in the policy, public debates, and the success of natural resources conservation in Rwanda. Their voices have not been considered and included to a large extent in research in many African countries including Rwanda; thus, they are included as key stakeholders in the present study. Furthermore, it is presumed that communities are significant actors in conservation process and will, thus, provide important views about their participation in the conservation process; key challenges and strategies to overcome them. The governmental institution RDB was included because they are decision makers and the primary actors in conservation of natural resources in Rwanda. Their views concerning what the local community gets as benefit and how they are empowered are important for understanding issues about local community conservation in Rwanda.

To achieve the objective of maximizing diversity, several professional groups were emphasized in this study including the local community, decision makers and other stakeholders (see table 4).

\begin{tabular}{|l|l|l|c|l|l|}
\hline Papers & Category of Stakeholders & \multicolumn{1}{|c|}{ Institutions } & $\begin{array}{l}\text { Number of } \\
\text { Participants }\end{array}$ & $\begin{array}{c}\text { Data collection } \\
\text { method }\end{array}$ & $\begin{array}{l}\text { Method of } \\
\text { Data Analysis }\end{array}$ \\
\cline { 1 - 5 } $\begin{array}{l}\text { Paper 1, 2, } \\
4\end{array}$ & Local communities & $\begin{array}{l}\text { Park's surrounding } \\
\text { Communities }\end{array}$ & 15 & $\begin{array}{l}\text { Primary data: } \\
\text { Semi-structured } \\
\text { interviews }\end{array}$ & $\begin{array}{l}\text { Content } \\
\text { analysis: data } \\
\text { coding, data } \\
\text { sorting, } \\
\text { generating } \\
\text { knowledge }\end{array}$ \\
\cline { 2 - 5 } & Decision makers & $\begin{array}{l}\text { Rwanda Development } \\
\text { Board }\end{array}$ & 3 & 2 & \\
\cline { 2 - 5 } & Conservation NGOs & $\begin{array}{l}\text { Wildlife Conservation } \\
\text { Society }\end{array}$ & 20 & $\begin{array}{l}\text { Primary data: } \\
\text { Questionnaire- } \\
\text { based survey }\end{array}$ & $\begin{array}{l}\text { Univariate } \\
\text { technique } \\
\text { Frequency } \\
\text { distribution }\end{array}$ \\
\cline { 2 - 5 } & Total & Household & 90 & $\begin{array}{l}\text { Secondary data: } \\
\text { Document } \\
\text { Analysis: review of } \\
\text { existing literature } \\
\text { and policies }\end{array}$ & \\
\hline Paper 5 & Local communities & & & & \\
\hline
\end{tabular}

Table 3: Summary of research methods according to the papers and category of respondents 


\subsection{Characteristics of the sample 9}

This research adopted a qualitative approach to gather the required primary data through semistructured interviews (see chapter 3.4.1 in detail). The data collection started in September 2018 until January 2019.

20 participants (refer to table 4) for interviews during data collection are from local communities, decision makers and conservation NGOs involved in tourism and conservation activities.

\begin{tabular}{|l|l|l|c|}
\hline \multicolumn{1}{|c|}{ Papers } & \multicolumn{1}{|c|}{ Category of Stakeholders } & \multicolumn{1}{c|}{ Institutions } & \multicolumn{1}{c|}{$\begin{array}{c}\text { Number of } \\
\text { Participants }\end{array}$} \\
\hline \multirow{3}{*}{ Paper 1, 2,4 } & Local communities & Park's surrounding Communities & 15 \\
\cline { 2 - 4 } & Decision makers & Rwanda Development Board & 3 \\
\cline { 2 - 4 } & Conservation NGOs & Wildlife Conservation Society & 2 \\
\hline
\end{tabular}

Table 4: Category of respondents

According to Larsson (2009), maximizing variation in qualitative research is relevant in studies in which a number of cases constitute the empirical basis. This importance of variation relates to the sample components rather than sample size. In the current study, variation was maximized through mixed samples in terms of stakeholders (local communities, decision makers and NGOS). These heterogeneous samples were useful to provide a wide range of perceptions about the meaning of community participation. It was presumed that the interviewed participants have different experiences and needs and require access to different types of services and support in relation to community participation in natural resources management. It was also presumed that such interviewed participants have sufficient understanding of community conservation goals and attempt to link them with their daily life.

\footnotetext{
${ }^{9}$ Specific to paper 1,2 and 4
} 


\subsection{Sampling techniques}

Theoretical sampling drawn from grounded theory is used due to the purpose of this study. Originally, grounded theory was developed as means of generating theories from empirical data (Charmaz, 2014; Glaser \& Strauss, 1967; Thornberg, Perhamus \& Charmaz, 2014). The choice of participants, data collection and analysis are done in parallel (Creswell, 2013; Flick, 2013; Glaser, 2009; Savin-Baden \& Major, 2013). In this process, the size of the sample is not fixed (SavinBaden \& Major, 2013; Silverman, 2014, pp. 62-63). Furthermore, there is a progressive comparative analysis along the process to outline similar and new data from participants (Glaser, 2009).

In the context of this study, characteristics or criteria of participants are determined to guide the process of sampling. According to Silverman, (2005), theoretical sampling means that participants are selected by virtue of having the characteristics relevant to the research questions. Therefore, through the process of data collection, the researcher ensures that characteristics of participants are being involved for that reason. In this study, gender, age, professional qualification and working experience, as well as living experience, are considered in the process of sampling (refer to table 5). Therefore, purposive and convenience sampling strategies (Thoernbeg \& Charmaz, 2014, p.156) are used to select participants. Participants were selected among others according to the characteristics or criteria set before. Moreover, convenience sampling was used when there is more than one participant who fulfils the requirements of being selected. For example, if there are two or more participants having the same characteristics, convenience sampling was used by selecting the participant who is available at the time of interview (Kumar, 2011, p.189; Taneja et al., 2011). 


\begin{tabular}{|c|c|c|c|c|c|c|c|c|c|c|c|c|c|c|c|c|c|c|c|c|c|}
\hline \multicolumn{2}{|c|}{$\begin{array}{l}\text { Sampling } \\
\text { criteria }\end{array}$} & $\begin{array}{l}\xi \\
\Omega\end{array}$ & 5 & $\underset{\Omega}{\Omega}$ & $\underset{\sigma}{\sigma}$ & $\tilde{N}$ & 5 & 5 & $\tilde{\omega}$ & 5 & 3 & $\underset{\sim}{\nabla}$ & $\underset{\underset{\omega}{\sigma}}{\underset{\varpi}{\sigma}}$ & ${ }_{\infty}^{5}$ & 5 & $\stackrel{5}{0}$ & 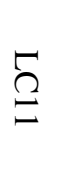 & $\frac{5}{2}$ & $\frac{5}{2}$ & $\stackrel{5}{2}$ & $\frac{5}{2}$ \\
\hline \multirow[t]{2}{*}{ Age } & $25-30$ & & & & $\mathrm{X}$ & & & & & & & & & & & & & & & & \\
\hline & $30-35$ & & & & & & & & & & & $\mathrm{X}$ & & & & & & & & & \\
\hline \multirow[t]{4}{*}{ Years } & $35-40$ & $\mathrm{X}$ & & $\mathrm{X}$ & & $\mathrm{X}$ & & & & $\mathrm{X}$ & & & $X$ & & & & $\mathrm{X}$ & & & & $\mathrm{X}$ \\
\hline & $40-45$ & & & & & & $\mathrm{X}$ & $X$ & & & & & & $\mathrm{X}$ & & & & & & $X$ & \\
\hline & $45-50$ & & $\mathrm{X}$ & & & & & & $\mathrm{X}$ & & & & & & & & & $\mathrm{X}$ & $\mathrm{X}$ & & \\
\hline & $\begin{array}{l}50 \text { and } \\
\text { above }\end{array}$ & & & & & & & & & & $X$ & & & & $\bar{X}$ & $\mathrm{X}$ & & & & & \\
\hline \multirow[t]{2}{*}{ Gender } & $\mathrm{F}$ & & & & & $\mathrm{X}$ & $X$ & $X$ & & & & & & $X$ & & & $\mathrm{X}$ & & $X$ & $\mathrm{X}$ & $X$ \\
\hline & $\mathrm{M}$ & $\bar{X}$ & $\mathrm{X}$ & $\bar{X}$ & $\mathrm{X}$ & & & & $\mathrm{X}$ & $\bar{X}$ & $\bar{X}$ & $\mathrm{X}$ & $\mathrm{X}$ & & $\bar{X}$ & $\mathrm{X}$ & & $\mathrm{X}$ & & & \\
\hline \multirow{3}{*}{$\begin{array}{l}\text { Working and } \\
\text { living } \\
\text { experience }\end{array}$} & $1-5$ & & & & $\mathrm{X}$ & & & & & & & $\mathrm{X}$ & & & & $\mathrm{X}$ & & & & & \\
\hline & $5-10$ & $\mathrm{X}$ & & & & & $X$ & & & & & & $X$ & & & & & & & $\mathrm{X}$ & \\
\hline & $10-15$ & & & $\mathrm{X}$ & & & & & & & & & & & & & & & & & \\
\hline \multirow[t]{2}{*}{ Years } & $15-20$ & & & & & $\mathrm{X}$ & & & & & & & & & & & $\mathrm{X}$ & & & & $\mathrm{X}$ \\
\hline & $\begin{array}{l}\text { Above } \\
20\end{array}$ & & $\mathrm{X}$ & & & & & $\mathrm{X}$ & $\mathrm{X}$ & $\mathrm{X}$ & $\mathrm{X}$ & & & $\mathrm{X}$ & $\bar{X}$ & & & $\mathrm{X}$ & $\mathrm{X}$ & & \\
\hline
\end{tabular}

Table 5: Characteristics of respondents (data base, used for paper 1, 2 and 4)

LC: $\quad$ Local Community

RDB: $\quad$ Rwanda Development Board

WCS: Wildlife Conservation Society 


\subsection{Data selection methods}

\subsubsection{Semi-structured interviews ${ }^{10}$}

Research questions are the basis of any research according to Mayring, (2014). It is why research questions guided all decisions in the context of the present study including the coding system, data collection, analysis, and interpretation. The research questions guide the development of the interview guide as well. The latter is developed by making sure that the major questions to be asked during the interview are valid to generate answer to research questions. Moreover, research questions orient the process of developing the deductive coding frame by looking at theoretical knowledge that scholars generated about the issue under investigation. Once the interview guide is ready, interviews are conducted. Interviews should start by general question introducing the interview and proceed with deep and open stimulation questions related to issue under investigation and end with another general closing question (Savin-Baden \& Major, 2013, pp. 364-368).

After deciding on the approach to be used in the study, I also had to choose the tool to be used for data collection that fits well the aim of the study. Interviews are a viable means of learning about peoples' views within qualitative research (Bryman, 2012). This is the same as with Patton's (2002) idea that the purpose of interviews is to allow one to enter into the interviewee's perspective. This means that interviews are the most adequate method to collect personally related data. Scholars show that interviews serve for studying individuals' views, understandings interpretations, experiences, perceptions (Mason, 2018, p.111). Semi-structured interviews are preferred to keep the flexibility to listen and answer to the people. This was also highlighted by Glaser on what he calls listening "with a big ear" to mean using all possible methods of interpretation to reach to your objective (Glaser, 2001, p. 175).

In the present study, the interview guide comprised only the entry questions, and the interviews questions are developed based on the input of the participants. Therefore, the above views from scholars guided the choice of data collection tool in the present study. Data collection was done using semi-structured interviews with open-ended questions to gather deep responses about people's experiences, perceptions, opinions, feelings, and knowledge (Patton, 2002).

${ }^{10}$ Method specific to paper 1,2 and 4 
I chose to adopt the use of semi structured interviews to allow the interviewees the opportunity to express their personal experiences or views in their own words, which in turn allows me to gain the interviewee's viewpoint (Paper 1, 2, 4).

Being open by means of pre-set questions with flexibility of asking more questions to get rich information (Mason, 2018, p. 111; Savin-Baden \& Major, 2013, p.358) related to the thinking and experiences of participants, semi-structured interviews fit to explore lived experiences of people about their role, participation and involvement in conservation of the Park. Semi-structured interviews were conducted to collect data from respondents' views regarding the understanding of community participation in natural resources management around protected areas of Nyungwe National Park like understanding of how the communities are empowered to participate in natural resources management.

Semi-structured interviews were preferred because they offer maximum flexibility to pursue information in the direction that appears to be appropriate, depending on what emerges from the interviewee during the conversation (Patton, 2002). Such flexibilities pushed me to select semistructured interviews as a method of data collection in the present study. In addition, semistructured interviews are useful to make respondents be open enough and help me to reflect upon the answers as well as to rearrange questions and add new questions. Thus, in the present study, the interview guide comprised only the entry questions, and the interviews developed to a large extent based on the input of the participants. In this study apart from the introductory part of interview, the interviewer started to ask participants general questions about how they see their life as neighbors of the park, the role of the park in their life and deep questions for gathering rich data were developed in line with the research questions the study wishes to answer (refer to table 6).

As the first question is related to the self-understanding, the specific questions were set to ask about participants' self-understanding of their involvement in the conservation of the park as neighbors of the park. For instance, the following questions were asked:

- What is your role in the conservation of the park? (Used for paper 1 and 2)

- What are the benefits you get as neighbor of the park? (Used for paper 1,2, and 3)

- When there is something to be decided on, can you share with me how is it done? (Used for Paper 1, 2, 3, and 4)

- What are the challenges do you face as neighbor of the park? (All papers) 
- What are the strategies you can propose to overcome the challenges you face? (All papers) After the interview guide is done then the process of collecting data is initiated by first selecting participants according to the identified criteria and characteristics. The identification of participants to be interviewed is progressively done by finding the contact of participant fulfilling the criteria of the sample (Savin-Baden \& Major, 2013, p. 316).

Before starting the interview process, the purpose of the research was explained to the participants in the orientation of getting knowledge and learning from their experiences related to the topic under investigation. The purpose of this introduction is to build relationship with the participant. On the beginning of the interview, I started by introducing myself to the participant, explaining the purpose of the research and what I expects from her or him as indicated in guidelines of Theoretical Sampling (Glaser, 1978). I also explained the ethical aspects including free participation and right to withdraw, ensuring confidentiality and anonymity of data during data analysis. The participant was allowed to ask questions where she /he need clarification about the interview.

Even if the interview guides orient the process of interview, the discussion does not always follow the pre-determined order as prescribed. Rather, it is done in a flexible order where the researcher has to ask to follow up and searching questions basing on the answers of the interviewee (SavinBaden \& Major, 2013, p. 365). Therefore, questions were not always asked in the same order. The order mostly depended on interviewee's answers. Interviews were recorded by means of audiorecording instrument. Moreover, the interviewer carefully listens and observes how participant shares his / her experiences and views. The following table relates research questions and interview guide. 


\begin{tabular}{|c|c|c|}
\hline Research questions & Open stimulation & Check/list on specifics \\
\hline $\begin{array}{l}\text { How do local community perceive } \\
\text { and understand participation in } \\
\text { conservation and management of } \\
\text { avungen }\end{array}$ & $\begin{array}{l}\text { Tell me how is your life here as } \\
\text { neighbor of the Park? }\end{array}$ & $\begin{array}{l}\text { Tell me, what are you doing here? } \\
\text { Can you share with me kinds of } \\
\text { activities are you involved in? }\end{array}$ \\
\hline \multirow{3}{*}{$\begin{array}{l}\text { What kinds of activities are local } \\
\text { communities involved in? What are } \\
\text { the roles played by the local } \\
\text { community in the conservation of } \\
\text { the park? }\end{array}$} & $\begin{array}{l}\text { How long have you been living } \\
\text { here? }\end{array}$ & \\
\hline & \multirow{2}{*}{$\begin{array}{l}\text { Which role does the park plays in } \\
\text { your life? } \\
\text { Tell me about change in life after } \\
\text { this NNP was recognized as NNP. } \\
\text { In your views are there any } \\
\text { problems that people around NNP } \\
\text { are facing? }\end{array}$} & $\begin{array}{l}\text { Share with me how you benefit as } \\
\text { neighbor of the park? }\end{array}$ \\
\hline & & $\begin{array}{l}\text { A lot of things have to be decided } \\
\text { here, tell me how this is done? Can } \\
\text { you share with me how the process } \\
\text { is done? }\end{array}$ \\
\hline & \multirow{2}{*}{$\begin{array}{l}\text { It seems that you have been living } \\
\text { here for so long and you are older } \\
\text { than the park; tell me how was } \\
\text { your life before? }\end{array}$} & \\
\hline \multirow[t]{2}{*}{$\begin{array}{l}\text { What are the challenges that face the } \\
\text { local community in the process of } \\
\text { the Park conservation? } \\
\text { What are the strategies or wishes to } \\
\text { minimize the challenges faced? }\end{array}$} & & $\begin{array}{l}\text { Tell me what are the challenges } \\
\text { you face as neighbor of the park } \\
\text { management? }\end{array}$ \\
\hline & $\begin{array}{l}\text { I have heard that people around } \\
\text { the park benefit from it; tell me } \\
\text { your experience and role that the } \\
\text { park plays in your life? }\end{array}$ & $\begin{array}{l}\text { With your experience tell me what } \\
\text { could be done or your wishes to } \\
\text { minimize the challenges you face } \\
\text { here as neighbor of the park. }\end{array}$ \\
\hline
\end{tabular}

Table 6: Interview guide

The participants had the choice either to be interviewed in Kinyarwanda, English, or French. Interviews in Kinyarwanda or French were translated into English. All participants chose to be interviewed in Kinyarwanda.

During the interviews, a digital voice re-cording was made together with memos taking, which helped me to capture some expressions that would provide necessary information related to the research. Data were taken in forms of records and were conducted in Kinyarwanda. Audio recorded were transcribed, translated in English, and subjected to qualitative analysis. The duration of each interview was 30 to 45 minutes, depending on how much conversation each question incited. 
For the processing of the data, at the end of each interview, transcription, translation, and coding follow. It is important to note that, in line with theoretical sampling; each interview is transcribed, translated, and coded before proceeding for the next one until the saturation is reached. In order to produce knowledge, a categorization process was done (Roudgarmi, 2011; refer to chapter 3.5.2 in detail).

\subsubsection{Mixed method ${ }^{11}$}

In paper 3 a mixed method approach that included qualitative and quantitative techniques was used for data collection and analysis. According to Mikkelsen (2005), mixed methods research design has many advantages. Mixed-methods research approach provides an inclusive result since the findings from one method can help inform the other method (Creswell, 2013; Creswell \& Plano Clark, 2007).

The research used quantitative approach to capture measurable data of community perceptions of and participation in NP and tourism. Hence, quantitative research can produce results that are statistically reliable (Nykiel, 2007) and the statistical significance of relationships and difference can be determined. Thus, a set of household questionnaires were used to assess the impact of ecotourism on local community' development around Nyungwe National Park. The questionnaire was reflecting the benefits that people get and the challenges they face as neighbors of the park.

The questionnaire was designed using mainly closed-ended questions. The contents of the questionnaire were divided into four sections, each composed of different measuring instruments. Section I included questions on socio-demographic characteristics of the respondents, Section II focused on the knowledge of respondents towards Nyungwe national Park and its associated tourism activities, Section III inquired about tourism revenue sharing and degree of participation and involvement in ecotourism, while Section IV centered on attitude and perception towards impact of ecotourism as incentive for conservation of Nyungwe National Park (refer to paper 3). The following table 7 provides the items of questionnaire.

11 This method is specific to paper 3 


\begin{tabular}{|c|c|}
\hline Questions & Possible answers \\
\hline $\begin{array}{l}\text { 1. Demographic } \\
\text { characteristics }\end{array}$ & $\begin{array}{l}\text { a. age: } \\
\text { 1. } 25-35 \\
\text { 2. } 36-45 \\
\text { 3. } 46 \text { and above } \\
\text { b. Gender: } \\
\text { 4. female } \\
\text { 5. male } \\
\text { c. occupation: } \\
\text { 1. Farmer } \\
\text { 2. Student } \\
\text { 3. Business } \\
\text { 4. Government employee }\end{array}$ \\
\hline $\begin{array}{l}\text { 2. Knowledge about the } \\
\text { park }\end{array}$ & $\begin{array}{l}\text { Are there any Problems that people cause to NNP (problems related to } \\
\text { its safety and natural status)? (1) Yes (2) No b) } \\
\text { If yes what are they? } \\
\text { 1. Burning the forest } \\
\text { 2. Cutting trees } \\
\text { 3. Mining inside the park } \\
\text { 4. Killing wild animals } \\
\text { Are there any problems that people around NNP face? (1) Yes (2) No } \\
\text { If yes what are they: } \\
\text { 1. Crop raiding } \\
\text { 2. injury } \\
\text { How often wild animals raid your crops? } \\
\text { (1) Frequently (e.g., every day) (2) Less frequently (e.g., twice a week) } \\
\text { (3) Rarely (e.g., once a month) (4) Never } \\
\text { a) Have you ever been compensated for crop damages caused by wild } \\
\text { animals from NNP? } \\
\text { (1) Yes (2) No b) If yes how? If no, why? }\end{array}$ \\
\hline $\begin{array}{l}\text { 3. Knowledge about } \\
\text { tourism revenue sharing } \\
\text { and degree of } \\
\text { participation and } \\
\text { involvement in } \\
\text { ecotourism }\end{array}$ & $\begin{array}{l}\text { Are there tourism activities in this village? } \\
\text { (1) Yes (2) No } \\
\text { - If yes do you benefit from it? } \\
\text { (1) Yes (2) No } \\
\text { - If yes what do you benefit? } \\
\text { 1. Job } \\
\text { 2. Income generating activities } \\
\text { 3. Infrastructure } \\
\text { 4. Conservation awareness } \\
\text { 5. Improving living standards } \\
\text { Do you know any projects that NNP management has initiated to } \\
\text { improve local livelihoods? } \\
\text { (1) Know (2) Don't know }\end{array}$ \\
\hline
\end{tabular}




\begin{tabular}{|c|l|}
\hline & $\begin{array}{l}\text { Do you know anything about tourism revenue sharing } \\
\text { (1) Know (2) Don't know? } \\
\text { Have you ever been consulted to discuss/decide on park management } \\
\text { and or how to share benefits or projects NNP should support? (1) } \\
\text { Consulted (2) Not consulted }\end{array}$ \\
\hline $4 . \quad$ attitude and perception \\
$\begin{array}{l}\text { towards impact of } \\
\text { ecotourism as incentive } \\
\text { for conservation of } \\
\text { Nyungwe National Park }\end{array}$ & $\begin{array}{l}\text { Do you think that receiving tourism-related benefits from NNP can help } \\
\text { stop illegal activities to NNP? } \\
\text { (1) Stop illegal activities (2) Will not stop illegal activities }\end{array}$ \\
\hline
\end{tabular}

Table 7: Household questionnaire

Source: own design

Open questions through semi-structured interviews were conducted with key respondents of both governmental and non-governmental organizations that are directly involved in conservation of Nyungwe National Park.

Before questionnaires were administered in communities around NNP, the village heads were visited, and they were asked for permission to carry out the survey in their villages. The village head gave an approximate number of households in their villages and this helped in distribution of questionnaire in each village. Household questionnaires were administrated face-to-face to alleviated potential issues with literacy and familiarity with survey procedures. The researcher and research's assistant walked along the roads in a village, the first household in the village would be approached and invited to participate. After which the next household would not be approached while the third household would be invited to participate until 90 households are covered. For example, in a village, the village number 1 was approached, and the next household was the household number $3(1,3,5,7 \ldots \ldots \ldots \ldots \ldots . . .90)$.

In terms of incentives, each household that participated in providing information was given 2 soaps equivalent to $1000 \mathrm{FRW}$. The budget used to by soaps was calculated from my monthly salary.

The statistical technique used for analysis is univariate. The univariate technique used frequency distribution for data analysis using Excel format. Frequency distribution and the corresponding responses were presented in graphical formats (refer to paper 3 ). 


\subsubsection{Document analysis: Secondary data ${ }^{12}$}

In paper 5 the method of collecting data relied on a broad exploration and an interpretative of currents policies and practices of conservation in the world and in Africa, a critical analysis of conservation policies and practices in Africa and an identification of inconsistencies, contradictions and uncertainties that undermine the effectiveness of conservation in Africa as well as the propositions of strategies to ensure the effectiveness and sustainability of conservation on the continent. The study used the following documents and data sources: (i) international conventions and policy documents on nature conservation, (ii) theoretical bibliographic data and scientific publications on nature conservation, and (iii) quantitative and qualitative empirical data from periodic reports of international and national institutions and services specialized in nature conservation (refer to the following table 8).

\begin{tabular}{|l|l|}
\hline Category of document & Number of documents \\
\hline International union for convention of nature documents & $\begin{array}{l}\text { International Union for Conservation of Nature } \\
(\text { IUCN): } 3\end{array}$ \\
\hline Scientific publications on natural resources conservation & Scientific Publications: 6 \\
\hline $\begin{array}{l}\text { Quantitative and qualitative empirical data from periodic } \\
\text { reports of international and national institutions and } \\
\text { services specialized in nature conservation. }\end{array}$ & $\begin{array}{l}\text { Fonvention on Biological Diversity (CBD): } 3 \\
\text { Organisation for Economic Co-operation and } \\
\text { Development (OECD): 1 }\end{array}$ \\
\hline
\end{tabular}

Table 8: Category and number of documents used for document analysis method in paper 5

The use of secondary data is important for case study analysis because it helps to corroborate and increase evidence from other sources (Jennings, 2001). In all papers, secondary data was obtained through an extensive review of literature relating to a variety of topics, including, but not limited to, community-based tourism; community perception of and attitude towards national parks and tourism; development and management of national parks. Academic journals, books, consultant reports and newspaper articles were included.

\footnotetext{
${ }^{12}$ Method specific to paper 5
} 
Likewise, secondary sources, such as legislation, reports, management plans, statistical data, and other related literatures were collected in the offices visited for primary data. In this research, documents analyzed provided basic information that helped the researcher in developing the research framework in different papers. Table 9 illustrates 4 themes and memos considered while analyzing secondary resources especially in paper 5 .

\begin{tabular}{|c|c|c|c|c|}
\hline Theme & $\begin{array}{l}\text { Theme 1: Conservation } \\
\text { policies and practices }\end{array}$ & $\begin{array}{l}\text { Theme 2: Gaps between } \\
\text { standards and field } \\
\text { practices }\end{array}$ & $\begin{array}{l}\text { Theme 3: Challenges } \\
\text { in natural resources } \\
\text { conservation }\end{array}$ & $\begin{array}{l}\text { Theme 4: Strategies } \\
\text { for a successful } \\
\text { conservation model }\end{array}$ \\
\hline Memo 1: & $\begin{array}{l}\text { Sacred forests and } \\
\text { community regulations }\end{array}$ & $\begin{array}{l}\text { Break of the historical } \\
\text { human-nature through } \\
\text { community regulations }\end{array}$ & $\begin{array}{l}\text { Increase demand for } \\
\text { agriculture and } \\
\text { livestock land }\end{array}$ & $\begin{array}{l}\text { Conservation practices } \\
\text { should balance and } \\
\text { achieve ecological } \\
\text { goals as well as socio- } \\
\text { economic goals }\end{array}$ \\
\hline Memo 2: & $\begin{array}{l}\text { Creation of protected } \\
\text { areas }\end{array}$ & $\begin{array}{l}\text { Violation of the interests } \\
\text { and dignity of indigenous } \\
\text { peoples and alteration of } \\
\text { traditional way of life }\end{array}$ & $\begin{array}{l}\text { Lack of fair } \\
\text { compensation }\end{array}$ & $\begin{array}{l}\text { A fair compensation } \\
\text { system should be put } \\
\text { in place }\end{array}$ \\
\hline Memo 3: & $\begin{array}{l}\text { Fortress conservation } \\
\text { and social exclusion }\end{array}$ & $\begin{array}{l}\text { Food pantries surrounded } \\
\text { by hunger }\end{array}$ & $\begin{array}{l}\text { Rapid population } \\
\text { growth }\end{array}$ & $\begin{array}{l}\text { Participation of the } \\
\text { local community in the } \\
\text { management and } \\
\text { governance should be } \\
\text { enhanced in the favor } \\
\text { of the local } \\
\text { community }\end{array}$ \\
\hline Memo 4: & $\begin{array}{l}\text { Extension of national } \\
\text { networks of protected } \\
\text { areas on the continent }\end{array}$ & $\begin{array}{l}\text { Abandonment of ritual } \\
\text { practices }\end{array}$ & Instability of laws & $\begin{array}{l}\text { Development of } \\
\text { domestic tourism }\end{array}$ \\
\hline Memo 5: & Tourism promotion & $\begin{array}{l}\text { Increasing illegal } \\
\text { exploitations and } \\
\text { continued degradation of } \\
\text { natural ecosystems that } \\
\text { have traditionally been } \\
\text { well managed and } \\
\text { safeguarded }\end{array}$ & $\begin{array}{l}\text { Implementation } \\
\text { agencies lack financial } \\
\text { capacity and autonomy } \\
\text { to take decisions }\end{array}$ & \\
\hline Memo 6: & $\begin{array}{l}\text { Integration between } \\
\text { conservation and } \\
\text { development }\end{array}$ & Socio-economic losses & $\begin{array}{l}\text { Dominance of centered } \\
\text { and bureaucratic } \\
\text { governance approach }\end{array}$ & \\
\hline Memo 7: & Participatory approach & Social conflicts & $\begin{array}{l}\text { Lack of management } \\
\text { goals and plans }\end{array}$ & \\
\hline Memo 8: & $\begin{array}{l}\text { Payment for ecosystem } \\
\text { services }\end{array}$ & $\begin{array}{l}\text { Lack of consensus on } \\
\text { which of human } \\
\text { activities should be } \\
\text { permitted in national } \\
\text { parks }\end{array}$ & $\begin{array}{l}\text { Lack of transparency in } \\
\text { management, equity in } \\
\text { benefit sharing }\end{array}$ & \\
\hline Memo 9: & $\begin{array}{l}\text { Compensation } \\
\text { mechanisms }\end{array}$ & $\begin{array}{l}\text { Ecotourism got little } \\
\text { socio-economic impact } \\
\text { in many countries }\end{array}$ & $\begin{array}{l}\text { Lack of sufficient } \\
\text { funding }\end{array}$ & \\
\hline Memo 10: & & & $\begin{array}{l}\text { Persistence of human- } \\
\text { wildlife conflict }\end{array}$ & \\
\hline
\end{tabular}

Table 9: Illustration of themes and memos for secondary data analysis 


\subsection{Data Analysis}

The purpose of the present study is to explore people's perceptions about participation in natural resources management. With semi-structured interviews, participants are free to express their understandings and experiences about their participation, their involvement in decision making process, their roles and challenges they face as well as strategies to overcome those challenges. Therefore, subjective theories can be found by analyzing meanings attributed to interactive participation, bottom-up decision-making process, socio-economic participation from what participants say. With this regard, qualitative content analysis is an appropriate method for data analysis of the semi-structured interviews.

\subsubsection{Preparation of the interviews}

Among the methods or approaches in qualitative data analysis, there is coding. This refers to the narrow down of big sets of data into codes. This means to find in a text of interview a code that groups a number of elements or statements under one concept, in order to make a limited number of codes (or categories). In this study, a content analysis method is used to interpret the data of interviews.

Firstly, each interview is transcribed, translated, and then coded before proceeding for the following interview. Transcription or representation of audible data into written form is an interpretive process which involves making judgments and is therefore the first step in analyzing data (Bailey, 2008). Though transcription does not fully capture the whole interview, it is necessary to make sure that it is done in a way that it captures the most important message conveyed during the interview (Mayring, 2014, p. 43). Therefore, decisions about transcribing are guided by the methodological assumptions underpinning a particular research project. This means that the purpose of the research questions and the level of transcription should complement the level of the analysis (Trippas et al. 2017). In this study, verbatim transcription was used. Verbatim protocol is a system of transcription whereby the researcher writes word-by-word (Kowal \& O'Connell, 2014, pp.72-74; Mayring, 2014, p.45). In the process of verbatim transcription, clean transcription was used (refer to table 10). It captures the fundamental meaning behind spoken statements by removing slang, grammatical errors, or misuse of words that do not contribute to the primary message or research questions.

In some interviews it was necessary to paraphrase a statement so that it still conveys the same idea but in a more concise way to help the reader to easily understand the message. 
With this system, the transcript primarily reflects the content and message conveyed by interviewee that interests the researcher and the reader. Due to the purpose of this study, I use cleaning verbatim protocol to get technical data or information and therefore I cleaned up the transcripts so that the reader might read them easily. I developed the coding rules and guidelines (refer to table 10) that could help me systematically organize and then analyze textual data and they could help to achieve a high level of certainty that transcripts were generated systematically and consistently (McLellan, MacQueen, \& Neidig, 2003). Each interview was transcribed and analyzed until the saturation point was reached.

\begin{tabular}{|l|l|l|l|}
\hline Included & Not included & Pauses & Interruptions \\
\hline $\begin{array}{l}\text { - Everything that is said on } \\
\text { the recording with minor } \\
\text { paraphrasing (if needed). }\end{array}$ & $\begin{array}{l}\text { Grammatical errors, } \\
\text { fillers (ums, uhs, you } \\
\text {-Abbreviations were } \\
\text { written as said, such as }\end{array}$ & $\begin{array}{l}\text { For pauses } \\
\text { more than 2 } \\
\text { sn- In- In fact), false } \\
\text { seconds add } \\
\text { starts (incomplete }\end{array}$ & $\begin{array}{l}\text { For interruptions use } \\
\text { a short hyphen (-) }\end{array}$ \\
Development Board". & $\begin{array}{l}\text { sentences), repetitions, } \\
\text { non-verbal } \\
\text { communication, external } \\
\text { sounds and ambient } \\
\text { sounds are cleaned up }\end{array}$ & & \\
& & \\
\end{tabular}

Table 10: Clean verbatim protocol

\subsubsection{Data Analysis: Coding and Categorization}

The transcripts analysis started by developing a coding system that serves as a tool of coding and analysis. To develop the coding system, I referred to a wide literature on community participation in natural resources management and environmental justice. I have used them to develop a deductive coding system based on existing literature and my research questions about people' selfunderstanding of their participation and involvement in the protection of the park, their roles, their involvement in decision making processes and the challenges they face basing on their own experiences. Categories, sub-categories as well as sub-sub-categories are named and defined to guide the coding of interviews (Mayring, 2014, pp. 95-98; Schreier, 2014, p. 89). Deductive coding serves as flexible and open system for analyzing transcripts by using software. 
The use of software in qualitative data analysis is traced back in the mid-1980s when questions about the validity and the generalizability of findings obtained with qualitative methods attracted broader attention (Flick, 2013).

In this study, the software MAXQDA was used (Kuckartz, 2010). On the one hand deductive codes were incorporated in software MAXQDA to make the coding process easier, promote transparency and presentation of the unstructured nature of the data. On the other hand, inductive codes that were coming out as new information from interviews were also incorporated in the coding system. In the phases of familiarizing with data, generating initial codes, searching for themes, reviewing themes, defining, and naming themes and producing the report, an inductive and deductive analysis was conducted to identify existing patterns (Kennedy \& Thornburg, 2018). Codes assigned to different segments of the transcript of each interview are integrated into the existing coding system. As the latter is open, new inductive codes are generated from data to facilitate the progressive revision of the coding frame. Once the coding system is ready, the coding of interview follows.

The coding process starts by carefully reading the transcript, analyze it and extracting the excerpts or passages corresponding to research questions (Mayring, 2014, p. 66). In qualitative content analysis, coding the interview refers to the process of assigning segments of texts to the categories of the coding system (Schreier, 2014, p. 171) (known as deductive codes) and incorporating new categories from the data in the existing coding (Glaser, 1978; Mayring, 2014, pp. 97, 104) (known as inductive codes).

The use of deductive and inductive codes in this study is motivated by the fact that there is already knowledge existing on community participation and there is knowledge that may come out during the interview. Therefore, each interview is coded, and the process continues until the saturation point where no new codes are being generated from interviews. Through the process of coding and revising the transcribed texts, I continually made memos of important ideas that were identified in the data set to use them in presentation and discussion of results (Thornberg \& Charmaz, 2014, p.163). After the saturation point, the next step was to generate results of the study. During the analysis after a certain number and set of concepts are chosen for coding. 
For example, when coding for existence, "employment" would only be counted once, no matter how many times it appeared. But when coding for frequency, the number of times "employment" appears in a text is indicative of its importance. Step by step, a complete coding system was produced. In this study, I researched for possible underlying meanings and patterns across the coding system. This means that the groupings were carefully revised and counterchecked against the entire coding system to ensure that the correct meanings were sustained.

To obtain a clear image of the groupings, I generated a brief description of each grouping along with supported data extracts (refer to table 11). This helped me to clearly see the critical aspects of each grouping and the commonalities as well as differences between the different groupings. I then made a reduced version of categories that combined the former groupings with commonalities together to generate a common meaning. The underlying central meaning was used as a basis to name the categories. For example, in article one and two, a top-down approach, centered and people-oriented approach, integration of the local community were combined under the main category of community conservation approaches. The other categories like economic benefits (employment, jobs, infrastructures development like roads, health centers, schools and income generating projects), social benefits (ecological services such as water, clean air, climate regulation, social activities such as trainings and education programs), information exchange and others were formed under the category of types of participation.

In all articles, conflicts such as crop raiding were coded under the category of challenges that the local community neighboring the park face. In paper 4, delay of compensation, lack of standards, little compensation was coded under the code of complicated compensation process under the main category of challenges that face the local community in Park neighboring areas. Initiatives such as tourism revenue sharing, revolving fund, compensation fund were coded under the category of Government strategies for successful community conservation projects in the region (all articles). Fencing the Park and collective guarding system was coded as local community wishes or strategies for a successful community conservation program (see table 11). 


\begin{tabular}{|c|c|}
\hline Categories and sub-categories & Memo \\
\hline \multicolumn{2}{|l|}{$\begin{array}{l}\text { Community participation approaches (governance } \\
\text { system) }\end{array}$} \\
\hline top-down approach, coercive participation & $\begin{array}{l}\text { - lack of community participation, participation } \\
\text { through representation, } \\
\text { - dominance of RDB in governance of the park, } \\
\text { - passive participation of the local community by being } \\
\text { told what has been decided or already happened, } \\
\text { through representatives }\end{array}$ \\
\hline partnership approach & $\begin{array}{l}\text {-The government and the local community work } \\
\text { together. } \\
\text { - Active participation of the local community in all } \\
\text { processes, information exchange }\end{array}$ \\
\hline bottom-up approach, spontaneous participation & $\begin{array}{l}\text { - local communities are actively involved in } \\
\text { governance of the park, } \\
\text { - involved in the decision-making process, } \\
\text { - people-centered approach }\end{array}$ \\
\hline \multicolumn{2}{|l|}{ Form of participation } \\
\hline Participation by incentive & $\begin{array}{l}\text { Employment/jobs: trails clearing carry tourist's } \\
\text { luggage... }\end{array}$ \\
\hline Functional participation & $\begin{array}{l}\text { Firefighting, joint patrol, information exchange } \\
\text { through meetings, working with researchers, raising } \\
\text { awareness to help decision makers achieve their goals }\end{array}$ \\
\hline Passive participation & Local community receive only information \\
\hline Active participation & The local communities are fully involved \\
\hline \multicolumn{2}{|l|}{ Level of participation } \\
\hline Cooperative & $\begin{array}{l}\text { women's handcraft cooperative, bee-keepers } \\
\text { cooperative, ex-poachers, clubs }\end{array}$ \\
\hline Information exchange & Through meetings, media, \\
\hline \multicolumn{2}{|l|}{ Area } \\
\hline economic benefits & $\begin{array}{l}\text { job, income generating activities, infrastructure } \\
\text { development (schools, health centers, roads, markets), } \\
\text { equipment, loans (distributive justice) }\end{array}$ \\
\hline decision making & Procedural Justice \\
\hline bottom-up & $\begin{array}{l}\text { Involvement of the local community in decision } \\
\text { making process }\end{array}$ \\
\hline top-down & $\begin{array}{l}\text { - Involvement of the local community through } \\
\text { representation, } \\
\text { - only receiving information, } \\
\text { - lack of the local community in strategic meetings, } \\
\text { - their voices are not heard, } \\
\text { - domination of RDB in decision making process. }\end{array}$ \\
\hline social benefits & $\begin{array}{l}\text { Education, training, awareness raised, clean air, rain, } \\
\text { medicinal plants, ecological services }\end{array}$ \\
\hline \multicolumn{2}{|l|}{ Challenges face the community in participation } \\
\hline lack of skills in writing competitive projects & Training received are not enough \\
\hline low living condition and lack of resources (new) & $\begin{array}{l}\text { - poor, } \\
\text { - relying on subsistence agriculture, } \\
\text { - grasses for cattle, grazing space, } \\
\text { - not allowed to collect medicinal plants and other } \\
\text { resources inside the Park }\end{array}$ \\
\hline complicated lending process & high interest rate, lack of collateral \\
\hline $\begin{array}{l}\text { crop raiding and perception about compensation } \\
\text { process (new) }\end{array}$ & $\begin{array}{l}\text { - crop loss, } \\
\text { - involvement of kids in guarding process, } \\
\text { - hunger, } \\
\text { - socio-economic losses, }\end{array}$ \\
\hline
\end{tabular}




\begin{tabular}{|c|c|}
\hline & $\begin{array}{l}\text { - injury, and complicated compensation process: } \\
\text { process too long, not fair, no clear standards, pays } \\
\text { little. } \\
\text { - The process is expensive, abandon of compensation } \\
\text { claims, loss of compensation files, and subjectivity by } \\
\text { visual assessment. } \\
\text { - main foods raid: cabbage, maize } \\
\text { - main raiders: monkeys, baboons }\end{array}$ \\
\hline transboundary insecurity (new) & $\begin{array}{l}\text { Threaten the wellbeing of the local community, disturb } \\
\text { tourism activities }\end{array}$ \\
\hline \multicolumn{2}{|l|}{ Challenge faced by the Government } \\
\hline $\begin{array}{l}\text { Insufficient funds and grants } \\
\text { Human-wildlife conflicts } \\
\text { Illegal activities } \\
\text { Transboundary insecurity }\end{array}$ & $\begin{array}{l}\text { - crop raiding } \\
\text { - tree cutting, burning, } \\
\text { - threaten conservation initiatives, } \\
\text { - decrease tourism income }\end{array}$ \\
\hline \multicolumn{2}{|c|}{\begin{tabular}{|l|l} 
Corruption & \\
\end{tabular}} \\
\hline \multicolumn{2}{|c|}{ Strategies for a successful community participation (local community wishes) } \\
\hline Collective guarding system (new) & Guarding cooperatives \\
\hline increase collaboration and partnership approach (new) & active participation \\
\hline improving living condition & continuous support, more jobs, satisfying basic needs \\
\hline \multicolumn{2}{|l|}{ fencing the park (new) } \\
\hline ease and improve the process of compensation (new) & ease and improve the process of compensation (new) \\
\hline \multicolumn{2}{|l|}{ Government strategies } \\
\hline stakeholder's collaboration & RDB, WCS, local NGOS, \\
\hline \multicolumn{2}{|l|}{ Continuous training and awareness } \\
\hline environmental protection & $\begin{array}{l}\text { - Raising awareness, } \\
\text { - education programs, } \\
\text { - communication through radios, } \\
\text { - Umuganda: community activities }\end{array}$ \\
\hline financial support & $\begin{array}{l}\text { - tourism revenue sharing, } \\
\text { - revolving funds, } \\
\text { - financial institution, } \\
\text { - compensation fund } \\
\end{array}$ \\
\hline
\end{tabular}

Table 11: Categorization

\subsection{Ethical consideration}

Ethical considerations relevant to the articles that constitute this thesis have been discussed in each study and are only referred to in general in this section.

All along the data collection, principles of informed consent and respect for invasion of privacy were taken into consideration (Bryman, 2008). Rights and freedom of participants were respected. During every interview, the researcher and researcher's assistant briefed the participants about the aim of the research (Mack, 2005, p.10-11), the possible benefits of the research. Respecting autonomy by allowing participants to decide whether they participate or not in the research was given. The researcher also clearly stated that the interviews would be audio recorded to keep eye contact and not to forget or miss key information. 
It was clear that participants had the right to decline to participate and withdraw from the study irrespective of the extent of data collected. The researcher clearly informed the participants that they were free to request clarification at any moment and would receive answers. The researcher further clarified that their true names were not necessary in handling the data, with the aim of promoting privacy and confidentiality (Mason, 2018, pp.83-106; Savin-Baden \& Major, 2013, pp.319-337).

Each participant was assigned a code at the beginning of the interview to ensure the anonymity and data protection. During the transcription, the interviews had been anonymized and if necessary masked.

\subsection{Ensuring the Quality in the Research Process}

In the context of this study, research questions guided the process of development of interview guide. To ensure the quality of interview guide, especially checking if proposed guiding questions reflect the research questions of the study, the draft of the interview guide was discussed and commented in three $\mathrm{PhD}$ seminars held in Rwanda and Germany and was approved by the supervisor of this thesis. Comments and suggestions have been progressively integrated to improve the first draft of the interview guide until it was finalized. As the interview guide was translated from English to Kinyarwanda, one expert in English and Kinyarwanda crosschecked the translation. Furthermore, the interview guide was regularly adapted during interview process by checking if there were some unasked questions.

The interview process was always flexible and facilitates the process of progressively refining the interview guide for subsequent interviews. Concerning transcription, audio-recorded were carefully listened to in order to capture what the interviewee said. In order to provide highly accurate transcripts, I read and reviewed the text whereby each recording was listened to three times against the transcript. All transcripts were verified for accuracy by a professional editor. In addition, the proofreading of all transcripts was done by checking the transcript against the audio. 
During the data collection, a researcher assistant was recruited, and the training was organized for him. He was recruited based on his previous experience working with other researchers in the same study area. Even though he had experience in conducting research, the main researcher organized a training for him prior to the fieldwork covering explanation of research questions, the interview guides the research techniques to be used and the transcription procedures. The tasks that the research assistant undertook include conducting interviews with local community participants, aiding with the identification and invitation of participants, helping in taking notes of key issues while the main researcher is conducting interviews and participation in the transcription of interviews that could be verified and checked by the main researcher. The research assistant agreed to conduct research activities to the required academic and ethical standards. Since the research assistant is native and resides in one of the districts where the fieldwork took place, his work was essential to the process of familiarization with the studied context.

In the process of coding, the first three interviews were coded together with my $\mathrm{PhD}$ learning community in Rwanda and at University of Bamberg and verified in different PhD seminars. Moreover, in order to increase the visibility and validity of my study, the articles in this thesis have been discussed in higher education seminars, peer reviewed by different journal reviewers, and presented in international conferences(see appendix F, G, H, I, J). 


\section{Results}

This synopsis considers five papers. The papers are presented in an order that hopefully contributes to the larger picture of community' participation in conservation of natural resources management in Rwanda with the case of Nyungwe National Park. In this chapter, I first summarize the papers individually and give than a synthesis of my findings.

Stimulated by the GoR initiative to involve local communities in conservation of natural resources through TRS, I conducted a study on perceptions of local community participation in the process of conservation of Nyungwe National Park. Thus, paper one concerns the parks' governance and management in Rwanda: opportunity and challenges faced by the local community. Based on the experience from article one, it was necessary to take into consideration the voices of other stakeholders, especially women as important group in the community and in the conservation of natural resources to enrich my understanding of community participation. Thus, paper two concerns women' views on their empowerment and participation in the conservation of NNP. The first two papers provided insights into the interesting position that local communities occupied in the process of conservation of the Park. It was necessary to understand ecotourism as a potential conservation incentive and its impacts on community development around Nyungwe National Park in paper three. It was also necessary to investigate local community' perceptions on human-wildlife conflict and the compensation process. These results are published in paper four. The paper five describes nature of conservation policies and practices in Africa. An illustration of the papers, research questions and key findings is shown in the following table 12 and an extended overview of the five papers follows the table. 


\begin{tabular}{|c|c|c|}
\hline Papers & Research questions & Key findings \\
\hline $\begin{array}{l}\text { Paper 1: Parks' governance and } \\
\text { management in Rwanda: } \\
\text { opportunity and challenges faced } \\
\text { by the local community. }\end{array}$ & $\begin{array}{l}\text { - How do local communities } \\
\text { participate and perceive their role in } \\
\text { the conservation of the park? } \\
\text { - What are the benefits and }\end{array}$ & $\begin{array}{l}\text { - Local community participation } \\
\text { through keen activities based } \\
\text { cooperative associations and funded } \\
\text { projects, reference made to resources }\end{array}$ \\
\hline $\begin{array}{l}\text { Paper 2: Environmental Justice } \\
\text { and Women Empowerment in } \\
\text { Nyungwe National Park: Here the } \\
\text { focus is on women }\end{array}$ & $\begin{array}{l}\text { opportunities do they get as } \\
\text { neighbors of the Park? } \\
\text { - How do they participate in } \\
\text { decision-making process? } \\
\text { - What are challenges do they face } \\
\text { being neighbors of the park? } \\
\text { - What do local communities wish } \\
\text { to minimize the challenges they } \\
\text { face? }\end{array}$ & $\begin{array}{l}\text { use, awareness raising and skills for } \\
\text { interactions, cooperative spirit } \\
\text { promotion and entrepreneurship } \\
\text { through ecotourism and information } \\
\text { exchange. } \\
\text { - Ecotourism plays a crucial role } \\
\text { towards local community's } \\
\text { empowerment and biodiversity } \\
\text { conservation tools } \\
\text { - Partnership approach appear only in }\end{array}$ \\
\hline $\begin{array}{l}\text { Paper 3: Ecotourism as a potential } \\
\text { conservation incentive and its } \\
\text { impacts on community } \\
\text { development around Nyungwe } \\
\text { National Park }\end{array}$ & $\begin{array}{l}\text { - How does ecotourism empower } \\
\text { the local community living around } \\
\text { Nyungwe National Park? } \\
\text { - How do ecotourism promote the } \\
\text { conservation of the Park? }\end{array}$ & $\begin{array}{l}\text { some activities regarding the park } \\
\text { management such as joint patrol, } \\
\text { information exchange, consultation } \\
\text { - Passive participation (participation }\end{array}$ \\
\hline $\begin{array}{l}\text { Paper 4: Local community' } \\
\text { perceptions on human-wildlife } \\
\text { conflict and the compensation } \\
\text { process }\end{array}$ & $\begin{array}{l}\text { - How do people perceive human- } \\
\text { wildlife conflicts around Nyungwe } \\
\text { National Park? } \\
\text { - How do people perceive the } \\
\text { compensation scheme initiated to } \\
\text { minimize human-wildlife conflicts? }\end{array}$ & $\begin{array}{l}\text { during implementation and receiving } \\
\text { information) } \\
\text { - Lack of involvement in decision } \\
\text { making process, monitoring and } \\
\text { evaluation especially women (top- }\end{array}$ \\
\hline $\begin{array}{l}\text { Paper 5: Nature conservation } \\
\text { policies and practices in Africa : } \\
\text { Critical analysis, ideological } \\
\text { challenges and strategic vision for } \\
\text { protected areas sustainable } \\
\text { management }\end{array}$ & $\begin{array}{l}\text { - What are natural resources, } \\
\text { conservation policies and practices } \\
\text { in Africa? } \\
\text { - What are the gaps between } \\
\text { standards and field practices in } \\
\text { natural resources conservation in } \\
\text { Africa? } \\
\text { - What are alternative strategies for } \\
\text { sustainable management of natural } \\
\text { resources in Africa? }\end{array}$ & $\begin{array}{l}\text { down approach) } \\
\text { - Crop-raiding as a challenge faced } \\
\text { by local community } \\
\text { - Complicated compensation process } \\
\text { - Claim of active participation } \\
\text { - Claim of continuous incentives and } \\
\text { education programs }\end{array}$ \\
\hline
\end{tabular}

Table 12: Illustration of the papers, research questions and key findings 


\section{Paper 1: Parks' Governance and Management in Rwanda: Opportunities and Challenges of the Community Participation for a Sustainable Conservation}

In paper 1, I assessed how the local community understands their role and participation in the conservation of NNP. I assessed how they benefit and what kinds of opportunities they get as neighbors of the park as well as the challenges they face.

The study adopted a qualitative approach based on semi-structured individual interviews to key stakeholders from different categories of stakeholders including local communities. The data collected were transcribed, translated, and analyzed using content analysis methods, MAXQDA Software and a coding system.

The results show that the involvement and empowerment of local people are done through keen activities based cooperative associations and funded projects, references are made to resources use, awareness raising and skills for interactions, cooperative spirit promotion and entrepreneurship as well as information exchange. The findings indicate that the level of communities' participation remains passive and is still low though community members benefit of jobs, loans for their projects and income generating activities such as organized productions for market thanks to tourism revenue sharing and revolving fund programs. Though, local communities gradually understand the role of the park thanks to income generating activities and community projects, the new approach does not meet basic criteria for effective community participation (refer to Reed, 2008; Tosun,1999, 2000; Pretty, 1995) to ensure the sustainability of the conservation. However, the socio-economic incentives have a positive impact on the reduction of illegal activities.

\section{Paper 2: Environmental Justice and Women Empowerment}

In Paper 2, I assessed women's experiences about their empowerment, in terms of distributive and procedural justice and challenges they face as women.

The study adopted a qualitative approach based on semi-structured individual interviews to women. The data collected were transcribed, translated, and analyzed using content analysis methods.

The findings show that women are socially and economically empowered. In terms of economic empowerment, access to financial loans, savings, employment, and income generating projects are the major indicators of the empowerment. Improved capacity building and family relations are major concerns of social improvement among women. 
However, regarding the participation of women in decision-making process, it is still limited because of the dominance of top-down approach that does not consider enough women's voices and suggestions in decision making. Women perceive and consider the process of communication and decision-making as passive because they are almost absent in the monitoring and evaluation processes. The participation of the community members including women only appears through meetings with or without elected representatives (refer to Pretty, 1995). The process of women empowerment is still limited by some challenges such as crop raiding, complicated and slow compensation process, high interest rate and slow process of loan and inadequate communication. The partnership approach is then recommended to consider women's needs and voices in the implementation of natural resources conservation policies (refer to Reddy, 2002).

\section{Paper 3: Ecotourism and its Impact on Community Development around Nyungwe National Park (NNP)}

In paper 3, we assessed the potential of tourism revenue sharing in empowering local community and its role to act as an incentive to conserve biological diversity using Nyungwe National Park (NNP) and its neighboring communities, we assessed how local community benefit from tourism revenue sharing, how they are involved in tourism development and conservation activities around Nyungwe National Park. We assessed whether tourism revenue sharing can act as an incentive for conservation of the park.

The study used a mixed approach with structured questionnaire to collect data from local residents, while few face-to face interviews were conducted with key informants from Rwanda Development Board as means to obtain deeper insights.

$47.5 \%$ of respondents agree to have got job in tourism sector and other related domains. $30.8 \%$ of respondents agree the fact that tourism revenue sharing improved and developed infrastructures such as schools, roads, health centers and water tanks. However, the findings indicate that there is little involvement of local communities in decision making regarding NNP management. The interpretation of the data made visible that in the light of the research results, the decision-making system for Nyungwe National Park tourism and conservation development plans is a top-down approach and the participation of the local community is passive. 
Most of the respondents $95 \%$ indicate that there is a lack of local community involvement in decision making. There are still illegal activities from the local community such as tree cutting, burning forest, and hunting wild animals because people around NNP rely on woods, medicines, and honey from the park. According to RDB, "crop raiding constitutes a big challenge to the Park neighboring community". Almost all respondents indicate that tourism revenue sharing, and related benefits could serve as an incentive for conserving NNP and conclude that if tourism is well managed, it can act as an incentive for conservation through stopping illegal activities and promote the well-being of the local community. The study recommends that local communities around Nyungwe National Park should be consulted and actively involved in development programs.

\section{Paper 4: Community Perceptions of Human-wildlife Conflicts and the Compensation \\ Scheme}

In paper 4, I assessed how the local community perceives human-wildlife conflicts and how they perceive the compensation scheme that was set up to minimize the conflicts. A qualitative method was adopted. It relied on field semi-structured interviews with the representatives of conservation key stakeholders including local communities that experienced crop raiding.

The findings indicate that the local community is affected by crop raiding and complain about socio-economic and livelihood losses, food insecurity, loss of time for crop guarding, health degradation and the use of children in crop guarding. The findings indicate that the local

community is not satisfied with the compensation scheme due to the difficult requirements for compensation, complicated compensation procedure, rejection of compensation claims, undervalued payment and irregular compensation and delay of payments. The findings indicate that the compensation process is so slow, so long and so costly that the victims of crop raiding abandon compensation claims. The findings call for an improved compensation scheme for reduced human-wildlife conflicts and efficient management. Even though fencing the park could be expensive, it was proposed as a viable option to minimize wild animals escape from the park. In addition, enhancing collective guiding system is proposed by the local community to reduce crop raiding. 


\section{Paper 5: Nature of conservation policies and practices in Africa}

In paper 5, we explored and synthesized conservation policies and practices, we identified and analyzed gaps between standards and field practices and propose alternative strategies for sustainable management. The methodology adopted in this study relies on the interpretative and analytic synthesis of available literature on nature conservation.

The results show that the conservation policies and practices have generated devastating social conflicts and continuous degradation of most of protected areas because of many factors including the lack of management goals, categories, and plans. Due to a painful past and an inconsistent present, the management rules have globally failed to maintain original situations at least. The study shows that the poor performances of protected areas management are explained by recurrent conflicts of ideologies, interests, and agendas between conservation stakeholders. The vision developed to address the ideological and management challenges relies on a deep reorientation of normative classifications, strategic partnerships and administration, financing and compensation mechanisms and ecotourism development.

The figure 6 was developed from the findings from the papers. The figure shows the interconnectedness of the findings from the different articles to show their interconnectedness, and to give a holistic understanding of the complexity of community participation in national parks.

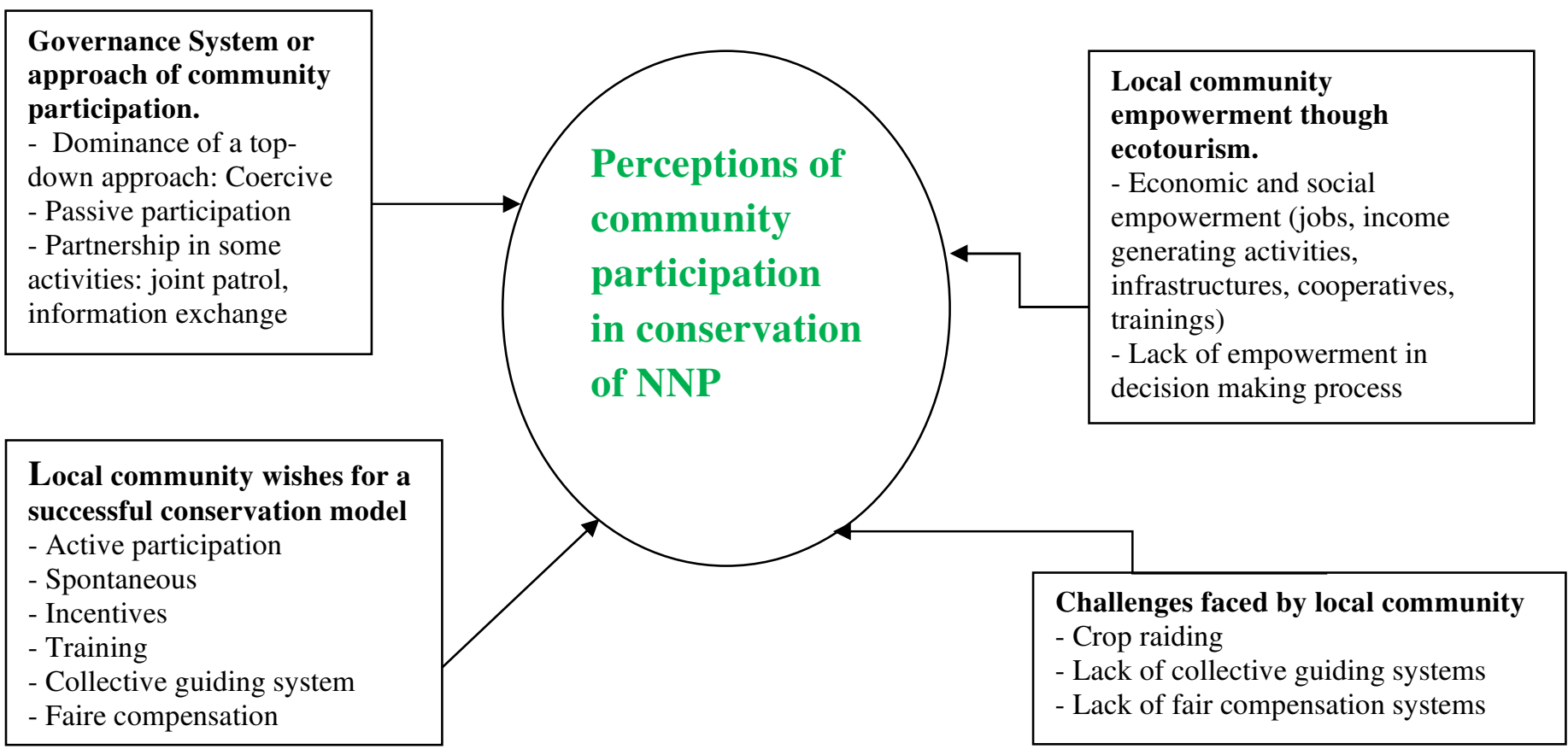

Figure 6: Link between findings 
The figure 6 summarizes local community perceptions with regards to the types or approaches of community participation (paper 1,2), perceptions about how people are empowered (paper 1, 2, 3 ), the challenges local community faces as neighbors of the park (paper 4) and their wishes for sustainable conservation of the park (all papers). The overall category for these categories is community participation in conservation of natural resources.

The governance or approaches of community participation are shown at the top left, the people' views on community empowerment as one aspect of community participation at the top right, the local community' perception on the challenges they face as neighbors of the park at the bottom right and finally strategies or wishes to handle the mentioned challenges that hinder a successful participation at the bottom left.

Participatory management that seeks to reintegrate local populations into the management of protected areas was initiated through a decentralized governance approach as a strategy to achieve conservation goals and meet local communities' expectations. The model above shows that in the process of conservation of NNP, the government still plays a central role as it concentrates the ownership and the responsibility for the management of protected. The integrated of conservation and development projects relies mainly on ecotourism development projects such as the construction of schools and health structures, income generating activities like the sale of some handcraft products and low-paid jobs by local staff such as tour guides, tourist baggage handlers and maids in hotels. Local communities' participation is passive and their participation has simply become a way of validating decisions already made by park managers where decentralized and democratic management approaches are dominated by centralized and coercive practices which may raises the problem of relevance of participation, transparency in management, equity in benefit sharing and environmental justice.

The persistent of human wildlife conflicts such as crop-raiding and the lack of fair and equitable compensation for damages, lack of collective guarding system are factors that do not promote positive tourism development and become serious challenges in achieving effective community participation in the conservation of the park. 
To be more effective, the governance system should be spontaneous and empower local people through education program for them to be able to influence political decisions. The increase of incentives for fair compensation and collective guarding systems should be adopted in order to minimize human-wildlife conflicts. 


\section{Summary and Discussion}

\subsection{Summary of the findings}

The present study had the purpose of investigating how local community participates in conservation of Nyungwe National Park and how they are empowered in the context of protected areas of the Nyungwe National Park. The findings as previously presented are discussed in relation to existing scientific discourse on effective community participation, distributive and procedural justice to community empowerment in the context of conservation of natural resources in Rwanda. Most of respondents interviewed perceived the national park as a benefit to them and have positive attitudes towards its conservation. The benefits to communities and households include classrooms, health clinics (health point), clean water, income generating activities (employment in park and tourism related activities, livestock), clean air, local climate regulation, conservation education and training, as well as funding opportunities.

Firstly, the results of the study show that local communities who live adjacent to Nyungwe National Park are gathered into cooperatives and they are socially and economically empowered. They are grouped in different cooperatives based on what they used to do inside the forest when it was not yet conserved. They are empowered economically through capacity building, access to loan, employment, had opportunities to improve their household status. Among others, they started income generating activities; improve family relations which lead to support RDB in the process of sensitization and mobilization of the local population about the role of the park and its conservation. Moreover, this sort of empowerment led to the satisfaction of cooperative members with regards to employment, health insurance, food security and environmental raising awareness. The mobilization and organization of the population under RDB and conservation NGO's empowerment achieved a number of goals such as: (1) community joint patrols for conservation; (2) organization of cooperatives and associations for mutual empowerment and collective responsibility; (3) revenue injection in local development and improved well-being; and (4) conservation awareness (refer to figure 6 and table 12). In concrete terms, the community members participate in wildfire fighting, identifying their own needs; in joint patrol program, removing traps in the park, information exchange and working with researches and carrying tourist's luggage. Local community empowerment has touched many groups including youth and women. 
Secondly, community participation in decision-making, despite recognition of economic empowerment, is very limited. Results show that local communities in the cooperatives are only informed about decisions without their input. The decision-making process is still dominated by a top-down approach where local community participation is passive. Local communities are only informed about what is going to happen and it is done through representatives or in meetings.

Thirdly, the findings indicated that a top down approach, crop raiding and complicated compensation process are key challenges for the sustainability of conservation of Nyungwe National Park. The above challenges do not promote positive tourism development and handicap the achievement of conservation goals as well as local communities' expectations. These challenges are directly or indirectly related to the implementation of decentralization policies whereby the voices of local communities are to be recognized. Additionally, the challenges might be reflected in relation to management approach used especially in involving local communities in natural resources management in the protected areas.

\subsection{Beyond People and Park Relations}

In the following sub-chapter, I am going to discuss beyond people and park relation and reflect about participation as an educative function (5.2.1), ecotourism as an empowerment tool (5.2.2) and participation as an integrative function into society (5.2.3).

\subsubsection{Participation as educative function}

In Paper 1 and 2, the findings indicate that cooperatives were promoted to strengthen the bonding within the local community. This allows group members to overcome collective challenges and promote cooperation toward common goal. Within community's associations, people learn to work together, share information knowledge, experiences, and resources. This step is a key to the success of sustainable conservation and preservation through community participation.

This relates to findings about the relation between local community participation and personal growth. This means that increasing participation in outdoor settings, when associated with adequate interpretation programs, can change behaviors and secure greater support for natural resource conservation (Rattan et al., 2012). Community participation approach has the potential to make major contribution in educating people and enriching their quality of life. 
This helps to mobilize and empower people with the knowledge and skills to participate more actively, more democratically, and more collectively in the development process. In addition, participation in natural resources conservation can strengthen community stewardship, unions and the team working spirit.

Henceforth, information exchange and good communication upward and downward is a key. Persistent exchange of information and communication lead community members to contribute to the formulation of management plans, openness to capacity building, self-confidence for entrepreneurship and project initiation and management other than illicit exploitation of the parks. They assist in firefighting; they contribute to project evaluation and biodiversity monitoring. This is similar to what Reed, (2008) noted.

The collaboration between park's staff, local community and the medias is a good strategy that promotes talks and exchange of different matters with regards to the life of the local community and the protection of the park. Gradually, the community understands the role of the park compared to the past when they valued the forest in terms of mining activities, timber, and poaching. Today, the attitude and behavior have changed; they know the role the parks play in generating income for community projects. This collaboration between the park and the community is the one way to achieve the sustainability in terms of promoting the well-being of the community and park protection. However, community participation is more effective when people are given specific tasks and trainings (refer to paper 1,2, and 3).

Therefore, my findings may add to the general discourse on the community involvement in conservation of national parks, that participative processes are not only leading to greater sustainability and protection of the parks but as well to the development, personal growth and education of the population. This contribution of participatory processes in society may not be underestimated. 


\subsubsection{Ecotourism as Empowerment Tool}

Scholars indicate that conservation of natural resources in the protected areas is quite impossible if surrounding people live in poverty (Fennell, 2015; Kipkeu et al., 2014; Masozera, 2002; Plumptre, 2004; Scherl, 2004). In addition, local people's willingness to participate in biodiversity conservation and landscape protection depends, to some extent, on whether their basic needs are satisfied since they rely on natural resources for their survival (Fennell, 2015). There are several ways to understand and describe the impact of ecotourism on local communities.

Here, I describe the contribution of ecotourism to (1) the empowerment of local people, (2) the direct economic impacts on the local community.

I assessed in paper 1, 2, 3 whether the tourism revenue sharing in Rwanda has had an effect on local community living experiences and I was able to show these effects. I focused on how local community is empowered to participate in conservation practices and conservation decisions and the findings in Paper 1, 2, 3 answer the research questions about how local people benefit from ecotourism, their role in conservation practices and decisions.

Since 2005 the Government of Rwanda initiated a policy about tourism revenue sharing where the money from tourism activities is shared at $10 \%$ with the local community to support their projects and support local infrastructure development such as schools, health centers, water systems, raising awareness, and local community trainings (RDB, 2017). The findings are similar to what other scholars indicate on how ecotourism empowers local people, improve resources stewardship and contribute to the reduction of human activities that threaten the Park (Baromey, 2008; Ferraro \& Hanauer, 2015; Manu \& Kuuder, 2012; Mohd \& Sheikh, 2009). This program was introduced under the premise that local people needed greater interest in the sustainable use of natural resources, has greater knowledge about the local ecological processes, and needed to participate more effectively in the management of local resources.

In the track of local community empowerment women as an important group, should not be left behind. Scholars argue that women are influential in the process of change (Ferguson \& Alarcon, 2015; OECD, 2014,) and engaging sustainable development initiatives without involving them is an empty gesture (Dobson, 1998). Therefore, empowering women in protected areas of Nyungwe National park is likely to achieve better conservation outcomes. 
Furthermore, findings corroborated (Braidotti et al. 1994) the point of view whereby increasing women participation and empowering, lead to better conservation outcomes as they have privileged knowledge and experience of working closely with the environment. However, ecotourism may create conditions for the persistence of unequal powers, where small and external groups of stakeholders might marginalize local communities (Mathis \& Rose, 2016). Thus, ecotourism to be successful it should accommodates local community involvement to have the relevant assets and instrumental freedoms (representation and consultation) to achieve different functioning including human assets (health and education); natural assets (having access to resources); and physical assets by accessing to infrastructure as Schlosberg, (2007) noted.

\subsubsection{Participation as integrative function}

Local community participation contributes to people's feeling that they belong to their community. However, in this study, based on the model of community participation as developed by Pretty (1995) and Tosun (1999), it can be revealed that community participation in decision-making process is passive and coercive. With passive participation, relationship between community members and decision makers is quite asymmetric. Members of the community play the only role of receiving or giving information which might be or not relevant to their needs. Moreover, the findings are in line with the top-down approach whose assumptions are to consider communities as passive in the process of decision-making (Paudel, 2009; Pretty, 1995; Reed, 2008; Reddy, 2002, Tosun, 1999).

Though the findings of this study show promising socio- economic benefits for local community, the sustainability of the change regarding their development and natural resources conservation is questionable if they do not own the initiatives undertaken by decision-makers. This is because the sustainability is a result of close collaboration between stakeholders i.e. government and the community in planning and making decisions for sustainable conservation and benefit sharing for development process (Reed 2008; Reddy, 2002).

On one hand some of the ideas from local community's cooperatives are not considered by decisions makers because they are the one who thinks and decides what is to be done. With this local community in the cooperative consider being part in decision making process by receiving reports and information from decision makers, this show that there is a passive participation where local community participate only when receiving information from decision makers. 
This finding is in line with Pretty (1995) and Tosun (1999) models of community participation that shows passive participation where communities participate in receiving information (refer to paper $1,2,3)$.

On the other hand, findings revealed that a little partnership and bottom-up approaches are used where the local leaders and the community meet for deciding on different activities like payment for the damaged crops and punishment for people who violate law governing the park. This finding is in line with the idea of Paudel (2009) and Reddy (2002) who said that the government and the community work together in planning and making some decisions for better and sustainable conservation and benefit sharing for development process.

Participatory processes in decision making is a tool that promote trust between local community and decision makers (Hoverman et al., 2011, Paudel, 2009; Pretty, 1995; Reddy, 2002,) and reach to better conservation outcomes as well as promote the success of rural development goals (Belshaw \& Chambers, 1973; Uphoff et al., 1979), when there is an emphasis on the importance of local capacity building, knowledge ownership, and empowerment (Chambers, 1994). With this regard, a partnership approach (Reddy, 2002) needs to be reinforced as a tool to sustainable conservation outcomes. According to Morshed (2013) co-management of protected areas is a participatory approach to natural resource conservation that can also lead to improvements in local livelihoods. This is supported by the idea that participation plays an important role in producing and implementing laws and rules that are acceptable to all and makes citizens better able to make decisions and understand them.

\subsection{Concluding remarks}

The study shows that the recent policy of community participation in the management of NNP has brought new perspectives and hope for sustainable conservation. Many conservation NGOs have moved to work along the populations to empower them and accompany initiatives, entrepreneurship and projects that overturn they are eternally depending on the natural resources of NNP. The new philosophy of socio-economic development for the communities based on

grouping them in cooperative associations and empowering them has created a good relationship between them and the Park's management. 
The study shows that environmental distributive justice leads to social and economic empowerment of local community living in the protected areas of Nyungwe National Park.

However, the findings indicate that the top down management model is not significantly beyond the horizons where RDB is orchestrating much of the processes including the definition of the policies, the monitoring and evaluation of the revenue of tourism and the organization, the planning and the supervision of the management meetings. Despite the increasing importance of the tourism revenue shared to the local communities, community members still believe that most of the projects presented and funded by the revenue are state and district oriented to achieving imihigo or District performance contracts, instead of community direct empowerment and well-being improvement. This study recommends that, local community should be empowered through education, raising awareness through community mobilization, and creating jobs so that they can increase knowledge and capabilities to influence decisions.

There should be a flow of information exchange from decision makers to stakeholders about projects that are to be developed. Local communities should be given the ground to identify their needs so that they are helped to formulate projects. Much education is needed to link the projects with the well-being and transformation of the life of local populations. Equally, an effort is needed for the local communities to be fully involved in the processes of project definitions and elaboration, project monitoring and implementation and park management meetings.

RDB should develop a clear and real community-based conservation approach that will see communities around NNP region actively participate in the decision-making process of activities related to tourism and conservation. Using the theoretical criteria for effective community participation, RDB should promote an interactive participation approach where people, including local communities, local governments and RDB itself will collaborate and participate together in the development of action plans and structure or strengthening of local institutions. Adding to that, RDB should develop mechanisms that empower local communities in increasing skills otherwise some of the local communities will only participate passively (refer to paper1, 2, 3).

Based on research findings, the partnership approach should be emphasized in empowering the communities especially women, youth, and other groups by hearing their voices and build trust 
among the entire community members. Regular meetings and consultation must be increased as one way of gathering more information on time and encourage positive endeavors to protect and safeguard Nyungwe National Park. Moreover, sensitization must be used as a continuous tool to change the mindset of resisting people and to show them different alternatives to the park destruction. Regarding human-wildlife conflict, this study recommends a development of a collective guarding system and the ease of the compensation process. 


\section{Implications of the study}

The findings from this study helped me to develop an understanding of how people perceive the role and participation of the local community in natural resources management with the case of Nyungwe National Park.

One of the strengths of this study is the multi-stakeholder design. The study took into consideration the voices of various conservation stakeholders (local community, NGOs, and park staff), and this indicated the image of the local community and park relationship. Community conservation is an issue of concern and interest to various stakeholders but is a complex issue, especially given that different stakeholders hold different views. The multi-stakeholder analysis generated extensive empirical data that lead to extensive analysis with a complexity of views from different groups. The study gives different implications for the practice of community involvement.

\subsection{Implications of the study for the policy makers, NGOs, and local communities}

In order to develop and maintain biodiversity conservation in a society, the theoretical overview emphasizes a strong collaboration and partnership among local communities, government, private sector, and civil society organizations. If local communities do not participate effectively in conservation matters and teach their children, the latter, in turn, will not be able to consider natural resources as their own responsibility.

Community conservation theories stress much the role of the local community and clearly show why they stand the best chance when it comes to conservation of natural resources. However, the major findings in this study indicate that there is little involvement of the local communities in resources management and decision making in NNP.

Though, there is a passive participation, the local communities expressed their eagerness to acquire some more skills and knowledge to help planners on the road to achieve conservation goals and meet their expectations. 
Hence, there is a need of establishing local community's programs to this end. Local communities should be engaged and should be involved in development programs in their villages right from the start. Equally an effort is needed for the local communities to be fully involved in the processes, project definitions and elaboration, project monitoring and evaluation.

RDB should develop a clear community-based conservation approach that will see communities around Nyungwe National Park region actively participate in the decision-making process of activities that are related to tourism and conservation in the area. Moreover, attention needs to be given to improving conservation skills among the local communities in order to produce independent, critical, and lifelong conservationists.

Tourism activities in Nyungwe National Park should be appropriately planned, monitored, and managed to ensure that they do not conflict with conservation and sustainable use of resources, as well as compromise the livelihood of local residents. For this end, much effort is needed to link projects with the well-being and transformation of the life of the population.

The study clearly shows that the existing link and collaboration between local communities, International and Government NGOs should be strengthened to promote, foster, and enhance the much-needed conservation outreach strategy where conservation practices and innovations can be nurtured and developed. Consequently, there is need to re-evaluate and emphasize on the following: Local community participation, community empowerment, linking benefit to conservation.

To conclude, as earlier said, local community participation is understood in terms of how people actively and creatively apply conservation skills to suit their own purposes and needs including knowledge, benefits and problem solving. Therefore, mechanisms which empowers them to become actively engaged in identifying their problems, asking questions, analyzing, and developing strategies for transformation should be put in place. 
The ideal approach, if people want to develop a conservation habit, is that they plan, implement, and decide together. This requires a strong commitment and trust both from decision makers and stakeholders to avoid conflicts of interests. This approach may not be easy but once it is achieved it may turn later into a culture.

\subsection{Limitation of the study}

The limitation of the study is that it did not consider many decision makers as respondents rather the focus was more on the local community. The sample size of some of the groups, such as park's staff and participants from NGOs, can be criticized as small. This is the reason why measures were taken to carefully select participants to promote the quality of the findings. A mixed sample of participants was emphasized to maximize variation (local community, women, Park's staff, NGOS).

In addition, key persons from the selected organizations/institutions were a priority for the interviews. Such selection helped to provide a variety of understandings and fuller understanding of the role of the local community in conservation of the park, how they are empowered and kinds of the challenges they face. Therefore, with that selection of diverse persons or cases, one can expect to have sufficient variation and generalization (Larsson, 2009).

\subsection{Implications for further research}

Enhancing local communities' participation can contribute to their positive transformation especially in developing countries. Given today's rapid progress registered in all walks of life in Rwanda, various government policy and planning documents put forward decentralization policy as the base for sustainable socio-political and economic development resulting in poverty reduction, development, and good governance. Community participation in natural resources management and conservation seems to offer adequate means to cope with this change. Enhancing community participation strategy will contribute to transform the Rwandan citizen into skilled human capital for socio-economic development of the country. 
The study gives hints and suggestions for further research. The next step for research should be the assessment of how decision makers of both, government, and non-government organization, define and perceive effective community participation, and understand their cooperation in promoting the well-being of the local community around protected areas. The above question is important because it shows the views of those who develop policy, plan, coordinate activities, and make decisions about the management and development of the park. To ensure that the management of the park and other protected areas is sustainable, government on national, regional, and local levels needs to define and understand well the role of the local community. Moreover, this question is of interest in developing responsible citizens in modern society in terms of their capacity building. Decision makers are expected to empower local community to become responsible for their continuous transformation or development and to remain productive in society. They also play a pivotal role in helping local communities to develop and maintain a positive attitude towards conservation. In addition, the understanding of decision makers' perceptions regarding park development and management is highly essential in order to understand the significance and value of local community participation. This understanding can help planners in formulating policies and be able to select projects that can minimize negative threats to the park.

Future research would continue to investigate and shed light upon issues of developing effective community conservation approach in the three other national parks in Rwanda and the bordering national parks in Burundi, Tanzania and the Democratic Republic of Congo in order to develop with the findings a regional strategy. In fact, the five partner States of the East African Community (EAC) namely Kenya, Rwanda, Burundi, Uganda, and Tanzania share terrestrial and aquatic ecosystems. These ecosystems are primary assets and a store of wealth - wildlife, flora, and fauna, which if well managed, could contribute to poverty alleviation in the region. In a nutshell, I believe that kinds of research can be of interesting in a broader context especially in the EAC and hopefully that will contribute to the regional change of the mindset towards the role of local communities in conservation of natural resources as well as the harmonization of existing practices and policies. 


\section{References}

Adams, M.W. \& Infield, M. (2003). Who is on the Gorilla's Payroll? Claims on tourist revenue from a Ugandan National Park. World Development, 31(1), 177-190.

Adams, W. M., Aveling, R., Brockington, D., Dickson, B., Elliott, J., Hutton, J., \& Wolmer, W. (2004). Biodiversity conservation and the eradication of poverty. science, 306(5699), 11461149 .

Adams, W. M., \& Hulme, D. (2001). If community conservation is the answer in Africa, what is the question? Oryx, 35(3), 193-200.

Adams, W.M. \& Hutton, J. (2007). People, parks and poverty: political ecology and biodiversity conservation. Conservation and Society, 5 (2), 147-183.

Agrawal, A. \& Ribot, J. (1999). Accountability in decentralization: A framework with South Asian and West African cases. The Journal of Developing Areas, 33, 473-502.

Allendorf, T., Swe, K. K., Oo, T., Htut, Y., Aung, M., Allendorf, K., ...\& Wemmer, C. (2006). Community attitudes toward three protected areas in Upper Myanmar (Burma). Environmental Conservation, 33(4), 344-352.

Alexander, S. M., Andrachuk, M., \& Armitage, D. (2016). Navigating governance networks for community-based conservation. Frontiers in Ecology and the Environment, 14(3), 155-164.

Andrade, G. S., \& Rhodes, J. R. (2012). Protected areas and local communities: An inevitable partnership toward successful conservation strategies? In: Ecology and Society, 17(4), 1429.

Anthony, B. (2007). The dual nature of parks: Attitudes of neighboring communities towards Kruger National Park, South Africa. Environmental Conservation, 34(3), 236-245.

Archabald, K. \& Naughton-Treves, L. (2001). Tourism revenue-sharing around national parks in Western Uganda: Early efforts to identify and reward local communities. Environmental Conservation, 28 (2), 135-149

Ary, D., Jacobs, L. C., Razavieh, A., \& Chris Sorensen, C. (2013). Introduction to research in education: Cengage Learning. Journal of Correctional Education, 9-22.

Ashley, C. \& Garland, E. (1994). Promoting community-based development: Why, what and how? Research discussion paper No. 4. Ministry of Environment and Tourism. Windhoek, Namibia. 
Baerlein, T., Kasymov, U., \& Zikos, D. (2015). Self-governance and sustainable common pool resource management in Kyrgyzstan. Sustainability, 7(1), 496-521.

Bailey, J. (2008). First steps in qualitative data analysis: transcribing. Family practice, 25(2), $127-$ 131.

Ban, N. C., Epstein, G., Ban, N. C., \& Epstein G. (2014). Governing large-scale social-ecological systems: Lessons from five cases. International Journal of the Commons, 8, 428-456.

Baral, N. (2012). Empirical analysis of factors explaining local governing bodies' trust in administering agencies in community-based conservation. Journal of Environmental Management, 103, 41-50.

Baromey, N. (2008). Ecotourism as a tool for sustainable rural community development and natural resources management in the Tonle sap biosphere reserve. Kassel University Press, Kassel

Bennett, N. J. (2016). Using perceptions as evidence to improve conservation and environmental management. Conservation Biology, 30, 582-592

Berkes, F. (1986). Local-level management and the commons problem: A comparative study of Turkish coastal fisheries. Marine policy, Vol. 10(3), 215-229.

Berkes, F. (2004). Rethinking Community-Based Conservation. Society for Conservation Biology Vol. 18(3), 621-630.

Berkes, F. (2006). The problematic of community-based conservation in a multi-level world. In Biennial meeting of the International Association for the Study of Commons (IASC). Bali, Indonesia.

Berkes, F. (2010). Devolution of environment and resources governance: trends and future. Environmental Conservation, 37, 489-500.

Blaikie, N. (2007). Approaches to social enquiry. Advancing knowledge. Cambridge: Polity Press

Blanco, E. M. \& Razzaque, J. (2011). Globalisation and natural resources law: challenges, key issues and perspectives. Edward Elgar Publishing Limited, Cheltenham

Blomley, T., Namara, A., McNeilage, A., Franks, P., Rainer, H., Donaldson, A., Malpas, R., Olupot, W., Baker, J., Sandbrook, C., Bitariho, R. and Infield, M. (2010). Development and gorillas? Assessing fifteen years of integrated conservation and development in south-western Uganda, Natural Resource Issues No. 23. London: IIED. 
Borrini, G., Dudley, N., Jaeger, T., Lassen, B., Neema, P., Phillips, A., \& Sandwith, T. (2013). Governance of protected areas: from understanding to action. Best practice protected area guidelines series, (20), Gland, Switzerland: IUCN.

Braidotti, R., Charkiewicz, E., Hausler, S., \& Wieringa, S. (1994). Women, the environment and sustainable development (p. 94). London: Zed Books.

Brashear, T. G., Brooks, C. M., \& Boles, J. S. (2004). Distributive and procedural justice in a sales force context: Scale development and validation. Journal of Business Research, 57(1), 8693.

Braun, V., \& Clarke, V. (2013). Successful qualitative research: A practical guide for beginners. London: Sage.

Briedenhann, J., \& Wickens, E. (2004). Tourism routes as a tool for the economic development of rural areas - vibrant hope or impossible dream? Tourism management, 25(1), 71-79.

Brockington, D. (2002). Fortress conservation: the preservation of the Mkomazi Game Reserve, Tanzania. Oxford: James Currey.

Bryman, A. (2008). Social research methods ( $3^{\text {rd }}$ ed). Oxford: Oxford University Press

Bryman, A. (2012). Social research methods $\left(4^{\text {th }}\right.$ ed). Oxford: Oxford University Press

Bulte, E. H., \& Rondeau, D. (2005). Why compensating wildlife damages may be bad for conservation. The Journal of Wildlife Management, 69(1), 14-19.

Bush, G. K., Ikirezi, M., Daconto, G., Gray, M., \& Fawcett, K. (2010). Assessing impacts from community conservation interventions around Parc National des Volcans, Rwanda. Dian Fossey Gorilla Fund International, Rwanda.

Cantiani, M. G., Geitner, C., Haida, C., Maino, F., Tattoni, C., Vettorato, D., \& Ciolli, M. (2016). Balancing economic development and environmental conservation for a new governance of Alpine areas. Sustainability, 8(8), 802.

Cetas, E.R. \& Yasué, M. (2017). A systematic review of motivational values and conservation success in and around protected areas. Conservation Biology, 31, 203-212.

Chambers, R. (1994). Participatory rural appraisal (PRA): Analysis of experience. World development, 22(9), 1253-1268.

Charmaz, K. (2014). Constructing grounded theory ( $2^{\text {nd }}$ ed). Thousand Oaks: Sage.

Chemouni, B. (2014). 'Explaining the design of the Rwandan decentralization: Elite vulnerability and the territorial repartition of power'. Journal of Eastern African Studies, 8(2), 246-262. 
Chirozva, C. (2015). Community agency and entrepreneurship in ecotourism planning and development in the Great Limpopo Transfrontier Conservation Area. Journal of Ecotourism, 14(2-3), 185-203.

Chok, S. \& Macbeth, J. (2007). Tourism as a tool for poverty alleviation: a critical analysis of 'propoor tourism' and implications for sustainability. Current Issues in Tourism, 10, 144-164.

Claiborne, P. (2010). Community Participation in Tourism Development and the Value of Social Capital - the case of Bastimentos, Bocas del Toro, Panamá. University of Gothenburg, school of business, economics and law

Cobbinah, P. B. (2015). Contextualizing the meaning of ecotourism. Tourism Management Perspectives, 16, 179-189.

Colchester, M. (2003). Nature sauvage, nature sauvée? Peuples autochtones, aires protégées et conservation de la biodiversité. Mouvement mondial pour les forêts tropicales, Forest Peoples Programme.

Cole, S. (2006). Information and empowerment: The keys to achieving sustainable tourism. Journal of sustainable tourism, 14(6), 629-644.

Corbin, J., \& Strauss, A. (2008). Basics of qualitative research. London: Sage.

Crawford, A. (2012). Conflict-Sensitive Conservation in Nyungwe National Park: Conflict Analysis Report. International Institute for Sustainable Development.

Creswell, J.W., Plano-Clark, V.L., Gutmann, M.L., \& Hanson, W.E. (2003). Advanced mixed methods research designs. In Tashakkori, A. \& Teddlie, C. (Eds., pp. 209-240) Handbook of mixed methods in social and behavioral research. Thousand Oaks, California: Sage.

Creswell, J. W., \& Plano Clark, V. L. (2007). Designing and conducting mixed method research. California, USA: Sage

Creswell, J.W. (2013). Research design: Qualitative, quantitative, and mixed methods approaches (4th ed.). Thousand Oaks, California, USA: Sage.

Davidson, C., \& Tolich, M. (2003). Competing traditions. Social science research in New Zealand: Many paths to understanding, 2, 23-38.

Dearden, P., Bennett, M. \& Johnston, J. (2005). Trends in global protected area governance, 1992 -2002. Environmental Management, 36, 89-100.

Dickman, A. J. (2010). Complexities of conflict: the importance of considering social factors for effectively resolving human-wildlife conflict. Animal conservation, 13(5), 458-466. 
Dixey, L. (2008). The unsustainability of community tourism donor projects: Lessons from Zambia. Responsible tourism: Critical issues for conservation and development, 323-341.

Dobson, A. (1998). Justice and the environment: Conceptions of environmental sustainability and theories of distributive justice, Oxford: Clarendon Press.

Doolittle, A. A. (2007). Fortress conservation. Encyclopedia of environment and society, 1, 704705.

Eckerberg, K., Bjärstig, T., \& Zachrisson, A. (2015). Incentives for collaborative governance: Topdown and bottom-up initiatives in the Swedish mountain region. Mountain Research and Development, 35(3), 289-298.

Eckerberg, K., Bjärstig, T., Miljand, M., \& Mancheva, I. (2020). Devolving power from the state: local initiatives for nature protection and recreation in Sweden. Local Environment, 1-14.

Estrella, M. \& Gaventa, J., (1998). Who counts reality? Participatory Monitoring and Evaluation: a literature review. IDS Working Paper 70, Institute of Development Studies, Brighton.

FAO (2005). Negotiation and mediation techniques for natural resource management by Antonia Engel and Benedikt Korf. Rome.

Fennell, D. A. (2015). Ecotourism, 4th ed. London: Routledge

Ferguson, L., \& Alarcon, D. M. (2015). Gender and sustainable tourism: reflections on theory and practice. Journal of Sustainable Tourism, 23(3), 401-416.

Ferraro, P. J. \& Hanauer M.M. (2015). Through what mechanisms do protected areas affect environmental and social outcomes? Philosophical Transactions of the Royal Society B: Biological Sciences 370.

Flick, U. (ed.). (2013). The SAGE handbook of qualitative data analysis. London: Sage.

Fraser, N. (2008). Scales of Justice: Reimagining Political Space in a Globalizing World, New directions in critical theory. Cambridge: Polity Press.

Fraser, N. (2010). Scales of justice: Reimagining political space in a globalizing world. Columbia: University Press.

Fraser, N. (2010). Injustice at Intersecting Scales: On "Social Exclusion" and the "Global Poor". European Journal of Social Theory, 13 (3):363-371.

Fungo, B. (2011). A review crop raiding around Protected Areas: nature, control and research gaps. Environmental research journal, 5(2), 87-92. 
Giraut, F., Guyot, S., \& Houssay-Holzschuch, M. (2004). 'Les aires protégées dans les recompositions territoriales africaines'. L'information géographique, Armand Colin, pp.340368.

Glaser, B. G., \& Strauss, A. L. (1967). The Discovery of Grounded Theory: Strategies for Qualitative Research. Chicago: Aldine.

Glaser, B. G. (1978). Theoretical Sensitivity: Advances in the Methodology of Grounded Theory. Mill Valley, California: Sociology Press

Glaser, B. G. (2001). The Grounded Theory Perspective: Conceptualization Contrasted With Description. Mill Valley, California: Sociology Press

Glaser, B. G. (2009). The novice GT researcher. The Grounded Theory Review, 8(2), 1-21.

Government of Rwanda. (GoR). (2009). Fourth national report to the convention on biological diversity; Rwanda Environment Management Authority; Ministry of Natural Resources, Kigali-Rwanda.

Government of Rwanda. (GoR). (2014). Fifth National Report to the Convention on Biological Diversity. Kigali, Rwanda. Rwanda Environment Management Authority; Ministry of Natural Resources, Kigali.

Government of Rwanda. (GoR). (2017). Country Profile. Kigali, Rwanda

Government of Rwanda. (GoR). (2018). 'Government Cabinet Meeting'. Kigali, Rwanda.

Grace, A. (2019). Assessment of abundance, distribution and threats on Prunus Africana in Rwanda, Case Study: Nyungwe and Gishwati-Mukura National Parks. Final Report.

Gross-Camp, N. D., Martin, A., McGuire, S., \& Kebede, B. (2015). The privatization of the Nyungwe National Park Buffer Zone and implications for adjacent communities. Society \& Natural Resources, 28(3), 296-311.

Harich, F. K., Treydte, A. C., Sauerborn, J., \& Owusu, E. H. (2013). People and wildlife: Conflicts arising around the Bia Conservation Area in Ghana. Journal for nature conservation, 21(5), 342-349.

Hausner, V., Fauchald, P. \& Jernsletten, J.-L. (2012). Community-based management: Under what conditions do Sámi pastoralists manage pastures sustainably? PLoS ONE 7:e51187.

Hill, C. M. (2004). Farmers' perspectives of conflict at the wildlife-agriculture boundary: some lessons learned from African subsistence farmers. Human Dimensions of Wildlife, 9(4), 279286. 
Holland, T.G., Peterson, G.D. \& Gonzalez, A. (2009). A cross-national analysis of how economic inequality predicts biodiversity loss. Conservation Biology, 23, 1304-1313.

Hoverman, S., Ross, H., Chan, T., \& Powell, B. (2011). Social learning through participatory integrated catchment risk assessment in the Solomon Islands. Ecology and Society, 16(2).

Hulme, D. \& Murphree, M. (2001). African Wildlife and Livelihoods: The Promise and Performance of Community Conservation. Oxford: James Currey Ltd.

Huxley, J. (1961). The conservation of wildlife and natural habitats in Central and East Africa. Paris: UNESCO.

Ikeme, J. (2003). Equity, environmental justice and sustainability: incomplete approaches in climate change politics. Global environmental change, 13(3), 195-206.

Imanishimwe, A., Niyonzima, T., \& Nsabimana, D. (2018). Contribution of Community Conservation and Ecotourism Projects on Improving Livelihoods and Sustainable Biodiversity Conservation in and around Nyungwe National Park (NNP). J Tourism Hospit, 7(363), 2167-0269.

Irland, L. C. (2008). State failure, corruption, and warfare: challenges for forest policy. Journal of Sustainable Forestry, 27(3), 189-223.

International Union for Conservation of Nature. (IUCN). (2004). 2003 Durban World Parks Congress. Parks 14:6.

Jennings, G. (2001). Tourism Research. Queensland, Australia: John Wiley and Sons

Jones, S. (2006). A Political Ecology of Wildlife Conservation in Africa. In: Review of African Political Economy, no. 33 (109), 483-495.

Kabore, A. 2010. 'Brousse des uns, aire protégée des autres. Histoire du peuplement, perceptions de la nature et politique des aires protégées dans le Gourmaburkinabè: l'exemple de la Réserve partielle de faune de Pama'. Thèse de Doctorat. Institut de Hautes Etudes Internationales (Genève) et du Développement.

Kambogo, I., \& Bizimana, J. P. (2016). Tourists' preferences for ecotourism planning and development around Nyungwe National Park, Rwanda. Rwanda Journal, 1(1S).

Kamuzinzi, P. K., Shukla, J. \& Ndabaga, E. (2015). The effectiveness of Rwanda Development Board tourism revenue sharing program towards local community socio-economic development: A case study of Nyungwe National Park. European Journal of Hospitality and Tourism Research, 3(2), 47-63. 
Kapoor, I., (2001). Towards participatory environmental management? Journal of Environmental Management, 63, 269-279.

Kasisi, R. (2012). Les perspectives de la biodiversité en Afrique subsaharienne: repenser collectivement le modèle de gestion. VertigO- La revue électronique en sciences de l'environnement, 12(2).

Karanth, K. K., Naughton-Treves, L., DeFries, R., \& Gopalaswamy, A. M. (2013). Living with wildlife and mitigating conflicts around three Indian protected areas. Environmental management, 52(6), 1320-1332.

Kennedy, B. L., \& Thornburg, R. (2018). Deduction, induction, and abduction. The SAGE handbook of qualitative data collection, 49-64.

Khan, S. N. (2014). Qualitative research method-phenomenology. Asian Social Science, 10(21), 298

Kipkeu, M. L., Mwangi, S. W., \& Njogu, J. (2014). Community participation in wildlife conservation in Amboseli Ecosystem, Kenya. Journal of Environmental Science, Taxicology and Food Technology, 8(4), 68-75.

Kowal, S. \& O’Connell, D. C. (2014). Transcription as a crucial step of data analysis. In U. Flick (Ed.), The handbook of qualitative analysis (pp.64-78). Thousand Oaks, California: Sage Publications.

Kuckartz, U. (2010). Realizing mixed methods approaches with MAXQDA. Marburg, Germany: Philipps-University Marburg.

Kumar, R. (2011). Research methodology: A step-by-step guide for beginners. London: SAGE

Larsson, S. (2009). A pluralist view of generalization in qualitative research. International Journal of Research \& Method in Education, 32(1), 25-38.

Laudati, A. A. (2010). The encroaching forest: struggles over land and resources on the boundary of Bwindi Impenetrable National Park, Uganda. Society and Natural Resources, 23(8), 776789.

Leciejewski, M., \& Perkins, H. A. (2015). Environmental justice in Appalachia: Procedural inequities in the mine permitting process in Southeast Ohio. Environmental Justice, 8(4), 111-116.

Lele, S., Wilshusen, P., Brockington, D., Seidler, R., \& Bawa, K. (2010). Beyond exclusion: alternative approaches to biodiversity conservation in the developing tropics. Current Opinion in Environmental Sustainability, 2(1-2), pp.94-100. 
Li, Y. (2004). Exploring community tourism in China: the case of Nanshan tourism zone. Journal of Sustainable Tourism, 12 (3), 175-193

Li, W. (2005). Community decision-making: participation in development. Annals of Tourism Research, 33 (1), 132-143.

Lin L-Z, C-F L (2013). Fuzzy group decision-making in the measurement of ecotourism sustainability potential. Gr DecisNegot 22, 1051-1079

Lindenmayer, D., Thorn, S. \& Noss, R. (2017). Countering resistance to protected-area extension. Conservation Biology, 1-19.

Mack, N., Woodsong,C., MacQueen, K.M., Guest, G. \& Namey, E. (2005). Qualitative Methods: A data collector's field guide. Family Health International. Research Triangle Park, Carolina, USA: Retrieved from https://www.fhi360.org/resource/qualitative-research-methods-datacollectors-field-guide: Accessed on 6-8-2020

Mc Guinness, S., \& Taylor, D. (2014). Farmers' perceptions and actions to decrease crop raiding by forest-dwelling primates around a Rwandan forest fragment. Human dimensions of wildlife, 19(2), 179-190.

McLellan, E., MacQueen, K. M., \& Neidig, J. L. (2003). Beyond the qualitative interview: Data preparation and transcription. Field methods, 15(1), 63-84.

MacMillan, J. \& Schumacher, S. (2014). Research in education: Evidence-based inquiry (7th Ed.). Harlow, United Kingdom: Pearson.

McShane, T. O., \& Newby, S. A. (2004). Expecting the unattainable: the assumptions behind ICDPs. In Getting biodiversity projects to work: Towards more effective conservation and development, 49-74. New York: Colombia Univ Press.

Macura, B., Secco, L. \& Pullin, A.S. (2015). What evidence exists on the impact of governance type on the conservation effectiveness of forest protected areas? Knowledge base and evidence gaps. Environmental Evidence, 4, 24. BioMed Central.

Mahonge, C. P. (2010). Co-managing complex social- ecological systems in Tanzania, The case of Lake Jipe Wetland. Environmental Policy Series, Vol. 2. Wageningen, Netherland: Wageningen Academic Publishers

Manu, I., \& Kuuder, C. (2012). Community-based ecotourism and livelihood enhancement in Sirigu. Ghana, 24, 2-18. 
Martin, A., Gross-Camp, N., Kebede, B., \& McGuire, S. (2014). Measuring effectiveness, efficiency and equity in an experimental Payments for Ecosystem Services trial. Global Environmental Change, 28, 216-226.

Mathis, A., \& Rose, J. (2016). Balancing tourism, conservation, and development: a political ecology of ecotourism on the Galapagos Islands. Journal of Ecotourism, 15(1), 64-77.

Mason, J. (2018). Qualitative researching ( $3^{\text {rd }}$ ed.). London; Thousand Oaks, California: SAGE

Masozera, M. K. (2002). Socioeconomic impact analysis of the conservation of the Nyungwe forest reserve, Rwanda. Doctoral dissertation, University of Gainesville, Florida.

Masozera, M. K., \& Alavalapati, J. R. (2004). Forest dependency and its implications for protected areas management: a case study from the Nyungwe Forest Reserve, Rwanda. Scandinavian Journal of Forest Research, 19(S4), 85-92.

Maxwell, J. A. (2012). Qualitative research design: An interactive approach. London: Sage.

Mayring, P. (2014). Qualitative content analysis: theoretical foundation, basic procedures and software solution. URN: http://nbn-resolving.de/urn:nbn:de:0168-ssoar-395173. Accessed on 28 July 2019

Mensah, J., \& Casadevall, S. R. (2019). Sustainable development: Meaning, history, principles, pillars, and implications for human action: Literature review. Cogent Social Sciences, 5(1), 1653531 .

Merriam, S. B. (2009). Qualitative case study research. In Qualitative research: A guide to design and implementation (pp. 39-54). San Francisco, CA: Jossey-Bass.

Michalski, F., Boulhosa, R. L. P., Faria, A., \& Peres, C. A. (2006). Human-wildlife conflicts in a fragmented Amazonian forest landscape: Determinants of large felid depredation on livestock. Animal Conservation, 9(2), 179-188. https://doi.org/10.1111/j.14691795.2006.00025.x Accessed on 28 July 2020

Michels, A. M. (2006). Citizen participation and democracy in the Netherlands. Democratization, 13(02), 323-339.

Mikkelsen, B. (2005). Methods for development work and research: a new guide for practitioners $\left({ }^{2 n d} e d\right)$. California, USA: SAGE.

Miller, T. R., Minteer, B. A., \& Malan, L. C. (2011). The new conservation debate: the view from practical ethics. Biological Conservation, 144(3), 948-957. 
Mohd, A., Jusoff, K., Sheikh, A. H., Yaman, A. R. (2009). The management of Bhawal National Park, Bangladesh by the local community for resource protection and ecotourism. Asian Soc Sci, 4, 101-107

Morshed, H. M. (2013). Benefits and Weaknesses of Collaborative Management: A Case Study in the Rema-Kalenga Wildlife Sanctuary. Connecting Communities and Conservation: Comanagement Initiatives Implemented by IPAC in Wetlands and Forests of Bangladesh, 102.

Moswete, N., Thapa, B., \& Darley, W. K. (2020). Local Communities’ Attitudes and Support Towards the Kgalagadi Transfrontier Park in Southwest Botswana. Sustainability, 12(4), 1524.

Mugisha, A. R. (2002). Evaluation of community-based conservation approaches: management of protected areas in Uganda (Doctoral dissertation, University of Florida). Nantonga, USA.

Mulindahabi, F., \& Ndikubwimana, I. (2010). Monitoring Threats to Biodiversity in Nyungwe National Park, Rwanda. Ranger-based Monitoring Report Year 2010. Wildlife Conservation Society Rwanda and Rwandan Development Board Tourism \& Conservation, Kigali, Rwanda.

Munanura, I. E., Backman, K. F., Hallo, J. C., \& Powell, R. B. (2016). Perceptions of tourism revenue sharing impacts on Volcanoes National Park, Rwanda: a sustainable livelihoods framework. Journal of Sustainable Tourism, 24(12), 1709-1726.

Munanura, I. E., Backman, K. F., Sabuhoro, E., Powell, R. B., \& Hallo, J. C. (2018). The perceived forms and drivers of forest dependence at Volcanoes National Park, Rwanda. Environmental Sociology, 4(3), 343-357.

Munene Ndereba, I. (2017). The movement for community- led development. Lessons from Rwanda. Retrieved from https://communityleddev.org/2017/06/27/lessons-fromdecentralization-in-rwanda/ Accessed on 26 July 2019

Myers, N., Mittermeier, R. A., Mittermeier, C. G., Da Fonseca, G. A., \& Kent, J. (2000). Biodiversity hotspots for conservation priorities. Nature, 403(6772), 853-858.

National Institute of Statistics of Rwanda. (NISR). (2012). EICV4. Rwanda Fourth Population and Housing Census. Thematic Report: Population Projection. Kigali-Rwanda National Institute of Statistics of Rwanda. (NISR). (2018). EICV5: The fifth integrated household living conditions survey. Thematic Report: Economic Activity. Kigali-Rwanda

Naughton-Treves, L. (1998). Predicting patterns of crop damage by wildlife around Kibale National Park, Uganda. Conservation biology, 12(1), 156-168. 
Nepal, S. K., \& Weber, K. E. (1995). Prospects for coexistence: wildlife and local people. Ambio, 238-245.

Newig, J., \& Fritsch, O. (2009). Environmental governance: participatory, multi-level-and effective. Environmental policy and governance, 19(3), 197-214.

Nibeza, S., \& Tumusherure, W. (2015). The impact of monetary policy on Rwanda's economy: analysis of vector error correction model (1980-2006). International Journal of Contemporary Applied Sciences, 2(5), 2308-2365.

Nilsson, M., Griggs, D., \& Visbeck, M. (2016). Policy: map the interactions between Sustainable Development Goals. Nature, 534(7607), 320-322.

Nykiel, R. A. (2007). Handbook of marketing research methodologies for hospitality and tourism. New York, USA: Routledge

Office Rwandaise de Tourisme et des Parcs Nationaux. (ORPN). (2004). Strategic Plan 20042008. Kigali-Rwanda

Ogra, M., \& Badola, R. (2008). Compensating human-wildlife conflict in protected area communities: ground-level perspectives from Uttarakhand, India. Human Ecology, 36(5), 717.

Ojha, H. R., Ford, R., Keenan, R. J., Race, D., Vega, D. C., Baral, H., \& Sapkota, P. (2016). Delocalizing communities: Changing forms of community engagement in natural resources governance. World Development, 87, 274-290.

O’Neil, T., \& Domingo, P. (2015). The Power to Decide: Women, Decision-making and Gender Equality. London: The Overseas Development Institute (ODI).

Organization for Economic Co-operation and Development. (OECD). (2014). Women, Government and Policy Making in OECD Countries: Fostering Diversity for Inclusive Growth. OECD Publishing.

Ormsby, A., \& Kaplin, B. A. (2005). A framework for understanding community resident perceptions of Masoala National Park, Madagascar. Environmental Conservation, 156-164. ORTPN, (2005). Tourism Revenue Sharing in Rwanda, policy and Guidelines: Kigali-Rwanda

Ostrom, E. (1990). Governing the commons: The evolution of institutions for collective action. New York: Cambridge University Press.

Otto, J., Zerner, C., Robinson, J., Donovan, R., Lavelle, M., Villarreal, R., \& Pearl, M. (2013). Natural connections: perspectives in community-based conservation. Washington, D.C; Covelo, California: Island Press. 
Patton, M. Q. (2002). Qualitative Research and Evaluation Methods. Thousand Oaks, California: Sage

Paudel, N. R. (2009). A critical account of policy implementation theories: status and reconsideration. Nepalese Journal of Public Policy and Governance, 25(2), 36-54.

Peluso, N. L. (1992). Rich forests, poor people: Resource control and resistance in Java. Berkeley, Los Angeles, Oxford: University of California Press.

Peluso, N. L. (1993). Coercing conservation: The politics of state resource control. Global environmental change, 3(2), 199-217.

Pemunta, N. V. (2019). Fortress conservation, wildlife legislation and the Baka Pygmies of southeast Cameroon. GeoJournal, 84(4), 1035-1055.

Plumptre, A. J. (2012). The Ecological Impact of Long-term Changes in Africa's Rift Valley. New York: Nova Science Publishers.

Plumptre, A. J., Kayitare, A., Rainer, H., Gray, M., Munanura, I., Barakabuye, N., ... \& Namara, A. (2004). The socio-economic status of people living near protected areas in the Central Albertine Rift. New York: Wildlife Conservation Society (WCS)

Poteete, A. R., \& Ostrom, E. (2004). Heterogeneity, group size and collective action: The role of institutions in forest management. Development and change, 35(3), 435-461.

Pretty, J. N. \& Pimbert, M.P. (1995). Beyond conversation ideology and the wilderness myth. Natural Resources Forum, Vol. 19(1), 5-14.

Pretty, J. (1995). The many interpretations of participation. Focus, vol.16, 4-5

Rahman, M. S. (2017). The Advantages and Disadvantages of Using Qualitative and Quantitative Approaches and Methods in Language" Testing and Assessment" Research: A Literature Review. Journal of Education and Learning, 6(1), 102-112.

Rattan, J. K., Eagles, P. F., \& Mair, H. L. (2012). Volunteer tourism: Its role in creating conservation awareness. Journal of Ecotourism, 11(1), 1-15.

Reddy, G.N., (2002). Empowering Communities through Participatory Methods. Delhi: Manak Publications

Redoano, M., \& Scharf, K. A. (2004). The political economy of policy centralization: direct versus representative democracy. Journal of Public Economics, 88(3-4), 799-817.

Reed, M. S., Fraser, E. D., \& Dougill, A. J. (2006). An adaptive learning process for developing and applying sustainability indicators with local communities. Ecological economics, 59(4), 406-418. 
Reed, M. S., Dougill, A. J., \& Taylor, M. J. (2007). Integrating local and scientific knowledge for adaptation to land degradation: Kalahari rangeland management options. Land Degradation \& Development, 18(3), 249-268.

Reed, M. S. (2008). Stakeholder participation for environmental management: a literature review. Biological conservation, 141(10), 2417-2431.

REMA, (2011). Rwanda Biodiversity Policy. Kigali- Rwanda

REMA, (2015). Study to establish a national list of threatened terrestrial ecosystems and species in need of protection in Rwanda. Kigali, Rwanda.

Republic of Rwanda, (2005). Organic law $n^{\circ}$ 04/2005 determining the modalities of protection, conservation and promotion of environment in Rwanda, (O.G. $\mathrm{n}^{\circ} 09$ of 01/05/2005).

Ribot, J. C. (2002). Democratic Decentralization of Natural Resources: Institutionalizing Popular Participation: Washington DC: World Resources Institute

Rice, J. (2007). Ecological unequal exchange: Consumption, equity, and unsustainable structural relationships within the global economy. International Journal of Comparative Sociology, 48(1), 43-72.

Richmond, A. K., Malcomb, D., \& Ringler, K. (2015). Household vulnerability mapping in Africa's Rift Valley. Applied Geography, 63, 380-395.

Robbins, P. (2004). Political Ecology: A Critical Introduction. Oxford. U.K: Blackwell Publishing.

Roe, D. (2004): Poverty reduction and biodiversity conservation: Rebuilding the bridges; Oryx 38(2) 137-139.

Roudgarmi, P. (2011). Qualitative research for environmental sciences: A review. Journal of Food, Agriculture \& Environment, 9(3\&4), 871-879.

Rutebuka, E., Nsabimana, D., \& Gross-camp, N. D. (2012). Evaluation of community-based conservation around protected areas in Rwanda, Nyungwe National Park. In Student Conference on Conservation Science, (pp. 1-8).

Rwanda Development Board. (2014). Annual Tourism Report 2013. Kigali-Rwanda

Rwanda Development Board. (RDB). (2017). Annual Report. Kigali- Rwanda.

Rwanda Development Board. (2012). Nyungwe National Park Management Plan 2012-2021. Kigali-Rwanda

Rwanda Development Board. (2011). The Nyungwe National Park Management Plan 2012-2021. Kigali-Rwanda 
Saarinen, J. (2006). Traditions of sustainability in tourism studies. Annals of tourism research, 33(4), 1121-1140.

Salafsky, N., Cauley, H., Balachander, G., Cordes, B., Parks, J., Margoluis, C., ... \& Margoluis, R. (2001). A systematic test of an enterprise strategy for community-based biodiversity conservation. Conservation biology, 15(6), 1585-1595.

Savin-Baden, M. \& Major, C. H. (2013). Qualitative research: The essential guide to theory and practice. London \& New York: Routledge

Saayman, M., \& Saayman, A. (2006). Estimating the economic contribution of visitor spending in the Kruger National Park to the regional economy. Journal of sustainable tourism, 14(1), 6781.

Scherl, L. M., Wild, R., \& Wilson, A. (2004). Can protected areas contribute to poverty reduction: opportunities and limitations. Gland, Switzerland and Cambridge, UK: IUCN

Scholte, J. A. (2010). Governing a more global world. Corporate Governance: International Journal of Business in Society, 10(4), 459-474.

Schlosberg, D. (2007). Justice to Nature 2: Incorporating Recognition, Capabilities, and Participation: Oxford, Ney York: Oxford University Press.

Schreier, S. (2014). Qualitative content analysis. In U. Flick (Ed.), The handbook of qualitative analysis (pp.170-183). London: Sage.

Sheppard, B.H., Lewicki, R.J., \& Minton, J.W. (1992). Organizational Justice: The Search for Fairness in the Workplace. New York: Lexington Books.

Silverman, D. (2005). Doing qualitative research. A practical handbook. London: Sage Publications.

Silverman, D. (2006). Interpreting qualitative data ( $3^{\text {rd }}$ ed.). Methods for analyzing talk, text and interaction. London: Sage.

Silverman, D. (2014). Interpreting qualitative data ( $4^{\text {th }} e d$.). Los Angeles, London, New Delhi, Singapore \& Washington, D. C: Sage.

Sitati, N. W., Walpole, M. J., \& LEADER-WILLIAMS, N. (2005). Factors affecting susceptibility of farms to crop raiding by African elephants: using a predictive model to mitigate conflict. Journal of applied ecology, 42(6), 1175-1182.

Siurua, H. (2006). Nature above people: Rolston and" fortress" conservation in the South. Ethics and the Environment, 71-96. 
Svarstad, H., Sletten, A., Paloniemi, R., Barton, D. N., \& Grieg-Gran, M. (2011).'Three types of environmental justice: From concepts to empirical studies of social impacts of policy instruments for conservation of biodiversity'. Assessing the Role of Economic Instruments in Policy Mixes for Biodiversity Conservation and Ecosystem Services Provision, Report for the Policymix Project. Oslo: Norwegian Institute for Nature Research.

Songorwa, A. N. (1999). Community-based wildlife management (CWM) in Tanzania are the communities interested. World development, 27(12), 2061-2079.

Spiteri, A., \& Nepalz, S. K. (2006). Incentive-based conservation programs in developing countries: a review of some key issues and suggestions for improvements. Environmental Management, 37(1), 1-14.

Stern, M. J. (2008). The power of trust: toward a theory of local opposition to neighboring protected areas. Society and Natural Resources, 21(10), 859-875.

Stern, P. C., \& Dietz, T. (2008). Public participation in environmental assessment and decision making. Washington, D. C: National Academies Press.

Taneja, S. S., Taneja, P. K., \& Gupta, R. K. (2011). Researches in corporate social responsibility: A review of shifting focus, paradigms, and methodologies. Journal of Business Ethics, 101(3), 343-364.

Thornberg, R., Perhamus, L., \& Charmaz, K. (2014). Grounded theory. Handbook of research methods in early childhood education: Research methodologies, 1, 405-439.

Timothy, D. J. (1999). Participatory planning a view of tourism in Indonesia. Annals of tourism research, 26(2), 371-391.

Tosun, C. (1999). Towards a typology of community participation in the tourism development process. Anatolia: An International Journal of Tourism and Hospitality Research, 10(2), 113134.

Tosun, C. (2000). Limits to community participation in the tourism development process in developing countries. Tourism management, 21(6), 613-633.

Tosun, C. (2006). Expected nature of community participation in tourism development. Tourism management, 27(3), 493-504.

Triplet, P. (2009). Manuel de gestion des aires protégées d'Afrique francophone. Paris: Awely.

Trippas, J. R., Spina, D., Cavedon, L., \& Sanderson, M. (2017). A conversational search transcription protocol and analysis. In Proc of SIGIR 1st International Workshop on Conversational Approaches to Information Retrieval (CAIR'17), CAIR (Vol. 17). 
Tusabe, R., \& Habyalimana, S. (2010). From Poachers to Park Wardens: Revenue Sharing Scheme as an incentive for environment protection in Rwanda. In Mountain Forum Bulletin, 10(1), 91-93.

Umuziranenge, G. (2019)1. Parks' governance and management in Rwanda: Opportunities and challenges of the community participation for a sustainable conservation - Case study of Nyungwe National Park. International Journal of Environmental Protection and Policy, $7(2): 61-71$.

Umuziranenge, G. (2019)2. Environmental justice and women empowerment in Nyungwe National Park (Rwanda): Case study of Kitabi Women Handcrafts Cooperative. International Journal of Environment and Climate Change, 9(2), 77-87.

Umuziranenge, G., \& Muhirwa, F. (2017) 3. Ecotourism as potential conservation incentive and its impact on community development around Nyungwe National Park (NNP): Rwanda. Imperial Journal of Interdisciplinary Research, 3(10), 447-455.

Uphoff, N. T., Cohen, J. M., \& Goldsmith, A. A. (1979). Feasibility and application of rural development participation: A state-of-the-art paper. New York: Cornell University.

Walpole, M. J., \& Thouless, C. R. (2005). Increasing the value of wildlife through nonconsumptive use? Deconstructing the myths of ecotourism and community-based tourism in the tropics. Conservation Biology Series 9, 122.

Ward, C., Holmes, G., \& Stringer, L. (2018). Perceived barriers to and drivers of community participation in protected-area governance. Conservation Biology, 32(2), 437-446.

Western, D. \& Wright, R.M, \& Strum, S.C. (1994). Natural Connections; Perspectives on Community-Based Conservation. Washington, D. C: Island Press.

Wijayaratna, C.M., (2004). Role of local communities and institutions in integrated rural development. In Wijayaratna, C.M. (Ed.), Role of local communities and institutions in integrated rural development (pp. 34-62).

Willis, A. K. (1999). Breaking through barriers to successful empowerment. Hospital Materiel Management Quarterly, 20(4), 69-80.

Zacarias, D., \& Loyola, R. (2017). How ecotourism affects human communities. In: Blumtein DT, Geffroy B, Samia DSM, Bessa E (eds) Ecotourism's promise and peril: A biological evaluation. Springer, Cham. pp. 133-151 
Zhao, W., \& Ritchie, J. B. (2007). Tourism and poverty alleviation: An integrative research framework. Current Issues in Tourism, 10(2-3), 119-143. 
APPENDICES 


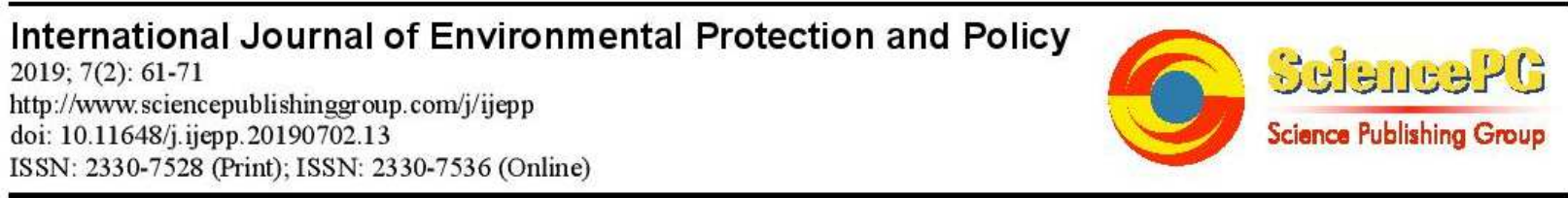

\title{
Parks' Governance and Management in Rwanda: Opportunities and Challenges of the Community Participation for a Sustainable Conservation - Case Study of Nyungwe National Park
}

\author{
Gloriose Umuziranenge \\ Department of Natural Resources and Environment Management, Protestant Institute of Arts and Social Science, Huye, Rwanda \\ Email address: \\ gloris06alyahoo.fr
}

\section{To cite this article:}

Gloriose Umuziranenge. Parks' Governance and Management in Rwanda: Opportunities and Challenges of the Community Participation for a Sustainable Conservation - Case Study of Nyungwe National Park. International Journal of Environmental Protection and Policy.

Vol. 7, No. 2, 2019, pp. 61-71. doi: 10.11648/j.ijepp. 20190702.13

Received: February 26, 2019; Accepted: April 2, 2019; Published: May 10, 2019

\begin{abstract}
In the field of conservation, the shift from the fortress conservation approach towards participatory management has considerably increased the interest for tourism activities and income. In Rwanda, the protected areas governance system is promoting community-based conservation through tourism revenue sharing to achieve conservation and development goals. The case study was designed to: (1) assess the understanding and implementation of principles of community participation by different stakeholders for the benefit of local communities and the efficiency of the conservation and (2) define interactive dynamics and conditions created for fully and sustainably population involvement in the conservation. The study area was selected because of its rich biodiversity and the high dependence of surrounding populations on natural resources. The study adopted a qualitative approach based on semi-structured individual interviews to key stakeholders from different categories of stakeholders including local communities. The data collected were transcribed, translated and analyzed using content analysis methods, MAXQDA Software and a coding system. The results showed that the involvement and empowerment of local people are done through keen activities based cooperative associations and funded projects, reference made to resources use, awareness raising and skills for interactions, cooperative spirit promotion and entrepreneurship. They indicated that the level of communities' participation remains only of procedural kind and is still low though community members are benefiting of jobs, loans for their projects and income generating activities such as organized productions for market thanks to tourism revenue sharing and revolving fund programs. The transfer of the management is slow and smooth because of a slow change of mindset from receiving mentality, farming related difficulties, unaffordable lending conditions and a great deal of communication and misunderstanding on the tourism revenue sharing and the projects funding approaches. Contradictory understandings and appreciations of the community participation are recorded according to the categories of stakeholders. Actually, all the administrative and technical processes including mediation between communities and funding agencies are driven through a top-down management model; the study area being a state owned and controlled park and not a co-managed one. Though local communities gradually understand the role of the park thanks to income generating activities and community projects, the new approach does not meet basic criteria for effective community participation to ensure the sustainability of the conservation. However, the socio-economic incentives have a positive impact on the reduction of illegal activities and threats, except poaching for which a compensation fund for damaged crops was created.
\end{abstract}

Keywords: Nyungwe National Park, Community Participation, Natural Resources Management, Tourism Revenue Sharing, Rwanda 


\section{Introduction}

Historically, the nature conservation paradigm started within the protectionism approach which denied the local communities to participate in conservation activities and people to use protected natural resources for their basic needs [1]. For a long time, the approach was perceived as the best one to achieve nature conservation [2]. In Africa and in Rwanda, it expanded so quickly that local livelihood strategies and activities like farming activities, cattle grazing and hunting were declared as illegal [3].

In protected areas which were delimited and placed under state control, customary rights were ignored [4] and human impact was monitored. The protectionism approach failed to achieve its goals for many reasons among which a high reliance of local communities to natural resources and a high rate of poverty $[5,6]$. In the 1980 's, a new conservation approach called "People-centred conservation", "Community based conservation" or "Participatory approach" $[7,8]$ appeared with the aim of reconciling conservation and local development [9] by involving local people in sharing the financial benefits of projects and in the total process of natural resource management. In recent years, different models of "community based conservation" programs (CBC) linking the conservation to the alleviation of rural poverty through socio-economic welfare initiatives and community participation were undertaken [10], especially in favor of previously neglected people around protected areas [11].

These experiences of co-management and bottom up approach in policy making $[2,12,13]$ are being constrained by inadequate government resources, weak management capacities and ineffective legal systems [14]. The values and processes of community based conservation cannot be achieved without education, awareness raising, community mobilization and job creation that allow people to increase knowledge and capabilities to influence decisions [15]. Actually, local communities are often involved at a stage of implementation, not in the whole process like project identification, preparation, monitoring and evaluation $[16$, $17,18,19,20]$.

The success of the community participation depends on how it considers the new power relations and inclusivity [21]. In Rwanda, this conservation approach was promoted for the following reasons: (1) the country has the highest population density in Africa which is 350 people $/ \mathrm{km}^{2}$ [22], (2) over $90 \%$ of the population is engaged in subsistence agriculture, (3) natural resources such as forests, land and water are vital to country individuals' occupations [23] and (4) people living inside and around protected areas are among the poorest citizens and bring increased pressure and degradation [24].

Since 1998, indeed, a decentralization policy aiming at ensuring democratic governance, accountability and local community participation in decision making was adopted. Community participation was envisioned as one of the benefits of decentralization as citizens sought greater input in matters affecting them [25]. In the field of nature conservation, an organic law was voted in 2005 for the management and utilization of protected areas and environmental resources [26] involving local communities, local authorities, public and private institutions and Non Governmental Organizations (NGOs). Given the great potential and the quick growth of eco-tourism industry in terms of revenues, many people including decision makers believe that the tourism sector can better help to achieve socio-economic development at local community level.

The new law and management scheme and related regulations were entrusted in Rwanda Development Board (RDB). The Rwandan Office of Tourism and National Parks (ORTPN) started a tourism income sharing plan whereby $5 \%$ of the aggregate Gross Revenue is gathered into a national pool and appropriated to the parks at various proportions: $40 \%$ to Volcano National Park, $30 \%$ to Akagera National Park and $30 \%$ to Nyungwe National Park [27]. Since 2017, the funds available to support the revenue share program increased from $5 \%$ to $10 \%$ of all tourism revenue. The amount goes back to the communities surrounding the 3 national parks. The Tourism Revenue Sharing is intended to induce local population's ownership and benefit from those parks.

The program assists local communities living adjacent to national parks in the construction of infrastructures like schools, dispensaries, water supply, food security and other income generating activities [28]. Through the program, $\mathrm{RDB}$ supports projects that benefit development and welfare of local communities and involves them in conservation activities, including being park rangers and guides of the parks. The scheme is conducted through cooperatives starting from people who were involved in illegal activities from the past. From 2005 to 2018 , over US\$1.28 million has been spent on more than 158 community-based projects in three main national parks mentioned above. However, little is known about the community perceptions towards their involvement in Tourism Revenue Sharing scheme administrated by Rwanda Development Board (RDB).

The present study aimed to examine the community participation in natural resources management by focusing on: (1) how communities understand community participation approach, (2) how they are empowered to participate in conservation, understanding the benefits that they could receive as neighbors of protected areas, challenges that hinder them in participating in natural resources management and strategies to overcome those challenges. It intended to investigate whether during the implementation of the law's new provisions, the involvement of local community is genuinely and professionally done both to meet the expectations of the community and to achieve its purposes.

As specific goals, it aims to: (1) assess how participation as a tool of good governance in conservation and natural resources management is understood and perceived by the community around national parks, (2) identify the challenges that hinder them to participate fully and efficiently in the management of national parks and (3) suggest ways for improvement of the community participation in the 
conservation and the management of national parks. Given its ecological importance as a mountainous rainforest and the great surrounding pressures and degradation, the Nyungwe National Park (NNP) was chosen to be the study area considering a period of 13 years running from 2005 when the new management system was set up to 2018 .

\section{Methodology}

\subsection{Study Area}

The Nyungwe National Park (NNP) is one of the three national parks of Rwanda. It is located in South West of the Country. It is surrounded by 4 Districts that are Nyamasheke, Rusizi Nyaruguru and Nyamagabe as indicated in Figure 1 and 36 Sectors. NNP resulted from the erection of the former Nyungwe Natural Forest Reserve under the law $n^{\circ} 22 / 2005$ of November 21, 2005 setting up new management schemes which prevent different activities by many different groups to stop.

The Park includes Cyamudongo and Gisakura Natural Forests. Until 2005, it is the Wildlife Conservation Society (WCS) that was in charge of the full management of the Nyungwe Natural Reserve. The NNP is a high-altitude mountainous rainforest along the Albertine Rift covering approximately $1,019 \mathrm{~km}^{2}$. It is the largest mountainous forest remaining in Africa and home to $20 \%$ of all African primates, including 13 primate species, as well as $280 \mathrm{bird}$ species including 25 endemic ones; 43 species of reptiles, and 85 mammal species. The Park is also characterized by an extremely rich plant life with more than 240 species of orchids.

The NNP surrounding zones are very populated with a more or less 300 occupants $/ \mathrm{km}^{2}$. More than $90 \%$ of the local communities are subsistence farmers having an average cultivated area of less than 1 ha per household. Thanks to its important biodiversity, the NNP plays a big role in the surviving of the neighboring communities. It provides many ecosystemic services by means of water catchments for most of the communities and balances out soil disintegration and erosion for the surrounding communities. In terms of ecotourism, NNP is currently the second most prevalent nature based tourism fascination in Rwanda after the Volcano National Park. Guided strolls, chimpanzee following and recreational offices from Lake Kivu in this manner make the NNP special.

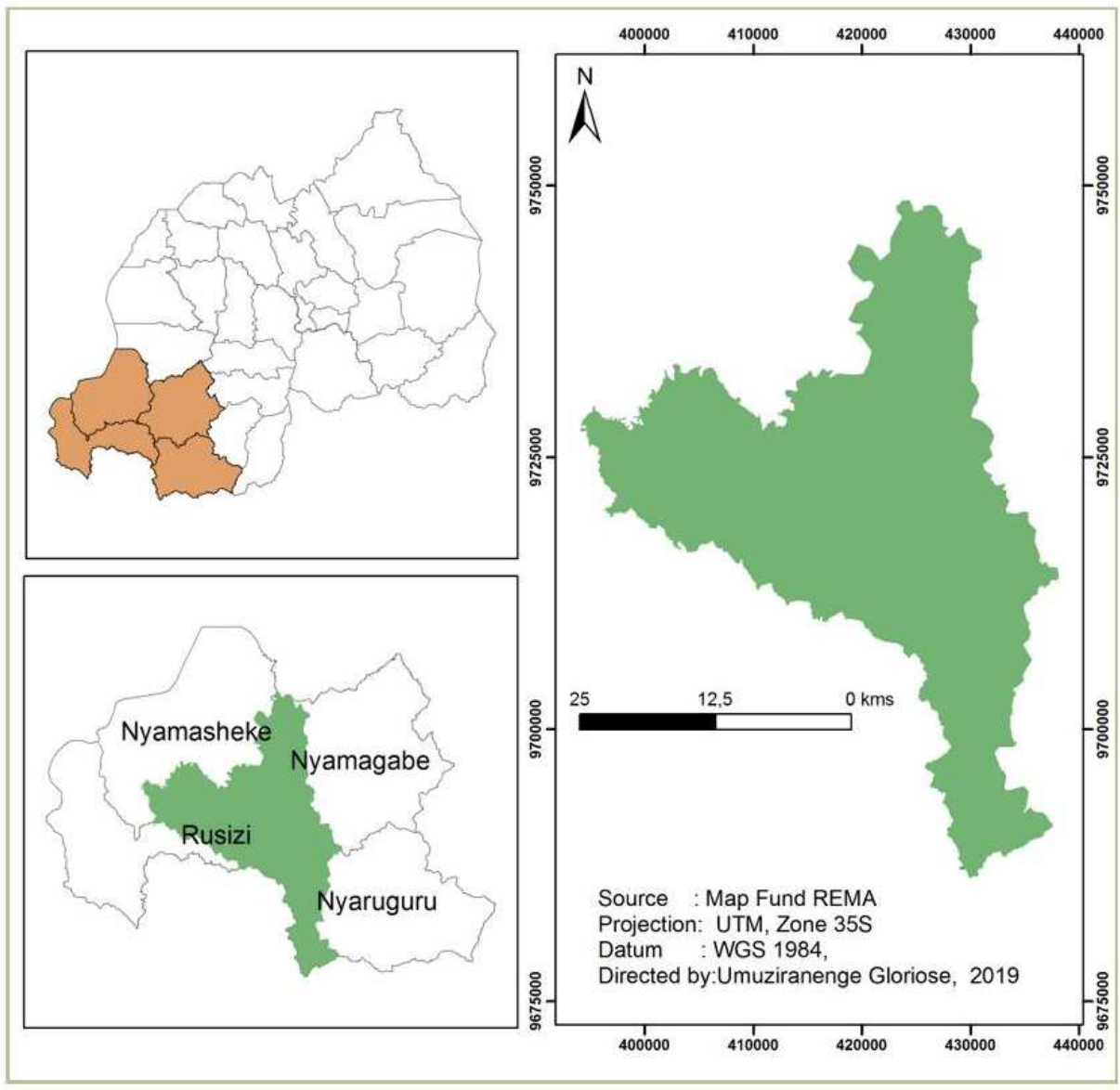

Figure 1. Localization map of the Nyungwe National Park. 
Since a long time tea plantations and mining activities are organized by internal villages where people were used to come for businesses and would degrade the forest [26]. Until the early 1990 's, more than 3.000 people were permanently living in the park and had built houses and shops in places like Pindura and Karamba [29]. The main challenges that NNP is facing are: (1) the increased population pressure, (2) a high rate of poverty of the surrounding populations, (3) a high reliance on natural resources, especially on agriculture for livelihoods, (4) important forest and bush fires, (5) hunting pressures on largest mammals, (6) artisanal and industrial mining and (7) deforestation for firewood, medicine, grass for cattle and construction materials [24, 30].

Around 360,000 people specifically fringe the recreation center. The main human threats to biodiversity include poaching, deforestation, bush fires, honey collection and mining activities [31]. These threats resulted in the disappearance of large mammals like elephants (Loxodonta africana) and buffalos (Syncerus caffer). The high percentage of poor and low educated people living around NNP is a big challenge for both tourism and conservation development [24].

\subsection{Research Approach and Methods}

The study started with secondary data collection and analysis. These ones were obtained through the literature available, annual reports and internet sources. In order to explore and take into consideration different views on the research issues, qualitative approach was adopted because it fits the purpose of the present study. With regard to sampling, theoretical and purposive samplings were used to progressively selected participants.

Five professional groups or stakeholders were selected for the study. Data collection relied on interview guides to members of communities and to key informants from public and private institutions. The participants to interviews were chosen among 5 categories: (1) conservation NGOs, (2) community leaders, (3) associations involved in Tourism and Conservation activities, (4) government officers in charge of conservation activities and (5) members of local community at associations' level including former miners, former poachers, artisans and beekeepers association around Kitabi and Nshili zones today.

Key interviews were conducted to further collecting full information. The individual interviewed are leaders of or from institutions like RDB, Wildlife Conservation Society (WCS), District Environmental Officers, NGO participating in community empowerment through training and loans for community projects, leaders of community associations, local leaders and district local government leaders. To approach the question about different stakeholders' views on community participation, semi-structured interviews were conducted to allow the interviewees the opportunity to express their personal experiences or views in their own words, which in turn allows the interviewer to gain the interviewee's perspective [32].

Therefore the research adopted a qualitative approach to gather the required primary data through individual semistructured interviews. In practice, qualitative approach is preferred when one seeks to explore how individuals interpret their experiences on a given matter [33, 34]. It focuses on understanding people's beliefs, perspectives, experiences, attitudes, opinions, perceptions about phenomena and situations or issues [35]. Participants for interviews during data collection were community leaders and community associations that were selected conveniently considering the one ready to be interviewed.

The key interviewed respondents were selected purposively based on their experience in working with the community and they include leaders in institutions like Rwanda Development Board (RDB), the Wildlife Conservation Society (WCS); the District environmental officers; the NGOS participating in community empowerment through training and loans for community projects; leader of community associations; local leaders and District local government leaders. For sampling techniques this research used a theoretical sampling where the choice of participants, data collection and analysis are done in parallel [33].

In this process, the size of the sample is not fixed. Rather, the sample size is determined by the saturation point when no new information is coming out [33,34]. The respondents of different categories were as interesting as they could present and explain official policies. Audio recording and notes taking were used for interviews. To ensure and promote privacy and confidentiality of the participants, each of them was assigned a code at the beginning of the interview. At the end, 20 participants representing different stakeholder groups were selected according to the repartition shown in Table 1 .

Table 1. Repartition of the participants to interviews.

\begin{tabular}{|c|c|c|}
\hline Category of Stakeholders & Institutions & Number of Participants \\
\hline 1. Local Communities & Park's surrounding Communities & 11 \\
\hline \multirow{2}{*}{ 2. Decision makers } & Rwanda Development Board & 3 \\
\hline & Local Government & 3 \\
\hline 3. Conservation NGOs & Wildlife Conservation Society & 2 \\
\hline 4. Media & Radio Rusizi & 1 \\
\hline Total & & 20 \\
\hline
\end{tabular}

The main analytic tool used to compare the level and quality of community participation with theoretical indicators and core values of the participation was the "Effective participation processes Chart" [36] which has been adapted to take into consideration the case study specificities (Figure 2). 


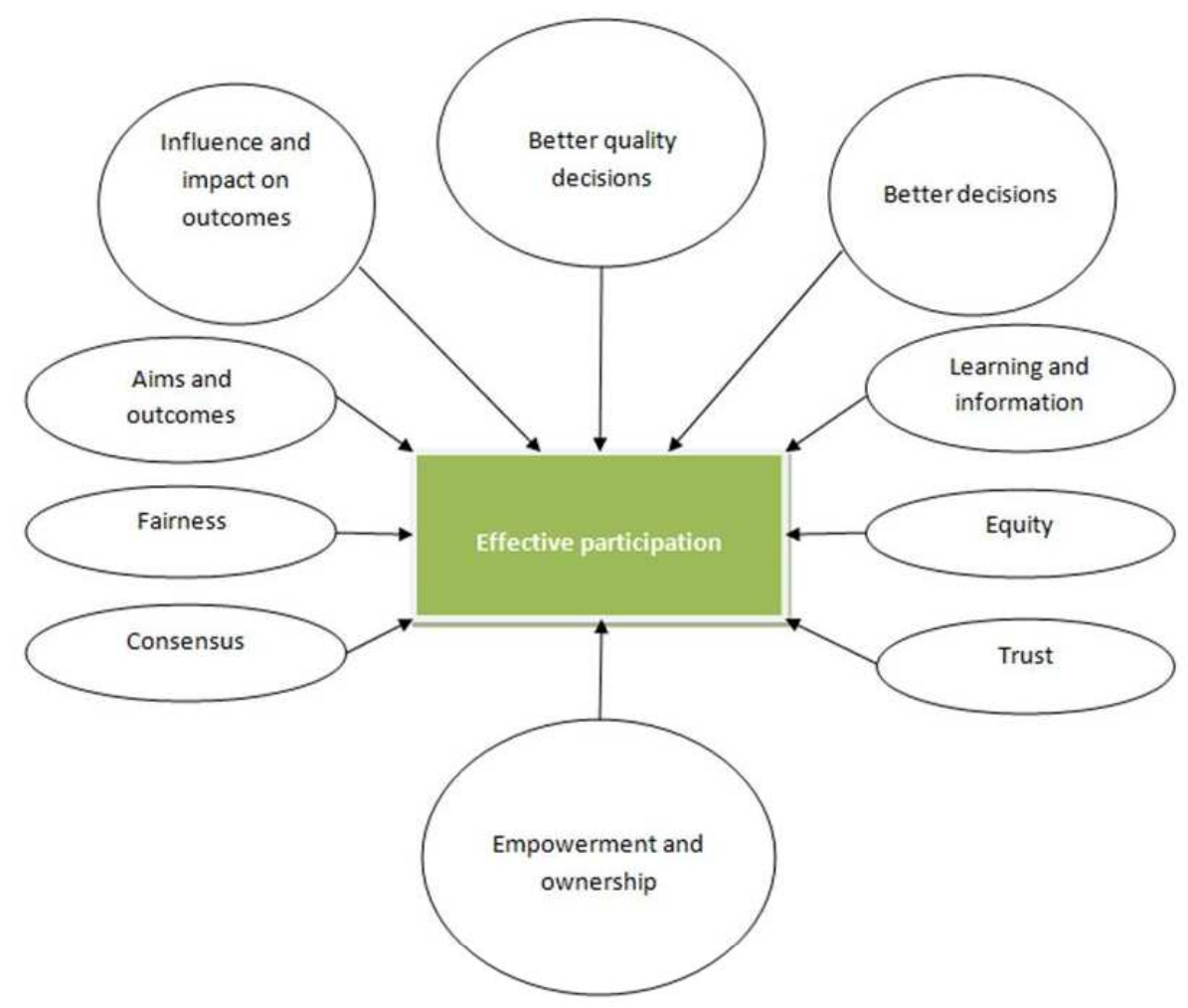

Figure 2. Effective participation processes Chart (Adapted from [36]).

The study was carried out in 3 zones bordering the NNP: (1) Kitabi Sector in Nyamagabe District, (2) Nshili zone in Nyaruguru District and (3) Rusizi headquarters in Rusizi District (Figure 1). The 3 locations were chosen purposively due to their specific needs in terms of conservation. Nshili zone is an ecologically sensitive zone of bamboo habitat predominantly. Kitabi is one of the currently most used tourism zones with activities adjacent to main intensity road crossing the park. It also includes other activities such as tea plantations, Tourism school and major towns. Rusizi District is another important stakeholder with 5 sectors and a convergence of possible tourist sources from neighboring countries, DRC and Burundi.

The data collected or the contents of interviews were transcribed, translated and analyzed using content analysis methods [33]. Deductive codes were developed from existing literature were incorporated in software MAXQDA that analyses qualitative data to make the coding process easier. Inductive codes that were coming out as new information from the data were also incorporated in the coding system.

\section{Results}

\subsection{New Managem ent System and Park-Periphery Interactions}

The comparison between the new law based management and the situation prior to the present day management showed that before the erection of Nyungwe Natural Reserve into NNP, the population entered the forest no matter how in different activities like mining, woodcutting, timber, medicine, honey collection, poaching of animals and searching lands for cultivating. These activities were not illegal because local communities considered the forest as their own heritage. The new governance mechanisms set up by the law comprises intern mechanism and extern mechanism On one hand, intern mechanisms include field staffs who are the implementers and law enforcers.

On the other hand, the extern mechanism comprises the regulators or planners and controls external actions. For example, the RDB (Kigali staff) is the one which controls regulator guidelines. One of the key meetings in the system brings together different stakeholders on the invitation of the RDB for annual assessment of the management of the park. $\mathrm{RDB}$ presents reports of the activities, challenges and problems they faced and how they addressed them; the projects funded etc. The community representatives don't have any information and don't attend the meeting because all processes are under the control of RDB.

The level of participation of local communities is still low for many reasons. The community participation remains only of procedural kind (electing local leaders at the village, cell and sector levels) and through cost-sharing i.e. local taxation 
to pay for services and communal labor sharing. More substantive participation through engaging in planning processes, community agenda prioritization and decisionmaking is all but missing.

\subsection{Understanding of the Community Particip ation}

\subsubsection{Park's Governance System and Tourism Revenue Sharing}

The NNP management structure under RDB staff authority consists of Chief Park Warden having an overall authority, 3 community conservation wardens responsible for community outreach programs. The management mechanisms consist of RDB staff in Central Office; a District Officer in charge of Environment and an Officer in charge of the environment in the Sector. At Cell and Village levels, the persons responsible for the environment are the Conservation Animators (ANICO), full time volunteers and opinion leaders within the community who provide all information about the parks.

Annually, 2 to 3 meetings enlarged to judiciary and security bodies are organized by $\mathrm{RDB}$. The annual management meeting brings together all the districts bordering the Parks to discuss the reports of management. However, one can say that the local communities are represented by district officers and executives of Sectors who may speak on their behalf. The role of the communities is a key to the success of the new management based on the prevention of illegal activities.

The strategy that has been used by $\mathrm{RDB}$ is to group and mobilize the population into associations according to their respective keen activities, then to build their capacity in elaborating and presenting projects for funding. WCS and $\mathrm{RDB}$ officers of NNP play the role of mediators between the communities and funding agencies including Savings and Credit Cooperatives (SACCO) and other funding agencies, like Microfinance Institutions such as Réseau Inter-Diocésain des Micro-Finances (RIM) of Roman Catholic (Gikongoro).

The tourism revenue sharing allocated to NNP and its surrounding Districts stakeholders has been continually increased. For example for the Rusizi district it was 38824 US\$ in 2015-2016 and 54539 US\$ in 2016-2017. In July 2018, RDB donated 10 modern housing units worth 42353 US\$ to families that had previously lived in the buffer zone of NNP to improve their livelihood.

\subsubsection{Types and Opportunities of Community Particip ation}

The mobilization and organization of the population under RDB and conservation NGO's empowerment achieved a number of goals such as: (1) community joint patrols for conservation; (2) organization of cooperatives and associations for mutual empowerment and collective responsibility; (3) revenue injection in local development and improved well-being; (4) consultative processes for development projects; (5) revolving fund and (6) Nyungwe Nziza Project. In concrete terms, the community members participate in wild fire fighting, identifying their own needs; in joint patrol program, removing traps in the park, giving information and working with researches and carrying luggage of tourists.

From the point of view of the conservationists, this community participation system helps to measure changes through the program called RBM which helps to know where traps are located and the number of traps removed in the park. RDB can then be able to know which wild animals were killed and report the incidence. Irrespective complains expressed from some individuals and development projects help to transform the well being of the community members, a boost to social transformation. At the same time, community members move to organised productions for market through cooperatives. Nyungwe Nziza project was created to strengthen sustainable eco-tourism in and around NNP.

It is benefiting the communities with employment generation which is providing economic incentives to reduce threats to the Park and conserve its rich biodiversity. Local communities find more jobs within NNP such as trails clearing and others described above. They also find market for their products such as handcraft products and money easily for their projects through the revolving fund program. The revolving fund scheme develops the community around the park and has transformed the Nyungwe forest into a highly protected National Park. Due to the abandonment of illegal activities, a chance is given to benefit from the revenue sharing scheme.

In the first instances, some families received direct non reimbursable incentives, cash, account opening; cow and other domestic donations. Many others were paid for different works like surveys they were recruited to be involved in. This scheme was completed because it could no longer continue. This study recorded that all the families of some administrative entities benefited from the early move of the new approach with the above mentioned actions undertaken in their favor. However, it is the mentality of the people of the region that needs to change. They all expect aids for free instead of working hard to use the funds available in lending institutions that work with them like SACCO and Catholic Microfinance Network (RIM).

Instead of providing aid for free, both the RDB and WCS are closely working together to connect the population to lending institutions including SACCO and Gikongoro Roman Catholic Microfinance. Different cooperatives and associations made of former Nyungwe forest users move in borrowing money from RIM.

Upon passive over the responsibility to $\mathrm{RDB}$, they now focus on empowering local communities working with the new managers of the Parks (RDB and Districts) to promote cooperative spirit and entrepreneurship among the community members. All together, 24 Sectors bordering the NNP are the targets for capacity building on how to elaborate financially sustainable projects and how to manage the loans. They negotiate with financial lenders like Gikongoro Diocese Microfinance, having abandoned the idea of working with SACCO because of their lack of experience in working with communities.

The target groups comprise beekeepers, tree cutters for 
carpentry; bamboos cutters for different handcrafts; hunters; miners; grass cutters; farmers and others. Whilst its operational costs are funded from the USA, WCS may help communities to elaborate projects that would fit in the funding from many different schemes and funding agencies including RDB.

\subsubsection{From Forest Free Use to Self-Reliance: Cooperative Associations at Cross-Road}

The study showed that the main reasons which contribute to the slowness of the smooth transfer of management are: (1) the slow change of mindset, (2) the geography of the region that unfits for farming which is the most common activity for rural Rwandans and (3) the unaffordable lending conditions of the lending agencies, to mention just a few. Reference made to the slow change of mindset, people in the region have taken for granted the life depending of the free access to the NNP resources.

Next to the period of the inauguration of the law preventing them from illicit use of the park, they were given direct aid. This cannot go on forever and people have to work hard to earn their existence. Among the privileges, we noted the presence of many NGOs that did not exist before and working for empowering communities through capacity building and access to funding. The study showed a big deal of communication and misunderstanding on the interpretation given to the tourism revenue sharing approach.

For instance, the hunters association never received any incentives in compensation of withdrawing from the forest and of associating to prevent anybody from returning to the forests. This should be the reason why poaching is still going on at a high level. Of the view of the park staff, members of the associations are hard to handle because of the receiving mentality many of the bordering community members have and the non-observance of the counseling about the management principles of cooperative associations. Once they have received money, they don't use it to address the issue the funding was provided for.

Regarding unaffordable lending conditions, reports of cooperative associations focused on how their members borrowed the money available for them in the financial lending institutions mentioned above. The cooperative associations meet different challenges with regard to the loans. Recurrent issues of concern for the members of the cooperatives include: (1) the high size of equity announced to be $10 \%$ initially and made $20 \%$ at the time of application, (2) the lack of guaranty or insufficient guaranty, (3) the unpaid loan from other lending institutions, (4) the short period of loan which was reduced to 6 months from 12 months announced at the time of the sensibilisation, (5) the high rates of interest (19\%); and (6) the joint responsibility for bad borrowers that locks up the whole group when a member of the group is insolvable.

Given the fact that most of the projects like agricultural based ones take more than 6 months to generate income, members of the associations resolved to never take the loans instead of exposing their family earnings and properties to being repossessed by the lending institutions. In addition, many members of the cooperatives don't have properties or earnings to give as guaranty for the loan. Others have no property documents which disqualify them from a financial institution loan. Some members of a cooperative may have loans from other lending institutions. In that case, fear to accumulate debt beyond their reimbursement capacity prevents them from taking a loan. Also relevant in this category, poor credit record for some members of a cooperative.

If one member of a cooperative association did not reimburse any loan they received from a financial lending institution, the chance for the whole association to obtain a loan is null. This seems to be a collective punishment, but it was explained that collective responsibility was promoted as mutual empowerment and community collective responsibility for society and the conservation. Despite this somber picture, there are some success stories.

For instance, some members of Twitezimbere cooperative took the loans and managed to pay well and to apply for more. Nine (9) out of its sixteen (16) members took a loan of 1824 SUS and reimbursed it within the 3 months they gave themselves yet they still accompany two of their colleagues who ought to pay off 45 \$US. Ten (10) out of its sixteen (16) cooperative members took a loan of 1718 \$US which they invested in farming and have completed the reimbursement.

\subsection{Challenges Facing the Tourism Revenue Sharing Approach}

The TRS approach is facing many challenges related to the insufficient of natural resources and the rising population pressure. The level and degree of community participation is channeled through the RDB management dynamics. RDB calls for proposals of projects from the community through different cooperatives and associations. Once projects are accepted they are given funds basing on the priorities. RDB is also in charge of teaching cooperatives members how to design, to execute and to manage good projects through different processes of capacity building. The RDB staff informs the community on different stages of projects elaboration and when to submit their projects for funding.

Funding typically goes mainly to those communities that pose the biggest threats to the park. The programs funded by the Tourism Revenue Sharing mechanism are about improving people's lives and to preserve biodiversity. The project implementation is enhanced through local labor and knowledge. The projects are planned by the Sectors taking into consideration the needs of the local communities. RDB informs the districts of the budget allocated to them and the districts invite their sectors to present projects which are selected at district level. In fact, being the lowest body which deals with public accounts audit, the district is the local entity to receive and manage the money to funding projects presented by Sectors.

The new management approach is welcomed and praised by many observers. According to district officers, the elaboration of projects at the Sector level is well informed of 
the community needs by those who know them better. There are lots of new initiatives including schools that were recently inaugurated in Sectors like Gisakura, Cyamudongo and Butare. The collaboration between RDB and WCS in smooth transfer of the management and in organizing radio programs they broadcast on the revenue sharing plans helps to raise the awareness of the population over the conservation and preservation of the park.

However, there are dissent voices from some members of the community. According to them, they are some concerns over a number of challenges. Firstly, through the new approach, the top-down management model is perpetuated by the dominance of the RDB in the definition, the implementation, the monitoring and the evaluation of policies. Even the local government authorities are informed; not considered full entitled stakeholders.

They are informed of the budget allocated to district and invited to present projects for funding, and then supervise the elaboration and the implementation of funded projects. Secondly, the fact that the funding supports the projects planned by the districts including housing, education, health and infrastructures, management projects help the district to perform well in Imihigo (District performance contracts) instead of benefiting directly to individual families. Given the fact that local families and community members do not receive direct incentives in compensation to their withdrawal from the Park, they ask what difference the new system does have compared to the districts where the population does not depend on the forest.

After all, the government, in its mandate, is financing similar projects in other districts. Thirdly, the community members are almost absent in the monitoring and evaluation of the processes. In the annual management meeting, not only the population is not represented, but also the district is not well informed of who the RDB invites in the meeting and on which basis.

\subsection{Challenges Facing the Conservation Programs}

Since the implementation of the new management approach, poaching for meat and money remains the main illegal activity that NNP is facing now at a high level. Mining is no longer a big issue because the rate is coming down. In various occasions poaching result from conflicts between humans and wild populations because animals go out to raid crops of the community and injure sometimes community members. These tensions pushed the government to create a compensation fund which pays for crops that are damaged on the basis of field pictures, assessment of damages by agronomists and forms for compensation. However, victims who experienced this process found it slow and complicated. Some never take the step to report to the Sector's staff and to RDB where applications are signed in order to have and take all the documents to Kigali where the Compensation Office is located.

This process is constantly denounced by the population as long, complicated, expensive and confusing for rural populations who have to report to big City like Kigali where they have not been before, spending nights and days for services that are slow to come. The consequences are many including no-cooperation of the community and increased traps that kill animals instead of conservation. Adding to that, the Tourism Revenue Share comes late for the budgeting process in district to take them into consideration. The exact amount of the allocation is communicated by midterm budget revision and yet that the amount is not transferred until the end of the fiscal year. Therefore, the allocation cannot be put in the planning and is always moved to the next fiscal year. This handicap the execution of the projects planned.

\subsection{Community Participation and Information Exchange}

Good communication upward and downward is a key to the success of sustainable conservation and preservation through community participation. The local communities are accountable for their projects. This has been a gradual change from individuals to the whole society. Individuals will be accountable for the projects conceived by themselves but through community. On the other side, the Park management staff follows up and participates in project selection and approval. The Park management provides funds for community as beneficiaries but they are responsible for monitoring the use of that money.

Persistent exchange of information and communication lead community members to contribute to the formulation of management plans, the project evaluation and the biodiversity monitoring. At the stakeholders' annual meeting, the community sends representatives who take information back to him. In other meetings the Cell or Sector staffs attend and provide information regarding the park. Media reports and programs on environment protection and conservation are part of the strategy promoted through talks on Radio Rusizi and Radio Salus. Gradually, the community understands the role of the forest and parks.

In the past people valued the forest in terms of mining activities, timber and poaching. Today, they know the role that NNP is playing in generating income for community projects. The collaboration between NNP and the community is the one way to achieve the sustainability of the community well-being and of the protection.

\section{Discussion}

As it has already been mentioned previously, the community based conservation process is slow and low. The weak performance of the new approach is due to the lack or insufficiency of fairness, consensus, learning and information, influence and impact on outcomes and aims and outcomes as indicators of effective participation [20,19, 15]. Sharing tourism benefits with local communities has always been a controversial issue whatever approaches of community participation in tourism industry are involved [37].

Although tourism can generate considerable benefits, it is facing inequitable distribution of costs, benefits and power among different actors on different scales and the 
insignificant economic impacts at local destinations. Defenders of TRS philosophy argue that it promotes tourism development and ensures that local communities enjoy tangible benefits from the industry while participating in wildlife conservation. It rings good positive impact on community attitudes towards conservation of national parks [38]. Wherever the people were considered without a voice in the development process of TRS, they threatened the sustainable tourism development and put in jeopardy the involvement and participation of the community [39].

Many ICDPs implementers are failing to meet the social and economic dynamics of the resources use in the areas and therefore the real threats to biodiversity are not recognized and not correctly addressed [9]. The great dependency on natural resources can be explained by the low agriculture income, limited access to job opportunities, food insecurity, illiteracy and large size of local families $(>6$ people per household) among other things [24]. As it appears, the RDB central and field staffs play key roles in the regulatory system and processes and in the control.

The new law seems to give no room for community association participation, independent bodies like the WCS and local governments as part of the RDB mechanisms of the Park management even if this does not meet the point of view of RDB. As [15] found it, through TRS system communities are the primary actors in conservation program. They are empowered and involved through awareness raising and education. The process of mediation played by $\mathrm{RDB}$ is subject to some questioning of members of the community and observers who consider that the community members are not included in the identification of the projects that meet their needs nor involved in the monitoring and evaluation of the park management.

The new approach is a downward driven process given the fact that NNP is a state owned and controlled park and not a co-managed protected area. This questions on the sincerity, the effectiveness and the sustainability of the community based conservation according to the criteria of such approach $[15,19,20,40]$. The TRS approach has a positive and significant impact on the reduction of illegal activities except poaching. This situation carries a risk of encouragement of park depending people to commit illegal activities given the fact that their real interests and full participation are not enough taken into account.

The delay in money transfer can be overcome with some consultation between the stakeholders because if a district delays reporting, all other districts are penalized. This is a collective punishment which can fairly be resolved by collective responsibility through both shaming and mutual assistance to the defaulting district.

\section{Conclusion}

The study showed that the recent policy of community participation in the management of NNP has brought new perspectives and hope for sustainable conservation. Many conservation NGOs have moved to work along the populations to empower them and accompany initiatives, entrepreneurship and projects that overturn their eternally depending on the natural resources of NNP. Even if we note contrasted appreciations of the strategy according to the category and the position of stakeholders, it is obvious that 13 years on from the inauguration of the new management system of the NNP, the transition process towards self-reliance of the communities bordering the park is slow.

The new philosophy of socio-economic development for the communities based on grouping them in cooperative associations and empowering them to move for borrowing money for projects funding is also slow. Still the top down management model is not significantly beyond the horizons. $\mathrm{RDB}$ is orchestrating much of the processes including the definition of the policies, the monitoring and evaluation of the revenue of tourism and the organization, the planning and the supervision of the management meetings.

Despite the increasing importance of the tourism revenue shared to the local communities, community members still believe that most of the projects presented and funded by the revenue are state and district oriented to achieving Imihigo or District performance contracts, instead of community direct empowerment and well-being improvement. Much education is needed to link the projects with the well-being and transformation of the life of local populations. Equally, an effort is needed for the local communities to be fully involved in the processes of project definitions and elaboration, project monitoring and implementation and park management meetings.

RDB should develop a clear and real community-based conservation approach that will see communities around NNP region actively participate in the decision making process of activities related to tourism and conservation. Using the theoretical criteria for effective community participation, RDB should promote an interactive participation approach where people, including local communities, local governments and $\mathrm{RDB}$ itself will collaborate and participate together in the development of action plans and structure or strengthening of local institutions.

Adding to that, RDB should develop mechanisms that empower local communities in increasing skills otherwise some of the local communities will only participate through consultations. With regard to the credits and loans given by financial lending institutions, the rate is clearly beyond the affordability of local communities and need to be fairly decreased. The duration should be increased and flexibility allowed over collective responsibility. Individuals should respond on their own instead of penalizing all members of the cooperative associations. Additionally, to allow communities members to face the lack of properties or earnings and the lack of property documents to be given as guaranties for the loan application process, RDB should initiate a guaranty fund program in the favor of those vulnerable people, using part of the available funds. 


\section{References}

[1] Adams, M. W. and Infield, M. (2003). Who is on the Gorilla's Payroll? Claims on Tourist Revenue from an Ugandan National Park. World Development 31(1): 177-190.

[2] Western, D. and Wright, R. (1994). Natural Connections; Perspectives on Community- Based Conservation. Island Press, Washington DC.

[3] Mugisha, A. (2002). Evaluation of community based conservation approaches: management of protected areas in Uganda, University of Florida, Nantonga, USA.

[4] Jones, Samantha. (2006). "A Political Ecology of Wildlife Conservation in Africa."Review of African Political Economy no. 33 (109): 483-495.

[5] Songorwa, A. N. (1999). Community-based wildlife management (CWM) in Tanzania: Are communities interested? World Development, 27 (12) 2061-2079.

[6 Holland, T. G., Peterson, G. D. \& Gonzalez, A. (2009) A cross-national analysis of how economic inequality predicts biodiversity loss. Conservation Biology, 23, 1304-1313.

[7] Hulme, D. and Murphree, M. (2001). African Wildlife and Livelihoods: The Promise and performance of Community Conservation James Currey Ltd. Oxford.

[8] Mehta, J. N., \& Heinen, J. T. (2001). Does community-based conservation shape favorable attitudes among locals? An empirical study from Nepal. Environmental management, 28(2), 165-177.

[9] Lele, S. et al., (2010). Beyond exclusion: alternative approaches to biodiversity conservation in the developing tropics. Current Opinion in Environmental Sustainability, 2(12), pp.94-100.

[10] Gbadegesin, A. and O. Ayileka. (2000). Avoiding the mistakes of the past. Toward community oriented management strategy for the proposed national Park in Abuja- Nigeria. Land use Policy 17:89-100

[11] Mabunda, M. D. (2004). Historical overview of tourism development in the KNP

[12] Kumasi, T. C., Obiri-Danso, K. \& Ephraim, J. H. (2010). Community engagement in the sustainable management of rivers: Barekese catchment, Kumasi, Ghana. Environment, development and sustainability, 12(6), 927-943

[13] Fabricius, C., Koch, E., Turner, S., \& Magome, H. (Eds.) (2013). Rights resources and rural development: Communitybased natural resource management in Southern Africa. Routledge

[14] Salafsky, N. \&Wollenberg, E. (2000) Linking livelihoods and conservation: a conceptual framework and scale for assessing the integration of human needs and biodiversity. World Development, 28, 1421-1438.

[15] Reed, M. S., Fraser, E. D. G., Dougill, A. J., 2006. An adaptive learning process for developing and applying sustainability indicators with local communities. Ecological Economics 59, 406-418

[16] Estrella, M., Gaventa, J., 2000. Who counts reality? Participatory Monitoring and Evaluation: a literature review.
IDS Working Paper 70, Institute of Development Studies, Brighton.

[17] Reed, M. S., Dougill, A. J., Taylor, M. J., 2007. Integrating local and scientific knowledge for adaptation to land degradation: Kalahari rangeland management options. Land Degradation and Development 18, 249-268.

[18] Binot A. et Joiris D. V. (2007). Règles d'accès et gestion des ressources pour les acteurs des périphéries d'aires protégées. VertigO - la revue électronique en sciences de l'environnement [En ligne], Hors-série $4 \mid$ novembre 2007, mis en ligne le 11 novembre 2007, consulté le 21 avril 2016. URL: http://vertigo.revues.org/759; DOI: $10.4000 /$ vertigo. 759

[19] Binot A. (2010). La Conservation de la Nature en Afrique Centrale. Entre Théories et Pratiques. Des Espaces Protégés à Géométrie Variable. Thèse de Doctorat, Université Paris 1 Panthéon-S orb onne, 444p

[20] Laslaz L. (2010). Parcs nationaux de montagne et construction territoriale des processus participatifs. Revue de géographie alpine/Journal of Alpine Research Vol. 98, 19p.

[21] Kapoor, I., (2001). Towards participatory environmental management? J. Environ. Manag. 63, 269 et 279.

[22] UNDP, 'Turning Vision 2020 into Reality: From Recovery to Sustainable Human Development. National Human Development Report', Kigali, 2007.

[23] FAO, (2005). Negotiation and mediation techniques for natural resource management by Antonia Engel and BenediktKorf.

[24] Masozera, M. K. (2002) Socio-economic impact analysis of the conservation of the Nyungwe Forest Reserve, Rwanda. MSc thesis, University of Florida, Gainesville, USA.

[25] Munene Ndereba, I, 2017, "The movement for communityled development. Lessons from Rwanda. Retrieved from https://communityleddev. org/2017/06/27/les sons-fromdecentralization-in-rwanda/

[26] REMA, (2015) Study to establish a national list of threatened terrestrial ecosystems and species in need of protection in Rwanda. Kigali, Rwanda.

[27] ORTPN, (2005). Tourism Revemue sharing in Rwanda. KigaliRwanda.

[28] RDB, (2012). Nyungwe National Park Management Plan 2012-2021.

[29] Kurt, A. K. and R. A. Fimbel (1994). Gold mining Activities within the UGZ 4 Management Zone Nyungwe Forest Reserve, Rwanda. Nyungwe Forest Conservation Projet.

[30] REMA, (2015) Study to establish a national list of threatened terrestrial ecosystems and species in need of protection in Rwanda. Kigali, Rwanda.

[31] Mulindahabi, F. \& Ndikubwimana, I. (2010) Monitoring Threats to Biodiversity in Nyungwe National Park, Rwanda. Ranger-based Monitoring Report Year 2010. Wildlife Conservation Society Rwanda and Rwandan Development Board Tourism \& Conservation, Kigali, Rwanda.

[32] Patton, M. Q. (2002). Qualitative Research and Evaluation Methods. Thousand Oaks: Sage. 
[33] Savin-Baden, M. \& Major, C. H. (2013). Qualitative research: The essential guide to theory and practice. London \& New York: Routledge.

[34] Silverman, D. (2014). Interpreting qualitative data ( $4^{\text {th }} \mathrm{Ed}$.). Los Angeles, London, New Delhi, Singapore \& Washington DC.: SAGE.

[35] MacMillan, J. \& Schumacher, S. (2014). Research in education: Evidence-based inquiry ( $7^{\text {th }}$ Ed.). Harlow: Pearson Education Limited.

[36] Reed, M. S., 2008. Stakeholder participation for environmental management: a literature review. Biol. Conserv. 141,2417 and 2431

[37] Tosun, C. (2000). Limits to community participation in the tourism development process in developing countries, Tourism Management, vol. 21. 613-633.

[38] Archabald, K and Naughton-Treves, L. (2001). Tourism revemue-sharing around national parks in Western Uganda: early efforts to identify and reward local commmities, Environmental Conservation, 28 (2) 135-149.

[39] Havel, V. (1996). The World Bank Participation Sourcebook, the World Bank. Available: http://www.worldbank. org/wbi/sourceb ook.

[40] Borrini-Feyerabend G., Dudley N., Jaeger T. and al. (2013). Governance of Protected Areas: From understanding to action. Best Practice Protected Area Guidelines, Series 20, Gland, Switzerland: IUCN, xvi, 124p. 


\title{
APPENDIX B: Paper 2
}

International Journal of Environment and Climate Change
$\begin{aligned} & 9(2): 77-87,2019 ; \text { Article no.IJECC.2019.006 } \\ & \text { ISSN: } 2581-8627 \\ & (\text { Past name: British Journal of Environment \& Climate Change, Past ISSN: 2231-4784) }\end{aligned}$
Environmental Justice and Women Empowerment in
Nyungwe National Park (Rwanda): Case Study of
Kitabi Women Handcrafts Cooperative

\author{
Gloriose Umuziranenge ${ }^{1 *}$ \\ ${ }^{1}$ Department of Natural Resources and Environment Management, Protestant Institute of Arts and \\ Social Science, Huye, Rwanda.
}

Author's contribution

The sole author designed, analysed, interpreted and prepared the manuscript.

Article Information

DOI: $10.9734 /$ IJECC/2019/v9i230098

Editor(s).

(1) Dr. Anthony R. Lupo, Professor, Department of Soil, Environmental, and Atmospheric Science, University of Missouri, Columbia, USA.

(2) Dr. Sarfraz Hashim, Assistant Professor, Department of Agricultural Engineering, Muhammad Nawaz Shareef University of

(3) Dr. Wen-Cheng Liu, Professor, Dept. of Civil and Disaster Prevention Engineering, National United University, Taiwan.

Reviewers:

(1) Nyong Princely Awazi, University of Dschang, Cameroon. (2) Borislav Kolaric, University Union - Nikola Tesla, Serbia. (3) Vartika Singh, Amity University, India. Complete Peer review History: http://mww. sdiarticle3.com/review-history/48394

Original Research Article

Received 18 January 2019

Accepted 10 April 2019

Published 19 April 2019

\begin{abstract}
In the framework of the community participation in conservation in Rwanda, a women handcraft cooperative was established in 2011 in the surrounding of Nyungwe National Park in Kitabi sector and Nyamagabe District. It aimed to empower economically and socially wives of former hunters who were them selves relying on natural resources and involved in harvesting different resources in park for making handcraft products. The empowerment was intended to reduce the reliance to natural resources and to contribute to the protection of the park. The objective of the study was to investigate and examine women's experiences about their empowerment through environmental justice, in terms of distributive and procedural justice and challenges faced by women. In doing so, participants were purposively selected in women handicraft cooperative and in administration bodies. With regards to data collection and analysis, semi-structured interviews and content analysis were used. The findings showed that women are socially and economically empowered. In terms of economic empowerment, access to financial loans, savings, employment and income generating projects are the major indicators of the empowerment. Improved capacity building and family relations are major concerns of social handcraft cooperative members. Regarding the participation of women in decision-making process, the findings are controversial. However, it is
\end{abstract}

${ }^{*}$ Corresponding author: E-mail: u.gloriose@gmail.com; 
still limited because of the dominance of top-down approach that does not consider enough women's voices and suggestions in decision making. Cooperative women members perceive and consider the process of communication and decision-making as passive because they are almost absent in the monitoring and evaluation processes. The participation of the community members including women only appears through meetings with or without elected representatives. The process of women empowerment is still limited by some challenges such as crop raiding, complicated and slow compensation process, high interest rate and slow process of loan and inadequate communication. The partnership approach is then recommended so as to consider women's needs and voices in the implementation of natural resources conservation policies.

Keywords: Nyungwe National Park; women handcraft cooperative; environmental justice; women empowerment; Rwanda.

\section{INTRODUCTION}

Worldwide, protected areas are recognized as important to host the biodiversity considered as living and economic resource. In this regard, their management is likely to face conflicts between policy makers, technical administration and surrounding communities. In Africa, protected areas are delimited and placed under state control with highly monitored human impact. In most of protected areas, local people are excluded from the use of natural resources and customary rights are ignored [1] to achieve natural resources conservation goals, on the basis of the perceptions that local communities are ignorant and destructors of environment. However, over the last 25 years, the image of the conservation has shifted from wildlife protection to people-centred conservation. The new approach came up with the concept of environmental justice $[2,3]$ that seeks for better conservation outcomes by involving all people and treating them fairly in all activities regarding the environment [4]. The concept of environmental justice deals with the inequities perceived and experienced by diverse stakeholders as they are subjected to activities that affect their lived environments. This is very relevant especially when certain communities are subject to inequities in the distribution and consumption of environmental 'ills' and 'benefits' [5] like in Rwanda, specifically for communities surrounding national parks who are the poorest [6-8]. Environmental injustice occurs from human activities that harm the nature and in other forms such as gender and class discrimination [9]. This is the reason why the present study is focused on women's experiences and empowerment as a key social category through environmental justice.

In the context of improving natural resources conservation policies and practices, people living in the adjacent to protected areas have to abandon some of the activities which had been long their source of income. In return, the former income has to be compensated by conservation revenue sharing through social and economic empowerment, especially in Rwanda, where protected areas based tourism is among the top priorities in political debates whereby it has become the first sector contributing to the GDP for $12.7 \%$ [10]. The decentralization policy adopted in Rwanda since 1998 and the new approach of reconciling environment and community needs through eco-tourism and tourism revenue sharing have considerably improved the community participation [11]. The contribution from income generated in tourism activities has increased from 5 to $10 \%$ of the total gross revenue earned in national parks to assist local communities based projects in socioeconomic development. The studies on the impact of tourism revenue sharing on social and economic development of local communities indicated that tourism revenues contribute to socio-economic development in different ways $[12,13]$. However, other empirical studies indicated that community based projects are failing to achieve their goals because of insufficiency of revenues, top-down governance system, lack of business skills and conflicting stakeholder interests [14-20]. Due to the controversial results, the implementation of the aforesaid strategy might therefore be an issue of very large and inclusive debate.

Beside quantitative studies, lived experiences of local communities in regard to their participation in the implementation of the community conservation policy are missing in scientific researches in Rwanda. For participation to be effective, local communities have to be empowered in term of knowledge, income and trust just to name few. Community participation can be manipulative, passive, consultation, material incentives, functional and interactive [21]. Though no form can fit all contexts, interactive participation might be important [15]. In principle, empowerment can be considered as 
mean of enabling a social environment in which one can make decisions and make choices either individually or collectively for social transformation by acquiring skills, knowledge, power and experience [22]. There two important dimensions of empowerment are: (1) the creation of conductive environment enabling responsible individual and (2) collective decision-making. The approaches of community participation that are likewise relevant for natural resources management are: (1) top-down, (2) bottom-up and (3) partnership approaches [15,23]. Currently, the partnership approach is proposed so as to mitigate the limitations of the previously mentioned other approaches. So far as women empowerment is concerned, it is the process through which traditionally underprivileged wom en are uplifted for more improved economic, social and political status [24]. In the context of nature conservation, empowering women is a key to sustainable policies and programs without compromising socio-economic development initiatives $[25,26]$. Women are expected to be independent and make decision on their own by building trust in such a way that they can empower themselves [27,28]. Women participation in decision-making is a crucial element to ensure sustainable development processes and create an influence on their norms and value [29]. In Rwanda, where women count for $51.8 \%$ of the total population mostly living in rural areas including protected areas [30], gender-oriented studies with regard to natural resources management and environmental justice are missing in scientific discourse. The study on women empowerment through environmental justice in NNP was conducted to fill this gap for three main reasons: (1) Women are materially adversely affected by environmental degradation due to disproportionately assigned caring and provisioning roles and obligations [31], (2) Women are evolving in a traditionally male dominated structure [32] and (3) Women are more likely to interact with environment in their daily basis [33-36]. Its main objective was to explore and investigate how women are empowered as a specific and key social group. The study case of Kitabi Women Handicraft Cooperative was identified since handmade products are largely contributing to wom en socio-economic development.

\section{METHODOLOGY}

\subsection{Study Area}

The Nyungwe National Park (NNP) is one of the three national parks of Rwanda. It is located in
South West of the Country. It is surrounded by 4 Districts that are Nyamasheke, Rusizi Nyaruguru and Nyamagabe as indicated in Fig. 1. NNP resulted from the erection of the former Nyungwe Natural Forest Reserve in November 21, 2005 setting up new management schemes which prevent different activities by many different groups to stop. The Park includes Cyamudongo and Gisakura Natural Forests. Until 2005, it is the Wildlife Conservation Society (WCS) that was in charge of the full management of Nyungwe Natural Reserve. The NNP is a high-altitude mountainous rainforest along the Albertine Rift covering approximately $1,019 \mathrm{~km}^{2}$. It is the largest mountainous forest remaining in Africa that is home to $20 \%$ of all African primates, including 13 primate species; 280 bird species including 25 endemic ones; 43 reptile species and 85 mammal species. The Park is also characterized by an extremely rich plant life with more than 240 species of orchids.

The NNP surrounding zones are very populated with a more or less 300 occupants $/ \mathrm{km}^{2}$. More than $90 \%$ of surrounding communities are subsistence farmers having an average cultivated area of less than 1 ha per household. Thanks to its important biodiversity, the NNP plays a big role in the surviving of the neighboring communities. It provides many ecosystemic services by means of water catchments for most of the communities and balances out soil disintegration and erosion for the surrounding communities. In terms of ecotourism, NNP is currently the second most prevalent nature based tourism fascination in Rwanda after the Volcano National Park. Guided strolls, chimpanzee following and recreational offices from Lake Kivu in this manner make the NNP special.

Since a long time tea plantations and mining activities are organized by internal villages where people were used to come for businesses and would degrade the forest [37]. Until the early 1990's, more than 3.000 people were permanently living in the park and had built houses and shops in places like Pindura and Karamba [38]. The main challenges that NNP is facing are: (1) the increased population pressure, (2) a high rate of poverty of the surrounding populations, (3) a high reliance on natural resources, especially on agriculture for livelihoods, (4) important forest and bush fires, (5) hunting pressures on largest mammals, (6) artisanal and industrial mining and (7) deforestation for firewood, medicine, grass for cattle and construction materials $[6,37]$. 
Around 360,000 people specifically fringe the recreation center. The main human threats to biodiversity include poaching, deforestation, bush fires, honey collection and mining activities [39]. These threats resulted in the disappearance of large mammals like elephants (Loxodonta africana) and buffalos (Syncerus caffer). The high percentage of poor and low educated people living around NNP is a big challenge for both tourism and conservation development [6].

\subsection{Kitabi Women Handcraft Cooperative}

Kitabi Women Handcraft Cooperative started in 2011 with 30 active members including 28 females and 2 males. The cooperative operates its activities in the surroundings of NNP in Kitabi sector and Nyamagabe District. It is basically composed of women whose husbands had been involved in harvesting different resources in NNP for making handcraft products especially before Nyungwe was recognized as National Park in 2005. Additionally, women themselves used to rely on natural resources found in the park. The cooperative was then established to reduce the reliance to natural resources rather create other sources of income for their survival and development. Its mission is to protect NNP through raising environment awareness among community members. In addition to making handcraft products for increasing their income, cooperative members initiate and undertake different activities to protect NNP such as building public latrines, sensitization and mobilization of local community about the importance of the park to their welfare as well as country development.

\subsection{Research Approach, Method and Tool}

The general objective of the study was to investigate and examine women's experiences about their empowerment through environmental justice in NNP. In the study, the concept refers to the process by which environmental actors, local communities and women are interacting and working together by identifying needs, shared values and challenges and setting up measures and goals to address them as well as implementing together activities and projects that affect their lived environment [40]. It is envisaged as a process of dealing with all justice related issues in environmental management

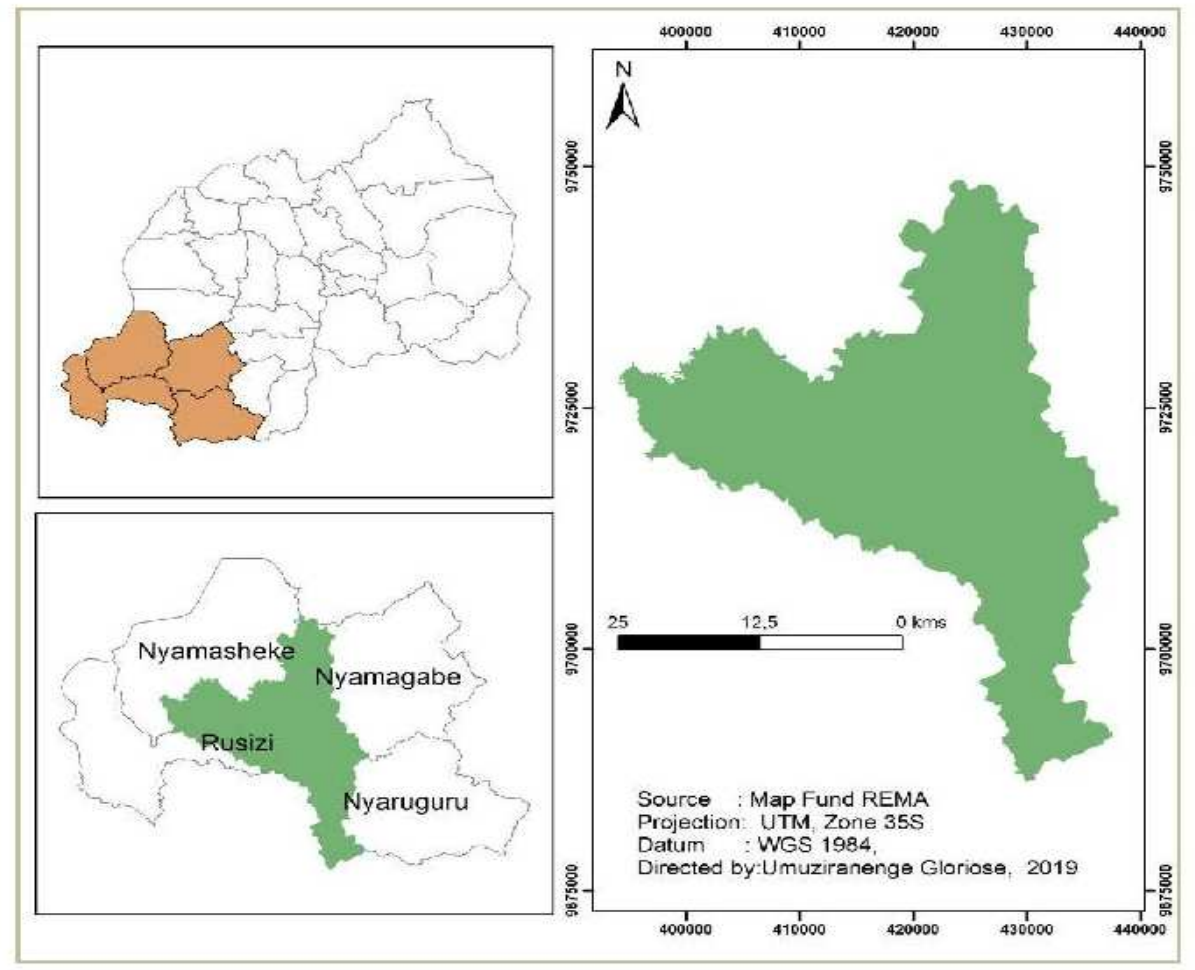

Fig. 1. Localization map of Nyungwe National Park 


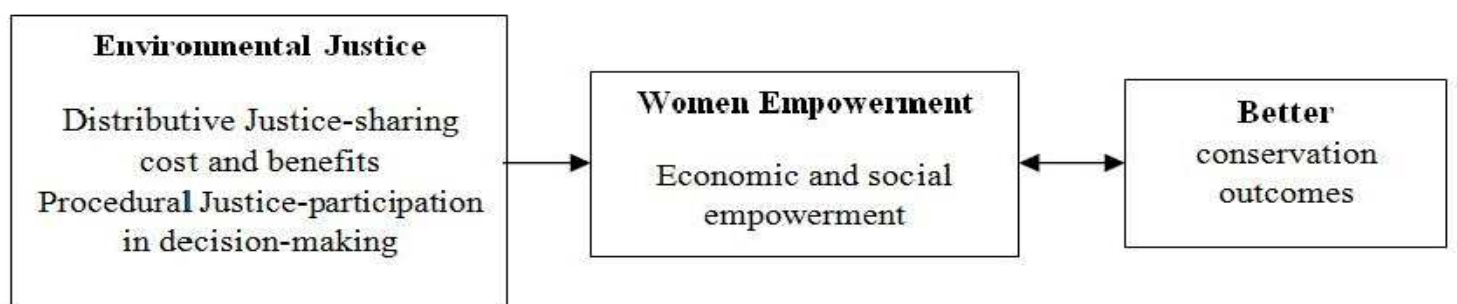

Fig. 2. Relationship between Environmental justice, women empowerment and conservation [Source: Adapted from [21] and [45]]

through distributive and procedural dimensions [41] with regard to community empowerment that are closely interlinked. Distributive dimension is concerned with equity as regard to dealing with people's outcomes in social exchanges [42]. It concerns mainly equity in the distribution of cost and benefits from natural resources management [43] among communities while procedural justice concerns decision-making procedures and processes $[44,45]$. As women's empowerment is concerned, the study seeks to: (1) explore and analyze how distributive justice contributes to women's empowerment in Kitabi Women Handcraft Cooperative and (2) explore and analyze how procedural justice contributes to women's empowerment in Kitabi Women Handcraft Association. In order to explore how individuals interpret their experiences and views, qualitative approach best fits the purpose of the study $[46,47]$. The following model describing the relationship between environmental justice, population empowerment and conservation outcomes was used to analyze and assess the women's empowerment through environmental justice in NNP management (Fig. 2).

Table 1. Category and distribution of the participants to interviews

\begin{tabular}{ll}
\hline Category of respondents & $\begin{array}{l}\text { Number of } \\
\text { respondents }\end{array}$ \\
\hline Women Handcraft & $\mathbf{8}$ \\
Cooperative & \\
RDB Staff & 2 \\
Local Administration & 2 \\
Total & 12 \\
\hline
\end{tabular}

With regard to sampling, theoretical and purposive samplings were used to progressively select participants from Women Handcraft Cooperative and decision-making bodies that are Local Administration and Rwanda Development Board (RDB). Participants were progressively identified purposively during data collection that is concomitant with data analysis $[46,48,47]$ During data collection through women individual interviews, the saturation point was reached at the eighth interview. The repartition of the respondents is indicated in the following table.

Collected data were analyzed under three themes namely distributive and procedural justice and challenges faced by women in regard to their empowerment in natural resources management. For data collection, semistructured interviews were used to gather individual experiences with regard to women empowerment. Semi-structured interviews are a viable means of learning about peoples' views especially due to flexibility and openness during data collection process $[49,50]$. The collected information was then analyzed using content analysis by identifying deductive codes derived from existing literature and supplemented with inductive categories that emerged from collected data

\section{FINDINGS}

\subsection{Environmental Distributive Justice and Women Empowerment}

The study showed that women are socially and economically empowered. With regard to economic empowerment, access to financial loans, employment and income generating projects are the major indicators of the empowerment. Improved family relations and capacity building are major concerns of social women empowerment. With the support of donors, RDB facilitated the cooperative through income from tourism to purchase sewing machines for weaving and to connect them to financial lending institutions like Savings and Credit Cooperatives (SACCO) and InterDiocesan Micro-Finance Network (RIM) of Gikongoro Roman Catholic for easy access to loans. Additionally to loans offered to cooperative 
so as to enhance handcraft business, individual members have access to the same kind of loan through cooperative which later contributes to their income generating activities. The loans contacted through the cooperative allowed members to start different projects including small agricultural projects, livestock and small trading businesses. Other income generating projects which include tailoring, knitting uniform sweaters for surrounding schools, shopping bags and small farming projects like pigs and goats raising were also developed. More on that, cooperative members were trained and started projects of knitting bags, sweaters and baskets which replaced baskets made before from traditional materials collected in the park (Figs. 3 , $4,5)$.

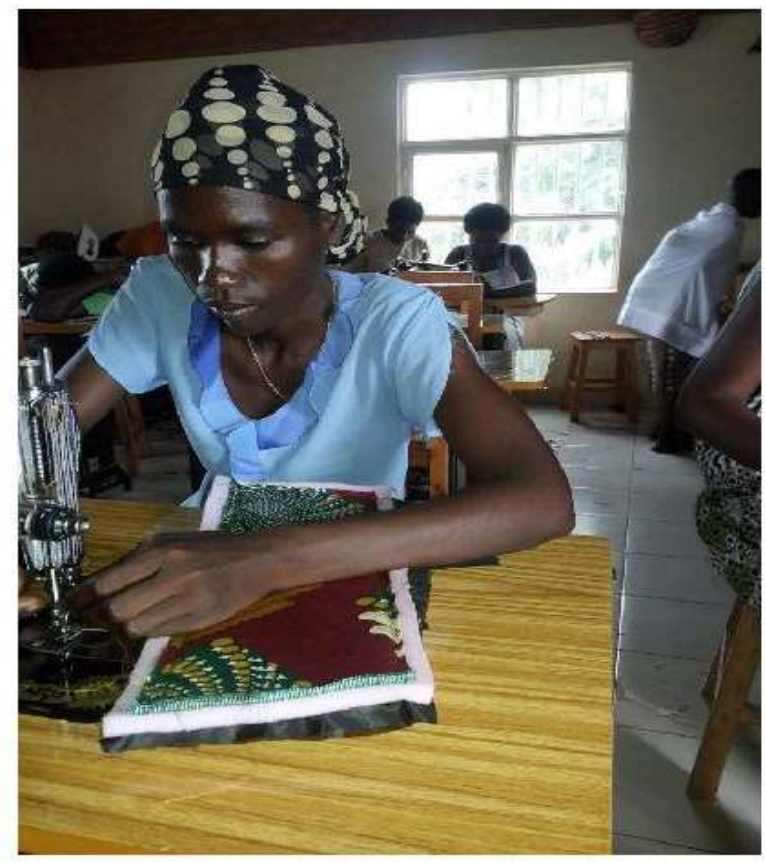

Fig. 3. Sowing activities in Kitabi Women Handcraft Cooperative

They constructed public toilets as a way of protecting the park and built Mushabarara Center which host tourists and other travelers in traditional houses. Furthermore, access to loan has created opportunities of jobs. Having been trained to making handcraft and given loan boosted the access to employment. Members of Kitabi women handcraft cooperative are regularly workers for handcraft businesses and get paid for it. Handcraft products are sold to tourists and the community members and benefits shared on an annual basis. More on that, children initiated traditional dancing clubs that entertain tourists especially during school holidays.

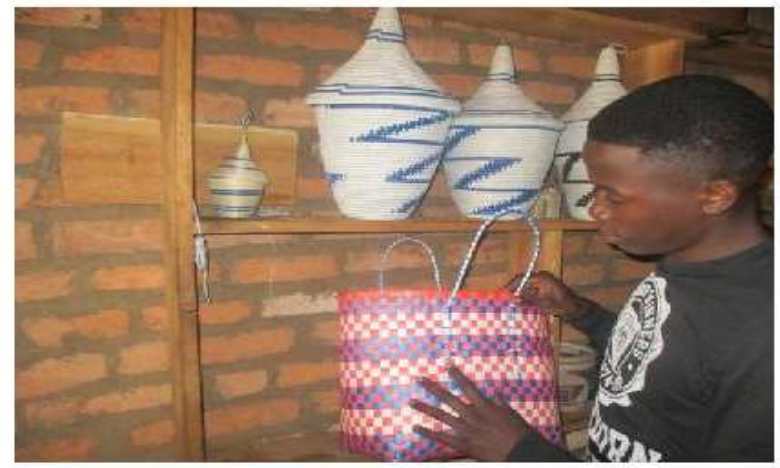

Fig. 4. Baskets and Hand bags produced in Kitabi Women Handcraft Cooperative

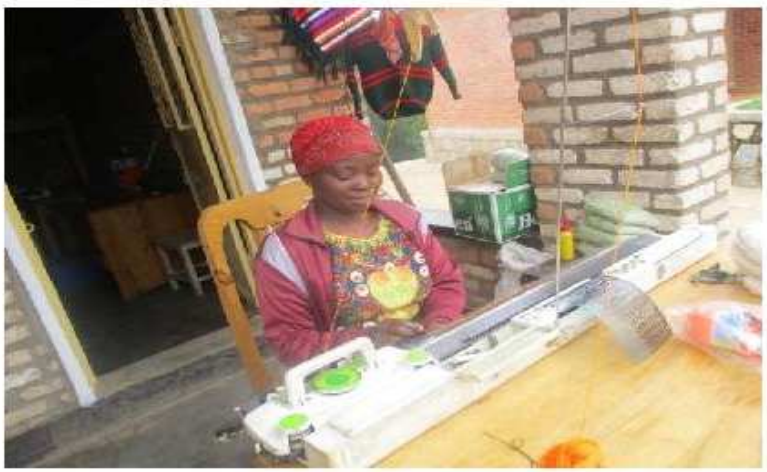

Fig. 5. Weaving machine used in Kitabi Women Handcraft Cooperative

Findings also showed that handcraft cooperative members are socially empowered through capacity building that leads to improve welfare. Among other trainings, they have been trained on handcraft making, project planning and management, environmental conservation, family planning and gender-based violence. Handcraft products are sold to tourists. The question might be about the benefits of social and economic empowerment of women in Kitabi Women Handcraft Cooperative. In terms of impact of social and economic empowerment, women's lives have improved thanks to taking part in cooperative. Women have now formal jobs and the cooperative has become their main employment and source of income as they are struggling to maintain small and inconsistent sources of income sometimes through illegal practices in the park. This is confirmed by local 
government officers and RDB staff members who said that, economically, cooperative members had not the capacity of having shelter, cattle or an account in Umurenge SACCO microfinance before joining the cooperative. Today, the socioeconomic situation of the cooperative members was improved because they are able to get money for food, for medical insurance payment and for education fees for kids through selling handicrafts materials to tourists and tourism revenue sharing program. They can afford now health insurance and small animals such as pigs and goats from the associations' benefits. Moreover, this led to satisfaction of other human needs like self-esteem. More on that, cooperative women members have become agents of change in the process of increasing awareness about environmental protection for their family members and the community as well thanks to encouragement not to hunt and other prohibited activities in NNP.

\subsection{Environmental Procedural Justice and Women Empowerment}

With regard to the participation of women in decision-making process, the findings are controversial. On one hand, $50 \%$ of women participants are not happy with their participation because leaders are the ones who decide what to do and come to population for action especially the one working in cooperatives. They also complain about their suggestions that are never considered in deciding. This was the case about their proposal of protecting animals coming out of the park to raid crops thanks to particular ways to bring them back into the park was not accepted and encouraged. Moreover, their request for mobile phones for easy communication and information dissemination was not welcomed. Cooperative women members perceive and consider the process of communication and decision-making as passive because their voices and points of view are missing in the process. Collaboration of stakeholders in regard to conservation might be problematic. Community members are almost absent in the monitoring and evaluation processes. For example, women are missing in some strategic meetings and local government administration entities are not well informed of who the RDB invites in the meeting and on which basis. Moreover, the management of finance related to tourism revenue sharing is not transparently clear to all stakeholders. What they receive and how it has to be managed rest in the secret hands of decision-makers. There is a limited participation of the members of the community which participate through meetings with or without elected representatives. Sometimes cooperative members are invited to share information with RDB and report monthly to RDB. Whenever needed they have meetings for deciding on which activities have to be done and revising measures of protecting the park as well as wild animals which come out of the park and damage or destroy crops belonging to local communities.

\subsection{Women's Challenges Concerning Empowerment}

Despite the benefits from NNP, there are some challenges that need to be reflected to enhance environmental justice as means of women empowerment. The findings indicated that crop raiding by chimpanzees and other wild animals, complicated and slow compensation process, high interest rate on loan, slow process of loan, mindset of local community, lack of communication facilities and lack of study trips are key challenges for the sustainability of environmental justice and then limits the process of women empowerment. In addition, the fairness in calculations of money to be reimbursed is critical because there are not yet established commonly shared criteria and standards in evaluating crop damages. Though women handcraft cooperative members acknowledge the access to loan and close collaboration with microfinance such as SACCOs, they still face the challenge of a high interest rate and short period of reimbursement compared to other financial lending institutions. Loans that are offered by aforesaid microfinance charge a higher interest rate $(19 \%)$ compared to average interest rate of $17 \%$ in other financial institutions. Moreover, the process of approving loan takes longer. Communication between members of the cooperative and decision makers was rated to be problematic. On one hand, members of the cooperative accuse decision makers not to value their requests of providing communication facilities. On the other hand, decision makers accuse them to poorly communicate by not sharing information on time. There are also some members of the community that are still reluctant to change as regard to environmental protection as long as they still wish to continue earning their lives from NNP.

\section{DISCUSSION}

The findings are discussed in light of environmental justice criteria as developed by 
many authors $[21,15,23,45]$. Firstly, the study showed that women in Kitabi handcraft cooperative are socially and economically empowered through capacity building, access to loan and employment. They had opportunities to improve their household status (Figs. 3, 4, 5). Among others, women started income generating activities, improved family relations which lead to support RDB in the process of sensitization and mobilization of local communities about the role of the park and its conservation. This sort of empowerment led to the satisfaction of cooperative members with regards to employment, health insurance, food security and environmental raising awareness. This result confirms the fact that women are so influential in the process of change [36,32]. It also states that engaging sustainable development initiatives without involving them is an empty gesture [33]. Therefore, empowering women in NNP is likely to achieve better conservation outcomes. Furthermore, findings corroborated the point of view whereby increasing women participation and empowering them, lead to better conservation outcomes as they have privileged knowledge and experience of working closely with the environment. In this orientation, once women are economically empowered, there is high probability that natural resources will be safeguarded. These findings are in the same line of [5] who argued that as countries, especially developing ones, seek to increase revenues from tourism, communities living closer to tourist attractions, specifically those surrounding national parks had to abandon some of the activities that had been long their source of consumption and income. Therefore, environmental distributive justice is a key to sustainable conservation of natural resources. Despite recognition of economic empowerment, women participation in decision -making is very limited. In view of the model of community participation as developed by [21], it can be revealed that women participation in decisionmaking process is passive because they are receiving reports and information on the decisions without their input since their ideas are most of the time ignored. With passive participation, relationship between community members and decision makers is quite asymmetric because community members play the only role of receiving information which might be or not relevant to their needs. Moreover, the findings are in line with the top-down approach whose assumptions are to consider communities as passive in the process of decision-making [23]. Though the study showed promising economic benefits for women, the sustainability of the change in regard to their development and natural resources conservation is questionable if they do not own the initiatives undertaken by decision-makers. Indeed, the sustainability is a result of close collaboration between stakeholders in planning and making decisions for sustainable conservation and benefit sharing for development process [15].

This finding is in line with [21] model of community passive participation. The findings revealed that a little partnership and bottom-up approaches are used where the local leaders and the community sometimes meet for deciding on different activities like payment for damaged crops and punishment for people who violate law governing the park. This finding is in line with the idea of [15] and [23] according to which the government and the community work together in planning and making some decisions for better and sustainable conservation and benefit sharing for development process. Participatory process in decision making is a tool that promote trust between local community and decision makers $[21,15,23,51]$ and reach to better conservation outcomes as well as promote the success of rural development goals $[26,25]$ when there is an emphasis on the importance of local capacity building, knowledge ownership, and empowerment [52]. The challenges directly or indirectly related to the implementation of decentralization policies whereby the voices of local communities are to be recognized. Additionally, they might be reflected in relation to management approach used especially in involving local communities in NNP management.

\section{CONCLUSION}

The aim of the study was to investigate women's experience about their empowerment through the components of environmental justice. It showed that environmental distribute justice leads to social and economic empowerment of women living close to NNP. However, the sustainability of this empowerment is limited by the passive and top-down approaches dominating the implementation of policies regarding the conservation of natural resources. Based on research findings, it is suggested that RDB in collaboration with local governments should emphasize the partnership approach in empowering the communities especially women, hear their voices and build trust among the entire community members. RDB should organize more 
trainings and study trips for women in cooperatives in order to learn from others who have the same mission of making handcrafts while protecting natural resources. Regular meetings and consultations have to be organized as one way of gathering more information on time and encourage positive endeavors to protect and safeguard NNP. Moreover, sensitization has to be used as a continuous tool to change the mindset of resisting people and to show them different alternatives to the park destruction. In this regard, RDB in collaboration with financial institutions should ease the process of getting loan by reducing interest rate for community-based cooperatives. Similar studies should be extended to other community-based cooperatives operating in NNP. This is very compelling because it allows achieving at least three intertwined variants of Sustainable Development Goals (SDGs), namely gender empowerment, poverty reduction and environmental protection. There is a real need for being offered opportunities of study trips to learn from others' experiences. A partnership approach needs to be reinforced as a tool to sustainable conservation outcomes.

\section{COMPETING INTERESTS}

Author has declared that no competing interests exist.

\section{REFERENCES}

1. Jones S. A political ecology of wildlife conservation in Africa. Review of African Political Economy. 2006;33(109):483-495.

2. Di Chiro G. Environmental justice from the grassroots: Reflections on history, gender and expertise. In The Struggle for Ecological Democracy: Environmental Justice Movements in the United States. Ed. D. Faber. New York: Guilford Press. 1998;104-136.

3. Schroeder R, Martin KS, Wilson B, Sen D. Third world environmental justice. Society and Natural Resources. 2008;21(7):547555.

4. Leciejewski M, Perkins HA. Environmental justice in Appalachia: Procedural inequities in the mine permitting process in Southeast Ohio. Environmental Justice. 2015;8(4):111-116.

5. Banerjee D. Toward an integrative framework for environmental justice research: A synthesis and extension of the literature. Society and Natural Resources. 2014;27(8):805-819.

6. Masozera MK. Socioeconomic impact analysis of the conservation of the Nyungwe forest reserve, Rwanda. Doctoral Dissertation, University of Gainesville, Florida; 2002.

7. Plumptre AJ, Kayitare A, Rainer H, Gray M, Munanura I, Barakabuye N, Namara A. The socio-economic status of people living near protected areas in the Central Albertine Rift. Wildlife Conservation Society (WCS), New York. 2004;10.

8. Scherl LM. Can protected areas contribute to poverty reduction?: Opportunities and limitations. IUCN, Gland, Switzerland and Cambridge, UK; 2004.

9. Beretta I. Some highlights on the concept of environmental justice and its use. ecadernos CES 17; 2012.

10. Rwanda Development Board (RDB). Annual Report. Kigali, Rwanda; 2017.

11. Chemouni B. Explaining the design of the Rwandan decentralization: Elite vulnerability and the territorial repartition of power. Journal of Eastern African Studies. 2014;8(2):246-262.

12. Tusabe R, Habyalimana S. From poachers to park wardens: Revenue sharing scheme as an incentive for environment protection in Rwanda. In Mountain Forum Bulletin. 2010;10(1):91-93.

13. Kamuzinzi PK, Shukla J, Ndabaga E. The effectiveness of Rwanda Development Board tourism revenue sharing program towards local community socio-economic development: A case study of Nyungwe National Park. European Journal of Hospitality and Tourism Research. 2015;3(2):47-63.

14. Archabald K, Naughton-Treves L. Tourism revenue-sharing around national parks in Western Uganda: Early efforts to identify and reward local communities. Environmental Conservation. 2001;28(2): 135-149.

15. Reddy GN. Empowering communities through participatory methods. Delhi: Manak Publications; 2002.

16. Tosun C. Limits to community participation in the tourism development process in developing countries. Tourism Management. 2000;21(6):613-633.

17. Briedenhann J, Wickens E. Tourism routes as a tool for the economic development of rural areas-vibrant hope or impossible 
dream? Tourism Management. 2004;25(1): 71-79.

18. Dixey L. The unsustainability of community tourism donor projects: Lessons from Zambia. Responsible Tourism: Critical Issues for Conservation and Development. 2008;323-341.

19. Munanura IE, Backman KF, Hallo JC, Powell RB. Perceptions of tourism revenue sharing impacts on Volcanoes National Park, Rwanda: A sustainable livelihoods framework. Journal of Sustainable Tourism. 2016;24(12):1709-1726.

20. Munanura IE, Tumwesigye B, Sabuhoro E, Mariza D, Rugerinyange L. The quality and performance nexus of the communitybased ecotourism enterprises at Nyungwe National Park, Rwanda: A total quality management perspective. Journal of Ecotourism. 2018;17(2):160-183.

21. Pretty JN. Participatory learning for sustainable agriculture. World Development. 1995;23(8):1247-1263.

22. Hashemi S, Schuler S, Riley A. Rural credit programs and women's empowerment in Bangladesh. World Development. 1996;24(4):635-653.

23. Paudel NR. A critical account of policy implementation theories: Status and reconsideration. Nepalese Journal of Public Policy and Governance. 2009;25(2): 36-54.

24. Dandona A. Empowerment of women: $A$ conceptual framework. The International Journal of Indian Psychology. 2015;23485396.

25. Uphoff NT, Cohen JM, Goldsmith AA. Feasibility and application of rural development participation: A state-of-theart paper. New York: Cornell University; 1979.

26. Belshaw D, Chambers R. A management systems approach to rural development. Discussion Paper 161, Institute for Development Studies, University of Nairobi; 1973.

27. O'Neil T, Domingo P. The power to decide: Women, decision-making and gender equality. London: The Overseas Development Institute (ODI); 2015.

28. Willis AK. Breaking through barriers to successful empowerment. Hospital Materiel Management Quarterly. 1999; 20(4):69-80.

29. Cheryl EC, Page N. Empowerment: What is it? Journal of Extension. 1999;37:5-14.
30. NISR M. Rwanda fourth population and housing census 2012. Thematic Report on population size, structure and distribution. National Institute of Statistics of Rwanda; 2014.

31. Resurrección BP. Gender and environment from "women, environment and development" to feminist political ecology. Routledge Handbook of Gender and Environment. 2017;471:485.

32. Ferguson L, Alarcón DM. Gender and sustainable tourism: Reflections on theory and practice. Journal of Sustainable Tourism. 2015;23(3):401-416.

33. Dobson A. Justice and the environment: Conceptions of environmental sustainability and theories of distributive justice. Oxford: Clarendon Press; 1998.

34. Momsen JH. Gender and biodiversity: A new approach to linking environment and development. Geography Compass. 2007;1(2):149-162.

35. Haussmann R, Tyson LD, Bekhouche $Y$, Zahidi $S$. The global gender gap index 2012. The Global Gender Gap Report: 327; 2012.

36. Organisation for Economic Co-operation and Development (OECD). Women, Government and Policy Making in OECD Countries: Fostering Diversity for Inclusive Growth. OECD Publishing; 2014.

37. REMA. Study to establish a national list of threatened terrestrial ecosystems and species in need of protection in Rwanda. Kigali, Rwanda; 2015.

38. Kurt AK, Fimbel RA. Gold mining activities within the UGZ 4 Management Zone Nyungwe Forest Reserve, Rwanda. Nyungwe Forest Conservation Project: 1994.

39. Mulindahabi F, Ndikubwimana I. Monitoring threats to biodiversity in Nyungwe National Park, Rwanda. Rangerbased Monitoring Report Year 2010. Wildlife Conservation Society Rwanda and Rwandan Development Board Tourism \& Conservation, Kigali, Rwanda; 2010.

40. Resham L. Good governance: A viable option for social justice in India. International Journal of Arts, Humanities and Management Studies. 2015;1(4):4962.

41. Ikeme J. Equity, environmental justice and sustainability: Incomplete approaches in climate change politics. Global Environmental Change. 2003;13:195-206. 
42. Brashear G, Brooks CM, Boles JS Distributive and procedural justice in a sales force context scale development and validation. Journal of Business Research. 2002;57(1):86-93.

43. Walpole MJ, Thouless CR. Increasing the value of wildlife through non-consumptive use? Deconstructing the myths of ecotourism and community-based tourism in the tropics. Conservation Biology Series. 2005;9:122.

44. Sheppard BH, Lewicki RJ, Minton JW. Organizational justice: The search for fairness in the workplace. New York: Lexington Books; 1992.

45. Svarstad H, Sletten A, Paloniemi R, Barton D, Grieg-Gran M. Three types of environmental justice: From concepts to empirical studies of social impacts of policy instruments for conservation of biodiversity. Assessing the Role of Economic Instruments in Policy Mixes for Biodiversity Conservation and Ecosystem Services Provision, Report for the Policy mix Project, Norwegian Institute for Nature Research, Oslo: Norway; 2011.
46. Savin-Baden $\mathrm{M}$, Major $\mathrm{CH}$. Qualitative research: The essential guide to theory and practice. London and New York: Rout Ledge; 2013.

47. Silverman D. Interpreting qualitative data ( $4^{\text {th }}$ Ed.). Los Angeles, London, New Delhi, Singapore \& Washington DC.: SAGE; 2014.

48. Creswell JW. Research design: Qualitative, quantitative, mixed methods approach (4 ${ }^{\text {th }}$ Ed.). Thousand Oaks: Sage Publications; 2014.

49. Patton $M Q$. Qualitative research and evaluation methods. Thousand Oaks: Sage Publications; 2002.

50. Bryman A. Social research methods. New York: Oxford University Press Inc; 2012.

51. Hoverman S, Ross H, Chan T, Powell B. Social learning through participatory integrated catchment risk assessment in the Solomon Islands. Ecology and Society. 2011;16(2):5-8.

52. Chambers R. Participatory rural appraisal (PRA): Analysis of experience. World Development. 1994;22(9):1253-1268.

(c) 2019 Umuziranenge; This is an Open Access article distributed under the terms of the Creative Commons Attribution License (http://creativecommons.org/licenses/by/4.0), which permits unrestricted use, distribution, and reproduction in any medium, provided the original work is properly cited. 


\section{APPENDIX C: Paper 3}

ResearchGate

See discussions, stats, and author profiles for this publication at: https://www.re searchgatenet/publication/324780299

Ecotourism as Potential Conservation Incentive and its Impact on Community Development around Nyungwe National Park (NNP): Rwanda

Article · January 2017

$$
\text { CITATION }
$$

1

147

2 authors, including:

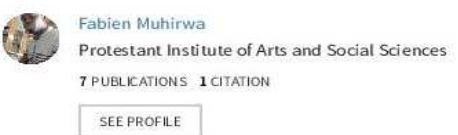

All content following this page was uplasded by Fabien Mutirwaon 26 Aprit 2018

The user has requested enhancement of the downloaded file 


\title{
Ecotourism as Potential Conservation Incentive and its Impact on Community Development around Nyungwe National Park (NNP): Rwanda
}

\author{
Gloriose UMUZIRANENGE \& Fabien MUHIRWA \\ Protestant Institute of Arts and Social Science (PIASS), Natural Resources and \\ Environmental Management Department.
}

\begin{abstract}
This study investigated the potential of revenue sharing to act as an incentive to conserve biological diversity using Nyungwe National Park $(N N P)$ and its neighboring communities, the extent of local community involvement in tourism development and conservation activities in western province of Rwanda. The study used a structured questionnaire to collect data from local residents, while face-toface interviews were conducted with key informants from Rwanda National Tourism and Conservation Agency and local government officials as means to obtain deeper insights.

The findings established that there is little active involvement of local communities in NNP. There is lack of empowerment to participate in decision making especially of community conservation outreach and tourism revenue sharing projects. The researcher believes that in the light of the research results, the decision making system for Nyungwe National Park tourism and conservation development plans is still highly top-down approach. It has also established that higher losses result from wildlife crop raiding as compared to benefits derived from conservation. There are some problems that people cause to NNP, the main problem is tree cutting, burning forest and hunting wild animals. People around NNP use woods, medicines, and honey as resources. It has established that tourism revenue sharing and related benefits could serve as an incentive for conserving NNP and concluded that if tourism is well managed, it can act as an incentive for conservation through stopping illegal activities. The study recommends that local communities around Nyungwe National Park should be Consulted and involved in development programmes within their villages from the start and this will ensure their participation in conservation activities.
\end{abstract}

Key words: Eco-tourism; Economic incentives; Revenue sharing; Wildlife cost and benefits; Empowerment

\section{Introduction}

\subsection{Tourism industry}

Tourism industry represents one of the main sectors in the global economy, often referred to as the world's largest single industry (UNEP, 2005). Tourism development and biodiversity are intrinsically linked (UNEP, 2005). Nature-based tourism, including ecotourism, adventure and wilderness travel is a large and growing global industry (Hiwasaki 2003).

The areas that are particularly appealing to ecotourists are often places with high biodiversity (Honey, 1999). Tourism is also in a very special position to benefit local communities, economically and socially, and to raise awareness and support for conservation of the environment (UNEP, 2005). Tourism in Africa, has previously contributed greatly to national economies, but has provided limited benefits to the local populations, yet the locals have been and still the custodians of the natural resources that tourism depend on especially protected areas. Protected areas in developing countries are often viewed as a source of income from timber, oil, mineral exploitation, or tourism by the government (Putz, 1988). Rao and Geisler (1990), however, indicate that the high dependence of the population on natural resources for agricultural, energy, nutritional, medicinal, and other needs make protection and conservation of protected areas to be difficult in many places.

Conservation strategies in Africa have been characterized by exclusion of human use of resources in protected areas. In particular, this approaches, which is often described as "fortress conservation" or "the fines and fences" approach (Wells \& Brandon, 1992:11)?

Ecotourism has been proposed as a viable economic activity that can minimize negative human impacts on wildlife habitats, yet provide an incentive to preserve natural area (Isaac, 2000). This approach also attempts to decrease local people's dependence 
Imperial Journal of Interdisciplinary Research (IJIR)

Vol-3, Issue-10, 2017

ISSN: 2454-1362, http://www.onlinejournal.in

on natural resources by substituting alternative livelihood activities (Sayer, 1991). Where those mentioned natural resources are intrinsic to everyday livelihood and household budgets, even well funded coercive conservation generally fails (FAO, 2005).

In order to involve the communities in park protection and conservation and to let local community benefit from the park, the park authority, Rwanda Development Board (RDB) has introduced a revenue sharing program that consists of sharing a percentage of tourism income between the country and communities surrounding the park so that local communities who have to bear the cost of conservation also benefit from it and have a stake in its success. On the park side, this is one of the ways that can increase awareness amongst local people with the hope that they will support conservation and contribute to park protection. The revenue sharing program has been in existence for several years and ongoing sensitization and awareness raising campaigns are carried out by Park staff. However threats from the local communities towards the park and ongoing conflict still exist.

Therefore it is essential to have a better understanding of local community attitudes towards the park and conservation and to the revenue sharing program in particular (Adams and Hulme 2001 cited by Scholte, 2010). This would help improve revenue sharing to ensure that it meets community expectations but would also help community conservation teams better guide their work to have a bigger impact on improving community awareness and support and to understand the needs and expectations of the communities for this support (Adams and Hulme 2001 cited by Scholte, 2010).

\subsection{Conservation in Rwanda}

The natural resources such as forest, land, water, etc, remain central to rural people's livelihoods (FAO, 2005). While biodiversity provides the basis for economic growth, the tendency has been towards over-exploitation and degradation (Rwanyiziri, 2011). As human population increased trough time without an increase of natural resources, the ecological footprint (the amount of nature needed to support a human being) increases also (Rwanyiziri, 2011).

Conservation approaches started with "fortress conservation" that excluded the local populations from the use of natural resources (Kusters, 2009). This approach considered local people as ignorant destructors against whom nature should be protected (Wells \& Brandon, 1992:11). In the 1980's, that old conservation approach was replaced by a new conservation approaches known as "community based conservation (CBC) that include local communities in the management of natural resources. In our country, community conservation face challenges related to the insufficient of natural resources base and rising population pressure. Rwanda can be described as a country with severe demographic stress relying for subsistence on a limited resource base. About $57 \%$ of Rwandans live in abject poverty and people occupying or living in the vicinity of the world's areas richest in biodiversity are the poorest (Rwanyiziri, 2011). In $\mathrm{R}$ wanda, the level of public involvement in decision making of natural resources management is still low. This low level of participation can be explained by available resources, schedules, budgets, and staffing (Rwanyiziri, 2011). The decentralization policy allowed establishes environmental committees from the village level to district level (REMA, 2010). However, these structures are not fully operating. Officially, districts are supposed to allocate sources to this program (fund, staff and other resources) but it is noted that some districts do not have sufficient resources to allocate all programs and environmental issues are not mainstreamed in their plan and budget (REMA, 2010). Community sensitization requires fund mobilization and resources (money, facilities, etc.). However, most of time there is lack of fund for that activity (REMA, 2010).

\subsection{Ecotourism as an incentive to conservation}

Ecotourism is defined by Honey (1999), as "travel to fragile, pristine and usually protected areas that strives to be low impact and (usually) small scale. Ecotourism occurs on a smaller scale than forms of mass tourism, and is based on the conservation of nature and gaining an understanding of local cultures (Hawkins and Khan, 1998:196).

Ecotourism has generated great interest from governments, tourism enterprises, tourists, conservation groups; and other stakeholders within the industry (Hvenegaard, 1994; Lindberg \& Hawkins, 1993). It helps educate the traveler, provides funds for conservation; directly benefits the economic development and political empowerment of local communities; and fosters respect for different cultures and for human rights". One of the principles in ecotourism equation is that; "it provides financial benefits and empowerment for local people.

Since 2005, ORTPN has initiated a revenue sharing scheme whereby 5 percent of tourism revenues from the park fees are utilized to support local community projects around national parks, aiming to sensitize local people to fill that parks are as one of their own. Some of the private tour operators also offer community-based tourism activities, such as stays with a local family, village walks, banana beer 
Imperial Journal of Interdisciplinary Research (IJIR)

Vol-3, Issue-10, 2017

ISSN: 2454-1362, http://www.onlinejournal.in

production or even volunteering opportunities in local communities (ORTPN, 2004).

\subsection{Objectives}

This study aims to understand the impact of NNP revenue sharing scheme on community development around Nyungwe National Park. In other words, whether or not the sharing of tourism revenues and related benefits from tourism to NNP with local communities has served as an incentive towards conservation, and to determine the extent to which current tourism revenue sharing projects have addressed community-related problems, issues, concerns and whether communities link such benefits to conservation. The specific objectives were: (1) To determine the views of the local community towards the scheme administered by RDB to share tourism revenue and benefits with the local community; (2) To determine the views of both local community on whether economic benefits reach the local communities from tourism in NNP; (3) To determine the extent of community participation, and how RDB/ park management staff interface with local community around NNP; (4) To assess the attitudes and behavior of local population towards conservation within NNP; (5) To find out whether communities link tourism revenue sharing as an incentive for conservation; and (6) To determine if ecotourism can serve as a potential incentive for conservation in NNP.

\section{MATERIALS AND METHODS}

\subsection{Data collection}

This study used a combination of survey method and interview method to gather information. Surveys are the most common method of generating primary data as Zikmund (2000:66) explains, a survey is a research technique in which information is gathered from a sample of people by using a questionnaire. In addition, the study used an interview method to be able to obtain more insight into the research problem.

The interviews were applied to key informants from ORTPN and government official who could provide helpful information that may not be obtainable from secondary data. Questionnaires were administered to respondents from local communities. After identifying 3 administrative sectors that were adjacent to NNP, a random selection method was used in order to select respondents. In this case, it should be explained that the random technique was used because all the population units under study were considered homogeneous and, therefore, any one of them had an equal chance of being included in the sample.
Respondent from local communities selected randomly from 3 districts (Nyamagabe, Nyamasheke, Nyaruguru; Fig. 1), from each district one sector was selected randomly from 3 sectors that bordered with NNP. From each sector, 1 village was randomly selected. From each village, 30 households were selected randomly, making 90 households in total.

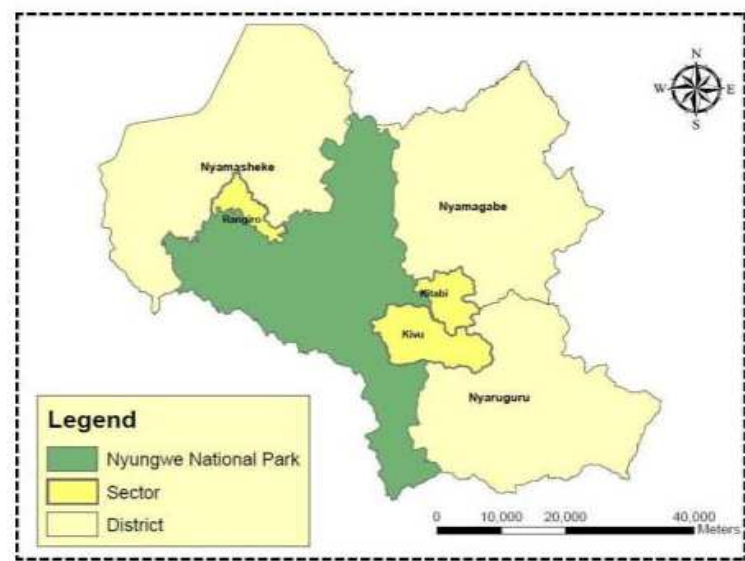

Figure 1. Map of Nyungwe Forest showing three neighboring sectors that were used for the interview

\subsection{Data analysis}

The data was transcribed onto a standard form in the field, in such a way that the data could be coded and assigned numerical values for its subsequent analysis. For example for demographic data, a variable like female was coded (1) while male was coded (2).

Responses to categorical data was also assigned numerical values and entered. Statistics was run for all questions, in order to generate statistical information using independent or grouped variables. Frequencies of different responses were expressed in percentages and graphed where appropriate.

\section{RESULTS \\ 3.1. Demographic characteristics of the respondents}

In total, $82.5 \%$ of responds were male and $17.5 \%$ female. Female were less dominant in the interviews because when they were found with their husband, they considered the answers of their husband to be sufficient. Most respondents were in the age group 25-35 in Nyaruguru and Nyamasheke, while it was 36-46 in Nyamagabe District (Fig. 2a). The results clearly indicate that respondents were matured (in age) and hence expected to have knowledge and awareness of what happens in and around their 
Imperial Journal of Interdisciplinary Research (IJIR)

Vol-3, Issue-10, 2017

ISSN: 2454-1362, http://www.onlinejournal.in

communities. More respondents had received primary education. Very few respondents had received secondary education (Fig. 2c). The study area is rural and most of community members were farmers who had stayed working on their farms rather than going to school. Moreover, many of those community members who had obtained higher educational qualifications were working in town. As a primary occupation, almost all respondents were farmers few exceptions were those respondents who were students, those who did business and Government employee (Fig. 2b). More respondents have between 3-5 children; others have between 1-3 children (Fig. 2d).

(a)

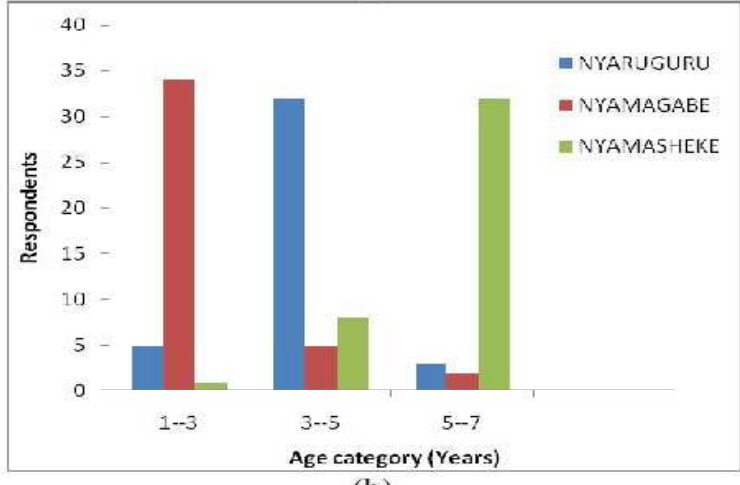

(b)

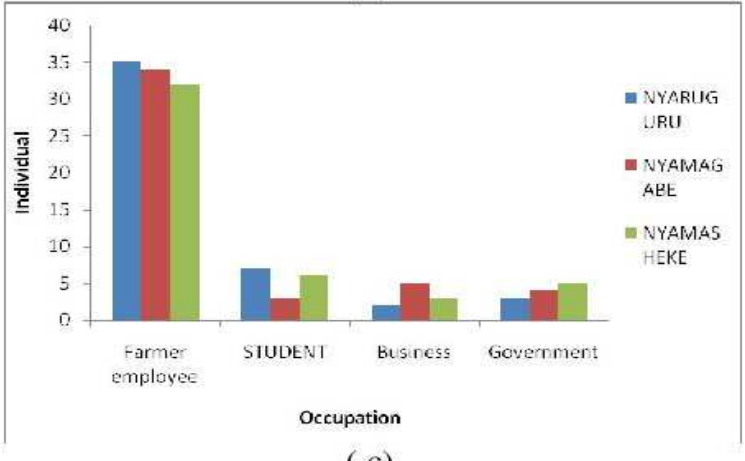

(c)

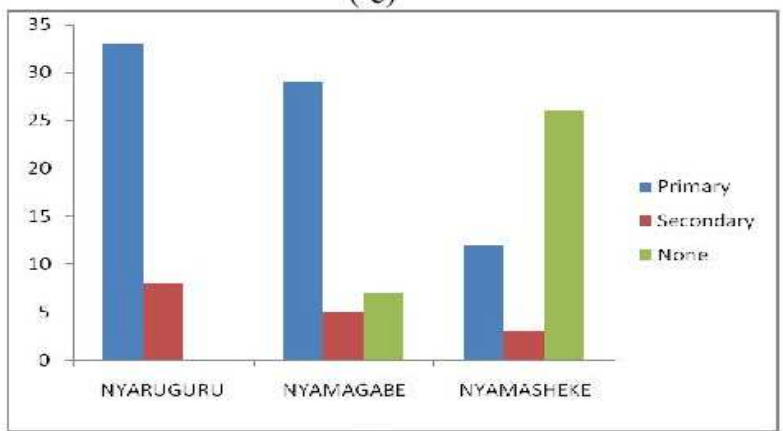

(d)

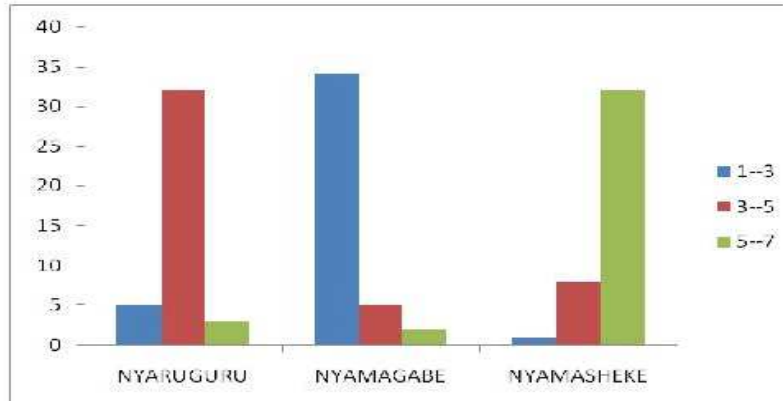

Figure 2. Age distribution (a), Occupation (b), education background (c) and number of children.

More respondents have houses with roofing by Iron sheet, very few exceptions of houses that are roofed by thatch (Fig. 3a), their houses are constructed by woods, the very few exception houses that are constructed by bricks (Fig. 3b). More respondents have health insurance and very few respondents don't have any health insurance (Fig. 3c). Access to clean water is estimated to $95 \%$ (Fig. 3d). More respondents have access to

Schools and very few respondents don't have access to school in Nyaruguru and Nyamasheke district where schools are far from their home (Fig. 3e). Farming is the main economic activity with $91.7 \%$, and very few respondents are looking after cattle and women are doing handcraft activities (Fig. 3f).

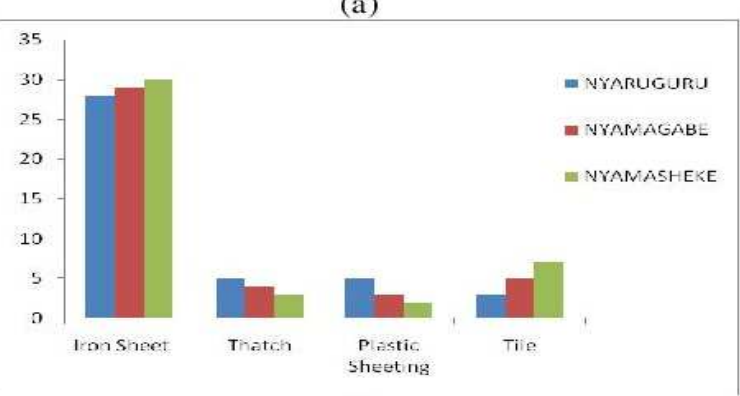

(b)

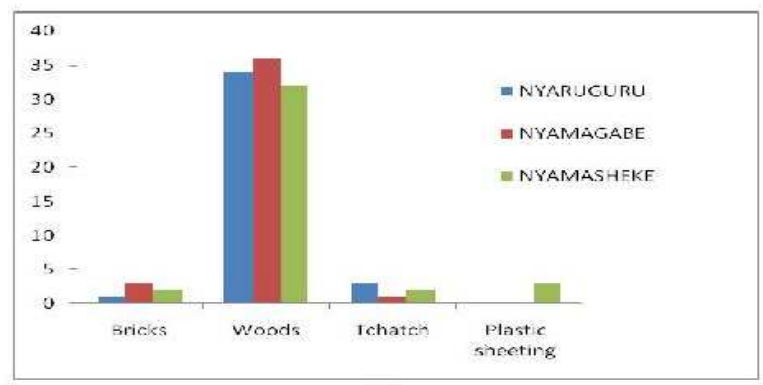

(c) 
Imperial Journal of Interdisciplinary Research (IJIR)

Vol-3, Issue-10, 2017

ISSN: 2454-1362, http://www.onlinejournal.in

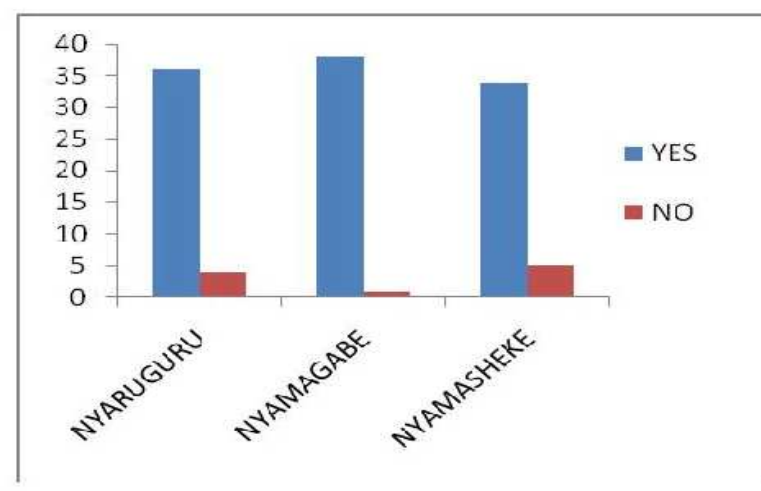

(d)

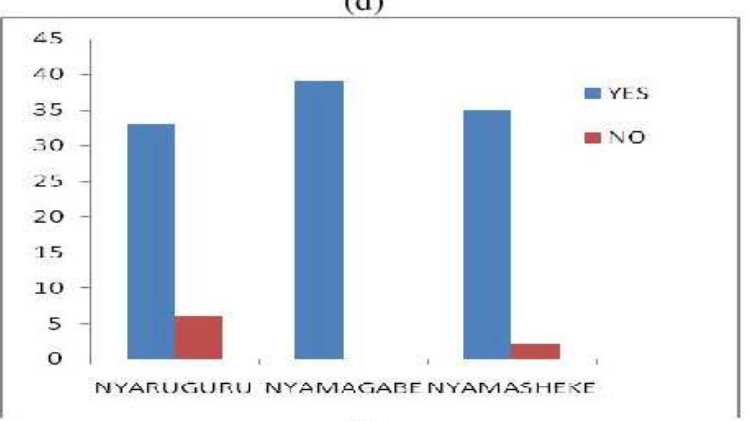

(e)

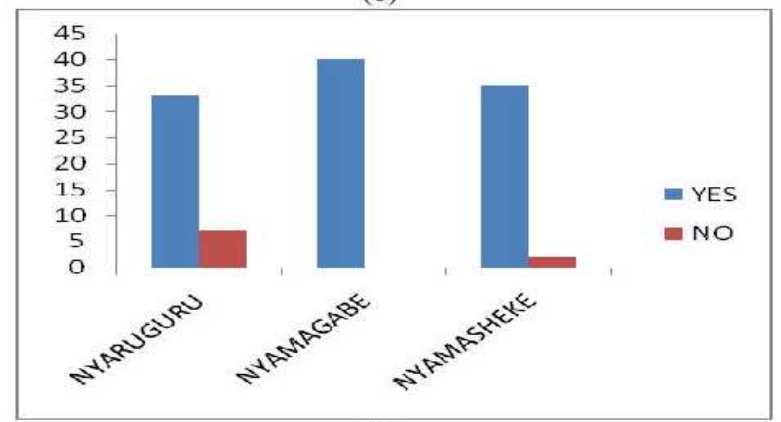

(f)

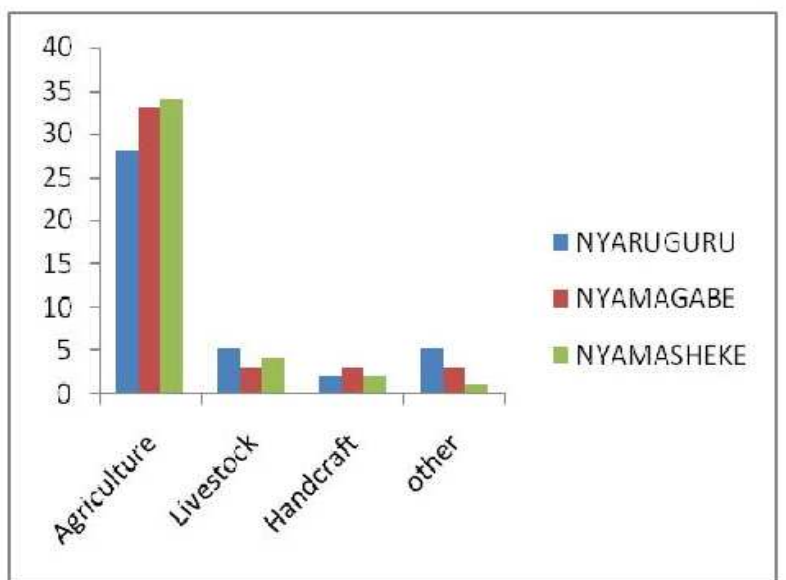

Figure 3. Roofing material (a) house construction material (b) access to health insurance (c), access to clean water (d), access to school (e) and main economic activity for the respondent (f)

\subsection{Knowledge of NNP and its associated} tourism activity.

In Nyaruguru District there are no tourism activities in the villages and all respondents in Nyamagabe and Nyaruguru Districts have tourism activities in their villages (Fig. 4a). $47.5 \%$ of the respondents benefit employment, $30.8 \%$ benefit the village development through rood construction, electricity, and other good infrastructures like schools, health centers (Fig. 4b). There are positive changes that tourism can make to the village. Tourists are seen less frequently and some respondents in Nyaruguru district who have never seen any tourist (Fig. 4c).

(a)

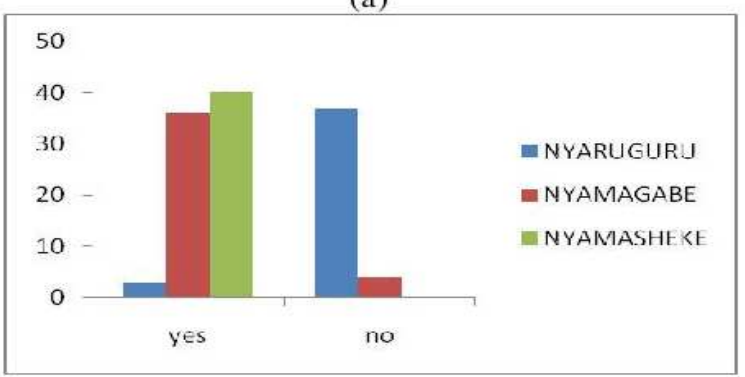

(b) 
Imperial Journal of Interdisciplinary Research (IJIR)

Vol-3, Issue-10, 2017

ISSN: 2454-1362, http://www.onlinejournal.in

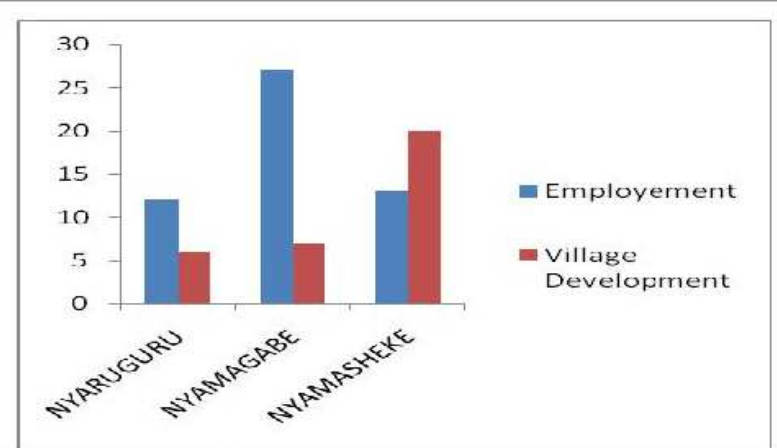

(c)

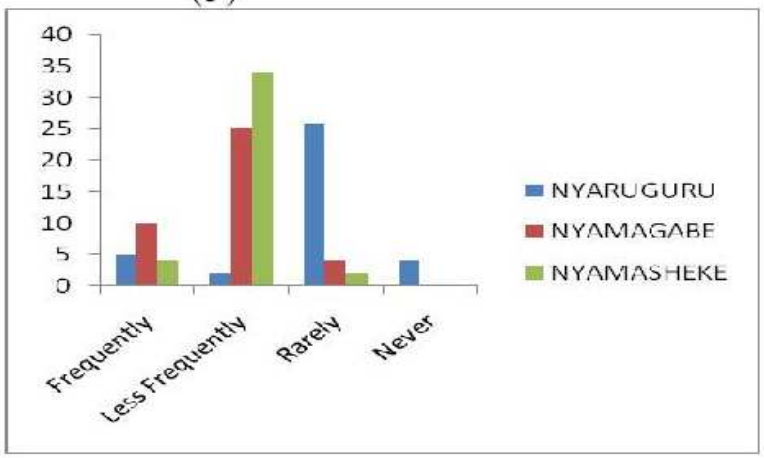

Figure 4. Knowledge of Revenue sharing Scheme (a), Livelihood improvement from the program (b), and Level of consultation on park management issues (c)

\subsection{Knowledge about Tourism Revenue Sharing Scheme}

More respondents know about revenue sharing (Fig. 5a), more respondent have improved the livelihood through livestock, schools, and good roads programs (Fig. 5b). Almost all respondents from all districts noted that there was a complete lack of any community involvement in decision-making, comprising $95 \%$ of respondents in all districts.

Respondents were not consulted over issues such as deciding on conservation priorities of NNP nor on revenue sharing projects that aimed at improving their livelihoods and they would like to be invited in decision making meetings (Fig. 5c). Although few of respondents expressed that they participated in meetings involving management and conservation of the park, one government official in the interview explained that the ORTPN, in collaboration with government, makes policies and decisions regarding the management and conservation of the park, and then communicate this to community residents through their administrative leaders (local government leaders). However, he indicated that the communities do not have the power to change any policy or any decision. (a)

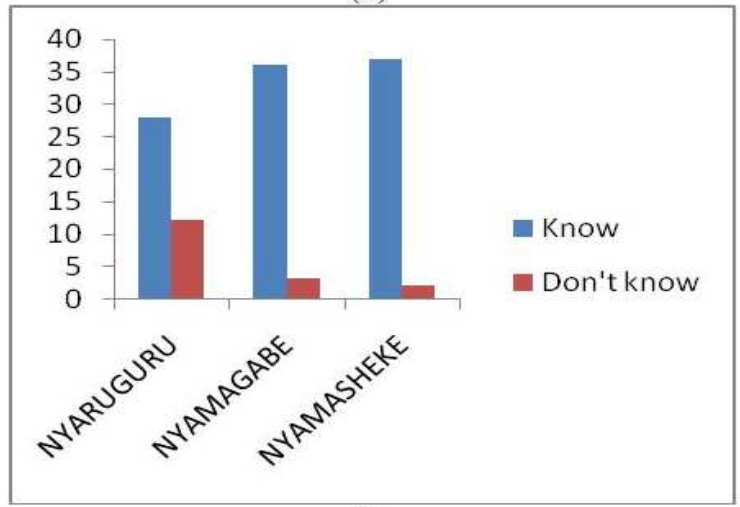

(b)

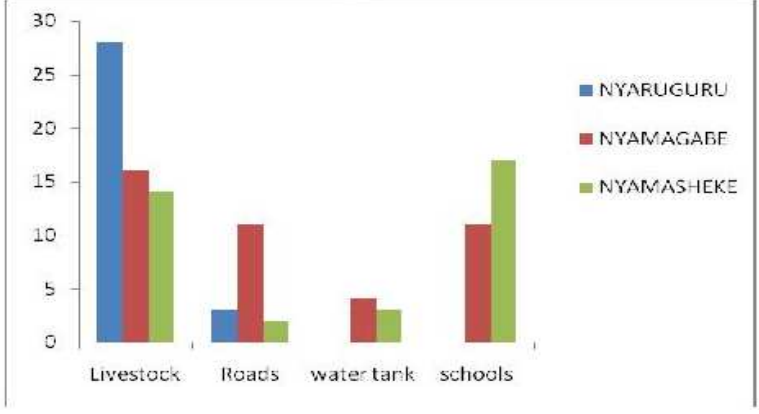

(c)

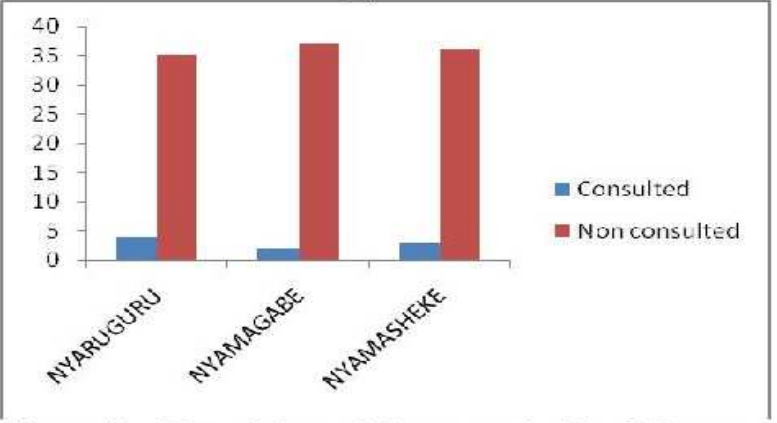

Figure 5 . Knowledge of Revenue sharing Scheme (a), Livelihood improvement from the program (b), and Level of consultation on park management issues (c)

\subsection{Tourism benefits as an incentive for conservation}

All respondents thought that tourism revenue sharing and related benefits could serve as an incentive for conserving NNP. All respondents in districts revealed that, if tourism is well managed, it can act as an incentive for conservation through stopping illegal activities (Fig. 6). 
Imperial Journal of Interdisciplinary Research (IJIR)

Vol-3, Issue-10, 2017

ISSN: 2454-1362, http://www.onlinejournal.in

Among the Challenges faced by NNP as ORTPN's staff indicated that poverty is a great challenge to the existence of the ANP. He mentioned that because the community does not have enough food, they tend to seek food from hunting in the park and practice other illegal activities like seeking fire wood to prepare their food.

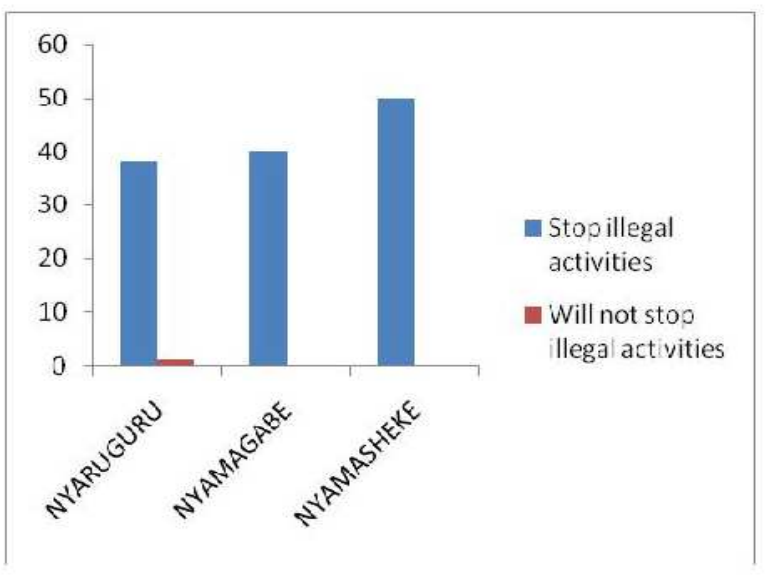

Figure 6. Tourism benefit as incentive for conservation

\section{DISCUSSION}

Nature-based tourism is seen by many as one savior of wildlife conservation, capable of generating a flow of revenue to pay the costs of conservation and to meet the needs of local communities (Adams, 2004). Local communities living around NNP have appreciated the ecological services provided to them by NNP. This appears to be a strong basis on which to improve the relationship between NNP and the local community. Furthermore, local community respondents in three districts appreciated the importance of protecting and conserving NNP.

However, this support for NNP was based largely on their appreciation of the ecological services that NNP provides. Therefore, it appears fundamental to correct the imbalance in the flow of revenue and benefits from tourism to three districts, as a way of improving community-park relations. As human populations in Rwanda have increased, and as natural habitats face increasing threats from neighboring communities, people and animals are increasingly coming into conflict over space for farmland and food. Communities living around NNP have suffered reduced crop yields, are susceptible to injury and death, as a result of which wildlife may attacked as a means both of self-defense and of gaining some compensation for the damage suffered, and this represents an increasing threat to the survival of wildlife and of conservation efforts in NNP.

Crop raiding is a critical issue for communities living around NNP and is a cause of much of the conflict between community members and NNP. Most respondents in three districts reported that crop raiding was a major threat to their economic survival. In Rwanda and around NNP in particular, communities depend on farming for their survival, so crop raiding can lead to misery and friction between local communities and wildlife. To-date, there has been little interest from managers to investigate the patterns of raiding activity by wildlife and its potential impact on farmers' food and household economic security (Hill, et al., 2002). To understand exactly how particular types of human-wildlife conflict impact on people's lives, we need to understand something of what that situation means to those individuals (Hill, et al., 2002). As one community member put it, "when our animals by mistake go to the park, they are impounded and we are either charged a fine or imprisoned, but when their wildlife comes to our fields, they don't care and expect us not to care either. Therefore, ORTPN has to accept the responsibility.

This feeling responds to Scheyvens' (1999) ecotourism framework, which spells out signs of community disempowerment when agencies initiate or implement ecotourism ventures and treat communities as passive beneficiaries by failing to involve them in decision-making, hence a majority of community members feel that they have little or no say over whether or not tourism initiatives operate or the way in which they operate. In due course, a compensation program should be implemented to ensure that local people are part of the overall management of the problem, and can participate in determining what they consider to be an appropriate compensation package. Otherwise, conflict between communities and wildlife around NNP will remain a threat to conservation and survival of many species. The issue of loss of life and livelihood requires landmark, realistic and cost effective solutions that will shift the economic burdens away from local communities to institutions charged with managing wildlife for the national benefit. In turn, this will ultimately encourage a constructive engagement between local communities and the task of conserving wildlife in their neighborhood. A new concept to share $5 \%$ of revenue deriving from tourism was proposed for implementation. Projects were identified and money has been set aside since 2002.

As contended by Tosun (2000), community involvement in tourism can be considered from at 
Imperial Journal of Interdisciplinary Research (IJIR)

Vol-3, Issue-10, 2017

ISSN: 2454-1362, http://www.onlinejournal.in

least two viewpoints: in the decision-making process and in the benefits of tourism development. This is not the same in case of NNP. Although ORPTN had already initiated projects from revenues generated in 2003 , communities at large were not involved in making decisions about which projects to implement. Districts took the lead in identifying projects for ORTPN to fund. Their participation and involvement are considered when they are having economic benefits via revenue sharing and encouraging them to operate small scale businesses such as animal husbandry, beekeeping and other small businesses. However, while much of this could help in influencing political support at the district level, there is a need to make a clear distinction between district and community needs and priorities. Otherwise, sharing of revenue from tourism will remain a weak link in the equation and will have a little impact on the major target group among local communities, who bear most of the costs of living next to NNP, and who have the greatest impact on the conservation of the park as (Tosun, 2000) have already revealed in his several studies.

Most respondents in three districts knew of the scheme to share tourism revenue. Respondents were clear that decisions made at district levels do not reach them. Respondents from three districts indicated that sharing of tourism revenues with local communities around NNP could reduce the conflict between park management and local communities and increase their participation in park management. Furthermore, respondents from three districts emphasized the significant role that sharing tourism revenue could play in improving attitudes towards NNP and in reducing illegal activities. For the conservationist, the real question is whether naturebased tourism can provides an effective incentive for communities to take conservation action (Kiss, 2004). Such incentives can take several forms. The ideal is a direct linkage, in which tourism earnings are so high that people deliberately protect biodiversity to protect that income (Kiss, 2004).

For ecotourism to promote conservation, local people must clearly benefit and understand that the benefits they receive are linked to the PA (Brandon, 1996). If benefits do not stay in local areas or are narrowly distributed, they may not provide sufficient economic incentives to reduce livelihood dependence on resources inside PAs. So far, the evidence indicates that when changes have taken place, ecotourism has been but one component of change (Brandon, 1996). For communities to benefit from tourism in NNP, considerable attention needs to be given towards their perceptions, views and understanding of tourism and conservation, and to increasing their involvement in decision-making about projects aimed at improving their livelihood.

\section{CONCLUSIONS AND RECOMMENDATIONS}

\section{A. Conclusion}

The major objective of ecotourism is to provide benefits to local communities. Therefore, the key objective of sharing revenue from tourism is to promote community conservation outreach through projects that in line with ecotourism principles, thereby to promote and enhance conservation relations and minimize negative impacts from both wildlife and local communities around NNP. For ecotourism to follow its principles, community conservation outreach projects and revenue sharing projects need to be successful in changing community attitudes and behavior towards NNP. Consequently, there is need to re-evaluate and emphasize on the following: Local community participation, community empowerment, linking benefit to conservation. The local participation has been described as "giving people more opportunities to participate effectively in development activities. It means empowering people to mobilize their own capacities, be social actors rather than passive subjects, manage their resources, make decisions and control the activities that affect their lives. Local community participation viewed as a process includes, but goes beyond, sharing social and economic benefits, and differs from beneficially approach, in which people receive benefits but are not empowered. To empower and involve local communities is to give them a degree of control. Once there has been some discussion and resolution about the benefits, how they will be distributed and for how long they will be received, then communities will know what to expect and what conditions are attached, and will directly link that to conservation. It should not just be about sharing benefits, because communities should also expect to share costs, which in turn facilitates a collective understanding and agreement on cost sharing and its enforcement. Therefore, benefits should be in line with the energy invested throughout the development phase of the project and communities should be able to see where benefits are coming from. The view is that rural populations have few alternatives to economic activities that degrade or destroy the resources. Ecotourism is seen as representing a source of income, which should in turn act as an incentive to halt destructive practices or continuing sound resource management practices.

Monitoring and evaluation should be given attention and made part of an ongoing process. It allows adjustments and changes to be made as projects unfold, developing key objectives and indicators to measure impacts of their social and economic 
Imperial Journal of Interdisciplinary Research (IJIR)

Vol-3, Issue-10, 2017

ISSN: 2454-1362, http://www.onlinejournal.in

development so as to provide useful input for future planning. Monitoring results must be carefully analyzed to determine appropriate management options that lead to specific management and awareness building.

\section{B. RECOMMENDATIONS}

Tourism activities in Nyungwe National Park should be appropriately planned, monitored and managed to ensure that they do not conflict with conservation and sustainable use of resources, as well as compromise the livelihood of local residents.

Local communities in NNP area should be engaged and should be involved in development programmes in their villages right from the start.

\section{REFERENCES}

Adams, W.M. (2004). Against Extinction: The Story of Conservation, Earthscan, London.

Brandon, K. (1996). Ecotourism and Conservation: A Review of Key Issues, Environment Department Paper No. 033. The World Bank, Washington D.C, USA.

FAO, (2005). Negotiation and mediation techniques for natural resource management by Antonia Engel and Benedikt Korf.

Goodwin, H., Kent, I., Parker, K., and Walpole, M., (1998). Tourism, Conservation and Sustainable Development: Case Studies from Asia and Africa, Wildlife and Development Series, No. 12, IIED, London.

Hawkins D. \& Khan, M. 1998. Eco-tourism opportunities for developing countries. Global

Tourism, Theobald, W. (ed), pp. 191-204. Oxford: Butterworth Heinemann.

Hvenegaard, G.T. 1994. Ecotourism: A status report and conceptual framework. The Journal of Tourism Studies, Vol. 5(2), pp 24-35.

International Institute for Environment and Development (IIED), (2009). Community management of natural resources in Africa. Impacts, experiences and future directions.

Isaacs, J.C. (2000). The Limited Potential of Ecotourism to Contribute to Wildlife Conservation, Wildlife Society Bulletin, 2000, 28(1): 61-69.

John, Terborgh and all. Making Parks work, Strategies for preserving tropical nature, pp. 365. 26

Kiss, A. (2004). Is community-based ecotourism a good use of biodiversity conservation funds, Ecology and Evolution, Vol.19, No. 5.

Kusters, K., (2009). Non-timber product trade. A trade-off between conservation and development. Assessing the outcomes of non-timber forest product trade on livelihoods and the environment, with special emphasis on the damar agroforestry in
Sumatra, Indonesia. Amsterdam: Rozenberg Publishers.

Lindberg, K. \& Hawkins, D.E. 1993. Ecotourism: A Guide for Planners and Managers. The

Ecotourism Society. North Bennington. Vermont Lindberg, K., Wood, E.W., and Engeldrum, D., (1998). Ecotourism: A Guide for Planners and Managers, Vol.2, The Ecotourism Society, North Bennington, Vermont, USA.

Mehta, H and Katee, C. (2005). Virunga Massif Sustainable Tourism Development Plan, ICCN, ORTPN, UWA, IGCP, Kigali-Rwanda.

ORTPN, (2004) Rwanda Office of Tourism and National Parks Strategic Plan 2004-2008, ORTPN, IGCP, Kigali-Rwanda.

REMA (2009). Rwanda State of Environment and outlook report-REMA (online)

REMA, (2010). Rwanda Environmental Education for Sustainable Development Strategy. A strategy and Action Plan for 2010-2015. Kigali: REMA (online).

Rwanyiziri, G., (2011). Community Conservation, Msc Biodiversity Conservation lecture, theme II.P.22-30

Sayer, J. 1991. Rainforest buffer zones: guidelines for protected areas management. Gland, Switzerland: IUCN

Scholte, P. (2010). Don't throw out the baby with the bathwater: towards a third generation of Integrated Conservation and Development, Towards ICD-3.0; unpublished

Tosun, C. \& Jenkins, C. 1998. The Evolution of Tourism Planning in Third World Countries: A Critique. Progress in Tourism and Hospitality Research, Vol. 4, pp 101-114.

Tosun, C. 2000. Limits to community participation in the tourism development process in developing countries. Tourism management, Vol. 21, pp $613-$ 633.

UNEP, (2005). Making Tourism more Sustainable: A Guide for Policy Makers, UNEP and WTO, Madrid, Spain.

Wells, M. \& K. Brandon. 1992. People and parks: linking protected areas management with local communities. Washington, DC: World Bank/World Wildlife Fund/ U.S. Agency for International Development. 
Imperial Journal of Interdisciplinary Research (IJIR)

Vol-3, Issue-10, 2017

ISSN: 2454-1362, http://www.onlinejournal.in 


\title{
APPENDIX D: Paper 4
}

\author{
International Journal of Natural Resource Ecology and Management \\ 2019; 4(6): 188-197 \\ http://www.sciencepub lishingeroup.com/j/ijnrem \\ doi: $10.11648 /$ j.ijnrem. 20190406.15 \\ ISSN: 2575-3088 (Print); ISSN: 2575-3061 (Online)
}

\section{Community Perceptions of Human-wildlife Conflicts and the Compensation Scheme Around Nyungwe National Park (Rwanda)}

\author{
Umuziranenge Gloriose \\ Department of Natural Resources and Environmental Management, Protestant Institute of Arts and Social Sciences, Huye, Rwanda
}

Email address:

u.gloriosegemail.com

\section{To cite this article:}

Umuziranenge Gloriose. Community Perceptions of Human-wildlife Conflicts and the Compensation Scheme Around Nyungwe National Park (Rwanda). International Journal of Natural Resource Ecology and Management. Vol. 4, No. 6, 2019, pp. 188-197. doi: 10.11648/j.ijnrem. 20190406.15

Received: August 19, 2019; Accepted: September 12, 2019; Published: December 6, 2019

\begin{abstract}
In African countries, crop-raiding by wild animals and human-wildlife conflicts are recurrent and common concerns for conservationists, protected areas managers and surrounding populations. At different levels, these challenges hinder the achievement of conservation goals. Although researchers have widely studied human-wildlife conflicts in Nyungwe National Park, few have examined its impact and lived experiences of local communities who are regularly facing crop-raiding by wild animals. The present study conducted in areas adjacent to the park including those affected with a high rate of crop raiding aimed to assess: (1) the community perceptions on human-wildlife conflicts and (2) the community perceptions on the compensation schemes set up to minimize the conflicts. For this purpose, a qualitative method was adopted. It relied on field semi-structured interviews with the representatives of conservation key stakeholders including local communities that experienced crop raiding. On one hand, the findings indicated that communities affected by generalized crop raiding are complaining about socio-economic and livelihood losses, food insecurity and injury. On the other hand, they showed that affected communities are not satisfied with the compensation scheme. Difficult requirements for compensation, complicated compensation procedure, rejection of compensation claims, undervalued payment and irregular compensation and delay of payments were identified as key problems that keep human-wildlife conflicts at high levels. The compensation process is so slow, so long and so costly that the victims of crop raiding abandon compensation claims. As a result, local communities continue to deal with self-defense since monetary compensation is unable to decrease the level of crop raiding. The findings call for an improved compensation scheme for reduced human-wildlife conflicts and efficient management following the model of effective compensation. Even though fencing the Park could be expensive, it would be a viable option to minimize wild-animals escape from the park. In addition, enhancing collective guiding system was proposed by the local community as their innovative strategy that could reduce crop raiding.
\end{abstract}

Keywords: Crop Raiding, Human Wildlife Conflicts, Compensation Scheme, Nyungwe National Park, Rwanda

\section{Introduction}

Worldwide in general and in Africa in particular, human-wildlife conflicts around natural forests are serious challenges for conservation initiatives by authorities and local communities [1-4]. In Africa, due to the rapid growth of the human populations, traditional land rights and agricultural regimes have changed considerably because of the scarcity of farmland [5-8]. This evolution led to the encroachment of the wildlife habitats and direct conflicts between wildlife and populations with the perception that wildlife threatens human safety, health, food, and property [8-12]. Wild animals like birds, small and big mammals and wildlife baboons manage to move around protected areas and cause damage and troubles to the community property [13]. In Africa where farmers are highly dependent on agriculture, human-wildlife conflicts always occur and they are intensified in regions where dense human populations live adjacent to protected areas, and where livestock and crop fields are major components of rural livelihoods [14-17, 8]. Today, contradictory arguments are 
provided by stakeholders to explain such conflicts. The conservationists argue that the communities around protected areas encroach on the wild animals habitat while local communities argue that wildlife attacks and damages their crops [18-20]. According to some authors, the killing of wild animals is caused by the lack of financial and socio-economic compensations for damaged crops, properties and human lives $[21,23]$. Consequently, both people and wildlife experience serious problems of crop raiding and wildlife attacks by the local community which lead to misunderstanding and conflicts between local communities and conservationists. Crop raiding by wildlife is recognized and documented in many African countries including Kenya, Uganda, Nigeria and Senegal [5, 23-26]. As wildlife attacks occur at all periods and all stages, local communities complain to feed wildlife while they are themselves starving and are affected by socio-economic losses $[1,27,8]$. To address these conflicts and challenges, many solutions have been proposed among which fences and trenches [28], socio-ec onomic inc entives for the development of the populations living in the vicinity of protected areas [29] and the guarding of crops [30-31, 18, 32, 12]. Despite strategies and actions carried out to minimize wildlife conflicts especially crop raiding, most of local communities around protected areas are still suffering from the ineffectiveness of some of the strategies. They are affected by socio-economic injustice and therefore reclaim justice through equitable compensation in the case they experience crop raiding. Compensation typically involves reimbursing with cash or in-kind payments people who have experienced wildlife damage to crops or livestock, or who have experienced personal injury or threats from wildlife $[33,5,19$, 12]. However, the compensation scheme has been criticized especially in African countries where it creates an atmosphere of mistrust and resentment due to the unfair compensation which results in direct and significant impact on human-wildlife conflict problem. In addition, compensation in form of money is criticized for many other reasons including cheating on claims, high administration costs and lack of involvement and participation of local community in the development of compensation programs that did not achieve their goals [34-37, 14, 38-39, 12]. In Rwandan protected areas in general and Nyungwe National Park (NNP) in particular, where surrounding communities and households don't have enough farmlands to ensure food security since agriculture is the main activity [40], crop raiding is also a big challenge [37, 41]. In NNP, poaching exploitation has considerable impact on conservation as the main form of wildlife overexploitation and habitat destruction [41-45]. Species such as small birds, rodents and primates are the main crop raiders in the periphery. The crossing of boundaries by wildlife and the threat of killing animals cause major problems between managers and residents neighboring the park. The crop raids prompt the shortage of food during the year, social instability and increase human pressure on natural resources and wildlife [46, 42]. Through Rwanda Development Board (RDB), the Government of Rwanda initiated a compensation program in 2012 to alleviate tensions from local communities due to crop raiding. The compensation scheme pays money for damages caused by wildlife on the basis of field pictures, assessment of damages by agronomists and compensation forms after verification of claims by Conservation animators $\left(\mathrm{ANICO}_{\mathrm{S}}\right)$ for the Compensating Agency. Since the compensation scheme has been initiated, it is reported that the human-wildlife conflicts and tensions reached a low level while, at the same time, increased traps for animal killing are observed. Since the policy of monetary compensation was initiated, lived experiences of local communities with regards to the implementation of the compensation process and how it reduces human wildlife conflicts are still missing in the context of scientific research in Rwanda [47-48, 44]. The studies conducted around protected areas in Rwanda are more quantitative and mainly focused on examining the socio-economic status of local communities [49-50], evaluating community-based conservation [51], examining impact of tourism revenue sharing [52], measuring effectiveness, efficiency and equity in payments for ecosystem services [53], and evaluating forest dependence and its implications for protected area management [37]. Since the policy of compensation was initiated in 2012 , its impact and lived experiences of the local community with regards to the compensation process and how it reduces human wildlife conflicts are still missing. Thus, the research aims to: (1) explore and understand the community's perceptions with regards to crop raiding and (2) investigate and understand how the community perceives the compensation fund and process initiated by RDB in NNP. It intends to check if local population opinions on wildlife and conservation are influenced or not by benefit scheme to offer job and support the development projects of the people living around NNP and compensation of wildlife damage to property, and to human life.

\section{Materials and Method}

\subsection{Study Area}

The Nyungwe forest was designated as a national Park in 2005 under the law $\mathrm{n}^{\circ} 22 / 2005$ on November 21, 2005. Previously, it has been under protection since 1933, when it was first gazetted as a forest Reserve. Now, NNP is one of the four Rwandan national parks and one of the largest remaining forest tracts in east-central Africa. It covers an area of 1019 $\mathrm{km}^{2}$ and is a highly diverse hotspot as a home to endemic and globally threatened species. It supplies enormous ecosystem services, including water provisioning and tourism activities [54]. NNP is located in the Albertine Rift Valley on the Congo-Nile fracture and is adjacent to Kibira National Park in Burundi in the South, forming one of the largest blocks of mountain forest in Africa [37, 42]. The park is surrounded by Nyaruguru, Nyamagabe, Karongi, Nyamasheke and Rusizi districts (Figure 1). The main socio-economic activities around NNP are agriculture, livestock breeding, petty trading and other secondary activities. The main crops that are grown in the area are sorghum, maize, corn, sweet potato, potato, 
cassava, beans, bananas, fruits, cabbages, tomatoes, carrots and coffee. NNP under the study has its periphery areas with human settlements and average farm size of 1 ha/household which is insufficient to ensure food security for an entire family since agriculture is the main activity [40]. Communities living in and around the Nyungwe forest have always relied on forest resources. They use the forest as a source of materials for construction, medicines, firewood, and grass for cattle. The people around Nyungwe National Park are primarily depending on agriculture for their livelihoods $[48,51]$. Masozera has established the link between the poverty of the local communities and the menaces to protected parks. A high percentage of the people around NNP are poor families with low education level and this is a challenge for both tourism and conservation development. He said, "The dependency on natural resources can be explained by the low agriculture income, limited access to job opportunities, food insecurity, illiteracy, and large size of local households (over six people per household) among other things [36]. In addition to poverty and population growth, poaching and crop raiding are the main form of wildlife overexploitation and habitat destruction in NNP $[42,44]$.

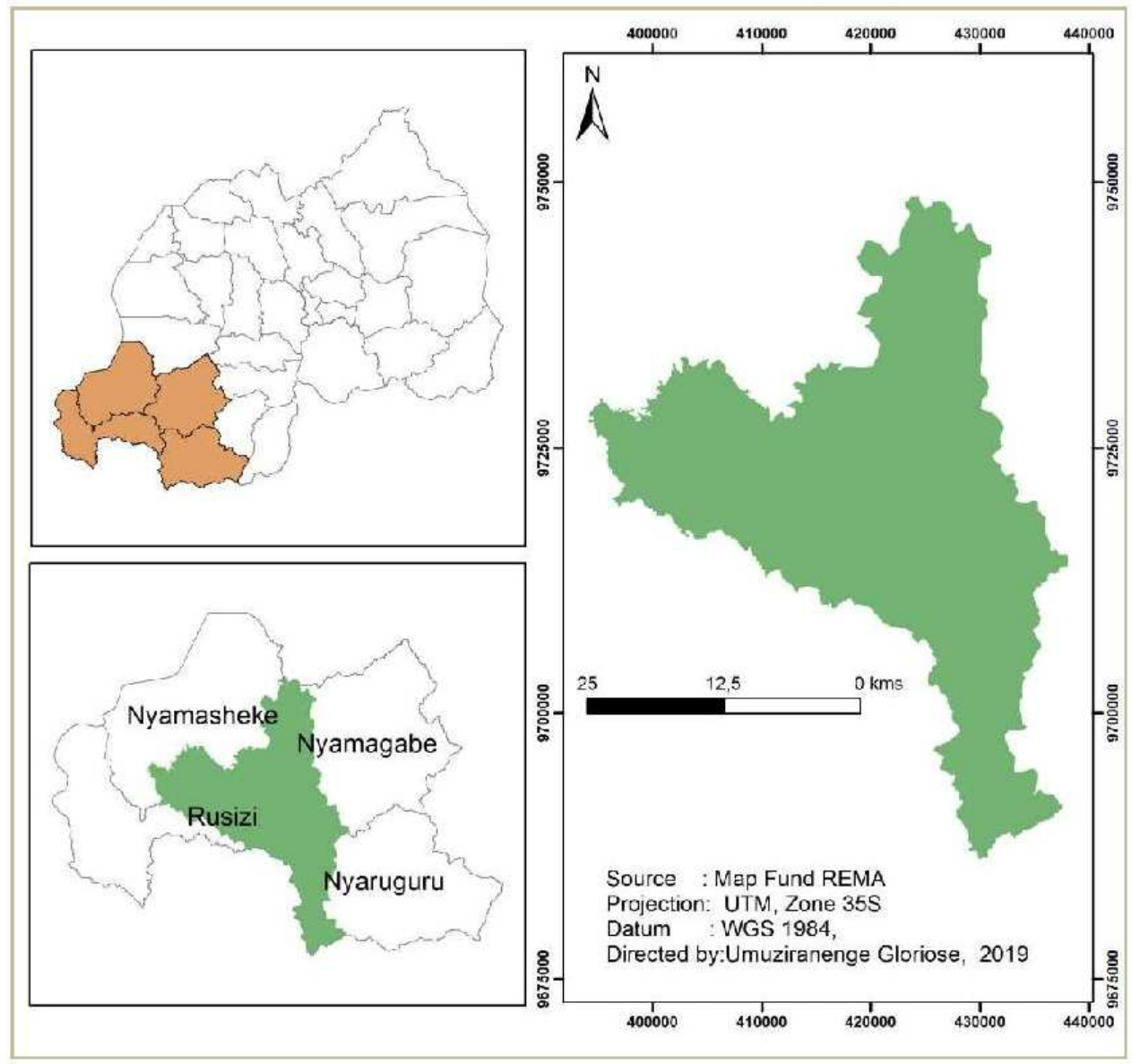

Figure 1. Location map of Nyungwe National Park.

\subsection{Research Methods and Data}

Due to the aim of the research to explore people's perceptions about crop raiding and compensation program, the qualitative method was adopted. In practice, qualitative approach is preferred when one seeks to explore how individuals interpret their experiences on a given matter [55-57]. It focuses on understanding people's beliefs, perspectives, experiences, attitudes, and opinions, perceptions about phenomena and situations or issues [58]. For the reason that the study is mainly aiming to explain how people perceive crop raiding as a big challenge in their daily life, and how their perceive and understand the compensation program, qualitative approach fits the purpose of this study because beliefs, experiences and perceptions can be effectively explored through open expression of participants. Adding to that qualitative research approach produces the broad description of participants' feelings, opinions, and experiences and interprets the meanings of their actions. It seeks to understand and interpret more local meanings, recognizes data as gathered in a context and sometimes produces knowledge that contributes to more general understandings [55-57]. In this regard, participants express their beliefs, their feelings, 
experiences and perceptions. Thus, the knowledge is constructed from the context in which it was generated. To approach the question about community perceptions on human-wildlife conflicts and compensation scheme, individual semi-structured interviews were used to allow respondents to express their personal experiences or views in their own words, which allows the interviewer to gain the interviewee's experience and knowledge [59]. This study used a theoretical sampling to progressively select participants [56] In this regard, reference was made to the grounded theory as means of generating theories from empirical data [60-61]. In this process, the size of the sample is not pre-determined. Rather, the sample size is determined by the saturation point when no new data is being emerged [56-57]. During Theoretical sampling, choice of participants, data collection and data analysis are done concomitantly [56, 55, 62]. The respondents were selected purposively based on criteria such as gender, age, professional qualification and working experience, as well as living experience, are considered in the process of sampling (Table 2). Three categories of stakeholders were considered: (1) local community members, (2) $\mathrm{RDB}$ staff, and (3) $\mathrm{NGO}_{S}$ members. The repartition and the relative importance of selected and interviewed respondents are shown in Table 1. Respondents were asked five key questions: (1) to share how they perceive the challenge of crop raiding as neighbors of the park, (2) to show how crop raiding has impacted their households, (3) to tell what has been done do resolve the issue, (4) to indicate the challenges that are still found to resolve the issue of crop raiding both on the side of the local community and RDB, and (5) to tell how they perceive the process of compensation for crop raiding. At the end, they were asked to propose strategies to overcome existing challenges in line with crop raiding and compensation process. Interviews were recorded by means of audio-recording instrument. For ethical consideration, each participant was assigned a code to ensure anonymity and confidentiality. Collected data were transcribed and analyzed using the software MAXQDA. Deductive code delivered from the existing literature were developed and supplemented with new codes emerged from the interviews [63]. Comments were coded based on whether the problem is related to direct economic loss, food insecurity, physical injury, Government strategy to deal with crop raiding and perceptions with regards to the compensation process. Emerged perceptions were added in the coding system to be analyzed and compared to the theory of effective compensation model (Figure 2).

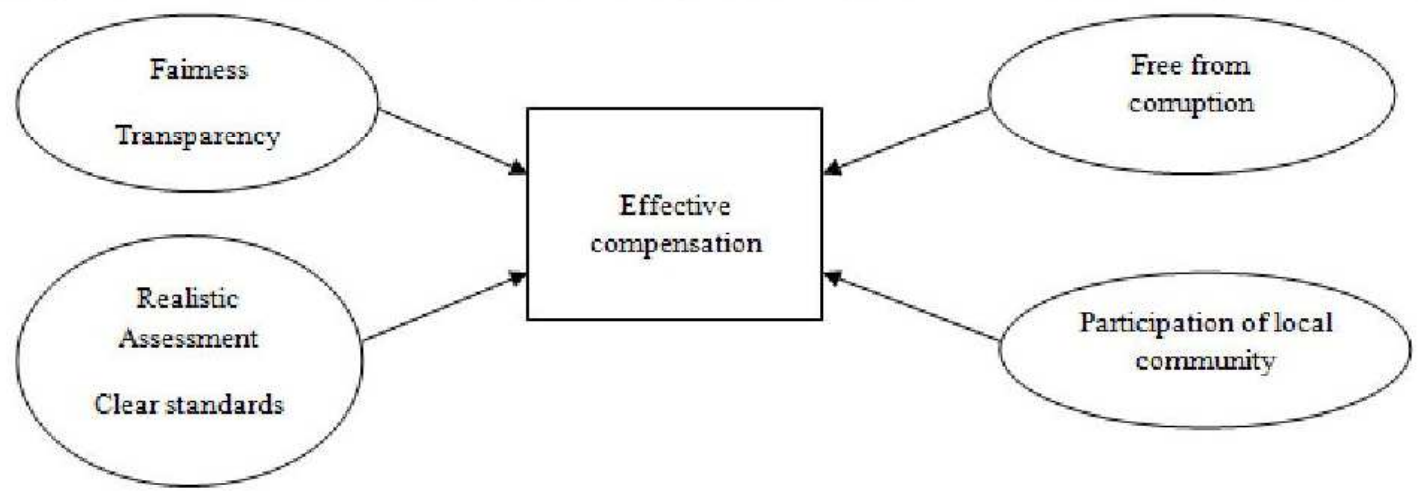

Figure 2. Model of effective compensation adapted from [64].

Data analysis was conducted using content analysis considering the views of respondents to the best information regarding the research questions [65].

Table 1. Repartition and relative importance of the participants to interviews.

\begin{tabular}{lll}
\hline Category of Stakeholders & Institutions & Number of Participants \\
\hline Local Communities & Park's surrounding Communities & 15 \\
Decision makers & Rwanda Development Board & 3 \\
Conservation NGOs & Wildlife Conservation Society & 2 \\
Total & & 20 \\
\hline
\end{tabular}

The local community is the social focus of this study, as they are placed as the change agents of the future in the policy, public debates and the success of natural resources conservation in Rwanda. Furthermore, it was presumed that communities are significant actors in conservation process and would, thus, provide important views about crop raiding as a challenge in their daily life and in the conservation process; how they perceive the compensation process and strategies to improve it. The governmental institution RDB was included as decision makers and the primary actors in conservation of natural resources in Rwanda. Their views concerning crop raiding and the process of compensation are important for understanding key problems and later help in formulating better recommendations for the successful conservation of the Park. In terms of the three groups of stakeholders, local community, decision makers here RDB and NGOS, representatives from different community conservation programs were included. 
Table 2. Characteristics of the respondents.

\begin{tabular}{|c|c|c|c|c|c|c|c|c|c|c|c|}
\hline Sampling Criteria & Interviewees Codes & WCS1 & LC1 & WCS2 & RDB1 & LC2 & LC3 & LC4 & LC5 & LC6 & LC7 \\
\hline \multirow{6}{*}{ Age Years } & $25-30$ & & & & $\mathrm{x}$ & & & & & & \\
\hline & $30-35$ & & & & & & & & & & \\
\hline & $35-40$ & $\mathrm{x}$ & & $\mathrm{x}$ & & $\mathrm{x}$ & & & & $\mathrm{x}$ & \\
\hline & $40-45$ & & & & & & $\mathrm{x}$ & $\mathrm{x}$ & & & \\
\hline & $45-50$ & & $\mathrm{x}$ & & & & & & $\mathrm{x}$ & & \\
\hline & $\geq 50$ & & & & & & & & & & $\mathrm{x}$ \\
\hline \multirow{3}{*}{ Gender } & $\mathrm{F}$ & & & & & $\mathrm{x}$ & $\mathrm{x}$ & $\mathrm{x}$ & & & \\
\hline & M & $\mathrm{x}$ & $\mathrm{x}$ & $\mathrm{x}$ & $\mathrm{x}$ & & & & $\mathrm{x}$ & $\mathrm{x}$ & $\mathrm{x}$ \\
\hline & $1-5$ & & & & $\mathrm{x}$ & & & & & & \\
\hline \multirow{4}{*}{$\begin{array}{l}\text { Working and living } \\
\text { experience Years }\end{array}$} & $5-10$ & $\mathrm{x}$ & & & & & $\mathrm{x}$ & & & & \\
\hline & $10-15$ & & & $\mathrm{x}$ & & & & & & & \\
\hline & $15-20$ & & & & & $\mathrm{x}$ & & & & & \\
\hline & $>20$ & & $\mathrm{x}$ & & & & & $\mathrm{x}$ & $\mathrm{x}$ & $\mathrm{x}$ & $\mathrm{x}$ \\
\hline \multicolumn{12}{|c|}{ Table 2. Contimued } \\
\hline \multirow[t]{3}{*}{ Sampling Criteria } & Interviewees Codes & RDB2 & RDB3 & LC8 & LC9 & LC10 & LC11 & LC12 & LC13 & LC14 & LC15 \\
\hline & $25-30$ & & & & & & & & & & \\
\hline & $30-35$ & $\mathrm{x}$ & & & & & & & & & \\
\hline \multirow{4}{*}{ Age Years } & $35-40$ & & $\mathrm{x}$ & & & & $\mathrm{x}$ & & & & $\mathrm{x}$ \\
\hline & $40-45$ & & & $\mathrm{x}$ & & & & & & $\mathrm{x}$ & \\
\hline & $45-50$ & & & & & & & $\mathrm{x}$ & $\mathrm{x}$ & & \\
\hline & $\geq 50$ & & & & $\mathrm{x}$ & $\mathrm{x}$ & & & & & \\
\hline \multirow{3}{*}{ Gender } & $\mathrm{F}$ & & & $\mathrm{x}$ & & & $\mathrm{x}$ & & $\mathrm{x}$ & $\mathrm{x}$ & $\mathrm{x}$ \\
\hline & M & $\mathrm{x}$ & $\mathrm{x}$ & & $\mathrm{x}$ & $\mathrm{x}$ & & $\mathrm{x}$ & & & \\
\hline & $1-5$ & $\mathrm{x}$ & & & & $\mathrm{x}$ & & & & & \\
\hline \multirow{4}{*}{$\begin{array}{l}\text { Working and living } \\
\text { experience Years }\end{array}$} & $5-10$ & & $\mathrm{x}$ & & & & & & & & \\
\hline & $10-15$ & & & & & & & & & & \\
\hline & $15-20$ & & & & & & $\mathrm{x}$ & & & $\mathrm{x}$ & $\mathrm{x}$ \\
\hline & $>20$ & & & $\mathrm{x}$ & $\mathrm{x}$ & & & $\mathrm{x}$ & $\mathrm{x}$ & & \\
\hline
\end{tabular}

\section{Results and Discussion}

\subsection{Community's Perceptions on Hum an-wildlife Conflicts}

The findings obtained on the community's perceptions on Human-Wildlife Conflicts and Compensation scheme by means of the coding system are shown in the Table 3 presented below.

Table 3. Community's perceptions on Human-Wildife Conflicts and Compensation process.

\begin{tabular}{|c|c|c|}
\hline Parent code & Codes & Coded segments of all documents \\
\hline \multirow{2}{*}{ Human-Wild life Conflicts } & Injuries & 3 \\
\hline & Crop raiding & 19 \\
\hline \multirow{6}{*}{ Perceptions about Compensation process } & Loss of compensation files & 1 \\
\hline & Long process & 9 \\
\hline & Subjective assessment & 6 \\
\hline & Expensive process & 6 \\
\hline & Not fair & 10 \\
\hline & No clear standards & 3 \\
\hline \multirow{6}{*}{ Local community wishes } & Ease and improve the process of compensation & 5 \\
\hline & Increase collaboration and partnership approach & 6 \\
\hline & Collective guarding sytem & 8 \\
\hline & Increase financial support & 5 \\
\hline & Continuous teaching and trainings & 6 \\
\hline & Fencing the park & 9 \\
\hline \multirow{2}{*}{ Government strategies } & Raising awareness & 15 \\
\hline & Financial support & 20 \\
\hline
\end{tabular}

The research findings of this study clearly show that most of participants interviewed rely on subsistence agriculture for their livelihood. Crop raiding was identified as the main challenge faced by farmers because the local community claims to have lost crops to wildlife raid. All types of the crops including maize, vegetables, and others were devastated. They 
were primarily raided by baboons, colobus monkeys, mangabeys and chimpanzees mainly during day time. According to respondents, the more dangerous and devastating animal species are baboons and chimpanzees. The human-wildlife conflicts continue to cause economic and livelihood losses to local communities in the boundary of NNP. Human-wildlife conflicts intensify during the dry season because of limited food available in NNP that force wildlife to damage crops and rise up the conflict between communities and wild animals. This finding was confirmed by previous studies conducted in Uganda [34]. These results are confirmed by other studies that indicated that the problem of crop damage is one of the most prevalent conflicts across the African continent $[66,8]$ and remains common due to the inefficient crop protection strategy and easy access to the farmer's land by wildlife [67].

The crop raiding affects the socio-economic improvement of rural communities by reducing financial income of farmers and negatively impact their health, education and economical status of the population. Wildlife can cause direct material and economic damage to crops, livestock, game species, and property $[39,12,8]$. Indeed, the crops play an important economical source for the populations because they supply food products to local small markets and to big cities in the region. To give an example, the losses of maize, an important crop in the study area are likely to cause an unbalanced effect on nutrition, particularly among children. This is also confirmed by a previous research for the case of the Volcano national Park in Rwanda [50]. Respondents indicate that wildlife attack on the communities which results in injuring people and to revenge people also kill the wildlife. This is confirmed by other studies conducted in Africa [21-23]. The crop losses to wildlife are not related only to an economic pressure on farming households. The losses encompassed many other fields in communities, including time and labor spent an increase of the need to guard the crops, which add the labor and disturbance of children's education due to their contribution in crop guarding as already proved by a study case in Sumatra [68]. In some cases, the risk of family members injury from wildlife, the diseases transmission and human mortality are expected as indicated by other studies [ 69 , 3]. Findings indicate that local communities are facing serious negative consequences, including food insecurity. They indicated that crop raiding affected people who failed to feed their respective families, especially children, and therefore, malnutrition problems persist in some households. This finding confirms the strong link between crop raids and shortage of food during the year, social instability and increased human pressure on natural resources and wildlife as described by previous studies $[46,42]$. The crop raiding also affect students' performance in schools and parents confirmed that the loss of agricultural production impeded the education programs as their economy relied up the agriculture production activity. In addition, parents are not capable of paying fees or providing food for school lunches, which contribute to the school children dropping out. People expressed fear of wild animals' attacks and indicated that most of the time, the attacks occur when they are guarding their crops. The strategy of preventing the invasion of wildlife relies on sensitizing local populations, creating guarding groups and setting up crops that are not preferred by baboons, specifically. The farmers are required to adopt the new strategy for crop protection that scares baboons away from their fields considering the important conflicts existing between people and wild animals as already reported by other studies $[10,66,8]$. On one hand, local populations, being the victims of the depredation of crops, use the technique of guarding the field through the use of children to protect their crops. However, the use of children for the guarding of fields and crops has negative impacts on school performances as indicated by other studies $[30-31,18,70,32,12]$. They organize a surveillance group against animals. The guarding strategy seems not to be efficient despite the presence of buffer zones. On the other hand, some of the populations affirm that this strategy is effective because the baboons do not easily invade the crops at the time of the guarding that starts from the beginning of the agricultural period and ends at the crop harvest. People are aware of and manifest their concern about benefits of living along-side wildlife, such as gaining jobs to guide the tourists in NNP. The compensation scheme is considered when wildlife attacks villages and damages the crops of community members. The following section shows how the compensation fund is managed and how local communities perceive it.

\subsection{Community's Perceptions on Compensation Scheme Process}

The findings showed that crop damages caused by wild animals have often been evaluated by a joint committee of local authorities and park staff responsible for community conservation and compensation process. To access financial compensation, damage from crop raiding must be clear and obvious to apply for compensation (flattened or damaged crops) and local people claimants should be able to provide evidence. In practice, the evidences are made of photographs, $\mathrm{ANICO}_{\mathrm{S}}$ ' reports verify ing a wild animal caused the damage and testimonies from local government leaders like village or cell leaders. The findings indicated in Table 2 showed that local communities are not satisfied with the compensation scheme due to the following main reasons: (1) low awareness of compensation, (2) little payment compared to crops damages and human attacks and (3) the delay of the payment. The interview with local community members indicated that the process of compensation is not easy. The requirement of presenting photos of wild animals during the crop raiding in the respective fields is very difficult to meet. The respondents claimed that the process of compensation took too long from the local administration to the headquarters in Kigali. This always creates conflicts between decision makers and local communities. The weaknesses and inefficiency of the compensation scheme confirm the findings of other studies $[71,35-37,14,38-39,12]$. In fact, for the African countries that pay compensation for damages caused by wildlife, the compensation procedure is so long that the victims abandon 
claims. The compensation system is not in place to diminish the damages caused by wildlife conflicts considered as natural disasters $[72,73]$. As indicated by other studies, the failure of most compensation schemes is related to the following reasons: (1) bureaucratic incompetence, (2) corruption, (3) fraud of all kinds, including falsified complaints, (4) the time and cost involved and (5) the moral hazards and practical obstacles that must be overcome. In addition, the compensation systems are not easy to manage because of required reliable and mobile staff capable of objectively verifying and evaluating damages to large areas as established by previous studies [74, 64]. This often leads to delays in decision making, undervalued payment, irregular or inappropriate compensation, or the rejection of compensation claims $[72,74,39,12]$. According to many respondents, compensation agents verify claims on the field by visual assessment and decide on the amount of the money to compensate. However, this is seen by scholars as subjective in visual assessment that leads to conflicts and both under and overcompensation is counterproductive in the long run (Watve and al, 2016). This situation impoverishes the applicant population, which depends basically on agriculture. Moreover, monetary compensation is criticized because of the main three reasons: (1) it is unable to decrease the level of the problem of crop raiding, (2) it is expensive and slow to administer and (3) it has never sufficient funds to cover all compensation claims. However, it has the merit of reducing the incentive for self-defense by farmers. Compensation scheme should go beyond cash payments for direct losses, which we have found to be only one aspect of the human wildlife conflict problem. For instance, compensation of lost critical food resources associated with protected wildlife could be provided "in kind" in the short-term; innovative approaches to compensation elsewhere have repaid losses with replacement of animals, grains, or seeds [75]. The local community wishes to be paid on time and suggests the increase of the fund allocated to the compensation scheme, especially crop damages and human attacks.

\section{Conclusion}

The study on the community perceptions of human-wildlife conflicts and the compensation Scheme around Nyungwe National Park shows that since the last decade, number of strategies of which crop guarding and compensation schemes have been experienced to address the problems of crop raiding by wild animals and recurrent human wildlife conflicts. The study that aimed to assess community perceptions on human-wildlife conflicts and the compensation scheme as an efficient strategy for minimizing human-wildlife conflicts and developing a good harmony between stakeholders for sustainable natural resources management led to interesting findings. The study shows that the damages of crops by wildlife are the source of human-wildlife conflicts. It indicated that all kind of crops including maize, beans, sorghum and potatoes are ravaged mainly by baboons, chimpanzees, mangabeys and mountain monkeys. It also reveals that most of the people living in the study area are victims of crop depredation and that there has not yet been effective strategy to minimize the frequency of crop raiding. Indeed, the compensation scheme and process seems not to work and is not effectively addressing human-wildlife conflicts. In fact, the study shows that the compensation scheme is still complicated and takes long to provide compensations in cases they are accepted. As a result, people affected by the phenomenon of crop raiding are complaining about socio-economic and livelihood losses that lead to the degradation of their relationship with park managers and to the development of self-defense activities. The population ascertains that improving the compensation scheme in a way that it facilitates local community to be compensated could provide a solution to minimize human-wildlife conflicts. Due to this, conservation organizations in collaboration with local communities could continue to develop innovative and sustainable solutions to address human-wildlife conflicts with relation to the realities on the ground. The study suggests the development of other solutions based on non monetary compensation forms like animals, grains or seeds in replacement of lost food resources associated with protected wildlife. The compensation scheme should go beyond cash payments for direct losses, which we have found to be only one aspect of the human wildlife conflicts. Moreover, the increase of the fund allocated to the compensation scheme and on time payments are suggested to repair more efficiently crop damages and human attacks and to minimize related human-wildlife conflicts. Furthermore collective guarding system was proposed as an innovative strategy from the local community and should be enhanced. Even though the local community advocate for fencing the park, they still perceive this strategy as expensive but still it could be a good strategy to reduce wild animals break out from the park.

\section{References}

[1] Hill CM. 2004. Farmers' perspectives of conflict at the wildlife-agriculture boundary: some lessons learned from Afric an subsistence farmers. Human Dimensions of Wildlife 9: 279-86.

[2] Dickman, A. J. (2010). Complexities of conflict: the importance of considering social factors for effectively resolving human-wild life conflict. Animal conservation, 13 (5), 458-466.

[3] Mc Guinness S, Taylor D. 2014. Farmers' perceptions and actions to decrease crop raiding by forest-dwelling primates around a Rwandan forest fragment. Human Dimensions of Wildlife 19: 179-90.

[4] Mir, Z. R., Noor, A., Habib, B., \& Veeraswami, G. G. (2015). Attitudes of local people toward wildlife conservation: a case study from the Kashmir Valley. Mountain Research and Development, 35 (4), 392-401.

[5] Naughton-Treves L. 1998. Predicting patterns of crop damage by wildlife around Kibale National Park, Uganda. Conservation biology 12: 156-68. 
[6] Headey, D., Jayne, T. S., 2014. Adaptation to land constraints: Is Africa different? Food Policy. 48, 18-33.

[7] Holden, S. T., \& Otsuka, K. (2014). The roles of land tenure reforms and land markets in the context of population growth and land use intensification in Africa. Food Policy, 48, 88-97.

[8] Nicole, B. F. (2019). An Assessment of the Human-Wildlife Conflict across Africa. In Wildlife Population Monitoring. Intech Open.

[9] Siex KS, Struhsaker TT. 1999. Colobus monkeys and coconuts: a study of perceived human-wildlife conflicts. Journal of Applied Ecology 36: 1009-20.

[10] Distefano E. 2005. Human-Wildlife Conflict worldwide: collection of case studies, analysis of management strategies and good practices. Food and Agricultural Organization of the United Nations (FAO), Sustainable Agriculture and Rural Development Initiative (SARDI), Rome, Italy. Available from: FAO Corporate Document repository http://www. fao. org/documents.

[11] Peterson MN, Birckhead J, Leong K, Peterson MJ, Peterson TR. 2011. Rearticulating the myth of human-wildlife conflict. Conserv. Lett. 3: 74-82

[12] Nyhus, P. J. (2016). Human-wildlife conflict and coexistence Annual Review of Environment and Resources, 41, 143-171.

[13] Oerke E-C, Dehne H-W, Schönbeck F, Weber A. 2012. Crop production and crop protection: estimated losses in major food and cash crops: Elsevier.

[14] Nyhus PJ, Osofsky SA, Ferraro P, Madden F, Fischer H. 2005. Bearing the costs of human-wildlife conflict: the challenges of compensation schemes. CONSERVATION BIOLOGY SERIES-CAMBRIDGE- 9: 107.

[15] Sifuna N. 2005. Providing compensation for damage caused by wildlife: a case study of Kenya with particular reference to elephants. Journal of social development in Africa 20.

[16] Tweheyo M, Hill CM, Obua J. 2005. Patterns of crop raiding by primates around the Budongo Forest Reserve, Uganda. Wildlife Biology 11: 237-48.

[17] Pérez E, Pacheco LF. 2006. Damage by large mammals to subsistence crops within a protected area in a montane forest of Bolivia. Crop protection 25: 933-9.

[18] Sitati NW, Walpole MJ, LEADER-WILLIAMS N. 2005. Factors affecting susceptibility of farms to crop raiding by Afric an elephants: using a predictive model to mitigate conflict. Journal of applied ecology 42: 1175-82.

[19] Laudati AA. 2010. The encroaching forest: struggles over land and resources on the boundary of Bwindi Impenetrable National Park, Uganda. Society and Natural Resources 23 : 776-89.

[20] Bowen-Jones, E. (2012). Tackling Human-wildlife Conflict: A prerequisite for linking conservation and poverty alleviation. Poverty and Conservation Learning Group Discussion Paper, $6(06), 26$.

[21] Mengue-Medou C. (2002). Les aires protégées en Afrique: perspectives pour leur conservation. Vertigo [en ligne, la revue électronique en sciences de l'environnement]. 2002, vol. $3, \mathrm{n}^{\circ} 1$, avril 2002, $19 \mathrm{p}, \quad$ Disponible sur http://vertigo.revues. org/index4126.html.
[22] Colchester M. (2003). Nature sauvage, nature sauvée? Peuples autochtones, aires protégées et conservation de la biodiversité Mouvement mondial pour les forêts tropicales, (WRM) et Fonds mondial pour la nature (WWF), $154 \mathrm{p}$.

[23] Nouidemona J. D (2004). La problématique des activités humaines dans les aires classées: Cas du Parc National du Delta du Saloum (Sénégal). Mémoire de DEA. Université Cheikh Anta Diop de Dakar, Institut des Sciences de l'Environnement, 95 p.

[24] Webber A, Hill C, Reynolds V. 2007. Assessing the failure of a community-based human-wildlife conflict mitigation project in Budongo Forest Reserve, Uganda. Oryx 41: 177-84.

[25] Wanyingi, n. J. (2016). Determinants of human-elephant conflicts in shimba hills ecosystem, Kenya (doctoral dissertation).

[26] Ogunjobi, J. A., Halidu, S. K., Odebiyi, B. R., \& Fxentirimam, I. J. (2018). Crop raiding pattern of the African elephant (Loxodonta africana) in farms around Kamuku National Park, Nigeria. African Journal of Agriculture Technology and Environment Vol, 7 (2), 174-187.

[27] Naughton-Treves L. 1997. Farming the forest edge: vulnerable places and people around Kibale National Park, Uganda. Geographical Review 87: 27-46.

[28] Hockings K. 2009. Best practice guidelines for the prevention and mitigation of conflict between humans and great apes: IUCN.

[29] Cantiani M, Geitner C, Haida C, Maino F, Tattoni C, et al. 2016 Balancing economic development and environmental conservation for a new governance of Alpine areas. Sustainability 8: 802 .

[30] Haule, K. S., Johnsen, F. H., \& Maganga, S. L. S. (2002). Striving for sustainable wildlife management: the case of Kilombero Game Controlled Area, Tanzania. Journal of environmental management, 66 (1), 31-42.

[31] Kagoro-Rugunda, G. (2004). Crop raiding around Lake Mburo National Park, Uganda. African Joumal of Ecology, 42 (1), 32-41.

[32] Hill, Catherine M. 2015. "Perspectives of "Conflict" at the Wildlife-Agriculture Boundary: 10

[33] Tchamba M. 1996. History and present status of the human/elephant conflict in the Waza-Logone region, Cameroon, West Africa. Biological Conservation 75: 35-41.

[34] Hill CM. 2000. Conflict of interest between people and baboons: crop raiding in Uganda. International journal of primatology 21: 299-315.

[35] Schwartzman S, Moreira A, Nepstad D. 2000. Rethinking tropical forest conservation: perils in parks. Conservation Biology 14: 1351-7.

[36] Masozera MK. 2002. Socioeconomic impact analysis of the conservation of the Nyungwe forest reserve, Rwanda. University of Gainesville, Florida.

[37] Masozera MK, Alavalapati JR. 2004. Forest dependency and its implications for protected areas management: a case study from the Nyungwe Forest Reserve, Rwanda. Scandinavian Journal of Forest Research 19: 85-92.

[38] Zabel A, Holm-Muller K. 2008. Conservation performance payments for carnivore conservation in "Sweden. Conserv. Biol. 22: 247-51. 
[39] Linnell JDC, Rondeau D, Reed DH, Williams R, Altwegg R, et al. 2010. Confronting the costs and conflicts associated with biodiversity. Anim. Conserv. 13: 429-31.

[40] NISR, (2018). EICV5: The fifth integrated household living conditions survey. Kigali-Rwanda.

[41] Crawford, A. (2012). Conflict-Sensitive Conservation in Nyungwe National Park: Conflict analysis. Int. Ins. Sust. Dev. Report.

[42] Plumptre, A. J. (2012). The Ecological Impact of Long-term Changes in Africa's Rift Valley. Nova Science Publishers.

[43] REMA, (2015) Study to establish a national list of threatened terrestrial ecosystems and species in need of protection inRwanda. Kigali, Rwanda.

[44] Imanishimwe, A., Niyonzima, T., \& Nsabimana, D. (2018). Contribution of Community Conservation and Ecotourism Projects on Improving Livelihoods and Sustainable Biodiversity Conservation in and around Nyungwe National Park (NNP). J Tourism Hospit, 7 (363), 2167-0269.

[45] Grace, A. (2019). Assessment of abundance, distribution and threats on Prunus afric ana in Rwanda, Case study: Nyungwe and Gishwati-Mukura National Parks. Final Report.

[46] Plumptre AJ, Masozera M, Fashing PJ, McNeilage A, Ewango C, et al. 2002. Biodiversity surveys of the Nyungwe forest Reserve in SW Rwanda. Wildlife Conservation Society Working Papers 19: 1-95.

[47] Tusabe R, Habyalimana S (2010). From poachers to park wardens: Revenue sharing scheme as an incentive for environment protection in Rwanda. In Mountain Forum Bulletin. 2010; 10 (1): 91-93.

[48] Kamuzinzi PK, Shukla J, Ndabaga E (2015). The effectiveness of Rwanda Development Board tourism revenue sharing program towards local community socio-economic development: A case study of Nyungwe National Park. European Journal of Hospitality and Tourism Research. 2015; 3 (2): 47-63.

[49] Plumptre, A. J., Kayitare, A., Rainer, H., Gray, M., Munanura, I., Barakabuye, N. and Namara, A. (2004). The socio-ec onomic status of people living near protected areas in the Central Albertine Rift. Wildlife Conservation Society (WCS), New York: 10.

[50] Bush GK, Ikirezi M, Daconto G, Gray M, Fawcett K. 2010. Assessing impacts from community conservation interventions around Parc National des Volcans, Rwanda. Study funded by the Rwanda Environment Management Authority (REMA).

[51] Rutebuka, E., Nsabimana, D., \& Gross-Camp, N. (2012). Evaluation of community based conservation around protected areas in Rwanda, Nyungwe National Park.

[52] Munanura, I. E., Backman, K. F., Hallo, J. C., \& Powell, R. B. (2016). Perceptions of tourism revenue sharing impacts on Volcanoes National Park, Rwanda: a Sustainable Livelihoods framework. Journal of Sustainable Tourism, 24 (12), 1709-1726.

[53] Martin, A., Gross-Camp, N., Kebede, B., \& Mc Guire, S. (2014) Measuring effectiveness, efficiency and equity in an experimental Payments for Ecosystem Services trial. Global Environmental Change, 28, 216-226.
[54] Banerjee, O., Lal, P., Wolde, B., Masozera, M., Burli, P., Alavalapati, J., Ranjan, A.,... \& Mugabo, R. (2017). Valuing visitor services and access to protected areas: The case of Nyungwe National Park in Rwanda. Tourism Management, 61, 141-151.

[55] Creswell, J. W. (1998). Qualitative research and research design: Choosing among five traditions. London: Thousand Oaks.

[56] Savin-Baden, M. \& Major, C. H. (2013). Qualitative research: The essential guide to theory and practice. London \& New York: Routledge.

[57] Silverman, D. (2014). Interpreting qualitative data ( $4^{\text {th }} \mathrm{Ed}$.). Los Angeles, London, New Delhi, Singapore \& Washington DC. SAGE

[58] MacMillan, J. \& Schumacher, S. (2014). Research in education: Evidence-based inquiry ( $7^{\text {th }}$ Ed.). Harlow: Pearson Education Limited.

[59] Patton, M. Q. (2002). Qualitative Research and Evaluation Methods. Thousand Oaks: Sage.

[60] Charmaz, K. (2014). Constructing grounded theory. sage.

[61] Thornberg, R, Perhamus, L., \& Charmaz, K. (2014). Grounded theory. Handbook of research methods in early childhood educ ation: Research methodologies, 1, 405-439.

[62] Mayring, P. (2014). Qualitative content analysis: theoretical foundation, basic procedures and software solution. URN: http://nbn-resolving. de/urn:nbn:de:0168-ssoar-395173.

[63] Kennedy, B. L., \& Thomburg, R. (2018). Deduction, induction, and abduction. The SAGE handbook of qualitative data collection, 49-64.

[64] Watve, M., Patel, K, Bayani, A., \& Patil, P. (2016). A theoretical model of community operated compensation scheme for crop damage by wild herbivores. Global Ecology and Conservation, 5, 58-70.

[65] Cohen, L., Manion, L., \& Morrison, K. (2002). Research methods in education. routledge.

[66] Ladan SI. 2014. Examining human wild life conflict in Africa Presented at International Conference on Biological, Civil and Environmental Engineering (BCEE-2014) Retrieved from: http://dx. doi. org/10.15242/IICBE. C-0314043 on May.

[67] Okello MM. 2005. Land use changes and human-wildlife conflicts in the Amboseli Area, Kenya. Human Dimensions of Wildlife 10: 19-28.

[68] Linkie M, Dinata Y, Nofrianto A, Leader-Williams N. 2007. Patterns and perceptions of wildlife crop raiding in and around Kerinci Seblat National Park, Sumatra. Animal Conservation 10: $127-35$

[69] Thirgood S, Woodroffe R, Rabinowitz A. 2005. The impact of human-wildlife conflict on human lives and livelihoods. CONSERVATION BIOLOGY SERIES-CAMBRIDGE- 9: 13.

[70] Mackenzie, Catrina and Peter Ahabyona. 2012. "Elephants in the Garden: Financial and Social Costs of Crop Raiding." Ecological Economics 75: 72-82.

[71] Barnes, R. F. W. (1997). A proposed solution to the Kakum elephant problem. In Facing the storm: five years of research in and around Kakum National Park, Ghana. Proceedings of Kakum Conservation Area Research Colloquium (p. 15_18). 
[72] Bulte EH, Rondeau D. 2005. Why compensating wildlife damages may be bad for conservation. The Journal of Wildlife Management 69: 14-9.

[73] Barua M, Bhagwat SA, Jadhav S. 2013. The hidden dimensions of human-wildlife conflict: health impacts, opportunity and transaction costs. Biological Conservation 157: 309-16.
[74] Muruthi P. 2005. Human wild life conflict: lessons learned from AWF's African heartlands. African Wildlife Federation, Washington, DC, USA.

[75] Ogra, M., Badola, R., 2008. Compensating human-wildlife conflict in protected area communities: ground-level perspectives from Uttarakhand India. Hum. Ecol. 36, 771-729. 


\title{
APPENDIX E: Paper 5
}

\section{Nature conservation policies and practices in Africa: Critical analysis, ideological challenges and strategic vision for protected areas sustainable management}

\author{
Gloriose Umuziranenge $^{\text {ab }}$ and Elysée Ntiranyibagira ${ }^{\text {ac }}$ \\ ${ }^{\text {a }}$ Protestant Institute of Arts and Social Sciences, Rwanda \\ ${ }^{\mathrm{b}} \mathrm{PhD}$ Candidate, University of Bamberg, Germany \\ ${ }^{\mathrm{c}}$ Center for Environmental Research, Training and Expertise for Development in Africa, Rwanda
}

\begin{abstract}
Africa is the most important testing ground for international conservation policies and standards. Their internalization had positive impacts on the extension of protected areas networks. However, these ones are undergoing great degradations that call for a revision of the management systems. The study aimed to: (1) explore and synthesize conservation policies and practices, (2) identify and analyze gaps between standards and field practices and (3) detect bottlenecks and propose alternative strategies for sustainable management. The methodology adopted relies on the interpretative and analytic synthesis of available literature on nature conservation. The results showed that the conservation policies and practices have generated devastating social conflicts and continuous degradation of most of protected areas because of many factors including the lack of management goals, categories and plans. Due to a painful past and an inconsistent present, the management rules have globally failed to maintain original situations at least. The study proved that the poor performances of protected areas management are explained by recurrent conflicts of ideologies, interests and agendas between conservation stakeholders. The vision developed to address the ideological and management challenges relies on a deep reorientation of normative classifications, strategic partnerships and administration, financing and compensation mechanisms and ecotourism development.
\end{abstract}

Keywords: conservation policies, conservation practices, conservation challenges, community centered conservation, sustainable compensation

$$
-185-
$$

本稿の著作権は著者が保持し、クリエイテイブ・コモンズ表示4.0国際シイセンス(CC-BY)下に提供します。 hitps://creativecommons.org/licenses/by/4.0/ deedja 


\section{Introduction}

Today, protected areas and biodiversity represent multiple and important interests for different actors involved in the management of natural resources (Colchester 2003, Giraut et al. 2004, Kaboré 2010 , Kasisi 2012). The diversity of interests, the complexity of actors and the variability of strategies lead to exploitation pressures that threaten biodiversity at all scales. To give an example, biodiversity would have decreased by $30 \%$ globally and by $60 \%$ in the tropics between 1970 and 2008 (WWF/B AD 20 12).

The degradation of the biodiversity has been accompanied by a considerable loss of ecosystem products and services of which $60 \%$ would have deteriorated globally (MEA 2005). These trends would result from several factors, including the predominance of direct socio-economic benefits over the indirect benefits of conservation or ecological services and the impacts of climate change (MEA 2005 , Dudley et al. 2010, FEM 2010).

While the global system of protected areas is one of the most effective solutions for the adaptation to climate change and the mitigation of its effects (Dudley et al. 2010), 89\% of the world's natural systems already suffer from adverse effects of climate change (McCarty 2001). In this context, projected climate changes call for the revision of current assumptions, plans and tools for protected area management (McCarty 2001, Welch 2005, Hopkins et al. 2007). This initiative should lead to fundamental innovations for continuous adaptation of the management goals and systems of degraded or threatened ecosystems.

The in-depth assessment of the appropriateness, relevance and effectiveness of the conservation policies and practices is of particular interest for Africa which represents the continent of conservation per excellence, the testing ground for international conservation policies and the symbol of degradations of protected areas in the world (Rodary 2001, Rodary et al. 2003, Triplet 2009).

Since the colonial period, the creation of African protected areas has systematically been inspired by international conservation policies and standards under the influence of the International Union for the Conservation of Nature (IUCN) and the Trinity of the conservation composed of World Wildlife Fund for Nature (WWF), The Nature Conservancy (TNC) and Conservation International (CI) (Dumoulin and Rodary 2005, Deguignet et al. 2014). The internalization and national ownership of these policies and standards have had largely positive impacts on the extension of national networks of protected areas on the continent. With 2.4 million $\mathrm{km}^{2}$ of protected areas covering $14.7 \%$ of its global area, Africa now has one of the largest networks of protected areas in the world (Deguignet et al. 2014). At regional levels, protected areas cover $10.5 \%$ of West and Central Africa and $14.5 \%$ of Southern and Eastern Africa (Triplet 2009).

At national levels, the coverage of protected areas of African conservation champions such as the Central African Republic, Cameroon and Equatorial Guinea exceeds 20\% of the territory (Triplet 2009, Ndemanou 2012). In addition, while the continent has only $3.3 \%$ of the protected sites in the world, of which $65.6 \%$ are located in Europe, it has the highest proportion of large protected areas which are 
generally national parks because $52 \%$ of them cover more than $100 \mathrm{~km}^{2}$ each (Deguignet et al. 2014). With very few exceptions, such as Rwanda which lost more than $50 \%$ of the original extent of protected areas following decommissioning for the settlement of landless returnees (Rwanyiziri 2009), African countries have continued to expand their protected areas networks since the $1960 \mathrm{~s}$, despite increased demands for agricultural and livestock land, deep land-related tensions and a world trend towards subsidence (Aubertin and Rodary 2008, Ntiranyibagira 2017).

The Aichi Targets and their Strategic Action Plan for the Expansion of the Global Network of Protected Areas by 2020 (CBD 2011, Montpetit 2013) have further boosted the dense African network of protected areas. These dynamics widely praised by the international conservation community, were however been based on the break of the historical human-nature relationships that have long ensured the sustainable management of natural resources through community regulations. Across Africa, the creation, extension and status changes of protected areas have generally been accompanied by forced evictions of local populations (Neumann 1998, Colchester 2003, Descola 2008) and the setting up of military or paramilitary administrations to avoid or limit inevitable pressures coming from the populations driven out from the places.

However, protected areas are continually experiencing increased exploitation pressures and severe degradation in a way that the majority of them would be dangerously endangered or would only exist on paper (Binot 2010). Actual, the population growth, the rising energy demand and the increasing urbanization that are usually blamed for the continued and significant degradation of protected areas (Williams 2000, Raven et al. 2008, Barima 2009, Bamba 2010, Bogaert et al. 2011, WWF2012) do not justify enough observed declines in conservation.

Conservation policies and practices that are largely inspired by the North American ideology of 'protected areas empty or emptied of men' (Calas 2003), which dedicates the total absence or inequalities of access to natural resources for rural populations depending exclusively on the primary sector and natural areas that were historically inhabited and anthropized (Rossi 2000, Colchester 2003), should contribute to these negative trends. Indeed, they are the ones that determine or direct spatialized peripheral socio-economic interactions and therefore, the evolution of protected areas themselves (De Fries et al. 2010, Veyret 2012, Ntiranyibagira et al. 2019).

On one hand, the present study aims to explore the conservation policies and practices from the beginning of normative classifications in the $19^{\text {th }}$ century up to now for critical analysis and the identification of incoherence, contradictions and bottlenecks strangulation that jeopardize the effectiveness of conservation. On the other hand, it will define an ideological re-foundation of conservation strategies that will ensure effective conservation, sustainable use of natural resources and equitable sharing of the benefits of the biodiversity. 


\section{Method of analysis}

The method adopted by the study relies on three stages, namely: (1) a broad exploration and an interpretative synthesis of normative ideological currents, policies and practices of conservation in the world and in Africa, (2) a rigorous and critical analysis of conservation policies and practices in Africa and an identification of inconsistencies, contradictions, bottlenecks and uncertainties that undermine the effectiveness of conservation in Africa; and (3)the definition of altemative ideological options and strategies to ensure the effectiveness and sustainability of conservation on the continent. The study used the following documents and data sources: (i) international conventions and policy documents on nature conservation, (ii) theoretical bibliographic data and scientific publications on nature conservation, and (iii) quantitative and qualitative empirical data from periodic reports of international and national institutions and services specialized in nature conservation.

\section{Evolution of conservation policies}

Historically, it is the mystic and religious considerations that motivated the creation of former protected areas often called 'sacred forests' in indigenous societies of the tropical world and considered as the first protected areas in the world (Ramade 1981). Actually, these are integrated spaces of life, production and cultural expression that are subject to regulated and sustainable community management by means of ancestral customs and specific ritual practices. This is what we name the first time of conservation or the time of man-nature harmony characterized by essential extractions and non-market uses of vital resources.

Protected areas of the modern era appeared in the second half of the $19^{\text {th }}$ century with the creation of the emblematic Yosemite Regional Park and the Yellowstone National Park in the United States of America, respectively in 1864 and in 1872 (Calas 2003, Colchester 2003, Descola 2008). Since that period, the dynamics of creation of protected areas will spread in Europe and irradiate in Africa through European colonization.

On the African continent, it is the Kruger National Park created in South Africa in 1898, the Albert Park known today as the Volcano National Park established between the Democratic Republic of Congo, Rwanda and Uganda in 1925 (IUCN 1999, Pélerinet al. 2011), the Akagera and Nyungwe National Parks established in Rwanda in 1933 (Rwanyiziri 2002) and the Waza National Park established in Cameroon in 1934 which are the first modern protected areas. Here, things take a new direction in the design and purpose of protected areas that are based on the principles of social exclusion and openness to external tourism. Protected areas now respond to the growing need of civilized and urban populations to relax through walks in parks and reserves known for their aesthetic, landscape and tourist qualities (Calas 2003, Colchester 2003, Descola 2008). The founding idea of vision tourism will become the universal driver of conservation policies around the world.

In Africa, specifically, the creation of protected areas focused on natural areas of high tourist 
interest by targeting strategic hunting areas and endemic species that can feed Western world mass tourism (Huxley 1961, Myers et al. 2000, Triplet 2009). As wild animals have become 'things to think about' for rich urban populations rather than 'things to eat' for poor local people (Colchester 2003), it is the savannahs full of wild animals of which the 'charismatic mega fauna' or the 'big five' (Elephants, Rhinoceros, Hippopotamus, Buffalo, Lions) that fit exactly the Western world idea of wilderness, game reserves and national parks (Triplet 2009).

In very rare situations, however, especially in the mountainous areas of Central Africa, the creation of protected areas was primarily a matter of water and soil conservation to fight erosion and water imbalances (Harroy 1949, Rwanyiziri 2009). As a general rule, the creation of African protected areas has been carried out in violation of the interests and dignity of indigenous peoples and has deeply altered traditional ways of life (Calas 2003, Colchester 2003, Descola 2008). Almost everywhere, the process was conducted in pain and desolation because it involved massive and militarized expulsions of local populations (Mengue 2002, Rossi 2002, Rwanyiziri 2002, Colchester 2003, Triplet 2009).

Like the sad experience of some native tribes in the creation of American national parks, several peoples lived very bad moments in different parts of the continent (Turnbull 1987, Constantin 1994, Péron 1995, Rossi 2000, Cochet 2001, Colchester 2003, Aubertin and Rodary 2008, Descola 2008). They were suddenly and violently deprived of free access to key natural resources like crop lands, pastures and water resources, without other survival alternatives (Cochet 2001, Pélerin et al. 2011). In facts, protected areas have become 'food pantries surrounded by hunger' (Sournia 1996) that are permanently exposed to desires of marginalized peripheral populations, ruling elites, private economic operators and even rebel movements (Mengue 2002, Binot 2010, Ntiranyibagira 2017).

This kind of conservation policy based on the American vision of 'uninhabited and uninhabitable protected areas' (Calas 2003) will ideologically mark the establishment and considerable extension of African national networks of protected areas until the 1980s (Myers et al. 2000, Colchester 2003, Raffin 2005, Triplet 2009, Aubertin and Rodary 2008).This is the second time of conservation or the time of the fortress conservation characterized by the prohibition of access and use of protected resources.

In the aftermath of African independences, growing challenges to the continuation and the strengthening of colonial conservation policies will force Westem conservationists to open up an era of international negotiations and develop new arguments to convince skeptical leaders of the interest of the conservation (Sournia 1996, Rossi 2000, Rodary 2001, Rodary et al. 2003). To this end, the African conferences of Arusha (Tanzania) and Algiers (Algeria) held respectively in 1961 and 1968 will have a great impact on the maintenance, the extension and the creation of protected areas in Africa (IUCN 1992, Rwanyiziri 2009). They promoted tourism as a major opportunity for independent governments to increase financial revenues and launch their young economies (Rodary et al. 2003).

This strategy of legitimizing conservation through socio-economic arguments was pursued through the concepts of 'sustainable development' and of 'integration of populations' that appeared with the 
World Conservation Strategy in the 1980s (UICN et al. 1980, Rossi 2000, Veyret 2012). It was reinforced by the concepts of 'Ecosystem Products and Services' and of 'Economy of Ecosystems and Biodiversity' that have been developed in the 2000s (MEA 2005).

The integration between conservation and development is an indirect conservation strategy based on integrated conservation and development projects (ICDPs) that relies mainly on ecotourism development projects in forest areas (Rodary 2001, Nicholls 2004, Binot 2010). It opens the third time of conservation or the time of the participatory approach based on the involvement of local populations in the economic valorization of biodiversity and the redistribution of its benefits. This new conservation approach has gradually emerged as a universal model for the management of protected areas, particularly with the emergence of decentralization policies in Africa during the decade 1980 (Rodary 2001, Adams et al. 2004, Giraut et al. 2004).

In principle, it came to break the North American model of 'uninhabited and uninhabitable parks' which deeply upset the socio-economic and cultural order of the native populations, by considering the objectives of sustainable development and the interests of the local populations (Dumoulin 2005). The major arguments that supported the participatory approach are the following: (1) most of natural ecosystems that were under protection in the colonial period were largely anthropized (Neumann 1998, Rossi 2000); (2) protected areas particularly conserved by native peoples loose less forest than areas under other management systems (Hannah 1992, Rossi 2000, Dumoulin 2005, Nelson and Chomitz 2009), (3) national governments having not enough resources for interventions, local populations with a strong knowledge of biodiversity should be key and alternative actors for better control of the use of natural resources, once motivated and appropriately incentivized (Manuel and Doumenge 2008, Dudley et al. 2010) and (4) the transfer of protected areas and natural resources management to local communities was consistent with the decentralization policies of the 1980s (Dudley et al. 2010, Veyret 2012).

In thinking and practice, three major inflections have marked the participatory approach, namely: (1) the shift from centralized and state governance to local participatory governance, (2) the reconceptualization and refocusing of conservation on the notion of sustainable development and (3) the incorporation of liberal ideas and the use of market forces to finance conservation (Hulme and Murphree 2001, Rodary 2001).

Because of the recurrent financing difficulties, the weak performances or even the failures of participatory management and the continued degradation of protected areas, deep ideological antagonisms still oppose defenders of fortress conservation or complete protection of richest natural areas in biodiversity and advocates of a participatory management approach that reconciles forest conservation and local development (Guéneau and Franck 2004).

The conservationist communities with high financial capacities are openly showing renewed interest for the fortress conservation approach that appears through the definition of priority 
conservation and funding areas such as WWF Ecoregions, CI Biodiversity Hotspots and TNC portfolios (Myers et al. 2000, Olson et al. 2001, Olson and Dinerstein 2002, Wes et al. 2002, Brooks et al. 2006 , Aubertin and Rodary 2008) and the abandonment of participatory management approaches by international financing mechanisms. This is the fourth time of conservation or the time of selective and large-scale fortress conservation.

It is within the framework of the implementation of these global conservation policies that we see emerging regional governance initiatives in the form of politico-technical structures and bodies for the harmonization and the coordination of actions. This is particularly true for transboundary protected areas that are facing national legislative discrepancies and need concerted action frameworks, as single geographic entities. This is the case of the Conference of Ministers of Central African Forests (COMIFAC), the Central African Forest Ecosystems (ECOFAC) and the Protected Areas Network of Central Africa (RAPAC) which were set up with the support of international donors and conservation NGOs (Vives 2001, Doumenge et al. 2015).

In order to overcome the persistent ideological oppositions and the heated and unsuccessful debates it is feeding, a new conservation approach based on the paradigm of 'You should pay for what you want to get' or 'You should pay for conservation and not for conservation related activities' was recently proposed (Ferraro and Kiss 2002, Brown 2003). According to the authors, biodiversity is in danger in developing countries because the material benefits that local populations derive from its destruction far exceed what they expect to gain from its preservation (Ferraro and Simpson 2003).

This still theoretical conception of conservation opens or prefigures what should be the fifth time of conservation or the time of real compensatory merchant conservation. In fact, the raised up question is the direct and indirect financing of conservation. In terms of funding, conservation policies provide two major mechanisms, namely: (1) external subsidies that are defined according to the specific ecological importance of protected areas and (2) fees and duties generated by products and services provided by protected areas (Emerton et al. 2006). This clearly means that income from resource exploitation and ecotourism must be reinvested in the management of protected areas.

Between the two funding sources and in the context of responses to climate change adaptation, Smith (2013) identifies three sources of funding that are: (i) private and public financing, (ii) commercial financing, and (iii) financing under form of subsidies. According to other authors, the national benefits of conserving biodiversity such as the willingness to pay resource users downstream of protected areas and ecotourism are two potential sources of sustainable funding for the cost of the management of protected area networks (Carret and Loyer n.d.).

To achieve efficient and sustainable protected areas management, financial planning and selffinancing mechanisms based on rational exploitation of resources are needed for sound and credible business plans that should attract the private sector and additional resources in the framework of publicprivate partnerships (Landreau 2012). 
In summary, the nature conservation policies in Africa can be divided into five crossed times or periods: (1)from the pre-colonial period to the start of the colonial period in the $19^{\text {th }}$ century, when customary law and community regulations were guiding resources management, (2) from the colonial period to the independence of nations and years 1970-1980 when the fortress conservation was the key word, (3) from the decade 1980 up today when the participative approach is the leading conservation method supported by various tools and instruments, (4) from the 2000 s to present time when policies of sanctuary management of priority and selective regional areas re-emerge from big conservation international NGOs and (5) from years 2002-2003 up today when theoretically emerges a truly merchant and equitable conservation approach that has not yet shaped up.

These conservation policies are inspired by four paradigmatic currents that govern human-nature relationships, namely: (i) the utilitarian or unregulated approach and (ii) the resource-based or regulated approach with management plans and anticipative restrictions that are anthropocentric, (iii) the preservationist or non-use approach that is bio-centric, and (iv) the conservative or limited-use approach that is eco-centric (Rodary et al. 2003, Depraz 2008).

\section{Evolution of practices, tools and management models}

The section shows how the conservation policies have been materialized and reflected into conservation practices and actions. In theory, conservation practices are based on the main characteristics of a protected area that emerge from internationally-agreed normative definitions (CBD 1992, UICN 1994).

As the definition of the $\mathrm{CBD}$ is a minimal statement that results from difficult negotiations and political compromises and is unclear on conservation goals, the characteristics drawn by the UICN definition were considered in the study, namely: (1) the existence of precise geographical boundaries, (2) the existence of a mechanism of recognition and management, and (3) the focus of conservation goals on ecosystem services and cultural values.

In Africa, where national parks are by far the most common type of protected areas, management practices are also based on the attributes of the standardized definition of a national park, namely: (i) a large territory containing one or more ecosystems, (ii) the absence or low level of human occupation and exploitation, (iii) the highly aesthetic and touristic character of sites, habitats and species, and (iv) the restriction of human uses to research, education and recreation (Veyret 2012).

In the framework of fortress conservation, the first two criteria imply large population displacements and serious limitations, and even deprivations of access to protected resources, which are

also applicable to the many natural forest reserves found in Africa. In order to avoid exploitation pressures resulting from peripheral populations driven out of protected areas, these ones are most of the time endowed with militarized or paramilitary administrations, as in the United States of America, where, however, they have only survived until 1916 (Colchester 2003, Rwanyiziri 2009). 
Later, the legislations evolved towards the creation of buffer zones of 500 to $1000 \mathrm{~m}$ large from the limits to compensate socio-economic losses and reduce the anthropogenic pressures of peripheral origin (Mengue 2002, Rwanyiziri 2009, Ntiranyibagira 2017). For that purpose, pilot participatory projects focused on green jobs of the types 'Work for Water', 'Work for Wetlands', 'Food for Work' and 'Wood for Work' were launched around protected areas in Southern Africa before spreading on the continent (Giraut et al. 2004, Granier 2009, Ntiranyibagira 2017).

In the framework of participatory approaches that have been codified and standardized internationally since 2004, through the Working Program on Protected Areas (CDB 2004, Triplet 2009 Montpetit 2013), high levels of protection must be embedded in socially and culturally acceptable processes for fair compensation and fair allocation of costs and benefits (Dudley et al. 2010). To allow minimal access to vital resources and to compensate the limits of ecotourism (Héritier 2007, Dudley 2008, Mahamadou and Boureima 2015), national parks could be dismembered into several protected areas managed under various statutes with adequate zonings combining a wide range of management approaches and categories (IUCN 2006, 2008).

The aim of such strategy is to build a multi-category network of sanctuary protected areas in the center (categories I, II, III) and buffers with less strict protection around (Categories IV, V, VI), while excluding degrading activities such as clear cuts, industrial plantations and unsustainable extractions of resources (Tardif 1999). These areas or zonings with multiple regimes of protection often consist of: (i) zones under integral protection, (ii) reserves for the management of species and habitat, (iii) ecological corridors or bio corridors for the migration of wildlife, and (iv) buffer zones for the compensation of imposed deprivations (IUCN 2006, 2008).

In terms of management practices, protected areas refer to a wide variety of goals, management models and legal statutes (Aubertin et al. 2008). Since the $4^{\text {th }}$ World Congress on Protected Areas held in Caracas (Venezuela) in 1992, the international typology recognizes 7 categories of management goals numbered from Ito VI, that are defined according to the types of use and interventions authorized within protected areas (UICN 1994, Hugh 2000, Héritier 2007, Triplet 2009, Borrini-Feyerabend et al. 2013). It also recognizes two special categories of UNESCO that are 'Biosphere Reserves' that can be modeled on each category of management and 'World Heritage Sites' (Héritier 2007).

In principle, periodical assessments and the analysis of consistency between the management categories and the management practices allow to modify or to adapt the management categories if the actual management methods do not fit to them (IUCN 2008). Similarly, the transformation of existing protected areas into parks and nature reserves should not be used as a pretext for dispossessing the inland or peripheral populations of their lands (IUCN 2008).

In terms of governance or of the structure and the management of the decision-making power (IUCN 2004), the typology decided by the $5^{\text {th }}$ World Congress on Protected Areas held in Durban (South Africa) in 2003 recognizes 4 types of governance that are applicable to each of the 7 management 
categories (Dudley 2008, Dudley et al. 2010). In Africa, protected areas are gradually moving from state governance (Type A) towards co-managed governances (Type B), except in few countries like Rwanda where all the protected areas remain totally under the state governance (Ntiranyibagira 2017). At the same time, we see progressively emerging new protected areas under community governance (Type C) and private governance (Type D).

In terms of participatory management, the legal solutions proposed are of three types, namely: (1) the creation of community protected areas on the initiative and under the direct management of local populations, (2) the financing of income-generating activities with the revenues from protected areas exploitation; and (3) the direct employment of local people in protected areas management (Granier 2009). The sources of financing of income-generating activities include taxes, miscellaneous fees and conservation budgets, in this case royalties on sport hunting concessions in village hunting areas (Granier 2009). Usually, collaboration agreements are in the form of contracts between the public or private manager and the neighboring or peripheral villages (Nouidemona 2004, Granier 2009).

The technical and financial management tools are the management plans (Mackinnon et al. 1990, Chiffaut 2006, Bioret et al. 2009, Benkara 2014), the business plans (Landreau 2012) and the assessment models of management effectiveness (Hocking and Philips 1999, Hockings et al. 2006, UICN 2012). The current models of assessment used for the adaptation of the management modes and judicious allocation of financial resources are the following : (i) 'Pressure, State, Responses' (PSR) (OECD 1993); (ii) 'Driving forces, Pressure, State, Impact, Responses' (DPSIR) (Requier-Desjardins 2012), (iii) the 'Management Effectiveness Tracking Tool for Rapid Assessment and Prioritization of Protected Areas Management' (METT-RAPPAM) (IUCN), (iv) the 'World Commission on Protected Areas Assessment Framework' (IUCN), (v) the 'Protected Areas Benefit Assessment Tool' (PA-BAT) (Dudley et al. 2010), (vi) the African Protected Areas Assessment Tool (APAAT) (Hartley et al. 2007) and (vii) the Protected Areas Trends Assessment and Adaptive Management on the basis of long term Conservation Objectives (PA-TAMCO Analytic Model) (Ntiranyibagira 2019).

After the developments about the conservation policies and practices, we analyze and present hereafter the differences between international standards and actual management practices in order to identify inconsistencies, contradictions and bottlenecks that characterize the conservation sector before proposing our vision for effective conservation and sustainable use of natural resources in Africa.

\section{Critical analysis of the conservation sector in Africa}

\subsection{Travers, implications and setbacks of conservation policies}

In the pre-colonial period, the effective and sustainable management of African natural ecosystems relied on traditional beliefs, ancestral customs, and community-based management mechanisms (Hannah 1992, Mengue 2002). Through exclusionary policies in conservation and religious missions, European colonization and its Westem lobbies have fundamentally disrupted traditional ways of life of 
the people by breaking the historical relationship to nature and the management rules of territories and natural resources (Niang 1990, Hannah 1992, Rossi 2000, Mengue 2002).

By forcing the almost systematic eviction of indigenous peoples from protected areas and the brutal abandonment of ritual practices in many sacred forests (Neumann 1998, Colchester 2003, FAO 2012), the founding myth of conservation policies based on 'a primitive, wild, uninhabited, and uninhabitable nature' where man is a visitor who does not stay long (Colchester 2003) and 'protected areas empty or emptied of men' (Calas 2003) engendered permanent hostility from local populations that lead to increasing illegal exploitations and continued degradation of natural ecosystems that have traditionally been well managed and safeguarded (Rossi 2000, Mengue 2002, Dudley et al. 2010, Ntiranyibagira 2017).

Indeed, the incompatibility between man and nature set by the two pillars of the global conservation policy embodied by the Yellowstone national Park (Colchester 2003, Descola 2008) and the sanctuary management model did not at all fit to historical, socio-economic and cultural realities (Rossi 2000).

First, the myth of 'wilderness' that makes one believe in the virginity of natural ecosystems that man has never changed and the incompatibility of national parks with the permanent human presence is an illusion, if not a nonsense (Rossi 2000, 2002).

Secondly, the establishment of protected areas for the exclusive enjoyment of wealthy visitors from cities and elsewhere, given the touristic qualities of sites and species, did not meet any discemible and relevant demand in African socio-cultural contexts (Ntiranyibagira 2017).

Despite progress in international conservation policies on social openness and participatory management since the $1980 \mathrm{~s}$, African protected areas remain large and largely uninhabited at a time when $70 \%$ to $85 \%$ of the world's protected areas are partly or fully occupied (Dumoulin 2005) and when the world global trend is dominated by small soft-protected areas (Ghimire and Pimbert 1997, Chape et al. 2003).

The recognition and reality of human interventions in the majority of protected areas in the world allow to reject the idea of protection 'against humans' in the absolute as indicated by some critical authors (Carrere and Bravo 2004). They confirm that the fortress conservation of tropical natural areas is a kind of ecological extremism and interference as already stated by other researchers (Rossi 2000). In reality, the dichotomy between 'natural areas' and 'man-made areas' is illusory because all regions of the world have experienced or are experiencing a variable degree of artificialisation (Rossi 2000, Dumoulin 2005). Thus, the abusive pursuit of forced displacements of populations in the creation, extension and changes of status of protected areas and the maintenance of these outside the sphere of socio-economic action are always felt as serious attacks to the rights of local communities over confiscated lands that lead to chronic food crises and hunger (Neumann 1998, Rossi 2000, Cochet 2001, Rodary 2001, Rwanyiziri 2009).

The socio-economic losses suffered by local populations are the more important and damaging than 
the majority of African protected areas are centered on wetlands, large rivers and good agro-pastoral lands (Hughes and Hughes 1992, Ntiranyibagira 2017). The recurrent situations of ecological and touristic priority over socio-economic benefits make African protected areas 'foreign territories' to local communities (Ntiranyibagira 2017) and 'pantries surrounded by hunger' (Sournia 1996) which are only useful for 'foreigners and national elites', especially through tourism activities and revenues (Mengue 2002, Colchester 2003, Triplet 2009).

Actually, African protected areas have become geopolitical instruments for independent states where land dispossession, social exclusion and external appropriation of natural areas and resources replaced in the state domain reinforce poverty and generate significant social conflicts (Neumann 1998, Giraut et al. 2004, Raffin 2005, Depraz 2008, Dudley et al. 2010, Ntiranyibagira 2017).The exception or better, the African rule of 'uninhabited parks and protected areas' proceeds in principle from an imported and imposed governance that perpetuates the colonial conservation policies in opposition to vital interests of local communities (Weigel et al. 2007).

In Africa, the reference of protected areas to wildlife, hunting activities and tourism, which is permanent in conservation philosophy, rhetoric and practices (Mengue 2002, Colchester 2003, Binot 2010 ) generates and maintains multi-faceted stresses among local populations who are constantly confronted to the destruction of crops, properties and human lives by wild animals that feed the Western vision tourism (Rossi 2000, Mengue 2002).

In the absence of relocation and fair and equitable compensation for physical evictions and material destructions, indigenous peoples remain confined to the peripheries of protected areas from where they develop rejection feelings, open hostility and rebellious behaviors (Mengue 2002, Colchester 2003, Triplet 2009, Ntiranyibagira et al. 2019). Protected areas in general and national parks in particular are subject to intense anthropogenic pressure and degradation, more because of social exclusion and inequalities in access to resources than because of rapid population growth and increasing urbanization, contrary to official speeches (UICN-PAPACO 2012, Ntiranyibagira 2017).

Consequently, we realize and note that the substitution of the 'state constraint' to the 'community civic awareness' and of the 'international arbitrariness' to the 'local rationality' creates a permanent struggle of interests between the conservation authorities and local communities who finally and openly fight against the spoliation of their land (Cochet 2001). In this context too, the international framework of participatory management approaches constitutes a paradoxical negation of the traditional knowledge and know-how in the effective management of biodiversity and a major obstacle to the free choice of types and forms of sustainable exploitation of resources.

The incrimination of local communities in the degradation of protected areas by conservationists is also expressed by their strong opposition to the new participatory management categories V and VI from Durban Congress on protected areas that are struggling hard to take place in Africa (Locke and Dearden 2005). Contrary to the fortress conservation management categories I to III favored by 
conservationists, donors and national governments themselves, management categories IV to VI where human interventions are authorized are rare in Africa where states still play a central role in the regulation and legislation of participatory management (Binot 2010, UICN-PACO 2012, Ntiranyibagira 2017).

At the same time, state mistrust of groups of citizens escaping or being beyond its control severely limits achievements in community and private managed protected areas (Granier 2009). Through the relegation of social concerns in decision-making (Mac Chapin 2004), regional and selective priority conservation policies also take the opposite view of the participative model that has been professed (Balmford et al. 2002, Wilson et al. 2006, Manuel and Doumenge 2008).In fact, there is also a lack of consensus on which human activities may be permitted in national parks in the case of occupation and use (Western and Wright 1994, Oates 1999, Hulme and Murphree 2001, Terborgh et al. 2002) that paradoxically prevents any activity.

In the case of political conflict and instability, social exclusion often serves as a pretext for uncontrolled occupation and significant destruction of protected areas by people fleeing war or seeking for new agricultural land (Kanyamibwa 1998, Katembo 2011).Because they are uninhabited, protected areas often constitute bastions, sanctuaries and rear bases for militias, guerrillas and rebellions that make them their guards, their training areas and their hiding places (Katembo 2011).

This dilemma of the conservation in Africa is accompanied by instability in laws, statutes and field practices that increases frustration, stimulates social conflicts and further exposes protected areas to degradation by strategically and usefully repositioning actors at each new conservation initiative (Ntiranyibagira 2017).This is more evident in countries with limited resources where the fortress conservation approach is the most inefficient (Raven et al. 2008, Honloukou 2014).

\subsection{Inadequate, poorly mastered and inefficient management systems}

As already mentioned, the management of African protected areas is based on imported governance characterized by the ex-cathedra adoption of the principles and objectives of protection decided at international level but which are unfortunately disconnected from the traditional mechanisms of management of shared natural resources (Weigel et al. 2007). This mode of governance articulated on a system of co-management of protected areas between States, conservation NGOs and/or international donors promotes the ecological interest of protected areas against the socio-economic concerns of local populations which are often poor, heterogeneous and politically weak (Binot 2010, Ntiranyibagira 2017).

In most countries, the agencies responsible for the implementation of this kind of governance are usually associated with dominant ministerial structures and do not have the necessary administrative and financial autonomy to take initiatives and to achieve a management effectiveness that should be comparable to that of autonomous or semi-autonomous structures that have their own budgets and a sufficient administrative autonomy (Rwanyiziri 2009, Triplet 2009). 
Thus, African protected areas remain largely managed according to a centralized, authoritarian and bureaucratic vision of planned resource management (Giraut et al. 2004). In general, the laws do not set management goals, management plans and boundaries of protected areas of which some would only exist on paper and would be dangerously threatened (Triplet 2009, Binot 2010, Benkara 2014).

In this respect, it is estimated that $85 \%$ of African protected areas have no management categories, goals and plans (Deguignet et al. 2014). In cases where management plans exist, they are rarely validated, applied, evaluated and updated (IUCN-PAPACO 2012). In the majority of protected areas, these fundamental deficiencies are aggravated by four major physical constraints, namely: (1) the absence of precise boundaries that are materialized on the ground, (2) the absence of buffer zones defined by the theoretical concentric structure of protected areas for the absorption of peripheral social conflicts (Mengue 2002), (3) the asymmetric and irregular shapes that increase linear exposure and strengthen physical vulnerability to peripheral pressure (Ntiranyibagira et al. 2019) and (4) the geographic dispersion that often makes it difficult or impossible to build connective networks for easy biological migrations (Bonnin 2008, Ntiranyibagira 2017).

On the African continent, there are generally significant gaps between conservationist rhetoric and actual management practices that remain largely unchanged, despite the good intentions of official policies and speeches (Binot 2010, Ntiranyibagira 2017). These differences are expressed by sometimes glaring discrepancies between the management categories and the actual modes of management. For example, occupations and activities of authorized exploitations of natural resources corresponding to management category VI are often carried out in protected areas of management category IV (UICN 2014, Ntiranyibagira 2017). In addition, management categories often serve as pretexts to dispossess people of their lands when they are only indicative (IUCN 2008).

In this respect, national parks are still managed according to the guidelines or the international and normative definition of category II, which excludes any human activity other than research, education and tourism (IUCN 1994, 2008, Manuel and Doumenge 2008). As an illustration, the creation of national parks and the transformation of existing protected areas into national parks are continuously and still leading to population expulsions (Ntiranyibagira 2017). With regard to the accompanying measures of participatory approaches, also the reasoned zoning of national parks and the creation of multi-category networks for a minimal exploitation of resources are rare, so that the participatory management activities organized in protected areas of category II are conducted in violation of the normative management criteria.

In other countries, type A or state governance is abusively assimilated to co-management or participatory management systems while it is heavily administered and overseen by central governments. From another angle, the lack or insufficiency of reliable research and databases jeopardizes the development and updating of conservation goals and management plans; which mortgages the necessary evolution and the efficiency of the management systems (Sambou 2004, UICN-PAPACO 2012). In 
many protected areas, the updating of the management plans does not rely on in-depth assessments of global evolutionary trends, due to the lack of appropriate technical tools and of human and financial resources (Dudley and Stolton 1999, Mengue 2002, Ntiranyibagira 2019).

\subsection{Limitations and weaknesses of ecotourism}

Since eco-tourism was presented as the great socio-economic argument that could justify and legitimize the nature conservation in Africa, it has got very little impact in many countries (Dumoulin 2005, Binot 2010, Ntiranyibagira 2017). Despite the spectacular evolution of nature, safari and culture tourism during the $2000 \mathrm{~s}$, the continent remains one of the world's least popular tourist destinations.

In 2011, Africa counted for only $5.1 \%$ of the world's international tourist population. In general, the creation of local wealth based on tourism shows huge disparities between countries and regions. While tourism remains weak or quite inexistent in many protected areas in Western and Central Frenchspeaking Africa, it is successful in a few English-speaking Eastem and Southern African states wellknown for their protected areas (Triplet 2009). Beyond the obvious negative influence of structural, organizational and strategic factors, political crises and instability explain the poor tourism performances of protected areas in some countries, particularly in Central Africa (Ntiranyibagira 2017).

According to the World Bank, tourism receipts contribute only for $8.9 \%$ of Gross Domestic Product in East Africa; $7.2 \%$ in North Africa; $5.6 \%$ in West Africa; $3.9 \%$ in Southern Africa and $1 \%$ in Central Africa. The revenues from the economic valuation of protected areas and tourism are mostly distributed on a macro-economic scale between foreign or national private companies, park management services and states (Landreau 2012). They often remain an exchange between foreign tourists and external operators; so that the benefits generated by the tourism valorization go largely to the private sector (Dumoulin 2005, Doumenge et al. 2015).

In the few countries where ecotourism and the share of tourism revenue are some successes, the tourist income is administered according to public rules and directed towards traditional development activities like the construction of schools and health structures that do not compensate the direct socioeconomic losses and needs of local populations (Ntiranyibagira 2017, Umuziranenge 2019a).Moreover, official statements on the socio-economic benefits of tourism only announce the turnover generated by ecotourism activities and the usual proportion of 5 to $10 \%$ which is often offered to local communities to finance common development activities (Doumenge et al. 2015, Umuziranenge 2019a).Nothing is said about operating expenses, related tourism revenues, actual net profit, and the distribution of profits between stakeholders that is defined without the involvement of local communities. This obviously raises the problem of relevance of participation, transparency in management, equity in benefit sharing and environmental justice, in short (Umuziranenge 2019b).

In most cases, local communities involved in ecotourism projects would receive only a small share of the benefits and would depend only on other activities that are sometimes very predatory for their 
livelihood (Oates 1999, Nicholls 2004, Dumoulin 2005, Aubertin and Rodary 2008, Doumengeet al. 2015). Except the sale of some handcraft products and low-paid jobs by local staff such as tour guides, tourist baggage handlers, maids in hotels and car drivers, the economic benefits of tourism are derisory in Africa (Aubertin and Rodary 2008, Doumenge et al. 2015, Ntiranyibagira 2017).

In many countries, the low income from ecotourism and wildlife related commercial activities and their retrocession to central services exclude or limit the socio-economic impacts on local populations and protected areas self-financing (Triplet 2009, Ntiranyibagira 2017).

The gradual decreasing of international funding, the weak national investments in nature conservation, the persistent human wildlife conflicts, and the lack of fair and equitable compensation for damages (Colchester 2003, Webber et al. 2007, Wanyingi 2016, Ogunjobi et al. 2018), persistent insecurity and ongoing protected areas degradation are factors that do not promote positive tourism development in Africa. Indeed, well financed, secured and managed protected areas have a more interesting development of tourism and touristic incomes.

\subsection{Inefficacity and weak performances of participatory management}

If participatory management seeks to reintegrate local populations into the management of protected areas for the re-appropriation of lost profits, it is true that the initiative and the power of the organization of space and activities are still beyond their control (Niang 1990, Wood et al. 2000). Actually, beyond the legislation that speaks about the interests of the populations, the management of many protected areas still remains under the protectionism approach for the capture of external financings that are more and more conditioned to the fortress conservation.

In participatory partnerships for conservation, states still play a central role as it concentrates the ownership and the responsibility for the management of protected areas under co-management status (UICN-PACO 2012). This is the case in West Africa where the control of protected areas is often subject to conflicts between states and local communities (UICN-PACO 2012).

Most often, local populations are only auxiliaries or relays for conservation who serve to diffuse unilateral management decisions, without having any prerogative (Binot and Joiris 2007, Binot 2010, Laslaz 2010). Participation has simply become a way of legitimizing and validating decisions already made by protected area managers, in complete contradiction with theoretical principles of this decentralized and democratic management approach (Borrini-Feyerabend et al. 2000, Joliveau2001, Ribot and Peluso 2003, Bioret et al. 2009, Laslaz 2010, Veyret 2012, Borrini-Feyerabend et al. 2013). In its current form, participatory management seems to involve local people to protect protected areas 'against themselves' ultimately (Ntiranyibagira 2017). Finally, the real commitment of local populations and the community partnership for conservation are still weak (Binot 2010, Ntiranyibagira 2017). Despite the old introductions of the participatory paradigm and the legislative advances in this field (Hulme and Murphree 2001, Guéneau and Franck 2004), the current management methods remain 
dominated by centralized and coercive practices (Brown 2003, FEM 2010, UICN-PACO 2012). This often appears through the determination of the methods for the resource exploitation, the definition of the tourism revenue sharing mechanisms and the choice of the community development investments that are, in any case, the responsibility of states, regardless of the presence of protected areas.

Generally, participatory management regulations are only articulated on good principles that are part of the classic rhetoric of conservation because states often lack the means for the implementation of their policies (Binot 2010). While participatory management recognizes the land rights of indigenous peoples and the abandonment of forced displacements in the establishment and the management of protected areas (CDB 1992), the violation of these rights has continued in the great majority of protected areas (Nelson and Chomitz 2001, Manuel and Doumenge 2008).

When through the decentralization processes, certain transfers of powers and responsibilities become effective; they are quickly recovered by powerful groups of interests for their own benefit (Binot 2010). This means that the decentralization often generates a new centralization at a lower level, which perpetuates the same imbalanced powers, the same democratic deficits and the same negative effects (Ntiranyibagira 2017). The recurrent advisory role of local populations in the protected areas management does not yet allow to reverse trends and to engage a fruitful participation (BorriniFeyerabend et al. 2000, Binot 2010, Laslaz 2010, Borrini-Feyerabend et al. 2013).

As a result, the social impact of conservation projects 'for, with and by' communities based on direct and controlled exploitation of resources and the financing of income-generating activities by protected areas is insignificant in the majority of protected areas (Compagnon and Constantin 2000, Triplet 2009, Binot 2010, Bonnin and Rodary 2012). In addition to the very limited impacts of participatory management actions, participatory management programs are fundamentally unfair for two main reasons. Firstly, farmers pay dearly in work the access to previously owned natural resources through common participatory projects based on work against resources (Granier 2009, Ntiranyibagira 2017). Secondly, the real benefits from the exploitation of resources are largely captured by elites (Doumenge et al. 2015)

Actually, socio-economic opportunities related to participatory management are derisory with regard to local communities. They rely only on few local jobs of eco-guards, trackers and lodge staff, limited extraction of some non-timber forest products and little income-generating activities. In fact, the low level of operating revenues from protected areas and the retrocession of a large part to central conservation services do not allow to finance truly income-generating activities and to create consistent jobs for local populations (Granier 2009, Ntiranyibagira et al. 2017).

In summary, the main factors that limit the effectiveness of participatory management are: (1) internal contradictions and conflicts of interest between stakeholders that are generally heterogeneous (Agrawal and Gibbson 1999, Binot 2010), (2) the current incompatibility between the exploitation of resources and conservation goals due to lack of prior or accompanying research (Ntiranyibagira 2017), 
(3) the frustrating position of landless people who often serve as workforce for wealthy and powerful individuals in participatory management projects (Binot 2010), (4) the highly restrictive conditions for the sustainable use of natural resources through various mechanisms of regulation of extractions and the high taxation of products (UICN et al. 1980, Ntiranyibagira 2017), (5) the anecdotal and symbolic nature of local job opportunities and access to resources in comparison with the immense socio-economic needs of peripheral populations (Granier 2009, IUCN-PACO 2011), (6) the weaknesses of net operating revenues compared to the great profitability of non-sustainable management activities (Ferraro and Simpson 2003, Nicholls 2004, Binot and Joiris 2007, Binot 2010, Bonnin and Rodary 2012), (7) the inability of participatory management programs to respond to external forces that threaten protected areas such as the attractiveness of migrants, the degradation induced by successful projects and the short duration of the projects (Soule and Terborgh 1999), (8) the determining role of territorial administrations in the creation and the management of the abusively named communitarian protected areas (Granier 2009), (9) the underfunding of participatory management projects for protected areas whose major threats come from powerful and external economic interests and projects (Guéneau and Franck 2004) and (10) the incoherence between common participatory management and the principles of conservation marketing, particularly with regard to the socio-economic equity and the maximalist trade profits (Koontz 2008).

\subsection{Funding structural crises, prioritization and selectivity}

In Africa, the conservation sector is characterized by low budgets and chronic underfunding that hinder the effectiveness of the protected areas management. With annual average budgets reaching hardly 5 US\$ /ha/year (Carret and Loyer n.d., Ntiranyibagira 2017), it remains one of the neglected sectors in African economies despite the enormous interests that it represents and the challenges it faces. Despite the generalized insufficiency of conservation budgets, huge disparities exist between countries. National conservation budgets range from a few thousand to a few million US dollars (WCMC 1992, Ntiranyibagira 2017).

Studies have shown that most African countries devote less than $20 \%$ of the amount considered as appropriate to national park management (WCMC 1992, IUCN 1999, Colchester 2003). They indicate that the investment per $\mathrm{km}^{2}$ in United States of America national parks is six times higher than in Central Africa, despite a much lower biodiversity (Guéneau and Franck 2004).The weakness of national conservation budgets, the inability of protected areas to generate enough revenue through tourism and exploitation of resource, the return of most of the operating revenue to central services and the high dependence on external financings that becomes uncertain explain the ineffectiveness and the inefficiency of conservation policies (James 1999, Mengue 2002, Guéneauand Franck 2004).

In African countries, the cuts of budget that are common to protected areas are unfortunately

increasing in times of political conflicts and crisis; precisely when they face widespread destructive 
assaults (James 1999, Hugh 2000, Dumoulin 2005, Ntiranyibagira 2017). This politico-financial paradox is prejudicial to protected areas and conservation because the times and conditions of high vulnerability occur simultaneously. The low capacity for internal and external financial mobilization which is common to many protected areas results from the lack of financial planning and the multiple challenges of tourism that are driven by conflicting interests (Dumoulin 2005, Landreau 2012).

Unlike Western countries where protected areas operate on the basis of state budgets and the reinvestment of revenues from private exploitation through state representatives at the central and decentralized levels (James 1999).

The extension of protected areas networks and the cuts of budget in state subsidies are leading many protected areas in huge financial difficulties (Hugh 2000, Deguignet et al. 2014), as much as international financial donors like the Global Environmental Facility (GEF) and the Trinity of Conservation (WWF, TNC, CI) allocate the available funds by prioritizing the so-called priority protected areas to secure their financing outside state frameworks (Bonnin and Rodary 2012).

Since Rio Conference in 1992, intemational funding is focused on the differential and preferential ecological interest of protected areas and countries (IUCN 1999). Today, international conservationist currents and lobbies exchange funds against the maintenance and the multiplication of protected areas with sanctuary management. In fact, only the major international conservation NGOs are able to implement the new regional policies of priority conservation zones because of their prohibitive costs that are unaffordable to many other actors (Aubertin and Rodary 2008).

The global triage policy in conservation that favors areas of maximum diversity and reduced vulnerability has limited or canceled the funding of many protected areas of lower priority with regard to the great threatens they are facing (Colchester 2003).

This selective policy was reinforced with the Digital Observatory of Protected areas (DOPA) initiative that manages protected areas larger than $100 \mathrm{~km}^{2}$, mainly in Africa (Dubois et al. 2015). Under this initiative, the allocation of funds gives priority to protected areas requiring greater attention and countries with the greatest potential in relation to agreed or decided global conservation goals, including the most recent Aichi conservation objectives (CDB 2010).

At the same time, the extension of African protected areas networks and the affirmation of participatory management approaches lead to a reduction in the availability of international funding on which most of countries rely, including for the funding of regional conservation institutions that are gradually emerging in Africa (Doumenge et al. 2015).

The GEF which is the largest international mechanism for conservation funding, provides only punctual and unforeseeable contributions due to equally timely contributions from its financial supports (Mengue 2002, Dumoulin 2005). In addition to being unpredictable, external funding often only covers protected areas research and management activities, while being limited by the duration of specific projects (Mengue 2002, Ntiranyibagira 2017). In this context of international financial crisis; the high 
dependence of African protected areas on external financing and the enormous selectivity of zones and protected areas that are eligible to financings, the question of financial planning, self-financing and empowerment becomes a particular concern (Dumoulin 2005).

In the absence of sufficient budgets and financial autonomy, national conservation organizations are unable to conserve funds raised in protected areas (James 1999, Mengue 2002). They are also not encouraged to develop revenue-generating programs that they are obliged to hand over to the public treasury, or to cooperate with the private sector. Under these conditions, participatory management projects receive only small conservation grants for emergency management and short-term actions, especially in protected areas of categories IV and VI (UICN-PAPACO 2012, Agence Française de Développement 2014).

\section{Bottlenecks and challenges for conservation}

The in-depth critical analysis of the governance systems of the conservation in Africa shown that the ongoing conditions of the protected areas management are responsible for a systematic, increasing and continuous degradation that makes many protected areas open agricultural and agropastoral parks under a protection status that only exist on paper. It revealed that the major bottlenecks and challenges to be addressed are the following: (1) the still dominant model of uninhabited protected areas in a context of high population densities and deep land tensions, (2) the lack of compensation and relocation of populations expelled from protected areas that leads to the concentration of these people at the immediate peripheries of protected areas, (3) the absence, narrowness or non-functionality of buffer zones for a minimum socio-economic compensation of imposed deprivations, (4) the persistence of centralized and coercive management methods, insufficient guarding staff and increased illegal agropastoral pressures, (5) the chronic internal underfunding and unreliable external financing, (6) the quite inexistent domestic tourism, and the limited socio-economic benefits of ecotourism and of activities of exploitation of resources, (7) a lack of data, tools and indicators for planning and management that lead to sight navigations and trials and errors in management, (8) democratic and managerial deficits in participatory management, and unequal distribution of the conservation benefits in the disfavor of local populations, (9) the persistence of human-wildlife conflicts and the lack of effective and equitable economic compensation systems and (10) the instability of conservation statutes and the proliferation of concessions of economic exploitation for the benefit of external private investors.

The management challenges result from a certain number of interferences, incoherence, contradictions, ambiguities and misunderstandings that the new vision for a fair and sustainable conservation will address.

Firstly, the primacy of external institutions and actors in the choice of the main areas to be protected or kept under protection, the definition of conservation policies and practices, the financing of protected areas and the growth of tourism makes conservation an interested external business that is often 
disconnected from basic socio-economic concerns and needs of local populations. Secondly, the world conservation enterprise conveys now a fundamental contradiction or hypocrisy that recognizes and theoretically promotes the interests and know-how of local people, while effectively making them passive and marginalized partners in accessing the benefits of the conversation. Thirdly, the coming in of private investors devotes capitalist practices that further marginalize local communities in management and fair access to conservation benefits. Fourthly, the easy neo-Malthusian argument about the negative impact of the population growth on the exploitation of natural resources obscures the social exclusion and inequalities of access to natural resources as the main causes of exploitation pressure and degradation. Fifthly, the current coverage of illegal activities and demands by local governments and political elites for political purposes is frustrating protected areas managers and deserving the cause of conservation. Sixthly, the lucrative illegal or legal exploitations of protected areas by wealthy and powerful individuals using poor local populations as labor deconstruct the universal interests and benefits of conservation. In fact, African protected areas are more threatened by powerful economic interests carried by large agribusiness projects than by the survival resources extractions of local populations. Seventhly, the quasi-generalized democratic deficits in African countries and the persistence of top down approaches do not allow a truly democratic management of natural resources required by participatory approaches.

\section{Vision and options for sustainable conservation}

The vision and options proposed to address management challenges and ensure broadly inclusive, mutually beneficial and sustainable conservation of protected areas in Africa are built on the key results emerging from the critical analysis of conservation policies and practices namely, (i) conservation involves multiple actors with conflicting interests, unbalanced powers and unequal means of intervention, (ii) community-based and traditional non-market management of natural resources are the most effective and sustainable forms of conservation, (iii) the substitution of 'man in nature' by 'man and nature' made possible by the strengthening of fortress approach and the weaknesses of participatory approaches are the major ingredient of the hostility of populations and the main driver of degrading pressures, (iv) the establishment of many large-scale protected areas maintained outside the sphere of socio-economic action contribute to create stresses and to reinforce illegal pressures, (v) the lack of fair, equitable and timely compensation for expropriations and deprivations still justifies illegal loggings and degradation of protected areas, (vi) the international and national benefits of ecosystem services provided by protected areas inevitably result from direct losses of benefits for local communities that are not at all or not enough compensated, (vii) the ineffectiveness of the fortress conservation approach and the low efficiency of participatory programs are based on many factors that are external to local communities, (viii) the decentralization in natural resources management actually leads to a low-level centralization that perpetuates the state's diktat and the imbalanced powers in disfavor of local 
populations, (ix) the interest of conservation for local populations and national governments is generally perceived through direct socio-economic benefits and financial support or income, and (x) the achievement of the Aichi goals for the extension of protected areas networks is compromised by deep land tensions, large-scale community opposition and significant financing difficulties.

The options proposed to achieve sustainable conservation are based on eight fundamental principles:(1) the effectiveness of conservation has to be thought and assessed as a balance between the achievement of global ecological and economic goals and the satisfaction of vital socio-economic needs of local communities, (2) sustainable conservation approaches should guaranty a minimum access to vital natural resources or altemative fair, equitable and sustainable socio-economic compensation in the case of exceptional sanctuary conservation, (3) efficient conservation approaches have to rely on community commitment and responsibility for conservation instead of individual or associative involvements of persons considered in local communities, (4) genuine and active participation of local communities in management mechanisms and conservation benefit sharing have to rely on broadly representative and democratic bases, (5) decision making and powers involved in conservation partnerships have to be rebalanced in favor of local communities through a democratic and sufficient representation of communities in administrative and management bodies, (6) the management bodies have to be administratively and financially autonomous for each protected area, (7) the sustainable financing of conservation and the efficiency of conservation have to rely mainly on the development of domestic tourism and on internal resources, and (8) the financing of socio-economic compensations and continuous protected areas management have to be based on international and national citizen awareness and solidarity for the safeguarding of ecosystem services which are also of universal interests.

The vision defends the reproduction, the modernization and multi-level financing of communitybased conservation known to be a successful approach of conservation, while adapting it to current realities. At ideological, strategic and operational levels, the new options are as follows: (i) the replacement of the concept of protected areas that conveys a strongly homophobic connotation by the more neutral but evocative concept of 'biodiversity conservation areas', (ii) the systematic and prior evaluation of the management of existing protected areas for the characterization of spatial transformations and landscape dynamics, the identification of the global evolutionary trends and their classification taking into account the degree of threats and degradation, (iii) the transformation of highly degraded or threatened protected areas into natural communitarian landscapes to be managed according to the principles of agro-ecology and to concerted conventions of conservation management, (iv) the priority allocation of financial savings, available resources and funding mobilized to the management of protected areas with positive evolutionary trends or enough stability for the development of peripheral sustainable projects and ecologically connective networks, (v) the focus of conservation on the paradigms of 'protection through production' and 'production through protection' based on the development of peripheral compensatory projects oriented towards agro-pastoral modemization and 
intensification and energy substitutions thanks to universal compensatory funds and socio-economic benefits of conservation, (vi) the delimitation of peripheral socio-economic dependent zones and the democratic establishment of autonomous community councils representing different groups of interests for protected areas active management, (vii) the establishment of state-local communities-private joint shareholdings and autonomous protected area boards of directors composed of the representatives of stakeholders and notably intended to vote programs and operating budgets, to define periodic extractions of resources that are essential for vital socio-economic uses, to adopt accounts and management reports, to decide on the allocation of operating profits, to endorse community development projects that support conservation and to update management objectives, plans and tools, (viii) the establishment of national environmental pilgrimages for the development of patriotic mass tourism relying on the principle of proximity, community-based logistics and affordable tariffs, and (ix) the establishment of universal national and international funds to finance compensatory projects and actions for short and long terms socio-economic deprivations and damages by wild animals.

\section{Conclusion}

The critical retrospective analysis of policies and practices of nature conservation in Africa showed that they are characterized by a certain number of incoherence, inconsistencies, contradictions and ambiguities that lead to inefficient management and serious challenges for sustainable conservation of protected areas. It revealed that the governance systems are creating management conditions that favor uncontrolled exploitations and almost systematic and continuous degradation of protected areas of which the majority have become open agro-pastoral parks, under legal protection status. Since the colonial period, the conservation governance has globally failed to achieve and maintain a minimum of efficiency in the management of protected areas.

The study showed that poor performance and continuous degradation of protected areas are mainly justified by conflicts of ideologies, interests, and agendas between multiple actors having imbalanced means of intervention, positions and powers. Beyond the financing difficulties and obvious technical and managerial gaps, the main challenges that the sector of conservation is facing are the important role played by external bodies and actors, democratic deficits and the persistence of centralized approaches at the national level, the ambiguity of territorial administrations and political elites in their relations with local communities regarding conservation actions, the interferences and capitalist activities of external economic operators, the weakness of the participatory management approaches and the marginalization of the local communities in protected areas management and access to the socio-economic benefits of the conservation.

The vision proposed to address the conservation challenges considers and evaluates the conservation effectiveness as a balance between the satisfaction of vital non-market community socioeconomic needs and the achievement of global ecological and economic goals through compensatory 
market preservation. Its starting point is the preliminary assessment of the evolutionary trends of protected areas for an in depth rethinking and restructuration of the conservation statutes and the management categories, the conservation partnerships, the modes of administration and management and the financing modalities. It fundamentally refocuses conservation on community interests, commitment, responsibility and participation, a rebalancing of forces and powers in the partnerships, the institution of State-Local communities-Private joint shareholdings, the universal solidarity financing of socio-economic compensations and permanent management of protected areas and equitable sharing of socio-economic benefits. In practice, it involves a well thought revision and the improvement of the management based on strategic decommissioning and reclassifications of existing protected areas, and the extensions of protected areas networks centered on local community.

\section{Acknowledgement}

The authors thank the Tokyo University of Foreign Studies in Japan, the Protestant Institute of Arts and Social Sciences in Rwanda, the University of Bamberg in Germany and the Center for Environmental Research, Training and Expertise for Development in Africa that cooperated to the research by providing key references and contributing to the literature review and analysis.

\section{References}

Adams, M.A., R. Aveling, and D. Brockington 2004. 'Biodiversity conservation and the eradication of poverty'. Science 306 (5699): 1146-1149.

Agence Française de Développement 2014. Les aires protégées au service du développement durable.

Agrawal, A. and C.C. Gibson 1999. Enchantment and Disenchantment: 'The role of community in natural resource conservation'. World Development 27(4): 629-649.

Aubertin, C. and E. Rodary 2008. 'Aires protégées, espaces durables?' IRD.

Balmford, A., A. Bruner, P. Cooper, et al. 2002. 'Economic reasons for conserving wild nature'. Science 297: 950-953. doi: 10.1126/science.1073947.

Bamba, I. 2010. 'Anthropisation et dynamique spatio-temporelle de paysages forestiers en République Démocratique du Congo'. Thèse de Doctorat, Université Libre de Bruxelles.

Barima, S.S.Y. 2009. 'Dynamique, fragmentation et diversité végétale des paysages forestiers en milieux de transition forêt-savane dans le Département de Tanda (Côte d'Ivoire)'. Thèse de Doctorat, Université Libre de Bruxelles.

Benkara, E. 2014. Tableau de bord et Réserves naturelles. Mise en place d'une démarche pour évaluer l'efficacité de la gestion du patrimoine naturel de la Réserve Naturelle de la baie de Saint-Brieuc (France). Rapport final-version du 27.02. 2014. Vivarmor Nature, Agence des Aires Marines 
Protégées.

Binot, A. 2010. 'La Conservation de la nature en Afrique Centrale. Entre théories et pratiques. Des espaces protégés à géométrie variable'. Thèse de Doctorat, Université Paris I Panthéon-Sorbonne.

Binot, A. and D.V. Joiris 2007. Règles d'accès et gestion des ressources pour les acteurs des périphéries d'aires protégées. Vertigo - la revue électronique en sciences de l'environnement. Hors-série 4 | novembre 2007, mis en ligne le 11 novembre 2007. <http://vertigo.revues.org/759; doi: 10.4000/vertigo.759 / Accessed on 21 April 2019>

Bioret, F., R. Esteve and A. Sturbois 2009. Dictionnaire de la protection de la nature. Presses Universitaires de Rennes.

Bogaert, J., Y.S.S. Barima, and W.M.L. Iyongo 2011. 'Forest fragmentation: causes, ecological impacts and implications for landscape management'. In Landscape Ecology in Forest Management and Conservation: Challenges and Solutions for Global Change. Eds. C. Li, R. Lafortezza, and J. Chen, New York: HEP-Springer, pp.273-296.

Bonnin, M. 2008. Les corridors écologiques: Vers un troisième temps du droit de la conservation de la nature?' Paris: L'Harmattan.

Bonnin, M. and E. Rodary 2012. 'L'influence des services écosystémiques sur les aires protégées: premiers éléments de réflexion'. Programme Serena, Document de travail 2012-02.

Borrini-Feyerabend, G., M.T. Farvar, J.C. Nguinguiri, et al. 2000. 'La gestion participative des ressources naturelles: Organisation, négociation et apprentissage par 1'action'. GTZ et IUCN, KasparekVerlag, Heidelberg.

Borrini-Feyerabend, G., N. Dudley, T. Jaeger, et al. 2013. Governance of Protected Areas: From Understanding to Action. Best Practice Protected Area Guidelines Series No. 20. Gland: IUCN.

Brooks, T.M., R.A. Mittermeier, G.A.B Da Fonseca, et al. 2006. 'Global biodiversity conservation priorities'. Science 313: 58-61.

Brown, K. 2003. 'Three challenges for a real people-centred conservation'. Global Ecology and Biogeography 12: 89-92.

Calas, B. 2003. 'Quel est le véritable patrimoine des parcs animaliers est-africains?' GéoProdig, portail d'information géographique. < http://geoprodig.cnrs.fr/items/show/197672.>

Carrere, R. and E. Bravo 2004. 'Protected areas: Protected against whom?' Oilwatch \& WRM.

Carret, J-C. and D. Loyer n.d. 'Comment financer durablement le réseau d'aires protégées terrestres à Madagascar?' Apport de l'analyse économique. Banque Mondiale, Agence Française de Développement.

Convention on Biological Diversity 2011. 'Protected areas: Progress in the implementation of the program of work and achievement of Aichi Biodiversity Target 11'. UNEP/CBD/COP/11/26.

Convention sur la diversité biologique 1992. Convention sur la diversité biologique. Rio de Janeiro, ONU. 
2004. 'Programme de travail sur les aires protégées'. Montréal: Secrétariat de la convention sur la diversité biologique.

2010. 'Perspectives mondiales de la diversité biologique'. Troisième Edition, Montréal.

Chape, S., S. Blyth, L. Fish, P. Fox, and M. Spalding 2003. 2003 United Nations List of Protected Areas. Cambridge: IUCN Publication Service Unit.

Chiffaut, A. 2006. Guide méthodologique des plans de gestion de réserves naturelles. MEED/ATEN, Cahier technique $\mathrm{N}^{\circ} 79$.

Cochet, H. 2001. Crises et révolutions agricoles au Burundi. Paris: Editions Karthala/INAPG.

Colchester, M. 2003. Nature sauvage, nature sauvée? Peuples autochtones, aires protégées et consenvation de la biodiversité. Mouvement mondial pour les forêts tropicales, Forest Peoples Programme.

Compagnon, D. and F. Constantin (Eds.) 2000. Administrer l'environnement en Afrique. Paris/Nairobi: Karthala/IFRA.

Constantin, F. 1994. 'L'homme et la nature: une gestion à réinventer?' Politique africaine 53: 3-10.

De Fries, R., K.K. Krithi, and S. Pareeth 2010. 'Interactions between protected areas and their surroundings in human-dominated tropical landscapes'. Biological Conservation 143(12): 28702880.

Deguignet, M., D. Jufe-Bignoli, J. Harrison, et al. 2014. Liste des Nations Unies des aires protégées 2014. Cambridge: UNEP-WCMC.

Depraz, S. 2008. Géographie des espaces naturels protégés. Genèse, principes et enjeux territoriaux. Paris: Ammand Colin.

Descola, P. 2008. A qui appartient la nature? Texte paru dans laviedesidees.

Doumenge, C., F. Palla, P. Scholte, F. Hiol, and A. Larzillière 2015. Aires protégées d'Afrique centrale: État 2015. Kinshasa \& Yaoundé: OFAC.

Dubois, G., L. Bastin, J. Martinez Lopez, et al. 2015. The Digital Obsenatory for Protected Areas (DOPA) Explorer 1.O. European Commission, Joint Research Centre, Institute for Environment and Sustainability. <http://publications.jrc.ec.europa.eu/repository/bitstream/JRC95295/1b-na27162-en-n\%20.pdf/Accessed on 22 May, 2019>

Dudley, N. and S. Stolton 1999. Threats to Forest Protected Areas: A Survey of 10 Countries. Gland: IUCN.

Dudley, N. 2008. Lignes directrices pour l'application des catégories de gestion aux aires protégées. Gland: UICN.

Dudley, N., S. Stolton, A. Belokurov, et al. 2010. Natural Solutions: Protected Areas Helping People Cope with Climate Change. Gland, Washington, DC and New York: IUCN-WCPA, TNC, UNDP, WCS, World Bank, WWF.

Dumoulin, D.K. 2005. Les politiques de conservation de la nature en Amérique latine: Au cour de 
Gloriose Umuziranenge and Elysée Ntiranyibagira

l'internationalisation et de la convergence des ordres politiques. Genève and Paris: IUED-NCCR North-South, CREDAL, REVISTA DE LA CEPAL. Numéro Spécial: 71-85.

Dumoulin, D.K. and E. Rodary 2005. 'Les ONG, au centre du secteur mondial de la conservation de la biodiversité'. In Représenter la nature? ONG et biodiversité. Ed. Aubertin C, Paris: IRD Éditions, pp.59-98.

Emerton, L., J. Bishop, and L. Thomas 2006. Sustainable Financing of Protected Areas. A Global Review of Challenges and Options. Best Practice Protected Area Guidelines Series No.13. Gland: IUCN.

Ferraro, P.J. and A. Kiss 2002. 'Direct payment for conserving biodiversity'. Science 298: 1718-1719.

Ferraro, P. and D. Simpson 2003. 'Protecting forest and biodiversity: Are investments in eco-friendly production activities the best way to protect endangered ecosystems and enhance rural livelihoods?' Paper presented at the international conference on Rural Livelihoods, Forests and Biodiversity, 19-23 May 2003, Bonn, Germany.

Fonds pour 1'Environnement Mondial (FEM) 2010. Approche-Programme pour la présenvation de la biodiversité en Afrique de l'Ouest et en Afrique centrale.

Food and Agriculture Organization of the United Nations (FAO) 2012. Situation des forets du monde. Dixième édition.

Ghimire, K.B. and M.P Pimbert 1997. Social Change and Conservation. Genève: Earthscan.

Giraut, F., S. Guyot, and M. Houssay-Holzschuch 2004. 'Les aires protégées dans les recompositions territoriales africaines'. L'information géographique, Armand Colin, pp.340-368.

Granier, L. 2009. 'Participation des populations locales à la gestion des aires protégées et contribution à la lutte contre la pauvreté: de nouvelles solutions juridiques'.

$<$ http://www.ecocy.net/fr/journal.php?actu=29, 3p / Accessed on 15 March 2019>

Guéneau, S. and J. Franck 2004. 'Conservation de la biodiversité forestière tropicale en Afrique centrale: dépassionner les débats'. Institut du développement durable et des relations internationales. (Idées pour le débat $n^{\circ} 14 / 2005$ ).

Hannah, L. 1992. Afric an People, African Parks: An Evaluation of Development Initiatives as a Means of Improving Protected Conservation in Africa. Washington, DC: USAID.

Harroy, J.P. 1949. Afrique, terre qui meurt. La dégradation des sols africains sous l'influence de la colonisation. Bruxelles: Editions Marcel Hayez.

Hartley, A., A. Nelson, P. Mayaux, et al. 2007. The Assessment of African Protected Areas. A Characterization of Biodiversity Value, Ecosystems and Threats, to Inform the Effective Allocation of Conservation Funding. Luxembourg: Office for Official Publications of the European Communities.

Heemskerk, M. 2001. 'Book review: A. Wood, P. Stedman-Edwards, and J. Mang editors. 2000. The Root Causes of Biodiversity Loss. World Wildlife Fund and Earthscan Publications Ltd., London, 
UK'. Conservation Ecology 5(1): 12.

$<$ http://www.consecol.org/vol5/iss 1/art12/ Accessed on 15 February 2019>

Héritier, S. 2007. 'Les parcs nationaux entre conservation durable et développement local'. Géocarrefour $82 / 4$ | 2007.

$<$ http://geocarrefour.revues.org/2992, 6p / Accessed on 8 July 2019>

Hocking, M. and A. Phillips 1999. 'How well are we doing? Some thoughts on the effectiveness of protected areas'. Parks 9(2): 5-14.

Hockings, M., S. Stolton, F. Leverington, et al. 2006. Evaluating Effectiveness: A Framework for Assessing Management Effectiveness of Protected Areas Second Edition. $\mathrm{N}^{\circ} 14$. Gland: UICN.

Hopkins, J.J., H.M. Allison, C.A. Walmsley, et al. 2007. Conserving Biodiversity in a Changing Climate: Guidance on Building Capacity to Adapt. London: Department of Environment, Food and Rural Affairs.

Honloukou, A. 2014. Panvreté, communauté et État: Comprendre les enjeux stratégiques pour une meilleure gestion des aires protégées au Bénin.

Hugh, S. 2000. 'Aires protégées. Avantages sans frontières. La CMAP en action'. Gland: UICN/CMAP. Hughes, R.H. and J.S. Hughes 1992. Répertoire des zones humides d'Afrique. Gland: UICN/PNUE/CMSC.

Hulme, D. and M.W. Murphree (Eds.) 2001. African Wildlife and Livelihoods: The Promise and Performance of Community Conservation. Oxford: James Currey.

Huxley, J. 1961. The conservation of wildlife and natural habitats in Central and East Africa. Paris: UNESCO.

International Union for Conservation of Nature (IUCN) 1992. Protected Areas of the World: A Review of National Systems. Volume 3: Afrotropical. Gland: IUCN (Prepared by the World Conservation Monitoring Centre).

1999. Parks for Biodiversity: Policy Guidance Based on Experience in ACP Countries. Gland: IUCN (Prepared by the World Commission on Protected Areas $<$ WCPA $>$ of IUCN).

James, A.N. 1999. 'Institutional constraints on protected area funding'. Parks 9(2): 15-26.

Joliveau, T. (Dir.) 2001. 'Les territoires de la participation'. Géocarrefour 76(3): 171-280.

Kabore, A. 2010. 'Brousse des uns, aire protégée des autres. Histoire du peuplement, perceptions de la nature et politique des aires protégées dans le Gourmaburkinabè: 1'exemple de la Réserve partielle de faune de Pama'. Thèse de Doctorat. Institut de Hautes Etudes Internationales (Genève) et du Développement.

Kanyamibwa, S. 1998. 'Impact of war on conservation: Rwandan environment and wildife in agony'. Biodiversity and Conservation 7: 1399-1406.

Kasisi, R. 2012. 'Les perspectives de la biodiversité en Afrique subsaharienne : Repenser collectivement le modèle de gestion'. Vertigo-la revue électronique en sciences de l'environnement 12(2). 
$<$ http://vertigo.revues.org/12263; doi: 10.4000/vertigo.12263 / Accessed on 15 February 2019>

Katembo Vikanza, P. 2011. 'Aires protégées, espaces disputés et développement au nord-est de la R.D. Congo'. Thèse de Doctorat, Université Catholique de Louvain.

Koontz, A. 2008. The Conservation Marketing Equation. A Mamual for Conservation and Development Professionals. Enterprise Works/VITA, USAID.

Landreau, B. 2012. Guide pour l'élaboration des plans d'affaires simplifiés pour les aires protégées. Fédération Internationale du Banc d'Arquin, Agence Française pour le Développement, Fonds Français pour 1'Environnement Mondial.

Laslaz, L. 2010. 'Parcs nationaux de montagne et construction territoriale des processus participatifs'. Revue de géographie alpine/Journal of Alpine Research 98.

Locke, H. and P. Dearden 2005. 'Rethinking protected area categories and the new paradigm'. Environmental Consenation 32 (1): 1-10.

Mac Chapin 2004. 'A challenge to conservationists.'. World Watch 17(6): 17-31.

Mackinnon, J.K., G.C. Mackinnon, and J. Thorsell 1990. Aménagement et gestion des aires protégées tropicales. Gland: UICN.

Mahamadou, S.M.M and A. Boureima 2015. 'Indicateurs de mesure de la pression anthropique sur les ressources naturelles: Exemple de la périphérie du Parc «W» dans la commune rurale de Tamou au Niger'. Vertigo-la revue électronique en sciences de l'environnement 14(1).

$<$ http://vertigo.revues.org/14754 / Accessed on 15 February 2019>

Manuel, B. and C. Doumenge 2008. 'Entre marginalisation et démagogie: Quelle place reste-t-il pour les communautés locales dans les aires protégées?' Les Cahiers d'Outre-Mer 244, mis en ligne le 01 octobre 2011. doi: 10.4000/com.5476.

McCarty, J.P. 2001. 'Ecological consequences of recent climate change'. Conservation Biology 15: $320-331$.

MEA 2005. Rapport de synthèse de l'évaluation des écosystèmes pour le millénaire. Millenium Ecosystem Assessment.

Mengue-Medou, C. 2002. 'Les aires protégées en Afrique: perspectives pour leur conservation'. Vertigo- la revue électronique en sciences de l'environnement. 3(1).

$<$ http://vertigo.revues.org/index4 126.html / Accessed on 5 April 2019>

Montpetit, S. 2013. 'Les aires protégées transfrontalières: Au-delà de la conservation de la biodiversité.' Essai pour l'obtention du grade de Maîtrise en Ecologie intemationale, Université de Sherbrooke.

Myers, R., R.A. Mittermeier, C.G Mittermeier, G.A.B. Da Fonseca, and J. Kent 2000. 'Biodiversity hotspots for conservation priorities'. Nature 403: 853-858.

Ndemanou, R. 2012. 'La problématique de gestion des aires protégées en Afrique Centrale: Le cas du Parc national de la Lopé au Gabon'. Réseau ECOFAC.

Nelson, A. and K. Chomitz 2009. Protected area effectiveness in reducing tropical deforestation: $A$ 
global analysis of the impact of protection status. Evaluation Brief 7. Washington, DC: World Bank.

Nelson, J. and L. Hossack 2001. 'Indigenous peoples and protected areas in Africa: From principle to practice'. Forest Peoples Program.

Neumann, R.P. 1998. Imposing Wilderness: Struggles over Livelihood and Nature Preservation in Africa. Los Angeles and Berkeley: University of California Press.

Niang, C.I. 1990. 'Des crises écologiques en Occident au défi énergétique en Afrique'. Revue Internationale des Sciences Sociales 124 .

Nicholls, H. 2004. 'The conservation business', PLoSBiology 2 (9): 1256-1259.

Nouidemona, J.D 2004. 'La problématique des activités humaines dans les aires classées: Cas du Parc National du Delta du Saloum (Sénégal)'. Mémoire de DEA. Université Cheikh Anta Diop de Dakar, Institut des Sciences de 1'Environnement.

Ntiranyibagira, E. 2017. 'Dynamiques d'occupation du sol, tendances évolutives globales et facteurs d'evolution des aires protégées. Etude diachronique du Parc national périurbain de la Rusizi (Burundi) de 1984 à 2015'. These de Doctorat Unique en Sciences de 1'Environnement, Université Cheikh Anta Diop de Dakar (Senegal).

— 2019. 'Conceptual and analytic model for advanced evaluation of protected areas' global evolutionary trends: The protected areas' trends assessment and adaptive management on the basis of long-term conservation objectives or PA-TAMCO analytic model'. American Journal of Environmental Science and Engineering 3(1): 8-16. doi: 10.11648/j .ajese .20190301.12.

Ntiranyibagira, E., F.X. Naramabuye, T. Uwilingiyimana, F. Muhirwa, A. Kibogo, G. Umuziranenge, I. Kayumba, and C. Nsengumuremyi 2019. 'Design, characterization and geospatial analysis of physical and socio-economic indicators of anthropogenic pressures on protected areas in Africa'. International Journal of Environment and Climate Change 9(1): 44-57. doi: 10.9734/LJECC/2019/v9i130096.

Oates, J.F. 1999. Myth and Reality in the Rain Forest: How Conservation Strategies are Failing in West Africa. Berkley: University of California Press.

Ogunjobi, J.A., S.K. Halidu, B.R. Odebiyi, and I.J. Fxentirimam 2018. 'Crop raiding pattern of the African elephant (Loxodonta africana) in farms around Kamuku National Park, Nigeria'. African Journal of Agriculture Technology and Environment 7(2): 174-187.

Olson, D., E. Dinerstein, E. Wikramanayake, et al. 2001. 'Terrestrial ecoregions of the world: A new map of life on earth'. Bioscience 51: 933-938.

Olson, D.M. and E. Dinerstein 2002. 'The Global 200: Priority ecoregions for global conservation'. Annals of the Missouri Botanical Garden 89: 199-224.

Organisation for Economic Co-operation and Development (OECD) 1993. Core Set of Indicators for Environmental Performance Reviews. Paris: OCDE. 
$<$ http://www.virtualcentre.org/en/dec/toolbox/Refer/gd93179.pdf / Accessed on 15 February 2019>

Pèlerin, E., A. Mansion, and P. Lavigne Delville 2011. Afrique des Grands Lacs: Droit à la terre, droit à la paix. Des clés pour comprendre et agir sur la sécurisation foncière rurale. Coll. Études et Travaux, série en ligne $n^{\circ}$ 30. CCFD-Terre Solidaire / GRET.

Péron, X. 1995. L'occidentalisation des Maasaï du Kenya: Privatisation foncière et destruction sociale chez les Maasaï du Kenya. Paris: L'Harmattan.

Raffin, J.P. 2005. 'De la protection de la nature à la gouvernance de la biodiversité'. Ecologie et Politique 97-109.

Ramade, F. 1981. Ecologie des ressources naturelles. Paris: Masson.

Raven, P.H., L.R. Berg, and D.M. Hassenzahl 2008. Environment 6th Edition. Wiley: Edition De Boeck. Requier-Desjardins, M. 2012. Enjeux et modes d'intégration de la dimension socio-économique dans la surveillance environnementale. CIHEAM-IAMM, France, UMR MOISA / CSFD, Options méditerranéenes.

Ribot, J.C. and N.L. Peluso 2003. 'A theory of access'. Rural Sociology 68 (2): 153-181.

Rodary, E. 2001. 'Les espaces naturels: 1'aménagement par la participation? Mise en réseau et territorialisation des politiques de conservation de la faune en Zambie et au Zimbabwe'. Thèse de Doctorat, Université d'Orléans, France.

Rodary, E., C. Castellanet, and G. Rossi (Dir.) 2003. Conservation de la nature et développement. L'intégration impossible? Paris: Karthala.

Rossi, G. 2000. Ingérence écologique. Environnement et développement rural du nord au sud. Paris: CNRS Editions Coll. Espaces et Milieux.

2002. Ecologie du nord, paysans du sud: Environnement et développement rural. Paris: CNRS.

Rwanyiziri, G. 2002. 'Populations et aires protégées en Afrique de 1'Est (Burundi, Kenya, Ouganda, Rwanda, Tanzanie)'. Mémoire présenté à l'Université Michel de Montaigne-Bordeaux III en vue de 1'obtention de DEA en Géographie.

Rwanyiziri, G. 2009. 'Géopolitique de l'environnement au Rwanda. Pour une gouvernance participative des espaces protégés'. Université de Pau et des Pays de 1'Adour. Thèse de Doctorat. $<$ https://tel.archives-ouvertes.fr/tel-00449865 / Accessed on 25 March 2019>

Sambou, B. 2004. 'Evaluation de 1'état, de la dynamique et des tendances évolutives de la flore et de la végétation ligneuses dans les domaines soudanien et sub-guinéen au Sénégal'. Thèse de Doctorat d'Etat en Sciences Naturelles. Université Cheikh Anta Diop de Dakar.

Smith, J. 2013. Gestion et financement des aires protégées pour leur adaptation au changement climatique: Une analyse rapide des possibilités. UNEP-WCMC rapport technique.

Soulé, M.E. and J. Terborgh 1999. 'Conserving nature at regional and continental scales? A scientific program for North America'. Bioscience 49(10): 809-817.

\section{$-215-$}


Sournia, G. 1996. 'Les aires protégées d'Afrique francophone (Afrique centrale et occidentale). Hier, aujourd'hui, demain. Espaces à protéger ou espaces à partager?' Thèse de doctorat, Bordeaux, Université de Bordeaux III.

Tardif, G. 1999. Mesures à privilégier en bordure des aires protégées au Québec pour contribuer à l'atteinte de leurs objectifs. Gouvernement du Québec, Ministère des Ressources naturelles, Rapport d'Expertise.

Terborgh, J., C. Van Schai, L.C. Davenport, et al. (Eds.) 2002. Making Parks Work: Strategies for Preserving Tropical Nature. Washington, DC: Island Press.

Triplet, P. 2009. Manuel de gestion des aires protégées d'Afrique francophone. Paris: Awely. hal-00669157f

Turnbull, C. 1987. Les Iks: survivre par cruauté. Nord Ouganda. Paris: Plon/Terre humaine.

Union Internationale pour la Conservation de la Nature (UICN) 1994. Lignes directrices pour les catégories de gestion des aires protégées. Commission des parcs nationaux et des aires protégées de 1'Union mondiale pour la nature.

- 2004. Déclaration de Bangkok sur la gouvernance des ressources naturelles pour la consenvation et le développement durable. Bangkok.

- 2012. Cadre et outils d'évaluation de l'efficacité de la gestion des aires protégées en Afrique de l'ouest et du centre. Programme Afrique Centre et Ouest.

2014. Nouvelles des Aires Protégées en Afrique. 74.

UICN, PNUE, and WWF 1980. Stratégie mondiale de la consenation. La consenvation des ressources vivantes pour le développement durable. Gland: UICN.

UICN-PACO 2011. Parcs et réserves du Burundi: Evaluation de l'efficacité de gestion des aires protégées. Ouagadougou: UICN/PACO.

2012. Acteurs et gouvernance des aires protégées d'Afrique de l'Ouest: quelle contribution à la conservation? Ouagadougou: UICN/PACO.

Umuziranenge, G. 2019a. 'Parks' governance and management in Rwanda: Opportunities and challenges of the community participation for a sustainable conservation - Case study of Nyungwe National Park'. International Journal of Environmental Protection and Policy 7(2): 61-71. doi: 10.11648/j.ijepp.20190702.13.

2019b. 'Environmental justice and women empowerment in Nyungwe National Park (Rwanda): Case study of Kitabi Women Handcrafts Cooperative'. International Journal of Environment and Climate Change 9(2): 77-87. doi: 10.9734/ijecc/2019/v9i230098.

Veyret, Y. 2012. Dictionnaire de l'Environnement. Paris: Armand Colin.

Vives, M. 2001. 'Les aires protégées: un arc à plusieurs cordes'. Canopée 20.

Wanyingi, N.J. 2016. 'Determinants of human-elephant conflicts in shimba hills ecosystem, Kenya'. Doctoral dissertation. 
WCMC 1992. Tropical Managed Areas Assessment. Assessment the Conservation Status of the World

Tropical Forest: A Contribution to the FAO Forest Resources Assessment 1990. Cambridg WCMC.

Webber, A., C. Hill, and V. Reynolds 2007. 'Assessing the failure of a community-based human-wildli conflict mitigation project in Budongo Forest Reserve, Uganda'. Oryx 41: 177-84.

Weigel, F.Y., F. Féral, and B. Cazalet 2007. Les aires marines protégées d'Afrique de l'Oues Gouvernance et politiques publiques. Perpignan: Presses Universitaires de Perpignan.

Welch, D. 2005. 'What should protected area managers do in the face of climate change?' The Geor: Wright Forum 22(1): 75-93.

Wes, S., T.M. Brooks, G.A.B. Da Fonseca, et al. 2002. 'Hotspots and the conservation of evolutiona: history'. Proceedings of the National Academy of Sciences of the United States of America (PNA, 99(4): 2067-2071. doi: 10.1073/pnas.251680798.

Western, D. and M. Wright (Eds.) 1994. Natural Connections: Perspectives in Community-bast Conservation First Edition. Washington, DC: Island Press.

Williams, M. 2000. 'Dark ages and dark areas: Global deforestation in the deep past'. Journal Historical Geography 26: 28-46.

Wilson, K.E., M.F. McBride, M. Bode, and H.P. Possingham 2006. 'Prioritizing global conservatic efforts'. Nature 440(7082): 337-340.

WWF/BAD 2012. Rapport sur l'empreinte écologique de l'Afrique.

$<$ www.afdb.org / Accessed on 21 June 2019> 


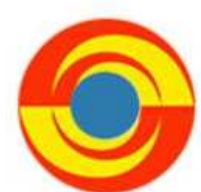

\section{International Journal of Environmental Protection and Policy (IJEPP)}

http://www.sciencepublishinggroup.com/j/ijepp

The Official Publication of Science Publishing Group

\section{Manuscript Review Form}

\section{Instructions to Reviewers:}

Please remember that all materials submitted for consideration to IJEPP are confidential, and should not be distributed, shared, used or otherwise supplied to third parties prior to publication.

Tell the Editors if there is any conflict of interest in reviewing of the paper.

Please phrase your reviews politely; even 'bad' papers represent a lot of work on the part of the authors. The review may be the basis for further revisions of the paper or the work that the paper reports. We all know how hurtful a needlessly negative review can be, and how helpful a positive one can be; please try to bear that in mind when you are writing yours. Meanwhile the author will give a feedback of the reviewer's evaluation to the Editors. It provides the evidence for Editors to decide whether the reviewer is qualified.

Please respond within the allotted time so that we can give the authors timely responses and feedback.

\begin{tabular}{|l|l|l|}
\hline Manuscript Number: & IJEPP_2661136_20190226 \\
\hline Article Title: & $\begin{array}{l}\text { Parks' Governance and Management in Rwanda: Opportunities and Challenges of the } \\
\text { Community Participation for a Sustainable Conservation. Case Study of Nyungwe National } \\
\text { Park }\end{array}$ \\
\hline
\end{tabular}

\section{Answer the 3 Questions Below:}

\section{Questions}

\section{Does the purpose or purported significance of the article state explicitly?}

\section{YES}

2. Is the significance of the paper explained relative to provious work?

YES

3. Is the paper clearly witten and well organized? 


\section{International Journal of Environmental Protection and Policy (IJEPP) Manuscript Review Form}

Note that these comments may be in addition to or in lieu of reviewer comments inserted into the text of the article. Use as many lines as needed.

a) Please give a frenk account of the strengths and weaknesses of the article (in 100-200 words):

This is a carefully done study. It is clearly written and well organized. However, there are still many obvious problems in this paper. It is suggested that the author revise this article carefully according to the relevant opinions.

b) Please provide detailed suggestions on how to improve the paper (in 100-200 words):

-Main problems of the article (e.g. Methodology, Interpretation)

-In order of seriousness/relevance

1. If the affiliations of all authors are the same, the author's superscript is not required. Besides, the author's affiliation only needs to remain one and does not need to be numbered. Please check and delete.

2. Based on the publishing standards, the corresponding reference should be marked in the corresponding position in the main body in form of [] (such as: [1], [2], [3] ...) instead of other forms (such as: "(Adams and al, 2003)"). Please revise carefully in the whole article.

3. The introduction is suggested to be presented in several paragraphs to make the structure more clear.

c) Minor corrments (if any)

-Missing references, Stylistic problems, Typos, Misleading Captions, etc.

1. In view of the publishing standards, the period is not allowed at the end of the title, so we delete it. Please check and confirm.

2. Usually the number of words in the title of the paper should be at least 7 words but no more than 25 words. Please check and revise.

3. According to the publishing standards, the affiliations of all authors should only include department/faculty, university/institute, city and country. Such as:

Dhirajkumar Davie ${ }^{1}$, Linda Luvai ${ }^{2}$

${ }^{1}$ Department of Accounting \& Finance, North South University, Dhaka, Bangladesh

${ }^{2}$ Department of Metallurgical and Materials Engineering, Yerevan State University, Yerevan, Armenia

Please check and revise.

Please check and delete unneeded information.

4. Based on the publishing standards, the "Abstract:" should be added before the abstract.

5. To meet the publishing standards, references in the Reference list should be numbered like "[1], [2], [3]..." rather than " $1,2,3 \ldots$ " Please check and revise.

\section{Confidential Comments (if any):}

Note that any comments in this section will not be shown to the authors.

Authors' Feedback of Reviewer's Work to SciencePG

Specific eveluation to the Reviewer's review result

Rating Result 


\section{International Journal of Environmental Protection and Policy (IJEPP)}

Manuscript Review Form

\begin{tabular}{|l|l|}
\hline & [Poor] 1-5 [Excellent] \\
\hline & \\
\hline
\end{tabular}


APPENDIX G: Paper 2 Review

SCIENCEDOMAIN international www.sciencedomaninorg

SDI Review Form 1.6

\begin{tabular}{|l|l|}
\hline Journal Name: & International Journal of Environment and Climate Change \\
\hline Manuscript Number: & Ms_JJEC__48394 \\
\hline Title of the Manuscript: & Environmental Justice and Women Empowerment in Nyungwe National Park (Rwanda): Case Study of Kitabi Women Handcratts Cooperative \\
\hline Type of the Article & Original Research Article \\
\hline
\end{tabular}

\section{General guideline for Peer Review process:}

This journal's peer review policy states that № manuscript should be rejected only on the basis of 'Iack of Noveltv', provided the manuscript is scientifically pobust and technically sound.

To know the complete guideline for Peer Review process, evevewers are requested to visit this link:

(http:Ilwww.sciencedomain.ordpagelsdi-general-edilorial-policy)

PART 1: Review Comments

\begin{tabular}{|l|l|l|}
\hline & Reviewer's comment & $\begin{array}{l}\text { Author's comment (fi agreed with reviewer, correct the manuscript and } \\
\text { highlight that part in the manuscript. It is mandatory that authors should write } \\
\text { hisher feedback here) }\end{array}$ \\
\hline Compulsory REVISION comments & & \\
\hline Minor REVISION comments & $\begin{array}{l}\text { Based on the extensiveness of literary satements, the introduction could be divided into } \\
\text { two chapters: an introduction" and a "literary revew". }\end{array}$ & \\
\hline Optional/General comments & & \\
\hline
\end{tabular}

PART 2:

\begin{tabular}{|l|l|l|}
\hline & Reviewer's comment & $\begin{array}{l}\text { Author's comment (if agreed with reviewer, correct the manuscript and } \\
\text { hightight that part in the manuscript. It is mandatory that authors should wrte } \\
\text { hishher feedback here) }\end{array}$ \\
\hline Are there ethical issues in this manuscript? & (If ves. Kindly please write down the ethical issues here in detalils) & \\
\hline
\end{tabular}

\section{Reviewer Details:}

\begin{tabular}{|l|l|}
\hline Name: & Borislav Kolaric \\
\hline Department, University \& Country & University Union - Nikola Tesla , Serbia \\
\hline
\end{tabular}

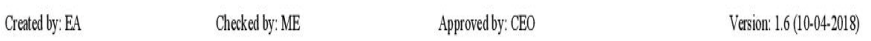


SCIENCEDOMAIN international

ww. sciencedomain. org

$\underline{\text { SDI Review Form } 1.6}$

\begin{tabular}{|l|l|}
\hline Journal Name: & International Journal of Environment and Climate Change \\
\hline Manuscript Number: & Ms_JEECC__8394 \\
\hline Title of the Manuscript: & Environmental Justice and Women Empowerment in Nyungwe National Park (Rwanda): Case Study of Kitabi Women Handcrafts Cooperative \\
\hline Type of the Article & Original Research Article \\
\hline
\end{tabular}

\section{General guideline for Peer Review process:}

This journal's peer review policy states that № manuscript should be rejected only on the basis of 'lack of Novelty', provided the manuscriptis scientifically robust and technically sound To know the complete guideline for Peer Review process, reviewers are requested to visit this link:

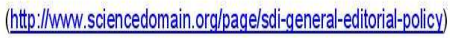

\section{PART 1: Review Comments}

\begin{tabular}{|c|c|c|}
\hline & Reviewer's comment & $\begin{array}{l}\text { Author's comment (ff agreed with reviewer, correct the manuscript and } \\
\text { highlight that part in the manuscript. It is mandatory that authors should write } \\
\text { hishher feedback here) }\end{array}$ \\
\hline Compulsory REVISION comments & $\begin{array}{l}\text { A good empirical research study very much fit for publication by IJECC. } \\
\text { However, the study has one major shortcoming which has completely watered down } \\
\text { the findings of the paper. This flaw is "sample size". The sample size of the study is } \\
\text { too small (Just } 12 \text { persons). This small sample size does not permit the the study to } \\
\text { draw conclusions based on the general population. Thus, based on the present } \\
\text { sample size, the findings of the study can not be considered as very relevant owing } \\
\text { to the smallness of the sample size. The author(s) of the study should therefore } \\
\text { undertake the research again and increase the sample size to above } 60 \text { persons, in } \\
\text { order to make the findings of the study more relevant and scientifically robust. }\end{array}$ & \\
\hline \multicolumn{3}{|l|}{ Minor REVISION comments } \\
\hline Optional/General comments & $\begin{array}{l}\text { Good empirical research study fit for publication by IJECC. However, the sample size } \\
\text { needs to be looked into again and findings of the paper corrected before the paper can be } \\
\text { considered for publication. }\end{array}$ & \\
\hline
\end{tabular}

\section{PART 2:}

\begin{tabular}{|l|l|l|}
\hline & Reviewer's comment & $\begin{array}{l}\text { Author's comment (if agreed with reviewer, correct the manuscript and } \\
\text { highlight that part in the manuscript. It is mandatory that authors should write } \\
\text { hishther feedback here) }\end{array}$ \\
\hline Are there ethical issues in this manuscript? & (ff ves, Kindly please write down the ethical issues here in detalils) & \\
\hline
\end{tabular}

\section{Reviewer Details:}

\begin{tabular}{|l|l|}
\hline Name: & Nyong Princely Awazi \\
\hline Department, University \& Country & University of Dschang, Cameroon \\
\hline
\end{tabular}
Created by: EA 


\begin{tabular}{|c|c|}
\hline & $\begin{array}{l}\text { ENCEDOMAIN international } \\
\text { ww. sclencedomanainorg }\end{array}$ \\
\hline Journal Name: & International Journal of Environment and Climate Change \\
\hline Manuscript Number: & Ms_IJECC_48394 \\
\hline Title of the Manuscript: & Environmental Justice and Women Empowerment in Nyungwe National Park (Rwanda): Case Study of Kitabi Women Handcrafts Cooperative \\
\hline Type of the Article & Original Research Article \\
\hline
\end{tabular}

General quideline for Peer Review process:

This journal's peer review policy states that № manuscript should be rejected only on the basis of 'lack of Novelty', provided the manuscript is scientifically robust and technically sound. To know the complete guideline for Peer Review process, reviewers are requested to visit this link:

(htp://uww.sciencedomain.org/page/sdi-general-editorial-policy)

PART 1: Review Comments

\begin{tabular}{|l|l|l|}
\hline & Reviewer's comment & $\begin{array}{l}\text { Author's comment (ff agreed with reviewer, correct the manuscript and } \\
\text { highlight that part in the manuscript. It is mandatory that authors should write } \\
\text { hisher feedback here) }\end{array}$ \\
\hline Compulsory REVISION comments & & \\
\hline Minor REVISION comments & If author introduce some photographs of the national park, its good for the paper. & \\
\hline Optional/General comments & & \\
\hline
\end{tabular}

PART 2:

\begin{tabular}{|l|l|l|}
\hline & Reviewer's comment & $\begin{array}{l}\text { Author's comment (if agreed with reviewer, correct the manuscript and } \\
\text { highlight that part in the manuscript. It is mandatory that authors should write } \\
\text { his/her feedback here) }\end{array}$ \\
\hline Are there ethical issues in this manuscript? & (If yes, Kindly please write down the ethical issues here in details) & \\
\hline
\end{tabular}

\section{Reviewer Details:}

\begin{tabular}{|l|l|}
\hline Name: & Vartika Singh \\
\hline Dapant
\end{tabular}

\begin{tabular}{|l|l|}
\hline Name: & Vartika Singh \\
\hline Department, University \& Country & Amity University, India \\
\hline
\end{tabular}

Created by: EA Checked by: ME Approved by: CE0 Vesion 1.6(10-04-2018) 


\title{
APPENDIX H: Paper 4 Review
}
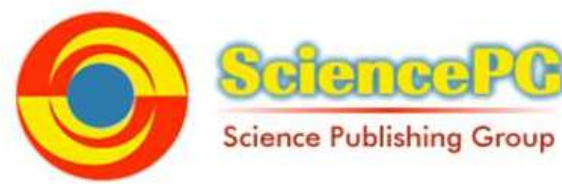 \\ Science Publishing Group

\section{International Journal of Natural Resource Ecology and Management (IJNREM) \\ http://www.sciencepublishinggroup.com/j/ijnrem \\ The Official Publication of Science Publishing Group}

\section{Manuscript Review Form}

\section{Instructions to Reviewers:}

Please remember that all materials submitted for consideration to IJNREMare confidential, and should not be distributed, shared, used or otherwisesupplied to third parties prior to publication.

Tell the Editors if there is any conflict of interest in reviewing of thepaper.

Please phrase your reviews politely; even 'bad' papers represent a lot of work on the part of the authors. The review may be the basis for further revisions of the paper or the work that the paper reports. We all know how hurtful a needlessly negative review can be, and how helpful a positive one can be; please try to bear that in mind when you are writing yours.Meanwhile the author will give a feedback of the reviewer's evaluation to the Editors. It provides the evidence for Editors to decide whether the reviewer is qualified.

Please respond within the allotted time so that we can give the authorstimely responses and feedback.

\begin{tabular}{|l|l|l|}
\hline \multicolumn{2}{|l|}{ Manuscript Number: } & IJNREM_2071098_20190819 \\
\hline Article Title: & $\begin{array}{l}\text { Community Perceptions of Human-wildlife Conflicts and the Compensation Scheme around } \\
\text { Nyungwe National Park (Rwenda) }\end{array}$ \\
\hline
\end{tabular}

\section{Answer the 3 Questions Below:}

\section{Questions}

1. Does the purpose or purported significance of the articlestate explicitly?

YES

2. Is the significance of the paper explained relative to previous work?

YES

3. Is the peper clearly written and well orgarized?

YES 


\section{International Journal of Natural Resource Ecology and Management (IJNREM) \\ Manuscript Review Form}

\section{Specific Reviewer Comments and Suggestions:}

Note that these comments may be in addition to or in lieu of reviewer comments inserted into the text of the article. Use as many lines as needed.

\section{a) Ploase give a trank account of the strengths and weaknesses of the article (in 100-200 words):}

In this paper, the author gives a detailed analysis of Community Perceptions of Human-wildlife Conflicts and the Compensation Scheme Around Nyungwe National Park (Rwanda). Obviously the author has done sufficient work on this topic. The paper is organized logically and structured clearly. The purpose and significance of the study are clearly stated, and research method is appropriate. Besides, the results are presented explicitly by the tables and figures and the author gives a comprehensive analysis in discussion. However, there are still some parts which need to be modified in the paper. The author is suggested to make some revisions so that the paper will be better.

b) Please provide detailed suggestions on how to improve the paper (in 100-200 words):

-Main problems of the article (e.g. Methodology, Interpretation)

-In order of seriousness/relevance

1. Some parts of the article can be given a further analysis, such as the part of "Research methods and data". Then the quality of the article will be improved.

2. The English of this manuscript need be checked and improved.

c) Minor comments (if any)

-Missing references, Stylistic problems, Typos, Misleading Captions, etc.

1. The information of your affiliated unit should include 4 parts "Department/Faculty, University/Institute, City, Country". For example:

Harvard Business School, Harvard University, Cambridge, the United States

【单位信息(公司)包括 3 部分】The information of your affiliated unit should include 3 parts "Company,

City, Country". For example:

Apple Inc., Cupertino, the United States

2. Figure 2 is a combination of several pictures. Please replace it with a complete one. Screenshot is suggested.

\section{Confidential Comments (if any):}

Note that any comments in this section will not be shown to the authors.

\section{Authors' FeedbackofReviewer's Work to SciencePG}

$$
\text { Specific evaluation to the Reviewer's review result }
$$

Rating Result

[Poor] 1-5 [Excellent] 


\section{APPENDIX I: Paper 5 Review}

September 15, 2020

Evaluation and publishing process of the paper titled "Nature conservation policies and practices in Africa: Critical analysis, ideological challenges and strategic vision for protected areas sustainable management", written by Gloriose Umuziranenge and Elysée Ntiranyibagira.

To whom it may concern,

Responding to the call-for-paper for the publication of the African Studies Center - Tokyo University of Foreign Studies, this paper was submitted in November 2019. One of the authors (Ms. Gloriose Umuziranenge) presented it in the PIASS-TUFS international conference held in Huye, Rwanda, in February 2020.

In this paper, the authors give a detailed analysis of Nature conservation policies and practices in Africa. The paper is clearly written and well organized, and its purpose and research method are suitable. We judged it a carefully done study. The paper was published in March 2020 in the ASC-TUFS working papers after an open review.

Shinichi Takeuchi

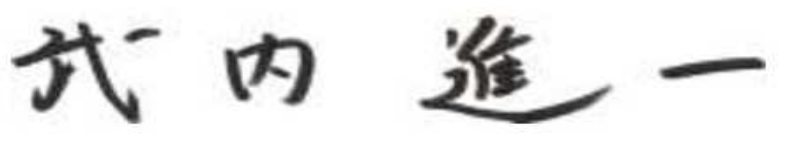

Director, Professor

African Studies Center,

Tokyo University of Foreign Studies

3-11-1, Asahicho,

Fuchu-shi, Tokyo,

183-8534, Japan

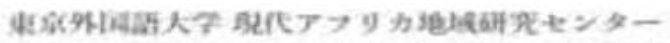

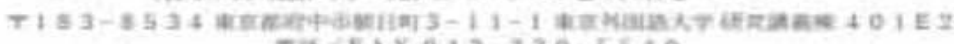

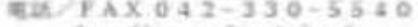

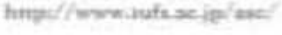




\title{
APPENDIX J: Conference Participation
}

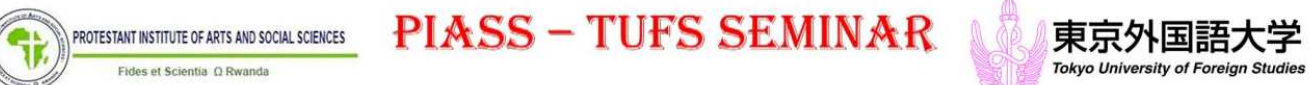 \\ Certificate of Attendance}

\author{
This is to certify that \\ Gloriose Umuziranenge \\ participated with a presentation entitled \\ Nature Conservation Policies and Practices in Africa: Critical Analysis, \\ $\underline{\text { Ideological Challenges and Strategic Vision for Protected Areas Sustainable Management }}$ \\ (with Elysée Ntiranyibagira) \\ in PIASS-TUFS Seminar
}

on 18-19 February, 2020 at Protestant Institute of Arts and Social Sciences, Rwanda.

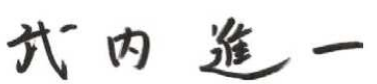

Prof. Shinichi Takeuchi

Director, African Studies Center,

Tokyo University of Foreign Studies

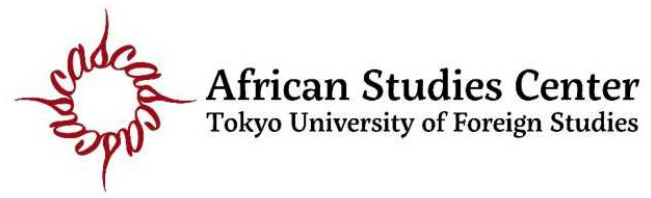




\section{Certificate of Participation}

\section{INTERNATIONAL CONFERENCE \\ AFricA-ASIA \\ A NEW AXIS OF KNOWLEDGE 2}

22 September 2018
Dar es Salaam, Tanzania

This is to certify that Gloriose Umuziranenge has presented a paper titled A Gender Perspective on Environmental Justice in Rwanda: Case Study of Protected Areas of Nyungwe National Park in the panel Resource Management and Political Power in Rural Africa. She also participated in the roundtable Resource Management and Political Power:

Comparison Between Africa and Asia. The Africa-Asia conference was held at the University of Dar es Salaam, Tanzania from 20-22 September 2018.

The conference has been organised by the University of Dar es Salaam (UDSM, Tanzania); Association for Asian Studies in Africa (A-ASIA, Ghana); International Institute for Asian Studies (IIAS, the Netherlands); and the International Convention of Asia Scholars (ICAS, the Netherlands).

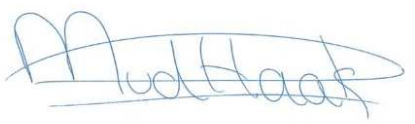

Ms Martina van den Haak

IIAS Seminar Coordinator/ICAS Executive Officer 


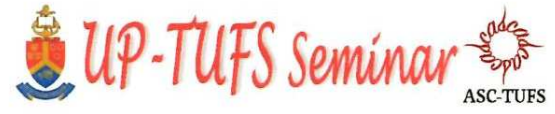 \\ Certificate of Attendance}

This is to certify that

\section{Gloriose Umuziranenge}

participated with a presentation entitled

Achieving Environmental Justice through Women Empowerment:

The Case of Women Handcraft Association in Kitabi Sector

in UP्P $T$ FS Seminar

on 13-14 September, 2018 at Vniversity of Pretoria, South Africa.
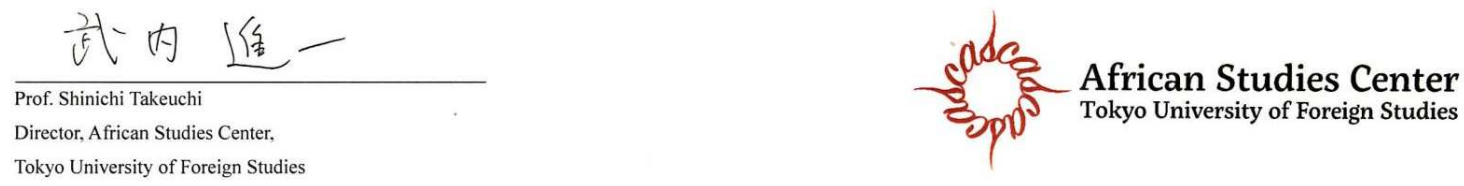


\section{APPENDIX K: Research Permit}

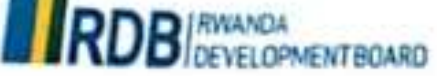

\section{RESEARCH CONTRACT}

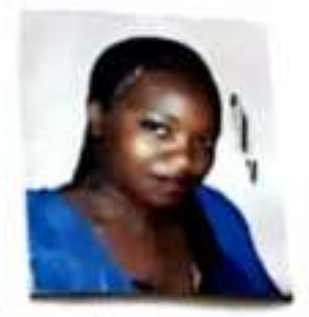

This agreement is made between the fwanda Development Board (RDB) Tourism 8 Conservation (hereinafter referred to as "the board") on one part and

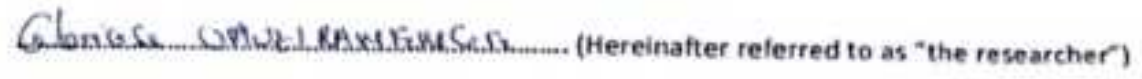

WHEREAS the researcher is the desirous of carrying out the research in the authority's protected area

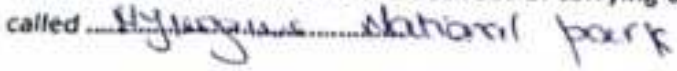

And WHEREAS the authority has agreed to the said research to be carried out in the said protected areas, under the terms and conditions herein stipulated,

IT IS NOW AGREED AS FOLLOWS:

1. The authority has authorized and allowed the researcher to carry out the research described herein below, in ...Abryan.

2. The research shall be restricted to (project title)

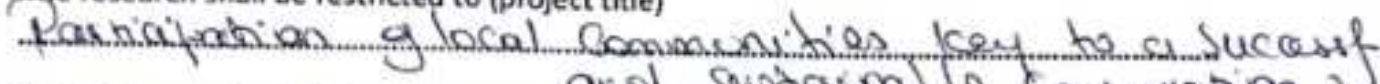
and Sidiarnable Convervation b'

3. The said research shall be commenced one days after execution of this agreement and shall have a duration of ..........months after which the said research shall cease to be carried out,

4. The researcher or the group of researchers as Foreign Citizen will pay the research application project fee of $50 \$$ nonrefundable paid once as consideration for the permission to carry out the research above described.

5. The researcher as a Foreign students will pay the research application project fee of $30 \$$ nonrefundable paid once as consideration for the permission to carry out the research above described.

6. Each of the researchers as Foreign Citizen shall pay $120 \$$ monthly research fee non refundable

7. Each of the researchers as Foreign Student shall pay $50 \$$ monthly research fee non refundable

8. The researcher or the group of researchers as Rwandan Citizen shall pay $\mathbf{5 0 0 0}$ Rwf monthly research fee nonrefundable and 5000 Rwf of application paid once.

9. Each of the researchers as Rwandan Students who is doing undergraduate courses shall pay 5000 Rwf of application. 